Neuma Rúbia Figueiredo Santana

(Organizadora)

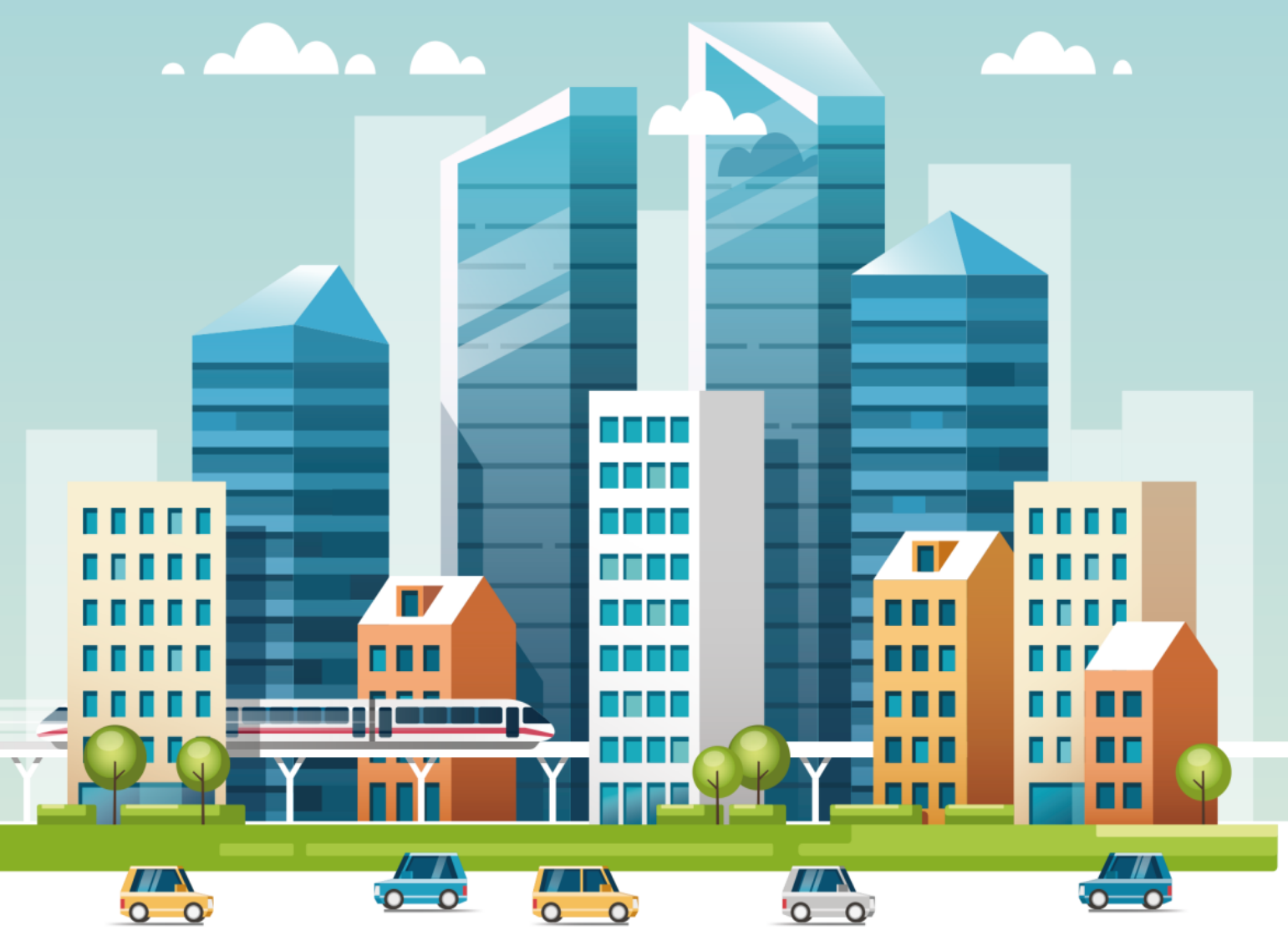

DIVERSOS ENSAIOS NA ENGENHARIA CIVIL no contexto sergipano 
Neuma Rúbia Figueiredo Santana

(Organizadora)

\section{Diversos Ensaios na Engenharia Civil no contexto sergipano}

1a Edição

Belo Horizonte

Poisson

2019 
Editor Chefe: Dr. Darly Fernando Andrade

\section{Conselho Editorial}

Dr. Antônio Artur de Souza - Universidade Federal de Minas Gerais

Ms. Davilson Eduardo Andrade

Dr. José Eduardo Ferreira Lopes - Universidade Federal de Uberlândia

Dr. Otaviano Francisco Neves - Pontifícia Universidade Católica de Minas Gerais

Dr. Luiz Cláudio de Lima - Universidade FUMEC

Dr. Nelson Ferreira Filho - Faculdades Kennedy

Ms. Valdiney Alves de Oliveira - Universidade Federal de Uberlândia

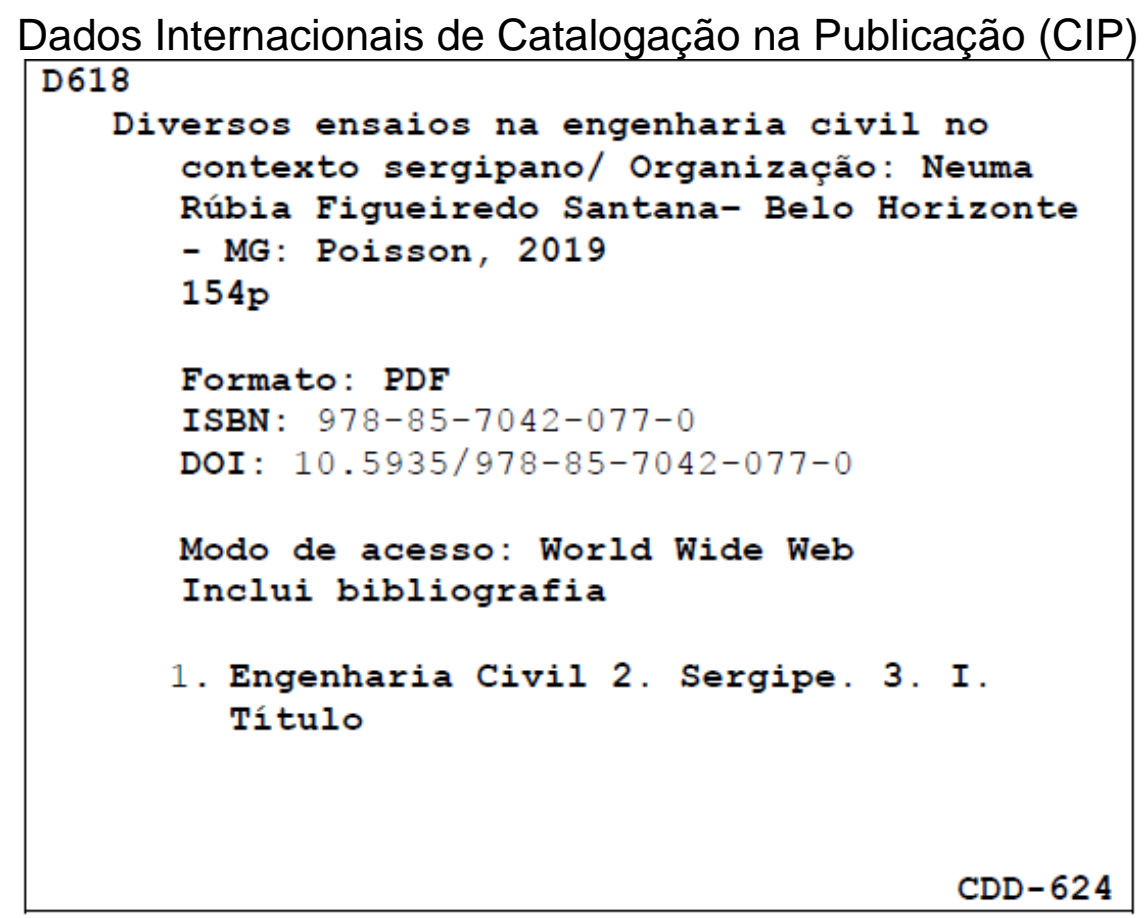

O conteúdo dos artigos e seus dados em sua forma, correção e confiabilidade são de responsabilidade exclusiva dos seus respectivos autores.

Baixe outros títulos gratuitamente em www.poisson.com.br contato@poisson.com.br 
Através da disciplina de trabalho de conclusão de curso os alunos têm a oportunidade de desenvolver uma visão crítica sobre os temas atuais da construção civil no estado de Sergipe permitindo uma aproximação prática e teórica dos assuntos vividos ao longo dos semestres. Os trabalhos apresentados neste E-Book foram decorrentes desta busca de conhecimento técnico cientifico envolvendo professores e alunos no último semestre do curso. Isto por que entendemos que 0 engenheiro Civil atua na supervisão, coordenação técnica, elaboração de projetos e execução, manutenção, recuperação de obras de construção civil e pesquisa.

Sandro lury Valverde Lima da Cruz

(Coordenador do curso)

Almir Querino de Melo

(Coordenador Adjunto)

Neuma Rúbia Figueiredo Santana

(Presidente do NDE)

\section{Prefácio}

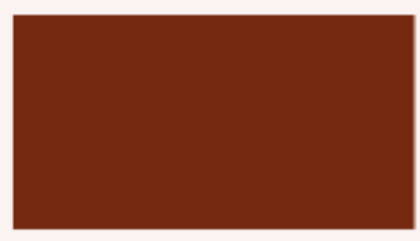




\section{SUMÁRIO}

CAPÍTULO 1: SIMULAÇÃO BASEADA EM SISTEMAS DINÂMICOS PARA A MODELAGEM DE CENÁRIOS SOBRE O GERENCIAMENTO DE RESÍDUOS DA CONSTRUÇÃO E

DEMOLIÇÃO EM ARACAJU.

PRISCILA CONCEIÇ̃̃̃O DE SOUZA

Silvio Leonardo VALEnÇa

CAPÍTULO 2: MICRODRENAGEM SUSTENTÁVEL: AVALIAÇÃO DO ESCOAMENTO SUPERFICIAL URBANO NO MUNICÍPIO DE ARACAJU/SE .

ÉRICA DE SOUZA VIANA

NEUMA RÚBia FIgUEIREDo SANTANA

CAPÍTULO 3: MANIFESTAÇÃO PATÓLOGICA DE CORROSÃO EM ESTRUTURA METÁLICA DE QUADRAS POLIESPORTIVAS DE ESCOLAS PÚBLICAS ESTADUAIS DA CIDADE DE ARACAJU

AnNA CARla DE JESUS SANTOS

ANA ANGÉliCA Dos SANTOS FARO

CAPÍTULO 4: SUBSTITUIÇÃO DOS AGREGADOS NATURAIS POR AGREGADOS RECICLADOS EM CONCRETO ESTRUTURAL

RAFAELla LiMA CORREIA

GISELI BARBOSA DE LIMA

CAPÍTULO 5: AUTOMATIZAÇÃO DO PROCESSO DE CATALOGAÇÃO DAS ORIGENS DE MANIFESTAÇÕES PATOLÓGICAS, EM ESPECIAL FISSURAS

LANA Laís PEREIRA DA CRUZ

ROMÁRIO DE JESUS SANTOS

CAPÍTULO 6: MANIFESTAÇÕES PATOLÓGICAS NO TERMINAL RODOVIÁRIO GOVERNADOR LUIZ GARCIA (RODOVIÁRIA VELHA)

HORTÊNCIA IRYS RIBEIRO LÚCIO

LUCIANA GOMES MaChADO NASCIMENTO

CAPÍTULO 7: INSPEÇÃO DE ESPAÇOS PÚBLICOS URBANOS LOCALIZADOS EM REGIÃO LITORÂNEA DE ARACAJU/SE ACOMETIDOS POR MANIFESTAÇÕES PATOLÓGICAS DE CORROSÃO.

Claryssa de Oliveira Barros

ANA ANGÉLICA DOS SANTOS FARO 


\section{SUMÁRIO}

CAPÍTULO 8: MÉTODOS INVESTIGATIVOS DO SUBSOLO PARA DIMENSIONAMENTO DE FUNDAÇÕES DE EDIFICAÇÕES DE BAIXO CUSTO. 95

JAILTON VieIRA DOS SANTOS NETO

CAPÍTULO 9: ANÁLISE DA APLICAÇÃO DA IMPRESSÃO 3D NA CONSTRUÇÃO CIVIL

JOYCE HELlY DA ANUNCIAÇÃo SOARES

JORGE EDUARDo FONTES LEITE

CAPÍTULO 10: ANÁLISE SOBRE A IMPLANTAÇ̃̃O DE FERRAMENTAS DE GESTÃO DE RISCOS EM OBRAS DE EDIFICAÇÕES NOS MUNICÍPIOS DE ARACAJU E SÃO CRISTÓVÃO/SE

Marcos Moran OliveIRA DA SILVA

SANDRO IURY VALVERDE LIMA DA CRUZ

AUTORES: 


\section{Capítulo 1}

\section{Simulação baseada em sistemas dinâmicos para a modelagem de cenários sobre o gerenciamento de resíduos da construção e demolição em Aracaju}

\section{Priscila Conceição de Souza}

Silvio Leonardo Valença

Resumo: Em razão do grande consumo de recursos naturais pela construção civil, assim como o alto índice de desperdício e os problemas ambientais atrelados ao processo de construção e demolição, se faz necessário um estudo sobre o gerenciamento desses resíduos no município de Aracaju com base em modelagem de cenários a partir do conceito de sistemas dinâmicos, com uso da ferramenta Vensim, afim de se obter dados que demonstrem a importância de uma mudança de paradigma na forma de tratar esses materiais desde a etapa de projetos, passando por todo o ciclo de vida da construção até a sua possível demolição. Dessa forma, fez-se uma pesquisa bibliográfica sobre o assunto, afim de obter dados históricos para realização de modelagem de cenários. Com isso, verifica-se que Aracaju possui um grande número de pontos de descarte ilegal de resíduos da construção e demolição que ocasionam problemas de natureza ambiental, social e econômica, uma vez que esses materiais, quando dispostos incorretamente, interrompem a drenagem fluvial do local, estimulam a geração de vetores de doenças, aumentam os problemas sociais, causam despesas para o município, além da perda do valor atrelado ao material descartado. Com isso, verifica-se que diante da problemática, uma análise de cenário é necessária para auxiliar nas tomadas de decisões que mitiguem os riscos oriundos da geração e gerenciamento incorreto desses materiais.

Palavras-chave: Resíduos da construção e demolição. Gerenciamento de resíduos. Sistemas dinâmicos. 


\section{INTRODUÇÃO}

A engenharia civil sempre esteve presente no desenvolvimento da nossa civilização, assim como acompanhou e incrementou conhecimentos adquiridos, beneficiando e aprimorando suas tecnologias e materiais. Dessa forma, temos a engenharia civil como fomentadora da ciência e como uma das principais atividades de uma nação que mostra traços da sua história e seu nível de desenvolvimento. Tendo em mente a sua importância vemos que as atividades atreladas devem ser sumariamente estudadas e beneficiadas a ponto de aprimorar técnicas e desenvolver melhorias na área. Segundo IBGE (2017), em 2016 a construção civil foi responsável por 5,6\% do Produto Interno Bruto (PIB) brasileiro. Além de rentável é uma atividade que mais consome recursos naturais.

De acordo com Lauriano (2013), o setor da construção no Brasil consome cerca de 75\% dos recursos naturais e $44 \%$ da energia produzida, resultando em $40 \%$ dos resíduos totais produzidos. Esse consumo representa $9 \%$ do total das emissões de $\mathrm{CO}^{2}$ emitidos pela atividade humana, acarretando em um maior número de problemas de natureza ambiental, sanitário e social. Os impactos ambientais estão presentes em todas as etapas do processo que vai desde a extração dos materiais, processamento, transporte, construção e continua durante a vida útil do empreendimento com os gastos energéticos e manutenções, até a sua demolição.

Recentemente a construção sustentável começou a ser discutida em reuniões que debatem as questões sobre meio ambiente como a Agenda 21, que é uma ferramenta que tem o objetivo de planejar o desenvolvimento sustentável e concilia métodos de proteção ambiental, justiça social e eficiência econômica (MMA, 2018). Assim como a publicação da Resolução do CONAMA no307 (2002) foi um grande marco na área de gerenciamento dos resíduos da construção, que dispõe sobre critérios, diretrizes e procedimentos para a gestão dos resíduos da construção.

Os números demonstram uma necessidade de realizar políticas de gestão mais efetivas assim como o gerenciamento desses materiais no canteiro de obra, voltada para um melhor aproveitamento e preocupação com a disposição final dos resíduos descartados. Diante da facilidade que existe e da pouca ou falta de fiscalização muitos geradores optam por descartar os resíduos em locais inapropriados sem custos de penalidades. Essas ações geram grande incômodo para a população que se encontram no entorno, sem falar no desperdício causado. Falta uma visão mais abrangente da situação por parte dos construtores de tratar esses resíduos como potencial material de uso na construção. A falta de gerenciamento desse tipo de resíduo leva ao descarte inapropriado e disposição clandestina em terrenos baldios, margens de rio e beira de estradas.

Para uma melhor compreensão dos problemas causados pelo gerenciamento incorreto dos resíduos da construção, o presente trabalho tem o objetivo de apresentar a problemática a partir de uma visão a longo prazo, realizando simulação de cenários, que nos permite ter uma visão aprofundada sobre o assunto e reforçar uma mudança de paradigma sobre a forma atual de como estamos lidando com o problema, que hoje pode parecer pequeno, mas pode se agravar futuramente.

\section{METODOLOGIA}

A pesquisa busca apresentar um estudo sobre o cenário do Gerenciamento dos Resíduos da Construção Civil em Aracaju a partir de modelagem computacional avaliando dois cenários, quando o gerenciamento é ideal e o gerenciamento real. Para tanto será utilizado o método de modelagem Sistemas Dinâmicos com o auxílio do programa Vensim. 0 estudo possui caráter meramente descritivo, pois o que se pretende é contribuir trazendo uma visão sobre um assunto que já está presente na realidade de trabalho da construção civil.

O tema será tratado qualitativamente e quantitativamente, trazendo observações e análises propostas pelo autor de forma a gerar debates futuros sobre a problemática, assim como estimular a busca por melhorias incitada pela visão proposta.

Os procedimentos adotados para a construção da pesquisa consistem em uma investigação bibliográfica do assunto, tendo como fontes livros, artigos e textos de caráter científico e um estudo de caso através da coleta de dados sobre a coleta de RCD em Aracaju pela EMSURB, buscando sempre trabalhar com dados que representem o mais fiel possível o cenário do município de Aracaju. 


\section{1 ÁREA DE ESTUDO}

A pesquisa será voltada para o município de Aracaju - SE (figura 01), localizado na região do litoral do estado e cortado pelos rios Sergipe, Poxim, Vaza barris e do Sal. A cidade faz parte da Região Metropolitana de Aracaju, a qual compreende outros municípios como Barra do Coqueiros, Nossa Senhora do Socorro e São Cristóvão.

Figura 01: Mapa de localização da área de estudo

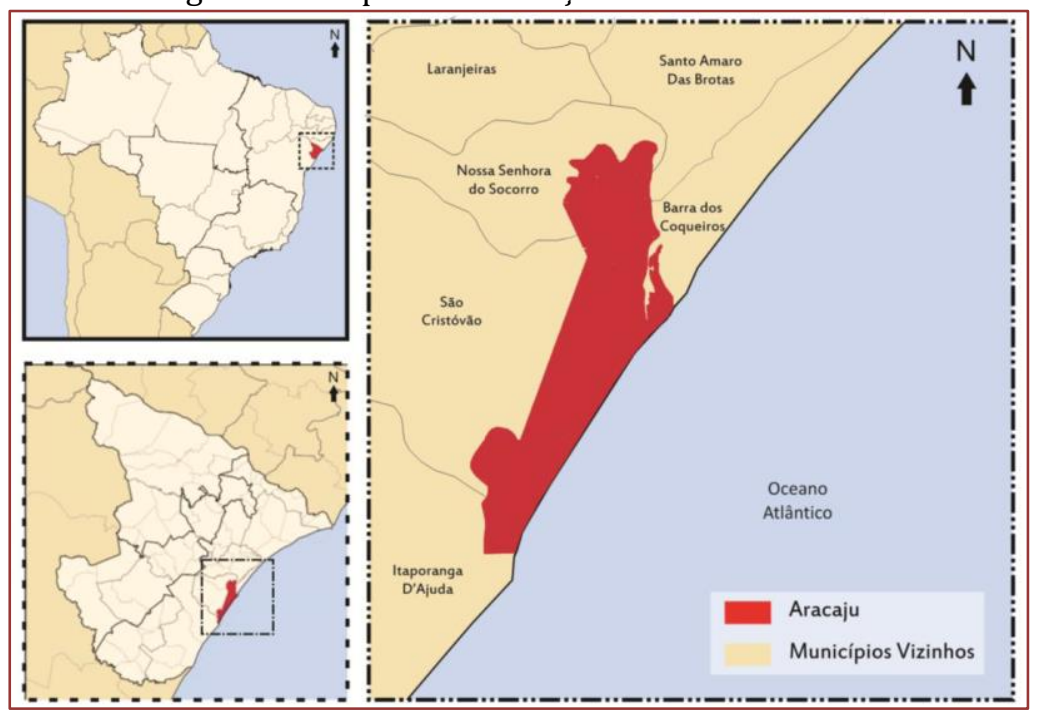

Fonte: França, 2011

\subsection{COLETA DE DADOS}

Para a realização da simulação, primeiro é necessário estabelecer um modelo de análise do sistema de gerenciamento, que compreenda as atividades que envolvem o processamento dos resíduos. 0 fluxo do processo pode ser pensado de acordo com o que está descrito na Resolução 307 do CONAMA, obedecendo a ordem de tratamento desses materiais, conforme a figura 02 .

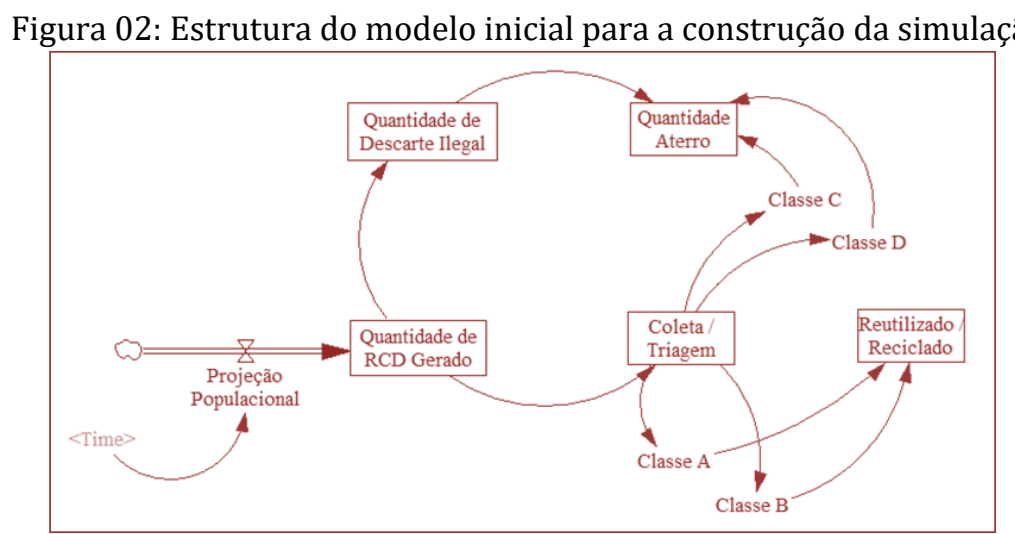

Fonte: Autor, 2018. Ferramenta: Vensim

O sistema apresenta a ordem de prioridade dada nas etapas do gerenciamento e inclui o descarte ilegal, que apesar de não fazer parte do gerenciamento correto, ainda está presente no modelo atual, por falta de fiscalização adequada.

Definido o fluxo do sistema, tem-se as variáveis que irão ser utilizadas para validar o modelo. Foram utilizados dados históricos que constam no censo populacional de 2010, publicado no Diagnóstico dos Resíduos Sólidos da Construção Civil, realizado pelo Instituto de Pesquisa Econômica Aplicada (IPEA, 2012), pelo Panorama dos Resíduos Sólidos no Brasil em 2016, publicado pela ABRELP (2016), pelo Diagnóstico dos Resíduos Sólidos da Construção Civil em Aracaju, realizado pelo SINDUSCON / SE (2005) e uma pesquisa de campo realizada junto a EMSURB. 
Geração de RCD: A estimativa de geração de RCD em uma cidade é um fator difícil de se mensurar. Dessa forma, será considerado um valor médio estimado para a geração de RCD nas cidades brasileiras estabelecido por um estudo de Karpinsk et al., (2009) de 0,5t anual por habitante.

Coleta e Triagem dos RCD: No último panorama divulgado e apresentado pelo SINDUSCON/SE (2005), sobre os RCD em Aracaju, foi identificado que 60\% dos resíduos da construção coletado possuem origem em depósitos irregulares, 35\% de construções novas e 5\% de reformas.

Quanto a sua composição, quando separado por classe, segundo a resolução 307 do CONAMA, 73,44\% são resíduos de Classe A, 2,46\% são de Classe B; 23,24\% são de Classe C e 0,86\% são de Classe D.

Reuso e Reciclagem do RCD: Os resíduos, depois de passar pelo processo de coleta e triagem, podem ser de interesse comercial, podendo ser utilizado sem processamento ou podem ser reciclados, aumentando o leque de utilização de acordo com as características atingidas no processamento. 0 processo pode apresentar custos. Por isso, deve-se verificar a possibilidade de uso no próprio local. O processo de escolha para reuso e reciclagem abrange a classificação dada pela Resolução 307 do CONAMA. Dessa forma, a classe determina o destino do material.

Disposição final dos RCD: A disposição final dos resíduos da construção ocorre nos aterros sanitários de forma adequada, quando não existe possibilidade de uso desses materiais. Atualmente vemos um grande número de materiais em estado aproveitável sendo dispostos nesses locais, porém o que não se leva em conta, além do desperdício inerente da prática, é a diminuição da capacidade do aterro.

De acordo com estimativas do SINDUSCON/SE, 38\% dos resíduos sólidos urbanos de Aracaju depositado no aterro são provenientes da construção civil e a pesquisa assegura que desse total descartado $80,84 \%$ possui potencial de reciclagem e/ou reutilização.

Cenários Considerados: Os cenários foram propostos afim de avaliar os prejuízos decorrentes da não aplicação do gerenciamento correto dos resíduos da construção. Foram analisados prejuízos econômicos e ambientais, já que cada material usado na indústria da construção possui um custo associado e existe toda uma cadeia de produção que envolvem gastos energéticos e emissões de poluentes na atmosfera. Com isso, foram determinados dois cenários para uma simulação com período de 20 anos.

Cenário 1: Avaliou o processo de acordo com o que é praticado atualmente, conforme as informações de geração, coleta e disposição apresentado em pesquisas;

Cenário 2: 0 processo é visto na perspectiva ideal de como deve ser realizado o gerenciamento.

As variáveis analisadas, assim como os dados utilizados se encontram no quadro 01.

Quadro 01: Detalhamento dos cenários executados no modelo

\begin{tabular}{|c|c|c|c|}
\hline \multirow{2}{*}{ TAXAS } & \multicolumn{2}{|c|}{ CENÁRIOS } & \multirow{2}{*}{ Observações } \\
\hline & ATUAL & IDEAL & \\
\hline $\begin{array}{l}\text { Crescimento } \\
\text { Populacional }\end{array}$ & $\begin{array}{l}\text { Método } \\
\text { Logístico }\end{array}$ & $\begin{array}{l}\text { Método } \\
\text { Logístico }\end{array}$ & $\begin{array}{l}\text { Foram utilizados os mesmos dados de crescimento populacional nos } \\
\text { dois cenários. Para isso, a estimativa população foi realizada pelo } \\
\text { método logístico. }\end{array}$ \\
\hline $\begin{array}{l}\text { Geração de } \\
\text { RCD per capita }\end{array}$ & $0.5 \mathrm{t} / \mathrm{hab} / \mathrm{ano}$ & $\begin{array}{l}0.5 \mathrm{t} / \mathrm{hab} / \mathrm{an} \\
\mathrm{o}\end{array}$ & $\begin{array}{l}\text { Foi utilizado dados do estudo de Karpinsk et al., (2009), para os dois } \\
\text { cenários }\end{array}$ \\
\hline $\begin{array}{l}\text { Quantidade de } \\
\text { descarte ilegal }\end{array}$ & $60 \%$ & $0 \%$ & $\begin{array}{l}\text { Foi utilizado proporção do último diagnóstico dos resíduos em } \\
\text { Aracaju (2005), sendo que o ideal é não existir descarte ilegal }\end{array}$ \\
\hline $\begin{array}{l}\text { Coleta e } \\
\text { triagem }\end{array}$ & $40 \%$ & $100 \%$ & $\begin{array}{l}\text { Foi utilizado proporção do último diagnóstico dos resíduos em } \\
\text { Aracaju (2005), sendo que o ideal é todo RCD gerado ser coletado }\end{array}$ \\
\hline Classe A & $73.44 \%$ & $73.44 \%$ & \multirow{4}{*}{$\begin{array}{l}\text { Proporção da composição média dos RCD de Aracaju, no último } \\
\text { panorama avaliado (2005). A proporção foi mantida para o cenário } \\
\text { ideal. }\end{array}$} \\
\hline Classe B & $2.46 \%$ & $2.46 \%$ & \\
\hline Classe C & $23.24 \%$ & $23.24 \%$ & \\
\hline Classe D & $0.86 \%$ & $0.86 \%$ & \\
\hline $\begin{array}{l}\text { Reutilização / } \\
\text { Reciclagem }\end{array}$ & $\begin{array}{l}\text { Classe A + } \\
\text { Classe B }\end{array}$ & $\begin{array}{l}\text { Classe A + } \\
\text { Classe B }\end{array}$ & $\begin{array}{l}\text { Segundo Resolução no307 do CONAMA, os resíduos classe A e B, } \\
\text { podem e devem ser utilizados e/ou reciclados }\end{array}$ \\
\hline Aterro & $\begin{array}{l}\text { Descarte ilegal } \\
+ \text { Classe C }+ \\
\quad \text { Classe D }\end{array}$ & $\begin{array}{l}\text { Descarte } \\
\text { ilegal + } \\
\text { Classe C + } \\
\text { Classe D }\end{array}$ & $\begin{array}{l}\text { Segundo Resolução no307 do CONAMA, os resíduos classe C e D, } \\
\text { podem e devem ser descartados de acordo com normas específicas }\end{array}$ \\
\hline
\end{tabular}


Validação do Modelo: De acordo com Simonetto et al. (2016), uma das partes mais importantes de uma modelagem computacional, com representação de sistemas reais é a verificação e validação do modelo, a fim de garantir que o mesmo esteja isento de erros de concepção. Portanto, a verificação e validação foi realizada durante a concepção do modelo.

Em um primeiro momento, foi utilizado um modelo conceitual a partir da cadeia de gerenciamento dos RCD abordado na Resolução no 304 do CONAMA (2012), o qual aborda as etapas que os Resíduos devem passar até a sua destinação final. Porém, foram levados em consideração os fatores que estavam relacionados diretamente ao problema, como coleta, triagem e destinação final. Nesse esquema foi abordado o descarte irregular, chamados de "bota-fora", que consiste em um dos problemas mais críticos do assunto e a reutilização e reciclagem dos materiais coletados.

Na segunda etapa, os dados foram implementados no Vensim PLE (VENTANA SYSTEMS, versão 7.2, onde foram utilizados dados históricos do cenário atual e foram analisadas as saídas produzas pelo modelo. Os dados foram projetados para um intervalo de tempo de 20 anos.

A terceira etapa consiste na análise de um cenário ideal para o gerenciamento do modelo, onde não existe descarte ilegal dos mesmos. Com isso, todo o valor gerado de RCD foi destinado para a coleta e por sua vez para o reuso e reciclagem.

\subsection{ANÁLISE DOS DADOS}

Os dados serão analisados com o auxílio do programa Vensim e excel, tendo como produto gráficos com quantitativos que possuem a finalidade de representar o cenário que está sendo trabalhado.

Com isso, temos duas análises a serem realizadas, do ponto de vista quantitativo e qualitativo. A interface com o programa, apresentará resultados a partir de gráficos, trazendo o problema em forma de números. A partir de então, os dados serão, por sua vez, analisados sob a ótica qualitativa, apresentando debates a respeito do problema.

\section{RESULTADO E DISCUSSÃO}

\subsection{RELAÇÃO ENTRE CRESCIMENTO POPULACIONAL E GERAÇÃO DE RCD}

Conforme Karpinsk et al. (2009), a geração de RCD está estimado em uma média de 0,5hab/ano, para as cidades brasileiras. A relação está diretamente relacionada com o quantitativo populacional. Como estamos trabalhando com um cenário de 20 anos precisamos prever qual será o quantitativo populacional nesse período de tempo.

Tsutiya (2006), descreve três tipos de métodos matemáticos para prever população futura, baseada em dados históricos, são eles: método aritmético; método geométrico; método da curva logística.

Em sua pesquisa, Penner, Dias e Junior (2017), recomendam o método logístico para a realização da projeção populacional com base na precisão obtida, quando comparado com os outros métodos. Com isso, iremos considerar para a pesquisa a previsão populacional baseada no método logístico.

A equação do método logístico é a seguinte:

$$
P=\frac{P_{S}}{1+c * e^{K_{1}\left(t-t_{0}\right)}}
$$

Onde:

e: é a base dos logaritmos neperianos;

$\mathrm{t}, \mathrm{t}_{0}$ : ano da projeção e ano inicial $\left(\mathrm{t}_{0}\right)$;

$\mathrm{P}_{\mathrm{S}}$ : população de saturação;

K1, c: coeficiente de projeção.

As equações dos parâmetros da curva logística são definidas a partir das seguintes expressões:

$$
P_{S}=\frac{2 P_{0} P_{1} P_{2}-\left(P_{1}\right)^{2}\left(P_{0}+P_{2}\right)}{P_{0} P_{2}-\left(P_{1}\right)^{2}} ; \quad c=\left(P_{S}-P_{0}\right) / P_{0} ; \quad K_{1}=\frac{1}{t_{2}-t_{1}} \ln \left(\frac{P_{0}\left(P_{S}-P_{1}\right)}{P_{1}\left(P_{S}-P_{S}\right)}\right)
$$

Onde:

$\mathrm{P}_{0}$; $\mathrm{P}_{1}$ e $\mathrm{P}_{2}$ : populações no ano $t_{0}, \mathrm{t}_{1}, \mathrm{t}_{2}$; 
Para a realização da estimativa populacional, foram tomados dados censitários nos anos de 2007, 2012 e 2017 e foram calculados os parâmetros para a estimativa populacional, como mostrado na tabela 01a e $01 \mathrm{~b}$.

Tabela 01: a) População de Aracaju nos anos de 2007; 2012 e 2017; b) Coeficiente da curva logística calculado.

a)

\begin{tabular}{c|c}
\hline Ano Base & População \\
\hline 2007 & 520.303 \\
\hline 2012 & 587.701 \\
\hline 2017 & 650.106 \\
\hline
\end{tabular}

b)

\begin{tabular}{c|c}
\hline \multicolumn{2}{c}{$\begin{array}{c}\text { Coeficientes da curva } \\
\text { logística }\end{array}$} \\
\hline $\mathrm{PS}_{\mathrm{S}}$ & 933881 \\
\hline $\mathrm{C}$ & 0.7949 \\
\hline $\mathrm{K}_{1}$ & -0.0599 \\
\hline
\end{tabular}

Fonte: a) IBGE; b) Autor, 2018

A partir desses dados e aplicando a equação do método logístico, temos a projeção da população apresentada na tabela 02.

Tabela 02: Projeção para o período de 2017 a 2037

\begin{tabular}{|c|c|c|c|c|c|c|c|}
\hline \multicolumn{8}{|c|}{ População (hab.) } \\
\hline Ano & Pop. Censo & Logística & Saturação & Ano & $\begin{array}{l}\text { Pop. } \\
\text { Censo }\end{array}$ & Logística & Saturação \\
\hline 2007 & 520303 & & & 2027 & & 753309 & 933881 \\
\hline 2012 & 587701 & & & 2028 & & 761879 & 933881 \\
\hline 2017 & 650106 & & & 2029 & & 770131 & 933881 \\
\hline 2018 & & 661806 & 933881 & 2030 & & 778068 & 933881 \\
\hline 2019 & & 673216 & 933881 & 2031 & & 785695 & 933881 \\
\hline 2020 & & 684329 & 933881 & 2032 & & 793016 & 933881 \\
\hline 2021 & & 695136 & 933881 & 2033 & & 800036 & 933881 \\
\hline 2022 & & 705631 & 933881 & 2034 & & 806763 & 933881 \\
\hline 2023 & & 715809 & 933881 & 2035 & & 813203 & 933881 \\
\hline 2024 & & 725667 & 933881 & 2036 & & 819363 & 933881 \\
\hline 2025 & & 735204 & 933881 & 2037 & & 825250 & 933881 \\
\hline 2026 & & 744417 & 933881 & 2038 & & 830873 & 933881 \\
\hline
\end{tabular}

Fonte: Autor, 2018

Com os dados populacionais definidos, podemos atribuir, no Vensim, os valores de entrada para modelagem da geração de RCD. Assim, temos como resultado, os gráficos na figura 05a e 05b. 
Figura 5: a) Gráfico da projeção populacional de Aracaju, baseado no método logístico; b) geração de RCD de Aracaju entre 2018 e 2038, estimando 0,5t/hab/ano

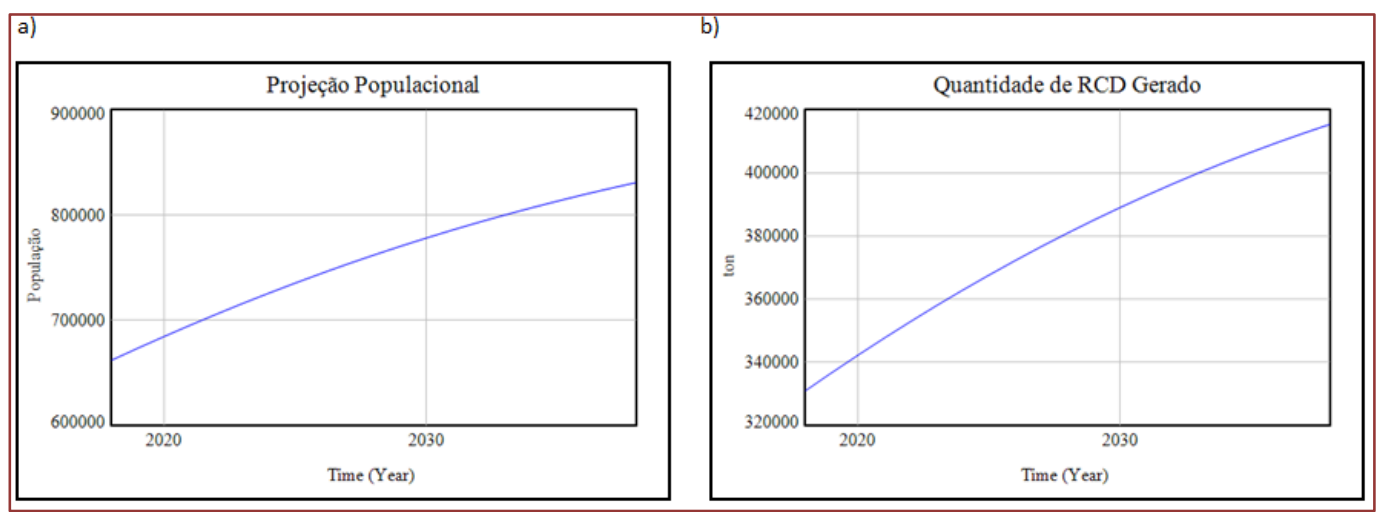

Fonte: Autor, 2018. Ferramenta: Vensim

Os valores de crescimento populacional e de geração de RCD serão os mesmos na modelagem dos dois cenários propostos, visto que esses valores não sofrem influência com a mudança de cenário.

Na figura 5b, apresentada, no período de 20 anos ocorreu uma geração total de 7.939 .400 toneladas de RCD. Essa quantidade gerada pode ser reduzida aplicando metodologias de trabalho e com a mudança de paradigmas no que diz respeitos às atividades da construção civil. Um bom gerenciamento da obra, como um todo, reflete na propagação de boas ideias e na melhora dos resultados apresentados.

Rêgo (2015) cita que a utilização da ferramenta de qualidade PDCA (Plan - Do - Check - Action) empregada como instrumento de gerenciamento do processo proporciona a diminuição da geração de resíduos e até mesmo tem o objetivo de impedir efeitos adversos no meio ambiente. 0 ciclo PDCA é um método que visa resultados de forma eficaz e confiável nas atividades de uma organização, padronizando as informações do controle de qualidade, de modo a evitar erros nas análises, tonando as informações mais fáceis de entender.

Segundo Bueno (2015), existem formas de reduzir a geração dos resíduos na obra de forma eficaz e positiva com a adoção de medidas através de planos de gerenciamento eficaz como a introdução de uma cultura de redução a partir de hábitos que devem estar claros para toda a equipe envolvida. A autora sugere dois métodos de sistematização da cultura de redução como os 3Rs e os 5Ss.

Araújo (2015), propõe a otimização do canteiro de obras com a utilização do método Systematc Layout Planning (SLP), que consiste em aumentar a eficiência dos processos reduzindo distâncias de deslocamentos, garantindo a diminuição da perda de materiais durante o processo de execução e consequentemente diminuindo a. geração dos resíduos durante os trabalhos

O Ministério das Cidades (2017), a partir do Sistema de Avaliação da Conformidade de Empresas de Serviços e Obras da Construção Civil (SiAC), incorporou o Programa Brasileiro da Qualidade e Produtividade do Habitat (PBQP-H) que tem como objetivo contribuir com a qualidade, produtividade e sustentabilidade na construção civil. Em relação aos RCD, o PBQP-H, propõe indicadores de geração dos resíduos ao longo e ao final da obra, assim como construção de um plano de qualidade da obra que visa a destinação adequada desses materiais.

\subsection{CENÁRIO ATUAL}

Definido os dados de geração de RCD, foram considerados dados históricos para prever o comportamento dos processos de descarte ilegal, disposição em aterro sanitário e coleta / triagem dos materiais. Os dados utilizados foram retirados do relatório de diagnóstico resíduos sólidos da construção civil em Aracaju, realizado em 2005 em conjunto com o SINDUSCON/SE, EMSURB, SEMA, UFS e o projeto competir do SEBRAE/ SENAI/ GTZ, lembrando que apesar de ser um relatório antigo, é o único e último divulgado em caráter oficial. Vale ressaltar que serão utilizados dados relativos a porcentagem representativa da composição dos RCD e a origem desses materiais, visto que essas relações de proporcionalidade possuem pouca variação com o passar do tempo, e conforme o próprio relatório, estão alinhados com o que é praticado no resto do país. 
Segundo quadro 02, será considerado para a simulação que 60\% dos resíduos quantificado possui como origem os depósitos irregulares e que a composição dos materiais por classe será representada como: Classe A - 73,44\%; Classe B - 2,46\%; Classe C - 23,24\%; Classe D - 0,86\%. Assim sendo, foram gerados os resultados apresentados nos gráficos das figuras $07 \mathrm{a}, 07 \mathrm{~b}, 07 \mathrm{c}$ e $07 \mathrm{~d}$.

Figura 07: Gráficos do resultado da simulação cenário atual - a) Descarte Ilegal; b) Coleta / Triagem; c) Aterro; d) Quantidade de RCD Reutilizado/ Reciclado.

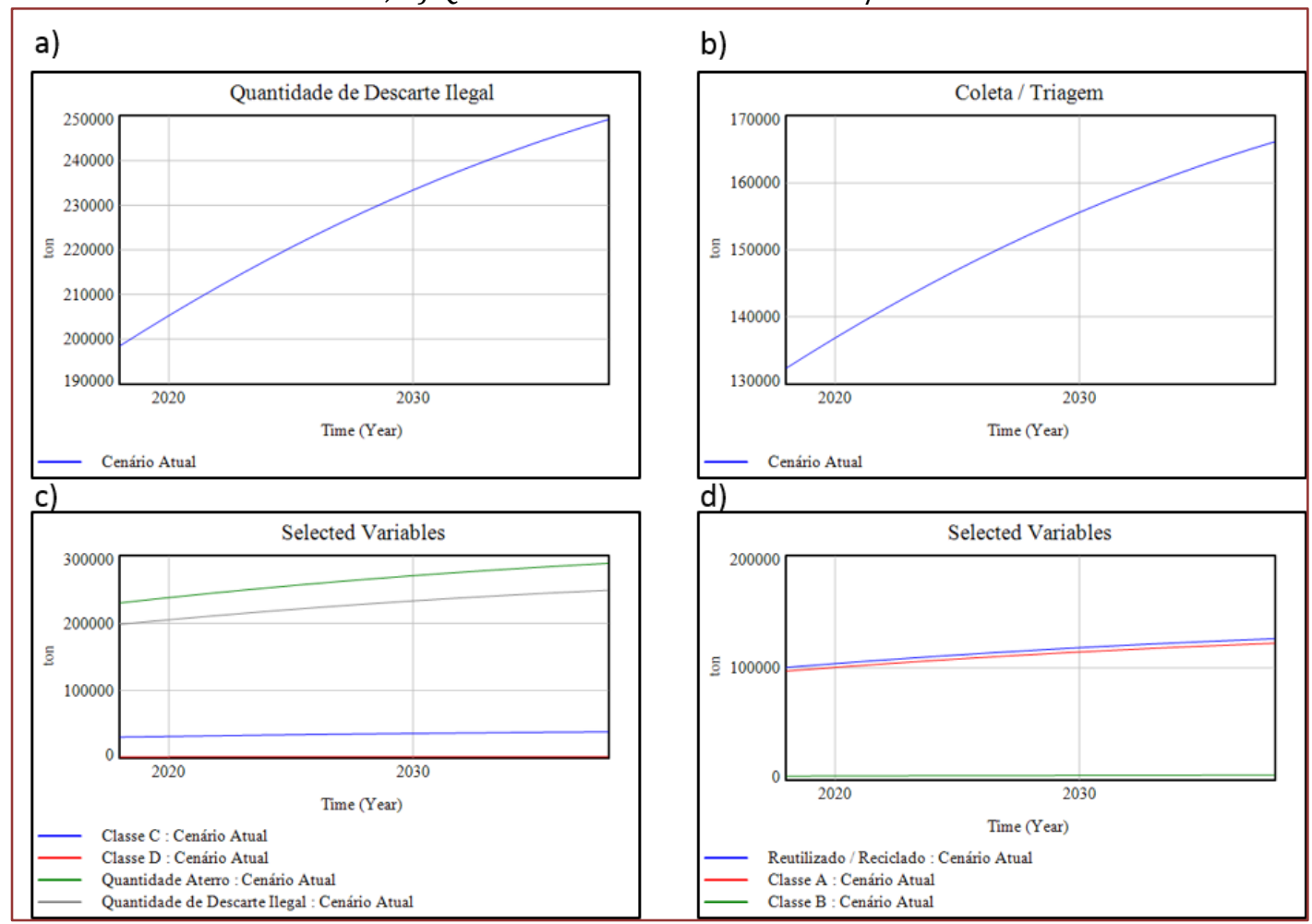

Fonte: Autor, 2018. Ferramenta: Vensim

Um dos grandes problemas oriundos do cenário atual é a disposição irregular dos RCD, de acordo com a figura 07a. Segundo Souza (2017), os principais impactos ambientais e causados a sociedade urbana estão diretamente relacionados com a disposição irregular desses resíduos, ocasionando um desequilíbrio e comprometendo a paisagem, degradando os mananciais e obstruindo os sistemas de drenagem, além de proliferar vetores causadores de doenças.

De acordo com a EMSURB (pesquisa de campo), Aracaju possui cerca de 268 pontos de depósitos irregulares, sendo que falta a finalização desse levantamento, com isso percebemos que esse valor pode ser ainda maior. Conforme Estácio (2015), a própria população contrata os carroceiros para descartar esses resíduos que por sua vez o colocam em locais inadequados. Pela lei municipal 4.452 do Sistema de Gestão Sustentável dos Resíduos de Construção Civil e Volumosos existe uma multa que deve ser aplicada nesses casos no valor de até $\mathrm{R} \$ 500$ mil reais, quando o descarte é realizado em locais de preservação.

Outro fator que está relacionado diretamente com os depósitos irregulares são os custos com a coleta desse material pela prefeitura. Valores esses que poderiam ser destinados para fins de saúde e educação estão sendo empregados com a finalidade de recolher esses materiais. Como informado pela EMSURB (pesquisa de campo), a estimativa de custo per capta para a coleta mensal dos resíduos da construção é de $\mathrm{R} \$ 0,40$ e de $\mathrm{R} \$ 0,20$ para a destinação destes resíduos. Com esse valor podemos estimar um custo anual de $\mathrm{R} \$ 7,20$ per capta. Considerando esse valor anual, sem levar em conta a atualização monetária, vemos que no período considerado temos um gasto total acumulado estimado em $\mathrm{R} \$ 114.327 .354,77$. Na figura 08 temos os valores referentes aos gastos anuais. 
Figura 08: Gráfico de custo anual de remoção dos depósitos irregulares em Aracaju

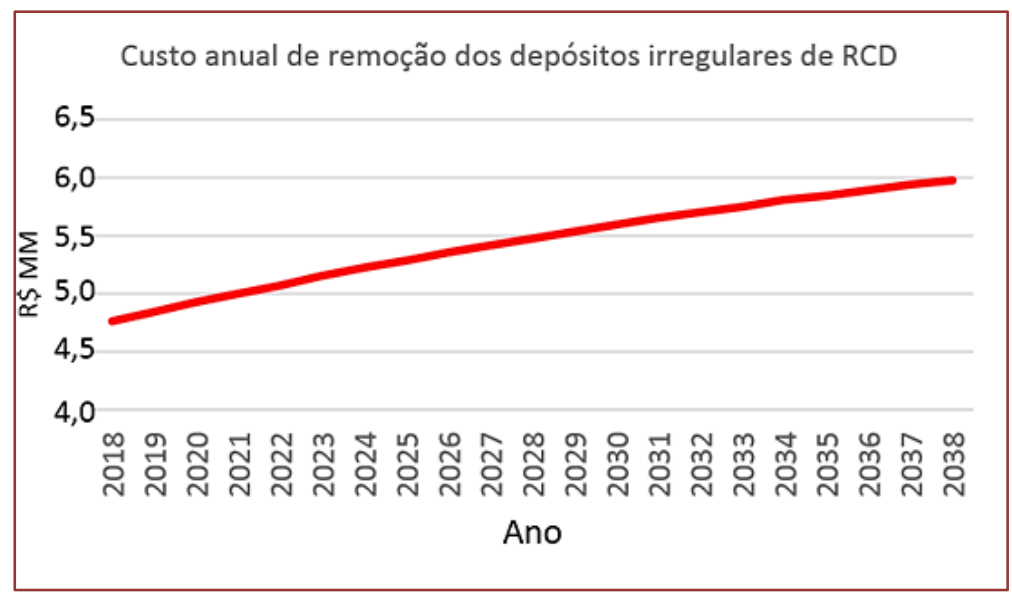

Fonte: Autor, 2018

No último relatório divulgado pelo SINDUSCON / SE (2005), a estimativa de custo per capta, para a coleta dos RCD, dos depósitos irregulares em Aracaju era em torno de R\$6,05/ano*hab.

Segundo a EMSURB (pesquisa de campo), entre os meses de setembro de 2017 a março de 2018, foram coletados em Aracaju aproximadamente 28.400 toneladas mensalmente de RSU, desse valor 4.200 toneladas são RCD. A partir desse dado podemos estimar que nesse período $15 \%$ dos resíduos coletados são RCD, um valor baixo quando comparado com dados anteriores, como registrado no último diagnóstico em 2005 que representava uma porcentagem de aproximadamente 65\%. Podemos atribuir esse baixo índice ao panorama atual em que se encontra a atividade da construção civil que teve uma queda significativa e influenciou o índice de geração de RCD na cidade.

Associado ao descarte ilegal dos RCD, temos um aumento da quantidade dos materiais que chegam ao aterro sanitário. Nesse cenário temos um valor acumulado para o período de 5.528.998 toneladas de RCD que chegam aos aterros, conforme figura 07c. Segundo Primo et al. (2016), o aterro da Estre, localização em Rosário do Catete e que recebe resíduos de Aracaju, possui uma vida útil de 32 anos utilizando a capacidade de tratamento máximo diário de 2,3 mil toneladas de lixo por dia. 0 descarte ilegal contribui para a diminuição da vida útil do aterro sanitário.

De acordo com a Resolução CONAMA no 307 (2002), fica vetado a destinação dos RCD para aterros de resíduos domiciliares e depósitos irregulares e toda fração reutilizável ou reciclável deverá retornar ao processo produtivo, caso contrário, devem ser dispostas em aterros exclusivo para esses fins.

A tabela 04 mostra os resultados da modelagem compatibilizados, para uma melhor compreensão do que foi apresentado e discutido. 
Tabela 04: Resultados da modelagem de cenário - Atual

\begin{tabular}{|c|c|c|c|c|c|c|c|c|c|c|}
\hline \multirow{3}{*}{ Ano } & \multicolumn{9}{|c|}{ Dados sobre o comportamento dos resíduos em 20 anos - cenário atual } & \multirow{3}{*}{$\begin{array}{c}\text { Reutilizad } \\
\text { / Reciclad } \\
\text { ton. }\end{array}$} \\
\hline & População & RCD Gerado & Descarte Ilegal & $\begin{array}{l}\text { Custo com } \\
\text { Remoção de } \\
\text { irregulares }\end{array}$ & \multicolumn{4}{|c|}{$\begin{array}{l}\text { Materiais Coletado / Triado } \\
\text { (40\% dos RCD Gerado) ton. }\end{array}$} & Aterro & \\
\hline & hab. & ton. & ton. & $\mathrm{R} \$$ & Classe A & Classe B & Classe C & Classe D & ton. & \\
\hline 2018 & 661805.60 & 330902.80 & 198541.68 & 4765000.33 & 97206.01 & 3256.08 & 30760.72 & 1138.31 & 230440.71 & 100462.09 \\
\hline 2019 & 673216.25 & 336608.13 & 201964.88 & 4847157.01 & 98882.00 & 3312.22 & 31291.09 & 1157.93 & 234413.90 & 102194.23 \\
\hline 2020 & 684328.80 & 342164.40 & 205298.64 & 4927167.35 & 100514.21 & 3366.90 & 31807.60 & 1177.05 & 238283.29 & 103881.11 \\
\hline 2021 & 695135.61 & 347567.80 & 208540.68 & 5004976.39 & 102101.52 & 3420.07 & 32309.90 & 1195.63 & 242046.22 & 105521.59 \\
\hline 2022 & 705630.52 & 352815.26 & 211689.16 & 5080539.78 & 103643.01 & 3471.70 & 32797.71 & 1213.68 & 245700.55 & 107114.71 \\
\hline 2023 & 715808.83 & 357904.41 & 214742.65 & 5153823.56 & 105138.00 & 3521.78 & 33270.79 & 1231.19 & 249244.63 & 108659.78 \\
\hline 2024 & 725667.18 & 362833.59 & 217700.15 & 5224803.71 & 106586.00 & 3570.28 & 33729.01 & 1248.15 & 252677.31 & 110156.28 \\
\hline 2025 & 735203.57 & 367601.78 & 220561.07 & 5293465.70 & 107986.70 & 3617.20 & 34172.26 & 1264.55 & 255997.88 & 111603.90 \\
\hline 2026 & 744417.22 & 372208.61 & 223325.17 & 5359803.98 & 109340.00 & 3662.53 & 34600.51 & 1280.40 & 259206.08 & 113002.53 \\
\hline 2027 & 753308.53 & 376654.27 & 225992.56 & 5423821.43 & 110645.96 & 3706.28 & 35013.78 & 1295.69 & 262302.03 & 114352.24 \\
\hline 2028 & 761879.00 & 380939.50 & 228563.70 & 5485528.78 & 111904.79 & 3748.44 & 35412.14 & 1310.43 & 265286.27 & 115653.23 \\
\hline 2029 & 770131.11 & 385065.55 & 231039.33 & 5544943.99 & 113116.86 & 3789.05 & 35795.69 & 1324.63 & 268159.65 & 116905.90 \\
\hline 2030 & 778068.28 & 389034.14 & 233420.48 & 5602091.61 & 114282.67 & 3828.10 & 36164.61 & 1338.28 & 270923.37 & 118110.76 \\
\hline 2031 & 785694.75 & 392847.38 & 235708.43 & 5657002.22 & 115402.85 & 3865.62 & 36519.09 & 1351.39 & 273578.91 & 119268.46 \\
\hline 2032 & 793015.52 & 396507.76 & 237904.66 & 5709711.76 & 116478.12 & 3901.64 & 36859.36 & 1363.99 & 276128.00 & 120379.76 \\
\hline 2033 & 800036.24 & 400018.12 & 240010.87 & 5760260.91 & 117509.32 & 3936.18 & 37185.68 & 1376.06 & 278572.62 & 121445.50 \\
\hline 2034 & 806763.13 & 403381.57 & 242028.94 & 5808694.55 & 118497.37 & 3969.27 & 37498.35 & 1387.63 & 280914.92 & 122466.64 \\
\hline 2035 & 813202.94 & 406601.47 & 243960.88 & 5855061.16 & 119443.25 & 4000.96 & 37797.67 & 1398.71 & 283157.26 & 123444.21 \\
\hline 2036 & 819362.82 & 409681.41 & 245808.84 & 5899412.27 & 120348.01 & 4031.27 & 38083.98 & 1409.30 & 285302.13 & 124379.28 \\
\hline 2037 & 825250.27 & 412625.14 & 247575.08 & 5941801.94 & 121212.76 & 4060.23 & 38357.63 & 1419.43 & 287352.14 & 125272.99 \\
\hline 2038 & 830873.10 & 415436.55 & 249261.93 & 5982286.32 & 122038.64 & 4087.90 & 38618.98 & 1429.10 & 289310.01 & 126126.54 \\
\hline Total & 15878799.27 & 7939399.64 & 4763639.78 & 114327354.77 & 2332278.04 & 78123.69 & 738046.59 & 27311.53 & 5528997.91 & 2410401.73 \\
\hline
\end{tabular}

Fonte: Autor, 2018

\subsection{CENÁRIO IDEAL}

O cenário ideal, como o próprio nome remete, tem a finalidade de desenvolver um esquema de acordo com o que está abordado na Resolução do CONAMA no 307, sendo a principal característica não gerar descarte ilegal (figura 09a) dos RCD e os materiais que configuram Classe C e D serem destinados em aterros próprios. A partir disso, segue os resultados dessa configuração adotada. Para melhor entendimento dos resultados, usou-se os dados do cenário atual como comparativo.

A simulação não considerou uma fase de transição para o cenário ideal. 0 que está sendo proposto é uma análise entre dois cenários, separadamente.

Na figura 09b temos a representação do comportamento da coleta e triagem a qual representa $100 \%$ dos RCD gerado. Quando comparado com o cenário atual, temos um aumento efetivo de 250\% na quantidade de materiais coletados e triados.

Em referência ao cenário ideal e para mostrar que zerar a disposição ilegal é algo viável, conforme noticiado pela FIESP (2012), a Holanda é uma referência mundial na gestão de resíduos, conseguindo reciclar cerca de $80 \%$ dos seus resíduos e apenas 3 a $4 \%$ seguem para aterros, não existindo descarte ilegal desses materiais.

Sem o descarte ilegal, temos um aumento dos materiais que serão reutilizados e reciclados, depois de passarem pela triagem (figura 09c) aumentando a possibilidade desse material retornar a cadeia produtiva.

Os RCD coletados e classificados como classe A são encaminhados para a usina recicladora de RCD situada no município de Nossa Senhora do Socorro, porém ela possui uma capacidade operativa de 25 mil toneladas por mês. Vemos, nesse caso, que a usina passaria a operar com toda a sua capacidade, com isso temos a possibilidade de aumentar a capacidade operativa ou construir outra usina de reciclagem de RCD. 
A proposta de aumentar a quantidade de materiais reutilizado e reciclados é favorável quando temos um encarecimento desses mesmos materiais na indústria. Segundo o Núcleo de Informações Econômicas de Sergipe (2018) 54,4\% dos custos da construção civil corresponde aos gastos com materiais.

Figura 09: Gráfico do resultado simulação cenário ideal - a) Descarte Ilegal; b) Coleta / Triagem; c) Reutilizado / Reciclado d) Aterro.

a)

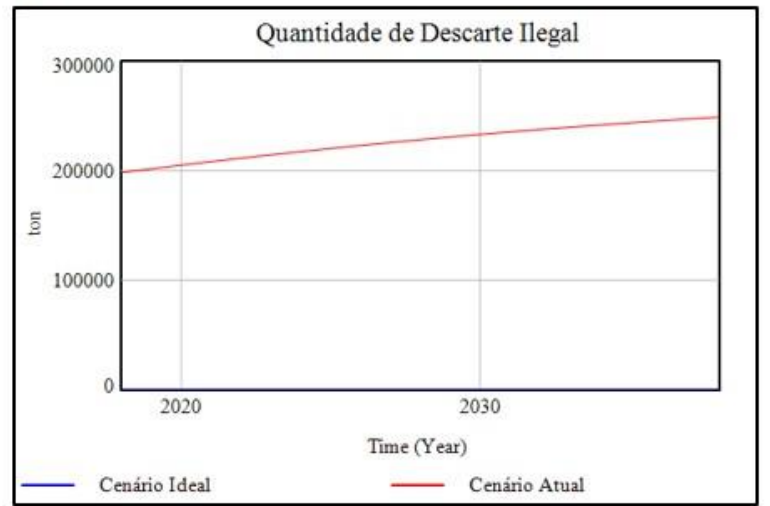

c)

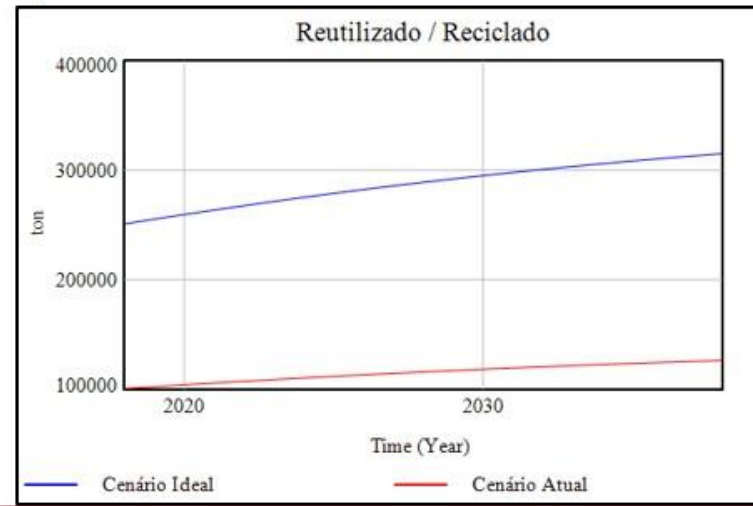

b)

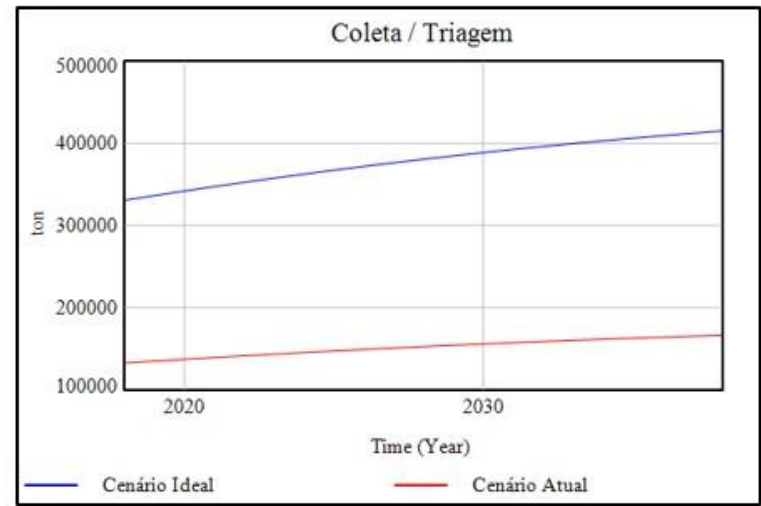

d)

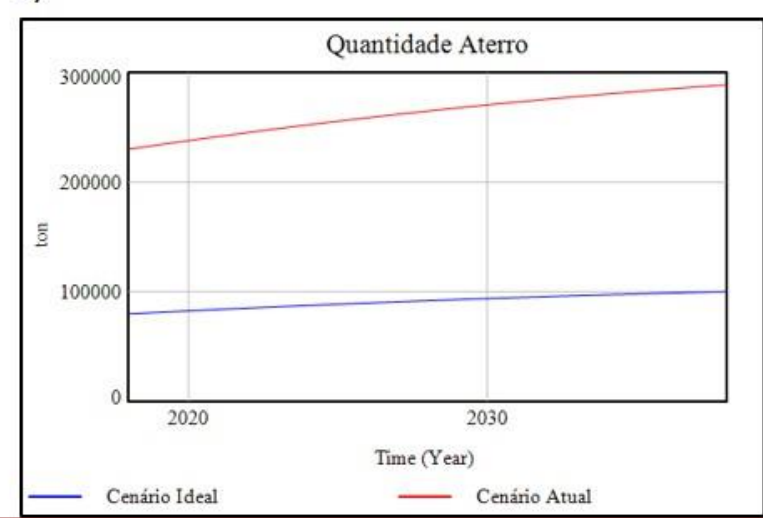

Fonte: Autor, 2018. Ferramenta: Vensim

Em um cenário em que os materiais constituem mais da metade do custo de uma obra e existe aumento desses custos por correções, a reutilização e reciclagem é uma saída para diminuição dos custos, aumentando os lucros e priorizando as questões ambientais. A exemplo disso, em Sorocaba, construtoras que possuem sistema de reciclagem economizam cerca de 15 a $25 \%$ dos custos da obra (BRASILENGENHARIA, 2012).

Como apresentado na figura 09d, somente os materiais de classe C e D são destinados aos aterros. Lima e Lima (2012), informam que para os resíduos de categoria C e D, deve-se ocorrer o envolvimento dos fornecedores de materiais para exigir corresponsabilidade na destinação dos mesmos. Ou seja, os fabricantes devem realizar uma política de logística reversa para garantir que esse tipo de material, que não podem ser descartados de qualquer maneira, sejam destinados corretamente de acordo com as leis vigentes e atender ao que está disposto na Política Nacional dos Resíduos Sólidos (PNRS).

Os resultados da simulação do cenário ideal estão compatibilizados na tabela 05. 
Tabela 05: Resultados da modelagem de cenário - Ideal

\begin{tabular}{|c|c|c|c|c|c|c|c|c|c|}
\hline \multirow{3}{*}{ Ano } & \multicolumn{8}{|c|}{ Dados sobre o comportamento dos residuos em 20 anos - cenário ideal } & \multirow{3}{*}{\begin{tabular}{|c|} 
Reutilizado/Reciclado \\
ton
\end{tabular}} \\
\hline & \multirow{2}{*}{$\begin{array}{c}\text { População } \\
\text { hab }\end{array}$} & \multirow{2}{*}{$\begin{array}{c}\text { RCD } \\
\text { Gerado } \\
\text { ton }\end{array}$} & \multirow{2}{*}{\begin{tabular}{|c|}
$\begin{array}{c}\text { Coletado/ } \\
\text { Triado }\end{array}$ \\
ton
\end{tabular}} & \multicolumn{4}{|c|}{$\begin{array}{l}\text { Materiais Coletado / Triado ( } 100 \% \text { dos RCD Gerado) } \\
\text { ton. }\end{array}$} & \multirow{2}{*}{$\begin{array}{c}\text { Aterro } \\
\text { ton }\end{array}$} & \\
\hline & & & & Classe A & Classe B & Classe C & Classe D & & \\
\hline 2018 & 661805,60 & 330902,80 & 330902,80 & 243015,02 & 8140,21 & 76901,81 & 2845,76 & 79747,57 & 251155,23 \\
\hline 2019 & 673216,25 & 336608,13 & 336608,13 & 247205,01 & 8280,56 & 78227,73 & 2894,83 & 81122,56 & 255485,57 \\
\hline 2020 & 684328,80 & 342164,40 & 342164,40 & 251285,54 & 8417,24 & 79519,01 & 2942,61 & 82461,62 & 259702,78 \\
\hline 2021 & 695135,61 & 347567,80 & 347567,80 & 255253,80 & 8550,17 & 80774,76 & 2989,08 & 83763,84 & 263803,96 \\
\hline 2022 & 705630,52 & 352815,26 & 352815,26 & 259107,53 & 8679,26 & 81994,27 & 3034,21 & 85028,48 & 267786,78 \\
\hline 2023 & 715808,83 & 357904,41 & 357904,41 & 262845,00 & 8804,45 & 83176,99 & 3077,98 & 86254,96 & 271649,45 \\
\hline 2024 & 725667,18 & 362833,59 & 362833,59 & 266464,99 & 8925,71 & 84322,53 & 3120,37 & 87442,90 & 275390,70 \\
\hline 2025 & 735203,57 & 367601,78 & 367601,78 & 269966,75 & 9043,00 & 85430,65 & 3161,38 & 88592,03 & 279009,75 \\
\hline 2026 & 744417,22 & 372208,61 & 372208,61 & 273350,00 & 9156,33 & 86501,28 & 3200,99 & 89702,27 & 282506,33 \\
\hline 2027 & 753308,53 & 376654,27 & 376654,27 & 276614,89 & 9265,69 & 87534,45 & 3239,23 & 90773,68 & 285880,59 \\
\hline 2028 & 761879,00 & 380939,50 & 380939,50 & 279761,97 & 9371,11 & 88530,34 & 3276,08 & 91806,42 & 289133,08 \\
\hline 2029 & 770131,11 & 385065,55 & 385065,55 & 282792,14 & 9472,61 & 89489,23 & 3311,56 & 92800,80 & 292264,76 \\
\hline 2030 & 778068,28 & 389034,14 & 389034,14 & 285706,67 & 9570,24 & 90411,53 & 3345,69 & 93757,23 & 295276,91 \\
\hline 2031 & 785694,75 & 392847,38 & 392847,38 & 288507,11 & 9664,05 & 91297,73 & 3378,49 & 94676,22 & 298171,16 \\
\hline 2032 & 793015,52 & 396507,76 & 396507,76 & 291195,30 & 9754,09 & 92148,40 & 3409,97 & 95558,37 & 300949,39 \\
\hline 2033 & 800036,24 & 400018,12 & 400018,12 & 293773,31 & 9840,45 & 92964,21 & 3440,16 & 96404,37 & 303613,75 \\
\hline 2034 & 806763,13 & 403381,57 & 403381,57 & 296243,42 & 9923,19 & 93745,88 & 3469,08 & 97214,96 & 306166,61 \\
\hline 2035 & 813202,94 & 406601,47 & 406601,47 & 298608,12 & 10002,40 & 94494,18 & 3496,77 & 97990,95 & 308610,52 \\
\hline 2036 & 819362,82 & 409681,41 & 409681,41 & 300870,03 & 10078,16 & 95209,96 & 3523,26 & 98733,22 & 310948,19 \\
\hline 2037 & 825250,27 & 412625,14 & 412625,14 & 303031,90 & 10150,58 & 95894,08 & 3548,58 & 99442,66 & 313182,48 \\
\hline 2038 & 830873,10 & 415436,55 & 415436,55 & 305096,60 & 10219,74 & 96547,45 & 3572,75 & 100120,21 & 315316,34 \\
\hline Total & 15878799,27 & 7939399,64 & 7939399,64 & 5830695,09 & 195309,23 & 1845116,48 & 68278,84 & 1913395,31 & 6026004,32 \\
\hline
\end{tabular}

Fonte: Autor, 2018

\section{CONSIDERAÇÕES FINAIS}

Em relação aos RCD gerados, é crucial realizar um planejamento para um correto gerenciamento desses materiais. Ao utilizar o modelo de dinâmica de sistemas podemos perceber a gravidade do problema discutido ao longo do tempo e até mesmo auxiliar na tomada de decisões futuras. Entretanto, vemos que o maior problema está relacionado com os geradores desses materiais que se negam a realizar o procedimento adequado de destinação dos RCD pensando que com isso estão economizando. Porém a prefeitura tem um papel importante como gestor dos processos.

A redução dos resíduos deve ser enxergada desde a formulação dos projetos, com propostas que contribuam com o gerenciamento desses materiais. A mão de obra deve estar envolvida e preparada para lidar com esse tipo de problema, pensando neles fora do local de trabalho e percebendo na influência social e ambiental que a má gestão causa para eles e suas famílias.

Vale ressaltar que durante a pesquisa percebeu-se uma falta de divulgação de resultados quanto aos processos de coleta realizada pela prefeitura de Aracaju sendo que o relatório encontrado sobre o tema foi do ano de 2005. Com isso, propomos uma análise de divulgação de resultados anual pelos gestores para uma melhor conscientização sobre o problema assim como estimular estudos e possibilitar pesquisas na área.

Com isso, propomos trabalhos futuros com base no que foi apresentado para verificar a ocorrência de mudanças e assim realizar um ajuste na curva a partir do histórico gerado. E ainda, sugerimos um estudo 
mais detalhado levando-se em consideração a utilização de outras variáveis no estudo com a finalidade de aprofundar a análise dos problemas.

\section{REFERÊNCIAS}

[1] INDICADORES Contas Nacionais Trimestrais: Indicadores de volumes e valores correntes 2017. Rio de Janeiro: IBGE 2017.

[2] LAURIANO, Lucas Amaral. Relatório de Pesquisa: Como anda a gestão da sustentabilidade no setor da construção? Nova LIma: FDC, 2013. 2 p.

[3] Ministério do Meio Ambiente. Responsabilidade Socioambiental: Agenda 21. Disponível em:< http://www.mma.gov.br/responsabilidade-socioambiental/agenda-21> Acesso em: 01 maio 2018.

[4] RESOLUÇÃO CONAMA N³07. "Estabelece diretrizes, critérios e procedimentos para a gestão dos resíduos da construção civil". DOU no 136, 17 jul. 2002.

[5] FERNANDEZ, Jaqueline Aparecida Bória. Diagnóstico dos resíduos sólidos da construção civil. IPEA, Brasília, 2012.

[6] DALTRo FILHO, J. et al. Resíduos sólidos da Construção Civil em Aracaju: diagnóstico. Aracaju: SINDUSCON-SE. Projeto COMPETIR-SEBRAE/SENAI/GTZ, EMSURB, SEMA, 2005.

[7] KARPINSK, Luisete Andreis. Gestão diferenciada de resíduos da construção civil: uma abordagem ambiental. EDIPUCRS, 2009.

[8] SIMONETTO, Eugênio et al. Simulação Computacional para Avaliação de Cenários sobre a Reciclagem de Papel e seus Possíveis Benefícios. Sistemas \& Gestão, [s.l.], v. 9, n. 1, p.48-58, 2014. LATEC. http://dx.doi.org/10.7177/sg.2014.v9.n1.a5. Disponível

https://doi.org/10.7177/sg.2014.V9.N1.A5>. Acesso em: 05 mar. 2018.

[9] TSUTIYA, M. T. Abastecimento de água: Departamento de Engenharia Hidráulica e Sanitária da Escola Politécnica da Universidade de São Paulo, 643p. São Paulo, 2006.

[10] PENNER, Giovanni Chaves; DIAS, Ana Gabriela Santos; JUNIOR, Laércio dos Santos Rosa. AVALIAÇÃO DOS MÉTODOS DE PROJEÇÃO POPULACIONAL PARA ELABORAÇÃO DE PROJETOS DE SANEAMENTO BÁSICO EM BELÉM DO PARÁ. Congresso ABES, 2017.

[11] RÊGO, Giovanni Silva. O uso do ciclo PDCA na gestão de resíduos de serviços de saúde da unidade II de uma instituição filantrópica no município de Natal/RN. Encontro Internacional sobre Gestão Empresarial e Meio Ambiente - ENGEMA, 2012.

[12] BUENO, Monise Carla. 7 práticas para diminuir os resíduos na construção civil. 2015. Disponível em: $\quad<$ https://certificacaoiso.com.br/7-praticas-para-diminuir-os-residuos-e-aumentar-o-lucro-naconstrucao-civil/>. Acesso em: 30 abr. 2018.

[13] ARAÚJO, Marcos Antônio da Silva. Estudo de um layout de um canteiro de obra da construção de uma edificação residencial multifamiliar com base no modelo Systematic Layout Planning. Especialize, João Pessoa, v. 01/2015, n. 10, p.01-18, 09 jun. 2015. Disponível em: <https://www.ipog.edu.br/revistaespecialize-online/edicao-n10-2015/estudo-de-um-layout-de-um-canteiro-de-obra-da-construcao-deuma-edificacao-residencial-multifamiliar-com-base-no-modelo-systematic-layout-planning/>. Acesso em: 01 maio 2018.

[14] Ministério das Cidades. Programa Brasileiro da Qualidade e Produtividade do Habitat. 2017. Disponível em: <http://pbqp-h.cidades.gov.br/pbqp_apresentacao.php>. Acesso em: 01 maio 2018.

[15] SOUZA, Ioneide Nunes Carvalho. IMPACTOS CAUSADOS PELOS RESÍDUOS PROCEDENTES DA CONSTRUÇÃO CIVIL E DEMOLIÇÃO: UMA ANÁLISE CONCEITUAL DOS PROCEDIMENTOS PARA MINIMIZÁLOS. 2017.2 Disponível em: <https://semanaacademica.org.br/system/files/artigos/impactos_causados_pelos_residuos_procedentes_ da_construcao_civil_e_demolicao_uma_analise_conceitual_dos_procedimentos_para_minimiza_los.pdf $>$. Acesso em: 01 maio 2018.

[16] INFONET. Aracaju tem 300 pontos de descarte irregular de resíduos: Força Tarefa quer coibir descarte irregular de resíduos. 2015. Elaborado por VERLANE ESTÁCIO. Disponível em: <http://www.infonet.com.br/noticias/cidade//ler.asp?id=167645>. Acesso em: 01 abr. 2018. 
[17] PRIMO, Aislan Silva et al. Estimativa da Capacidade de Compactação e vida útil do Aterro sanitário que atende a cidade de Aracaju. Semana de Pesquisa da Universidade Tiradentes-SEMPESq, n. 18, 2018.

[18] FIESP. NA FIESP, HOLANDA MOSTRA SUA EXPERIÊNCIA SOBRE GERENCIAMENTO DE RESÍDUOS SÓLIDOS. 2012. Disponível em: <http://www.fiesp.com.br/noticias/na-fiesp-holanda-mostra-suaexperiencia-sobre-gerenciamento-de-residuos-solidos/>. Acesso em: 01 maio 2018.

[19] NIE - Núcleo de Informações Econômicas da Federação das Indústrias do Estado de Sergipe. Em março, o custo da construção chegou a $\mathrm{R} \$ 939,03$ por $\mathrm{m}^{2}$, em Sergipe. 2018. Disponível em: $<$ http://nie.fies.org.br/conteudo/1/2959/em-marco,-o-custo-da-construcao-chegou-a-r-939,03-por-m,em-sergipe.html>. Acesso em: 01 maio 2018.

[20] BRASILENGENHARIA (Org.). Reciclagem de materiais reduz em até 25\% o custo da obra. 2012. Disponível em: <http://www.brasilengenharia.com/portal/construcao/1463-reciclagem-de-materiaisreduz-em-ate-25-o-custo-da-obra>. Acesso em: 01 maio 2018.

[21] LIMA, Rosimeire S.; LIMA, Ruy Reynaldo R. Guia para elaboração de projeto de gerenciamento de resíduos da construção civil. Série de Publicações Temáticas do Crea-PR. Curitiba: Crea, 2012. 


\section{Capítulo 2}

Microdrenagem sustentável: Avaliação do escoamento superficial urbano no município de Aracaju/SE

\section{Érica de Souza Viana \\ Neuma Rúbia Figueiredo Santana}

Resumo: As estruturas que constituem o sistema de drenagem urbana têm fundamental importância para o bom desempenho do meio urbano. Este trabalho tem o objetivo de verificar o escoamento superficial em alguns bairros do município de Aracaju/SE e a sustentabilidade do sistema de drenagem ofertado a população que foi elaborado em quatro etapas, que foram levantamento bibliográfico, informações no Corpo de Bombeiros e Defesa Civil, visita aos bairros e coleta direta de dados, com formulário de entrevista semiestruturado, onde os moradores da localidade puderam opinar quanto ao sistema de drenagem, infraestrutura dos bairros, a existência dos pontos de alagamento e sua frequência, a causa das enchentes e a melhoria por ordem de prioridade. Desta maneira, apresentam-se soluções alternativas que seriam a elaboração de uma proposta de reformulação nas legislações municipais e estaduais, no caso o plano diretor urbano, para implantar a drenagem sustentável, recomendando que os órgãos públicos obriguem os condomínios a implantarem os pavimentos permeáveis nas calçadas e áreas descobertas que não exerçam influência estrutural e além dessa opção, pode-se investir na conscientização da nova geração de engenheiros, arquitetos e projetistas podem contribuir no planejamento em espaços mais sustentáveis, tendo em vista o crescimento da população.

Palavras-chave: Drenagem urbana, pavimentos permeáveis, sustentabilidade 


\section{INTRODUÇÃO}

A Drenagem Urbana Sustentável, que na Engenharia Civil está contemplada na esfera do Saneamento Básico é assunto cada vez mais presente atualmente, de modo a viabilizar o retardamento e o tratamento das águas das enxurradas.

As enchentes urbanas constituem um dos maiores impactos ambientais sobre o meio urbano e os efeitos produzidos pelo avanço desordenado da urbanização se refletem na falta de planejamento do uso e ocupação do solo.

Um dos fatores da desordem do sistema é agravada pela ausência de Planos Diretores de Drenagem e Desenvolvimento Urbano. Para Dias e Antunes (2011), diante das frequentes enchentes surge a necessidade de serem projetados sistemas de drenagem mais eficientes, com adoção de medidas sustentáveis. Aumentar, apenas, a capacidade de escoamento das redes necessita de um alto investimento e, em condições meteorológicas extremas, pode ser que não solucione o problema como um todo, nem mesmo a longo prazo.

O modelo de drenagem convencional não viabiliza soluções de forma individual e foi através de mecanismos e políticas públicas integrando planejamento e drenagem urbana que surgiram novas práticas para substituir e complementar o sistema clássico de drenagem, apresentando assim, uma alternativa para reduzir a ocorrência de enchentes e inundações urbanas propondo soluções sustentáveis para o desenvolvimento urbano.

Este trabalho expôs práticas de drenagem sustentável para a diminuição do escoamento superficial nas zonas urbanas. Onde primeiramente foi realizado um levantamento acerca do ciclo hidrológico, na sequência foi estudado o planejamento urbano e plano diretor, partindo para o sistema de drenagem urbana, posteriormente relatando os impactos ambientais causados pelas enchentes e inundações. Em seguida foram apresentados os itens de drenagem sustentável e pavimento permeável, que foram a parte fundamental do estudo.

O objetivo geral foi verificar o escoamento superficial em alguns bairros do município de Aracaju/SE e a sustentabilidade do sistema de drenagem ofertado aos aracajuanos.

\section{METODOLOGIA}

0 estado de Sergipe é, das 27 unidades federativas, o menor estado brasileiro em área territorial. Está localizado na região Nordeste, é banhado a leste pelo Oceano Atlântico e faz fronteira com ao norte com o estado de Alagoas e ao sul e oeste com o estado da Bahia. Ocupa uma área total de $21.918,44 \mathrm{~km}^{2}$ e uma população de 2.068.017, com uma média de 94,36 habitantes por metro quadrado. Possui 75 municípios. (IBGE, 2017)

A área de estudo, está localizada no maior município em população, Aracaju, capital do Estado, cujas

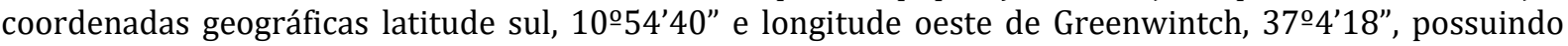
uma altitude de 4,9 m, limita-se com os municípios de São Cristóvão, Nossa Senhora do Socorro, Santo Amaro das Brotas, Barra dos Coqueiros e Itaporanga D’Ajuda. (Figura 1).

A pesquisa de campo foi realizada no Município de Aracaju e para sua realização foi abordada a temática referente a drenagem urbana, saneamento básico e os impactos ambientais que a chuva tem causado no município citado.

0 trabalho foi elaborado em quatro etapas, a primeira utilizou-se da realização de um levantamento bibliográfico acerca do tema de drenagem sustentável e pavimentos permeáveis através de livros, revistas, artigos, dissertações de mestrado, teses de doutorado e sites; em seguida houve uma pesquisa secundária com coleta de dados e informações nos órgãos que tratam sobre o controle de alagamentos e inundações no Estado de Sergipe e no município de Aracaju, o Corpo de Bombeiros e Defesa Civil, a partir de então foram escolhidos os bairros Novo Paraíso, Farolândia, Treze de Julho, Cidade Nova e Centro, pelo fato de que os órgãos citados acima apontaram estes como zonas de alagamento e inundações, e que há muito sofrem com esse tipo de evento que causa transtornos à população.

A terceira etapa foi visitar os locais destacados, analisar e verificar os pontos de alagamento nas regiões indicadas.

O quarto e último passo foi a coleta direta de dados, na qual se elaborou um formulário de entrevista semiestruturado, que teve como objetivo diagnosticar e analisar a caracterização socioeconômica e 
ambiental das comunidades, identificando a deficiência do serviço de drenagem que é oferecido a população, contendo quinze perguntas objetivas a respeito do sistema de drenagem, causa das enchentes, tubulações para escoamento de águas de chuva, pontos de alagamento e infraestrutura dos locais estudados, sendo constituído com a busca das informações em campo. Nestas entrevistas, buscou-se com a população, os pontos que frequentemente ocorrem os fenômenos de alagamentos e inundações urbanas.

Figura 1: Mapa do Brasil, com destaque para Sergipe e Aracaju

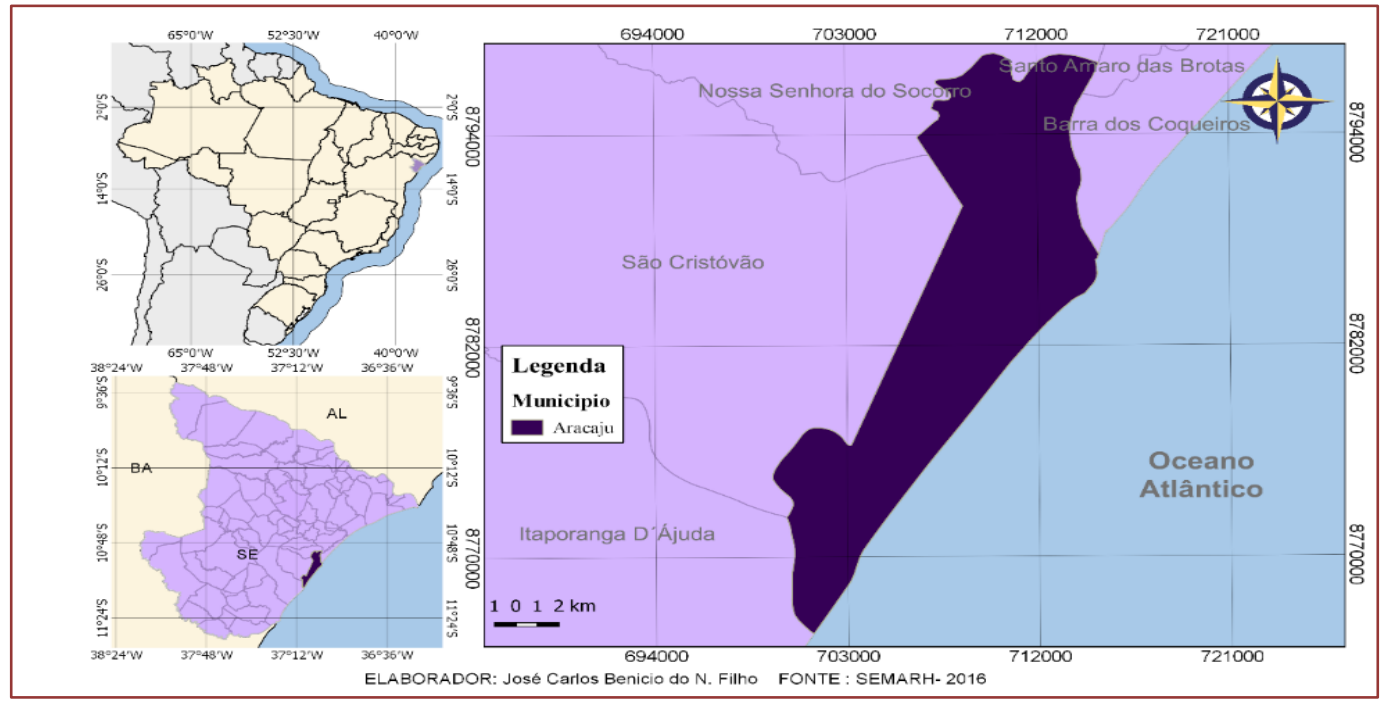

Fonte: SEMARH, 2016

Ao todo foram aplicados 77 formulários, sendo 23 no Novo Paraíso, 15 na Farolândia, 14 na Treze de Julho, 11 na Cidade Nova e 14 no Centro da cidade de Aracaju.

A coleta de dados e registros fotográficos foram realizados no período de 21 a 26 de outubro de 2017 . As características observadas nos bairros foram: Ruas com e sem pavimentação, com e sem meio fio, com sistema de microdrenagem e/ou macrodrenagem, ruas/avenidas com ou sem alagamento.

A análise dos dados deu-se pela tabulação dos dados levantados através da aplicação dos questionários às comunidades e, posteriormente, foram elaborados gráficos e/ou Tabelas utilizando o programa Excel, da Microsoft, para melhor visualização e interpretação dos resultados.

A tabulação dos dados gerou gráficos e Tabelas que auxiliaram na análise através de cruzamentos de todas as variáveis levantadas. Com a realização da pesquisa foi possível obter um diagnóstico das condições reais do serviço de drenagem urbana das águas pluviais dos bairros, dados sobre o quadro das e condições ambientais, definindo níveis de criticidade das áreas, disponibilizando os dados obtidos sugerindo possíveis medidas preventivas e mitigadoras ao poder público municipal.

\section{RESULTADOS E DISCUSSÃO}

A avaliação do eixo social das variáveis: tempo de moradia no domicílio e número de pessoas por domicílio apontou os seguintes resultados descritos nas figuras 2 e 3. Segundo o IBGE (2010), hoje no Brasil existem, cerca de 57,3 milhões domicílios considerados particulares e permanentes, o que há dez anos eram 44,7 milhões, aumentando em quase $28 \%$, mais que o dobro da expansão da população brasileira que, no mesmo período, cresceu 12,3\%, de 169,8 milhões para 190,7 milhões. De acordo com o gráfico de tempo de moradia no município (Figura 2), é possível identificar que a maior parte da população entrevistada, cerca de 49\%, tem mais de 15 anos que é residente da área estudada. A figura 3, mostra que $34 \%$ da amostra da população tem 1 ou 2 pessoas residentes no domicílio. 
Figura 2: Gráfico do tempo de moradia no município

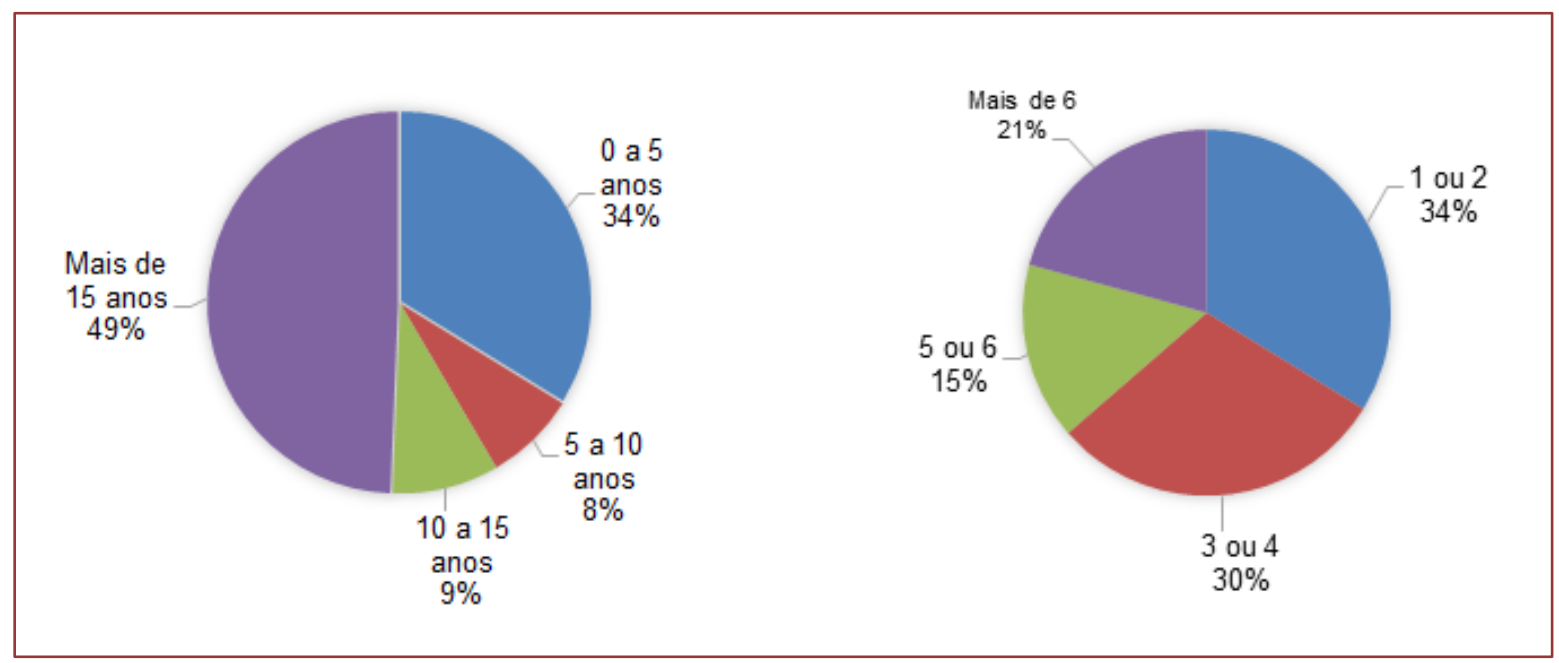

Fonte: Acervo pessoal, 2017
Figura 3: Gráfico do número de habitantes por domicílio

Os dados obtidos por meio das entrevistas, notou-se que nos bairros Novo Paraíso e Farolândia a população mora há mais de 15 anos na zona estudada, e que nesses mesmos bairros a quantidade de moradores por domicílio é de 1 ou 2 pessoas. Pode-se analisar diante das entrevistas que como a comunidade destas áreas possuem muito tempo de moradia, foi possível adquirir mais informações a respeito dos serviços de saneamento básico oferecidos pelo poder público.

De acordo com o IBGE (2010), em Aracaju, a média de moradores em domicílios particulares ocupados é de 3,36. Nesta pesquisa foi possível observar que o número de habitantes por domicílio variava entre 1 e 4 pessoas, estando entre a estimativa apontada pelo IBGE, sendo maior porcentagem para uma ou duas pessoas por residência.

A verificação da presença e andamento do sistema de drenagem urbana das águas pluviais deve ser iniciada pela microdrenagem, representada pelas pequenas e médias galerias, bocas de lobo e bueiros, ruas pavimentadas, sarjetas e meio-fio encarregados pela coleta e transporte das águas pluviais até o ponto de lançamento que podem ser os canais, córregos ou rios (MONTES e LEITE, 2009). Nesta pesquisa observou-se deficiências nas medidas estruturais e não estruturais como podem ser observadas nas Figuras 4 e 5.

A pesquisa in loco mostra que o meio ambiente nas zonas de escoamento natural das águas pluviais vem sendo degradado em consequência da precariedade na cobertura do serviço de coleta de lixo, que ocasiona a disposição de rejeitos nessas áreas. Além da ineficiência do serviço de coleta de lixo, existe o descaso por parte dos moradores com o ambiente. Observou-se que em alguns locais, mesmo quando o tempo está estiado, há presença de resíduos sólidos nas áreas de entorno das bocas de lobo e bueiros.

Para Canholi (2005), no Brasil tem surgido e/ou aumentando os problemas de inundações especialmente do rápido crescimento da população urbana, do baixo nível de entendimento do problema, da falta de existência de planos de longo prazo, do uso deficiente de medidas não estruturais e da manutenção inapropriada dos sistemas de controle de cheias.

As ações do manejo e gestão dos resíduos sólidos no Brasil abrangem as esferas ambiental, social e econômica. A Lei no 12.305 da Política Nacional de Resíduos Sólidos foi desenvolvida com o intuito de proporcionar diversas alterações no cenário dos resíduos (CEMPRE, 2013). Através de políticas que preconizam o descarte adequado dos resíduos sólidos, espera-se que passe a haver menor descarte dos resíduos de forma inadequada e que estes se tornem mais raros na rede de drenagem urbana.

Além disso, drenagem e resíduos sólidos são pilares do saneamento básico, conforme a Lei Federal do Saneamento Básico - Lei 11.445/07 que trata sobre o conjunto de serviços de abastecimento público de água potável; coleta, tratamento e disposição final adequada dos esgotos sanitários; drenagem e manejo das águas pluviais urbanas, além da limpeza urbana e o manejo dos resíduos sólidos. 
Figura 4: Drenagem no bairro Farolândia

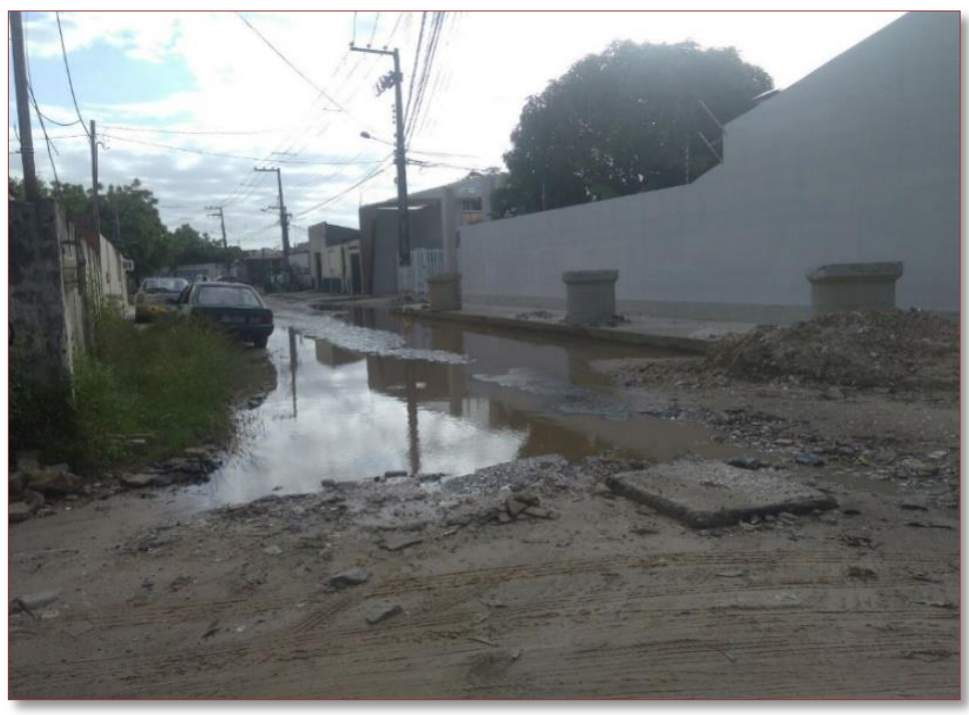

Fonte: Acervo Pessoal, 2017

Figura 5: Drenagem no bairro Centro

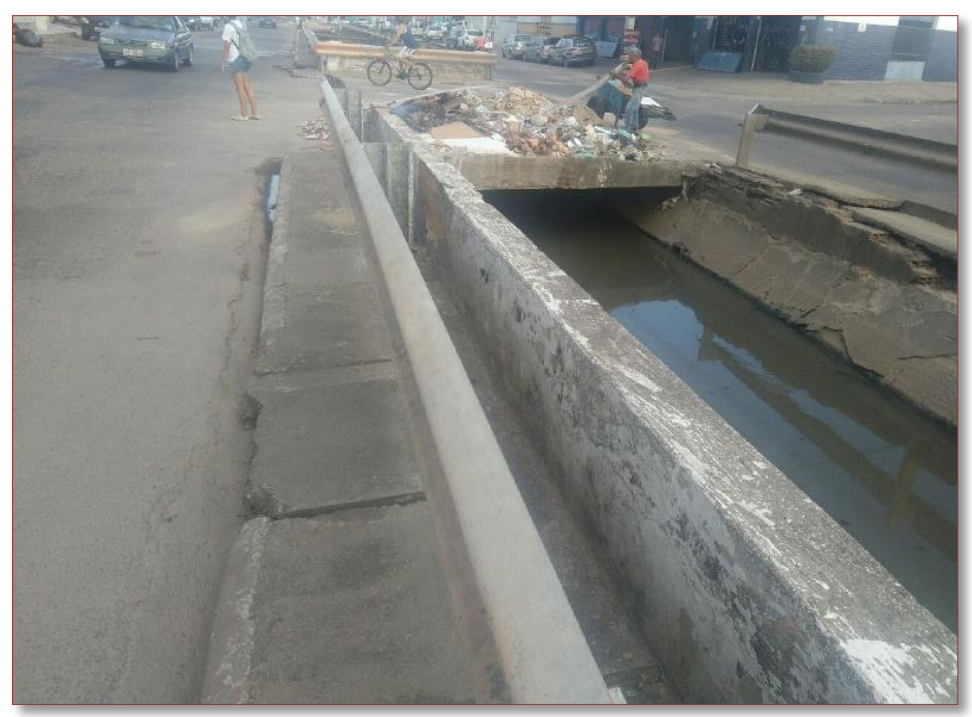

Fonte: Acervo pessoal (2017)

Analisando-se, de acordo com as entrevistas feitas aos moradores, que os residentes dos bairros estudados, estatisticamente, não aprovam o sistema de drenagem de águas pluviais, pois dos 77 formulários aplicados, apenas $23 \%$ opinaram que existe sistema de drenagem no município, 4\% não sabem responder, 8\% consideram que existe de forma parcial e $65 \%$ dos entrevistados consideram que não há sistema de drenagem no município. (Figura 6). 
Figura 6: Gráfico da opinião dos moradores quanto ao sistema de drenagem

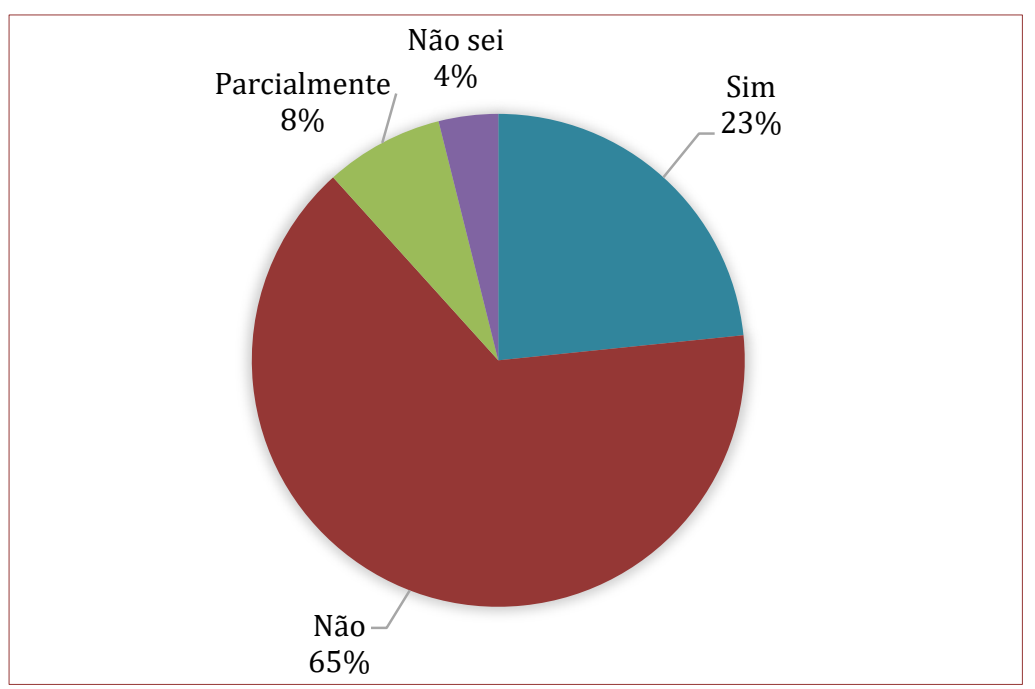

Fonte: Acervo pessoal (2017)

O estudo apontou que no bairro Novo Paraíso, o índice de insuficiência da drenagem é o mais alto, pois $87 \%$ dos moradores avaliaram que não existe sistema de drenagem como pode ser observado na Tabela 1. Em contrapartida, o bairro que apresentou maior índice de satisfação foi o bairro Treze de Julho, apresentando uma parcela de $57 \%$ de aprovação e existência do sistema de drenagem urbana.

Tabela 1: Opinião dos moradores quanto a existência do sistema de drenagem por bairro

\begin{tabular}{|c|c|c|c|c|}
\hline Bairro / Porcentagem (\%) & \multicolumn{1}{c}{ Sim } & Não & Parcialmente & Não sei \\
\hline Novo Paraíso & $9 \%$ & $87 \%$ & $4 \%$ & $0 \%$ \\
\hline Farolândia & $13 \%$ & $80 \%$ & $7 \%$ & $0 \%$ \\
\hline Treze de Julho & $57 \%$ & $14 \%$ & $14 \%$ & $14 \%$ \\
\hline Cidade Nova & $27 \%$ & $55 \%$ & $9 \%$ & $9 \%$ \\
\hline Centro & $21 \%$ & $71 \%$ & $7 \%$ & $0 \%$ \\
\hline \multicolumn{7}{l}{ Fonte: Acervo Pessoal (2017) } \\
\end{tabular}

O sistema de drenagem urbana do município de Aracaju é administrado diretamente pelo poder público e coordenado pela Empresa Municipal de Obras e Urbanização (EMURB), por meio da Diretoria de Operações, sendo responsável pela investigação dos pontos de obstrução dos aparelhos de drenagem, fazendo a limpeza da macro e micro drenagem através de trabalhos nos canais, bocas de lobo, bueiros tendo o papel de substituir todas as tubulações que estejam danificadas.

De acordo com a EMURB, o sistema de drenagem adotado é do tipo separador absoluto, que consiste em um conjunto de infraestruturas e instalações operacionais que visam coletar, transportar, tratar e dispor de forma adequada os esgotos sanitários, considerando aspectos ambientais e de saúde pública. Porém, o município recebe alguns esgotos anteriormente tratados, tanto das residências quanto das indústrias de geradores que tenham a autorização da Administração Estadual de Meio Ambiente - ADEMA, mas ainda assim, a EMURB reconhece e entende que há uma parcela de esgoto sem tratamento ligada a rede de drenagem de forma clandestina.

O sistema separador absoluto, para seu perfeito funcionamento, depende de fiscalização efetiva e controle eficiente, para se evitar que ligações clandestinas encaminhem águas pluviais, principalmente, as provenientes de telhados e pátios dos domicílios atendidos veiculam em um sistema independente do sistema de drenagem de águas pluviais. Notoriamente, no Brasil, esta fiscalização é praticamente nula. 
De acordo com os dados observados, foi possível constatar que o sistema separador absoluto não é o mais eficaz no município, sendo possível identificar que a população tem a consciência que a rede de esgoto está interligada com as águas pluviais de forma clandestina, pois mais de $50 \%$ da população opinou que sim, cerca de $36 \%$ acredita que os sistemas não estão relacionados, uma média de 3,9\% acha que está parcialmente interligado e 9,09\% não tem opinião formada, conforme exposto na figura 7 .

Figura 7: Gráfico da opinião sobre ligação de águas pluviais e esgoto

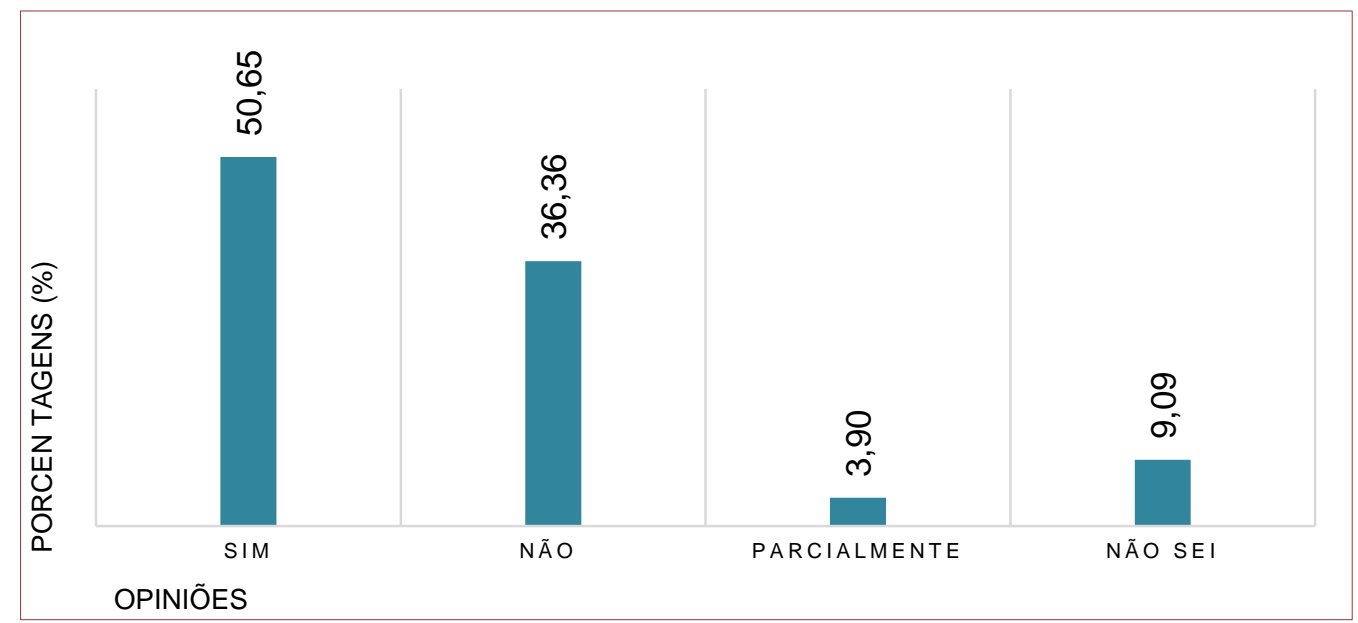

Fonte: Acervo pessoal (2017)

O Projeto de Lei (PL) que regula o Plano Municipal de Saneamento Básico, foi sancionado pelo prefeito no dia 22 de novembro de 2017, com o propósito de levar esgotamento sanitário, abastecimento de água,9 drenagem, limpeza urbana e manejo de resíduos sólidos para toda a capital atendendo a Lei Federal $\mathrm{n}^{\circ}$ 11.445/05, que obriga os municípios a executar um plano de saneamento, desta forma o plano irá dispor de recursos federais para que o poder público municipal possa investir em melhorias para a cidade.

A aprovação está dentro do prazo estipulado pelo Governo Federal, que determinou que os municípios que deveriam aprovar seus planos municipais de saneamento básico até janeiro de 2018.

Segundo a empresa municipal de obras e urbanização, o município não possui nenhum instrumento que regule o sistema de drenagem, mas afirma que todos os projetos de drenagem são analisados de acordo com as Normas Brasileiras de drenagem para a aprovação dos projetos que são requeridos.

Conforme a opinião dos entrevistados, a condição (qualidade) da infraestrutura (estrutura da boca de lobo, meio fio e pavimentação), onde as respostas poderiam ser ótima, boa, ruim ou péssima e o resultado foi bastante negativo, por que a maior parcela dos moradores, considerou os itens perguntados como ruim ou péssimo. Quanto a estrutura da boca de lobo, $67,53 \%$ considerou como péssima e $27,27 \%$ achou que a condição era ruim, somados, os valores resultam em 94,84\%. Em relação a condição do meio fio e pavimentação asfáltica nenhum morador declarou que o estado era ótimo, sendo para as guias de meio fio $15,58 \%$ boa, 32,47\% ruim e 51,95\% péssima, que somados ruim e péssimo totalizou $84,42 \%$ e para a pavimentação asfáltica $16,88 \%$ boa, $16,88 \%$ ruim e $66,23 \%$ péssima, com a soma negativa em $83,11 \%$. Como é possível observar nas figuras 8, 9 e 10, representadas pelos gráficos e registros fotográficos. 
Figura 8: Gráfico da opinião da infraestrutura dos bairros

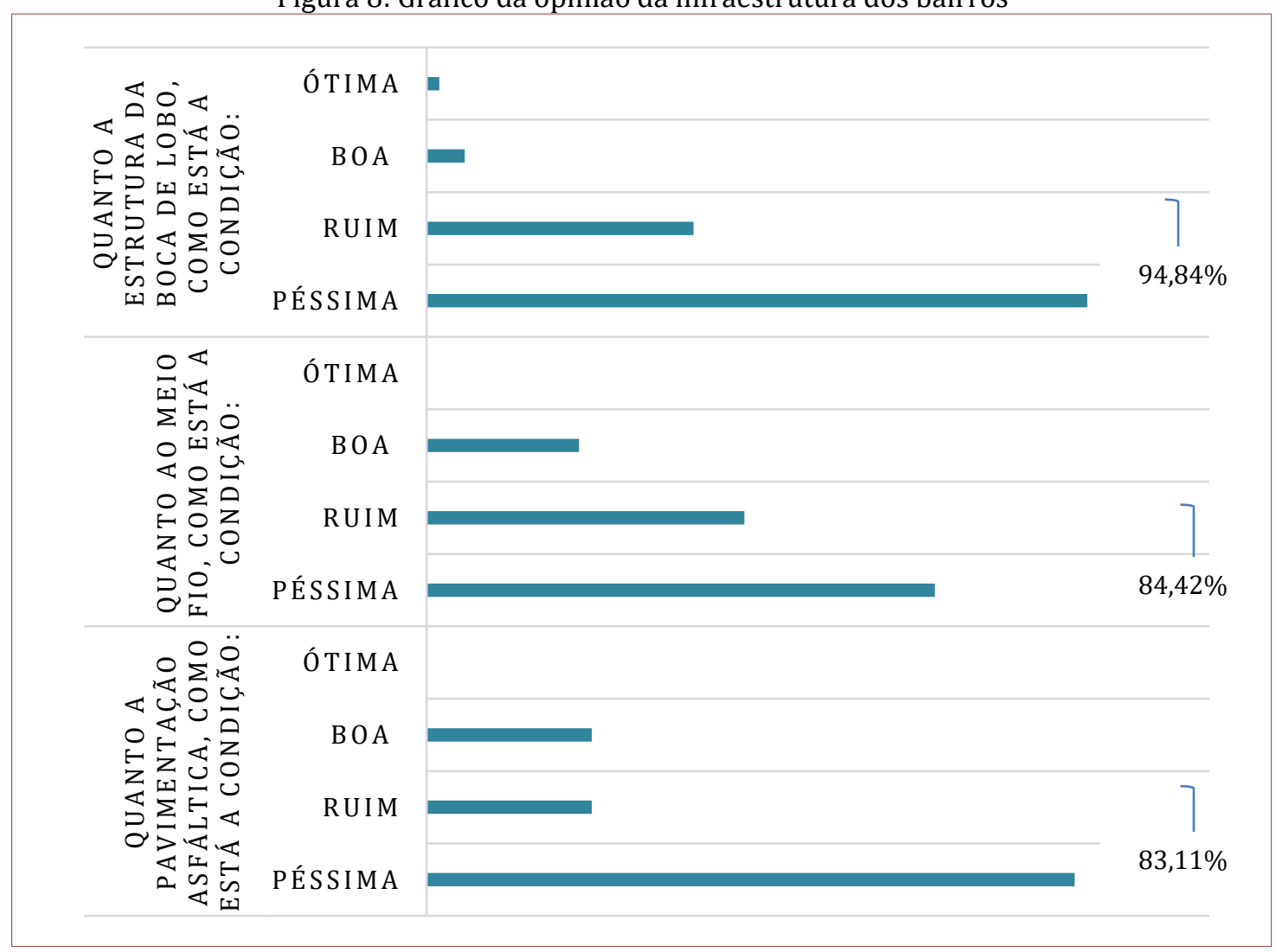

Fonte: Acervo Pessoal (2017)

Para Tucci (1997), a população urbana aumentou significativamente durante as últimas décadas acelerando esta urbanização após a década de 60 e a partir de então, foi sendo gerada uma população urbana com infraestrutura inadequada e os efeitos podem ser sentidos sobre todo o aparelhamento urbana relativo aos recursos hídricos tais como abastecimento de água, transporte e tratamento de esgotos cloacal e pluvial.

Figura 9: Estrutura da boca de lobo no bairro Cidade Nova

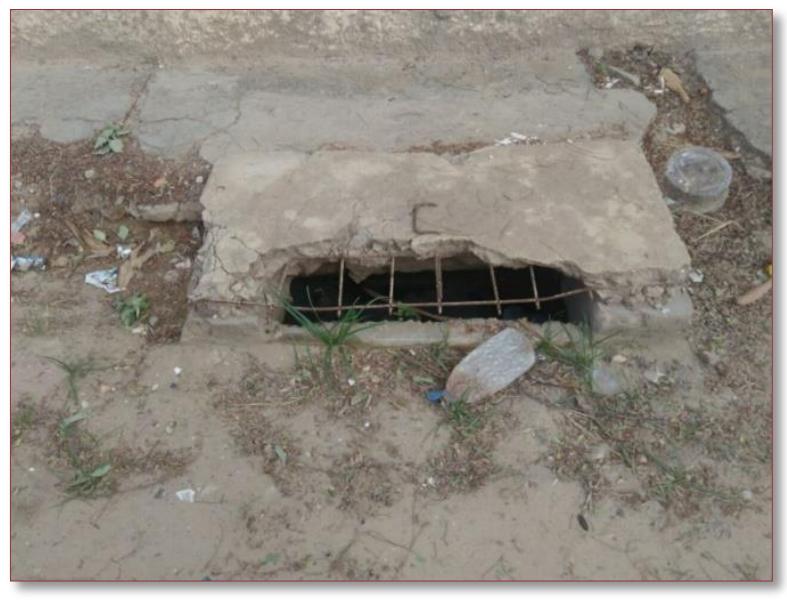

Fonte: Acervo pessoal (2017) 
Figura 10: Estrutura do meio fio no bairro Centro

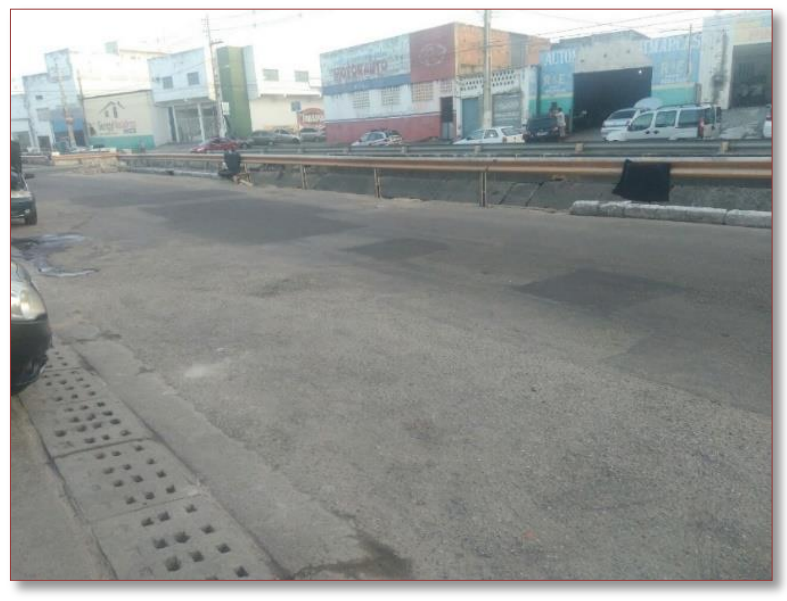

Fonte: Acervo pessoal (2017)

O IBGE (2010) evidencia que embora a pavimentação das vias urbanas seja um elemento que melhora a circulação interna nas cidades, a impermeabilização dos solos pode gerar problemas de erosão, assoreamentos, alagamentos, inundações e proliferação de vetores de problemas de saúde pública.

Tucci (2002) é categórico em afirmar que os alagamentos se encontram entre os problemas urbanos que se evidenciam por uma alta frequência e gravidade por causa da impermeabilização e ocupação do solo, drenagem inadequada, aterros, fatores que produzem obstruções ao escoamento, e são responsáveis por grande proporção de danos à infraestrutura local, às habitações e às condições de vida das comunidades e das sociedades de baixa renda.

Através das entrevistas, foi possível identificar que em Aracaju, há vários pontos de alagamento nos bairros estudados, como pode ser visto nas figuras 11 e 12, onde é exposto que 94\% da população opinou que há pontos de alagamento na rua ou bairro em que mora, $88 \%$ da população informou que ocorre alagamento mais de uma vez por ano, e em muitos casos alegando que em todos os períodos de chuva, acontecem as inundações.

Durante o período do trabalho, foram tiradas algumas fotografias que registraram os pontos de alagamento nos dias de chuva intensa no município de Aracaju como pode ser observado nas figuras 13, 14 e 15.

Figura 11: Gráfico da existência dos pontos de alagamento

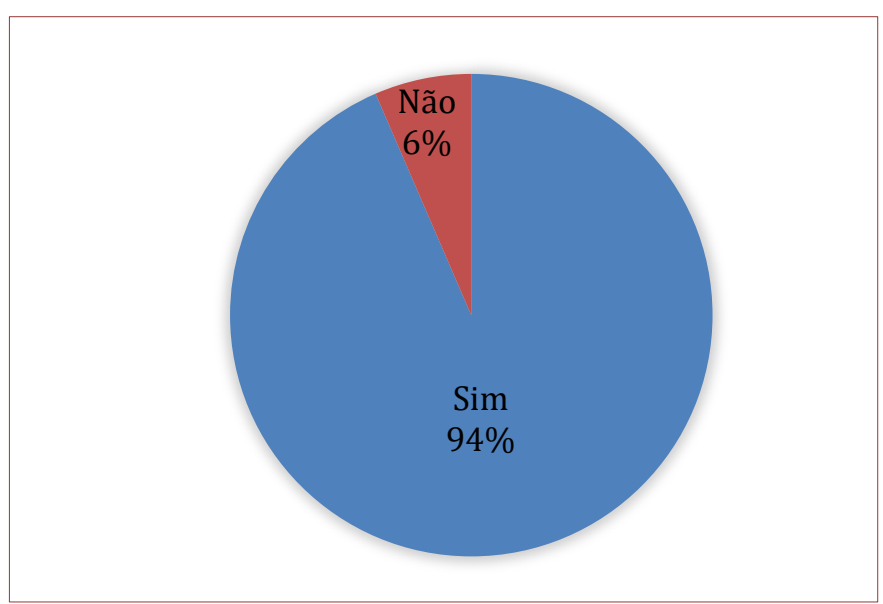

Fonte: Acervo Pessoal (2017) 
Figura 12: Gráfico da frequência de alagamentos

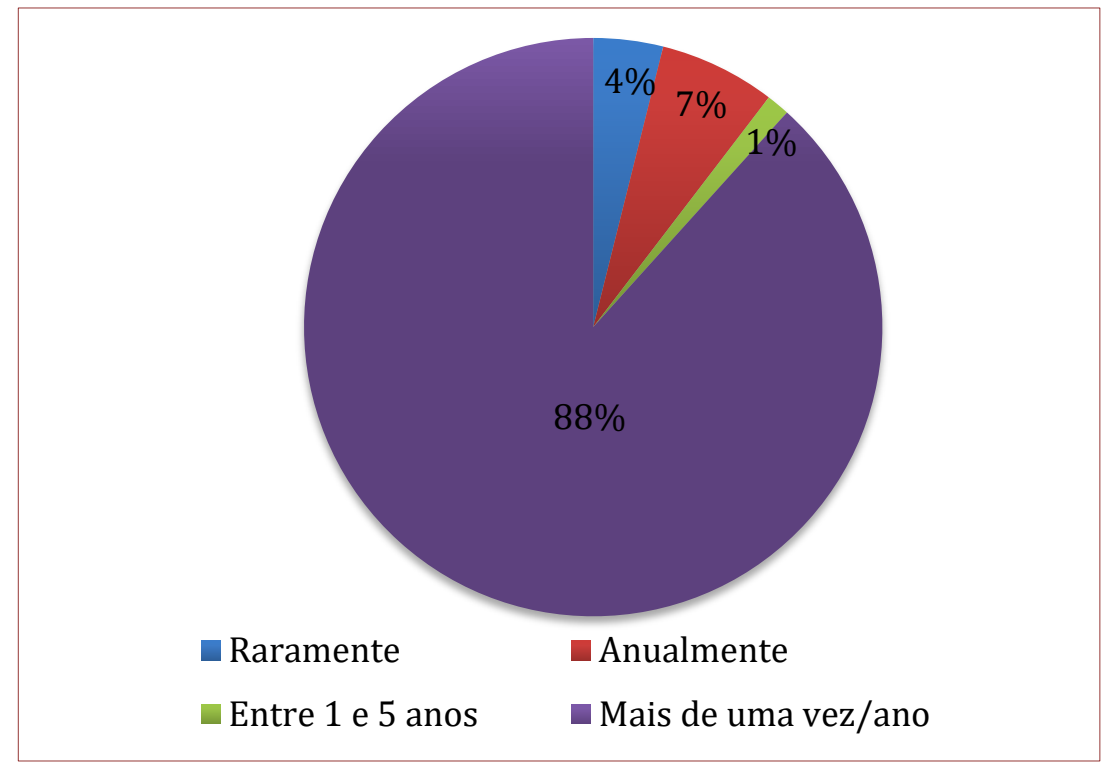

Fonte: Acervo Pessoal (2017)

Figura 13: Ponto de alagamento no bairro Novo Paraíso
Figura 14: Ponto de alagamento no bairro Centro

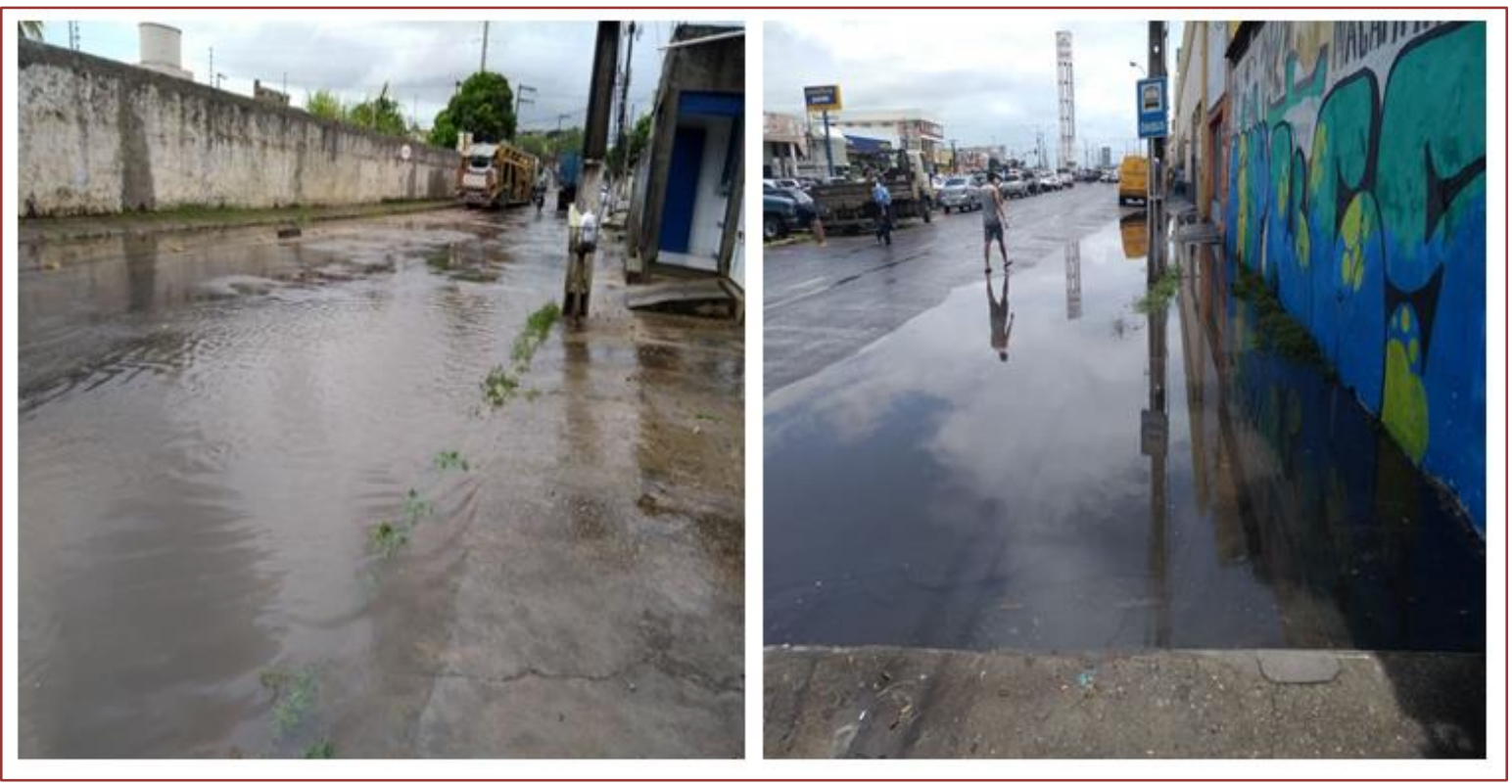

Fonte: Acervo pessoal (2017) 
Figura 15: Ponto de alagamento no bairro Cidade Nova

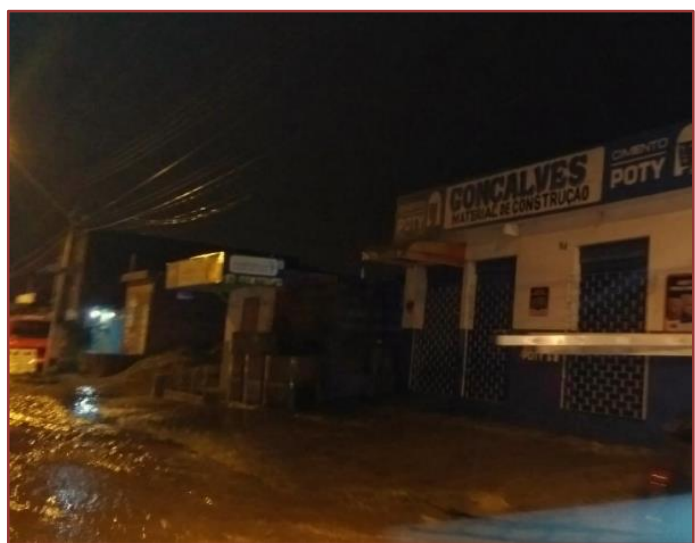

Fonte: Acervo pessoal (2017)

Os principais tipos de enchentes urbanas nas cidades brasileiras são devido a urbanização, produzidas pela impermeabilização dos solos; ocupação das áreas ribeirinhas que são o caso das enchentes naturais e devido a problemas localizados produzidos através de obstruções ao escoamento e projetos inadequados. (TUCCI, 1997)

O funcionamento do sistema de drenagem urbana em Aracaju é dificultado por alguns inconvenientes que a própria população local comete, tais como acúmulo de lixo na área da macrodrenagem, ocupação irregular do solo aumentando as áreas impermeáveis e a ligação clandestina de esgotos nas redes de drenagem (Figuras 16 e 17).

A figura 18, através do gráfico, mostra a opinião da população quando o assunto é a causa das enchentes urbanas, onde pode ser observa que 53\% dos moradores dos bairros estudados considera que o problema das inundações de Aracaju é a falta de planejamento urbano, em seguida a falta de consciência ambiental, representando $25 \%$ da população, $12 \%$ consideram que existem habitações imprópias, $6 \%$ julga que os alagamentos acontecem pelo desmatamento e apenas $4 \%$ consideram que as causas são de origem natural.

Figura 16: Ligação de esgoto na rede de drenagem no bairro Centro
Figura 17: Resíduos sólidos na rede de drenagem no bairro Novo Paraíso.

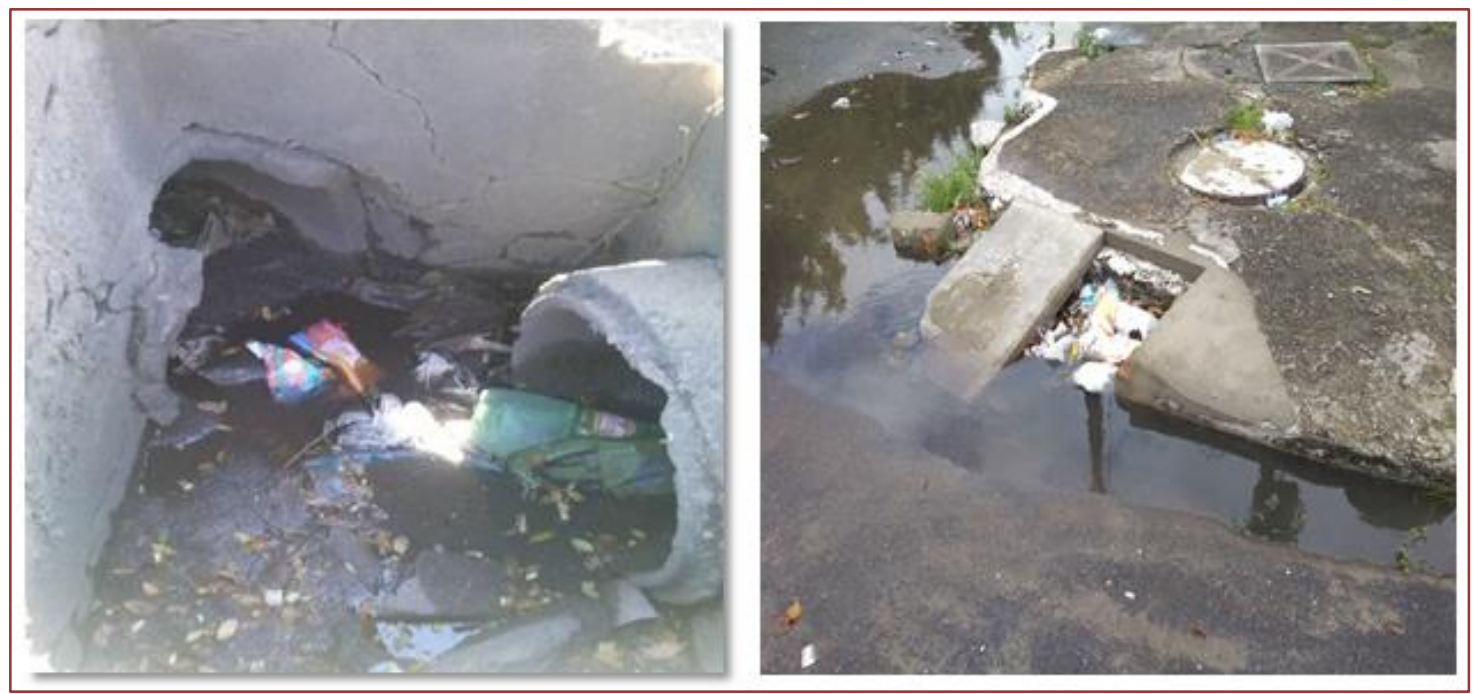

Fonte: Acervo Pessoal (2017) 
Figura 18: Gráfico de opinião dos moradores quanto a causa das enchentes

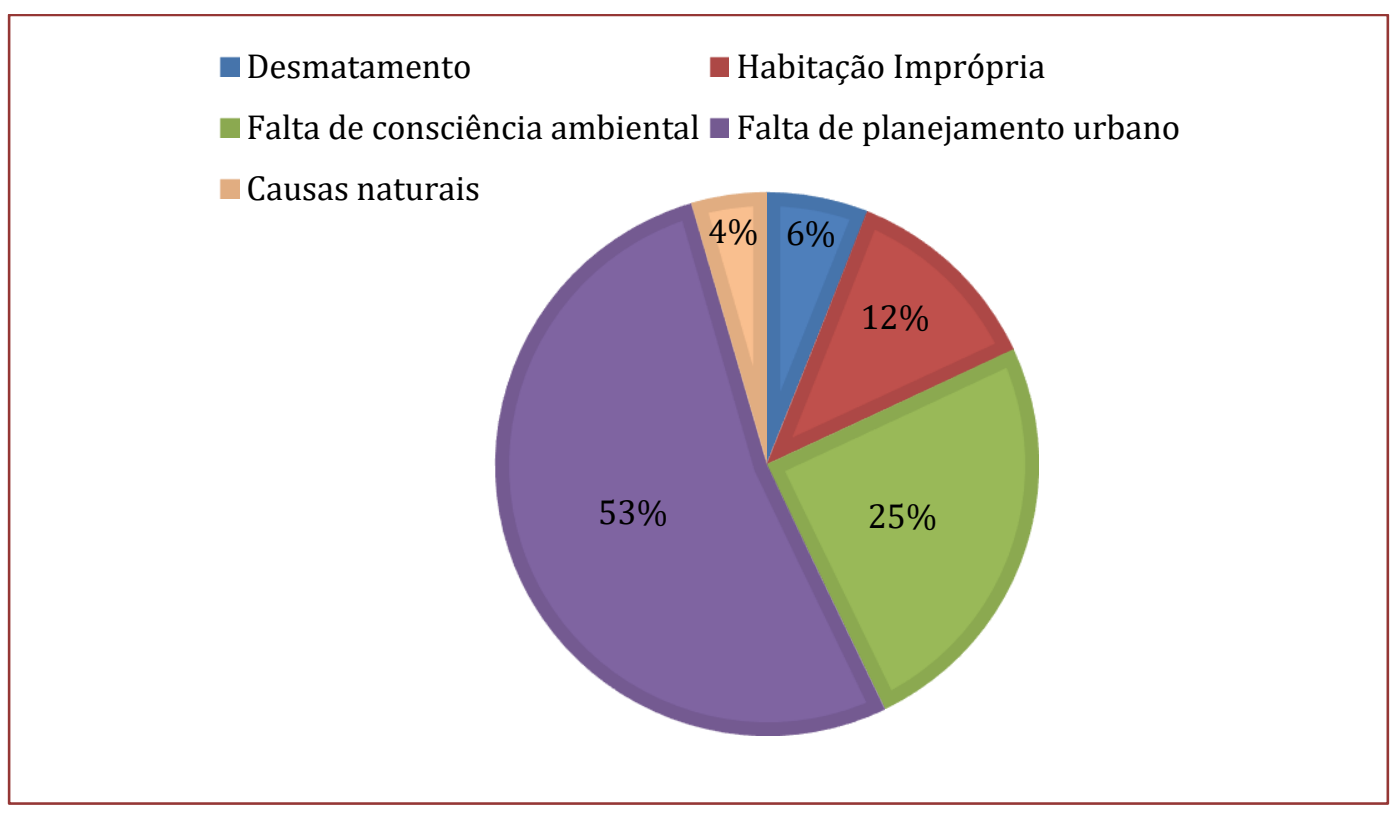

A Tabela 2, representada respectivamente pelos bairro Novo Paraíso, Farolândia, Treze de Julho, Cidade Nova e Centro, mostra que, para a população, o maior problema das causas de enchentes é a falta de planejamento urbano, exceto o bairro Centro que apresenta que 35\% dos moradores daquela região considera que as enchentes são causadas pela falta de consciência ambiental, mas logo em seguida, com $34 \%$ a falta de planejamento é citada.

Tabela 2: Tabelas da opinião dos moradores quanto a causa das enchentes por bairro

\begin{tabular}{|l|c|c|c|c|c|}
\multicolumn{1}{c|}{ Porcentagem / Bairro (\%) } & Novo Paraíso & Farolândia & $\begin{array}{c}\text { Treze de } \\
\text { Julho }\end{array}$ & $\begin{array}{c}\text { Cidade } \\
\text { Nova }\end{array}$ & Centro \\
\hline Desmatamento & $6 \%$ & $4 \%$ & $0 \%$ & $5 \%$ & $14 \%$ \\
\hline Habitação Imprópria & $6 \%$ & $11 \%$ & $5 \%$ & $27 \%$ & $14 \%$ \\
\hline Falta de consciência ambiental & $18 \%$ & $26 \%$ & $24 \%$ & $23 \%$ & $35 \%$ \\
\hline Falta de planejamento urbano & $68 \%$ & $52 \%$ & $62 \%$ & $45 \%$ & $34 \%$ \\
\hline Causas naturais & $3 \%$ & $7 \%$ & $10 \%$ & $0 \%$ & $3 \%$ \\
\hline
\end{tabular}

Fonte: Acervo Pessoal (2017)

Foi abordado junto a população, quais seriam as sugestões de melhorias, dando 3 opções que seria implantar /melhorar o sistema de esgoto, implantar/melhorar o sistema de escoamento de águas e implantar um programa de educação sanitária, onde a população tinha o livre arbítrio de escolher em que ordem seriam feitas estas implantações caso a pesquisa fosse aprovada em algum órgão público municipal conforme mostra a figura 19. 
Figura 19: Gráfico da opinião de melhoria por ordem de prioridade

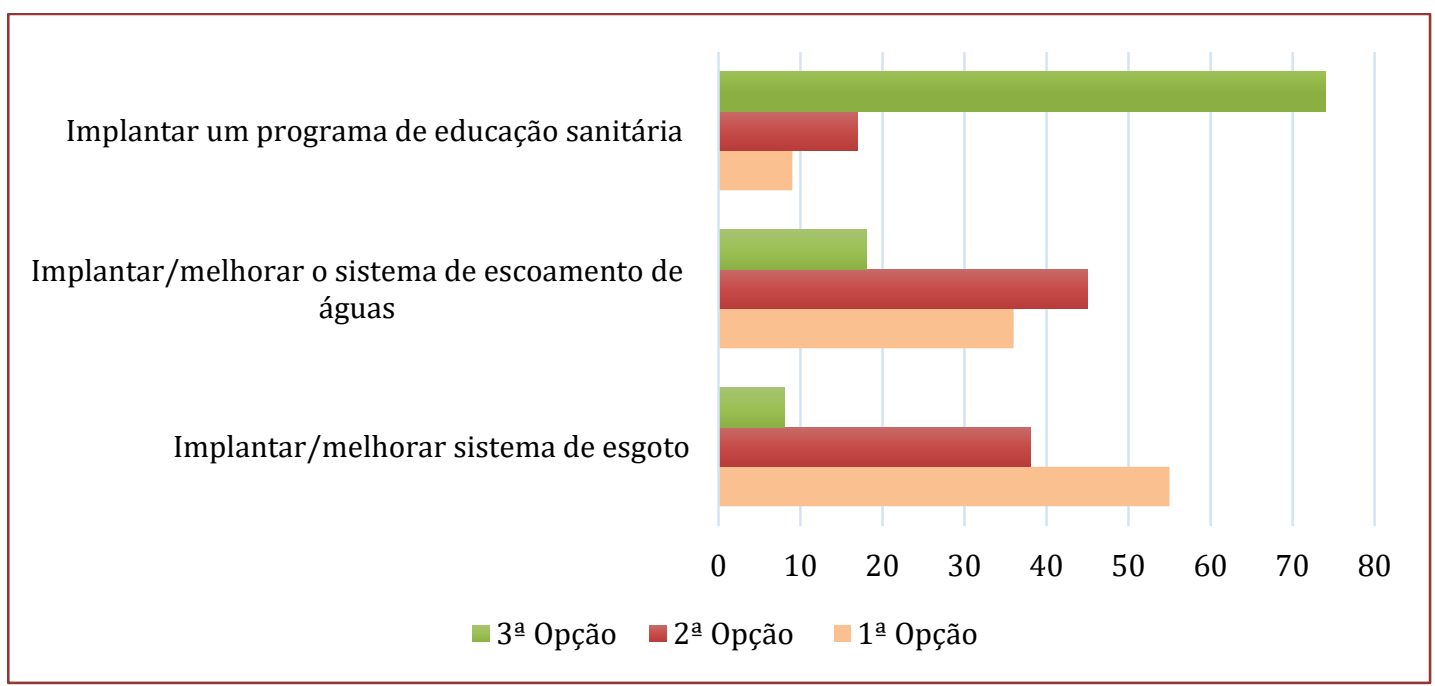

Fonte: Acervo Pessoal (2017)

\section{CONSIDERAÇÕES FINAIS}

A realidade do serviço de saneamento básico do município de Aracaju, bem como grande parte das cidades brasileiras, é ineficiente demonstrando que o poder público continua indiferente com o planejamento urbano, apesar de a legislação vigente obrigar. Os resultados obtidos apontam problemas nas áreas de estudo e que é imprescindível que principalmente, os órgãos públicos reconheçam a importância dos serviços de saneamento básico, dentre os quais o serviço de drenagem de águas pluviais está com graves problemas. A questão de se incorporar os aspectos ambientais nas ações de saneamento representa um enorme avanço, em termos legais, porém não se pode esquecer que é preciso criar condições para que os serviços de saneamento sejam implementados e sejam acessíveis a todos os brasileiros.

Existe um mapeamento de áreas suscetíveis ao risco de alagamentos, que foi elaborado pela Defesa Civil facilitando a análise, e proporcionando as autoridades competentes a oportunidade de entender os processos que envolvem os fenômenos de alagamentos urbanos, podendo planejar medidas efetivas, de forma que estes possam ser combatidos de maneira estratégica, apontando medidas preventivas e corretivas, com o intuito de amenizar os impactos causados por esses eventos adversos, porém a prefeitura do município não se manifesta para tal melhora.

As deficiências do sistema de drenagem urbana encontradas na maioria das cidades brasileiras atualmente impactam gerando graves problemas para as comunidades locais devido a ocorrência de enchentes e inundações. Esse sistema de drenagem ainda tem como modelo o escamento rápido, lançando volumes para vez maiores para a macrodrenagem, tornando-se atrasados se comparado aos avanços da urbanização e a impermeabilização do solo.

As práticas de drenagem sustentável podem ser bastante viáveis para solucionar defeitos existentes no modelo clássico, possibilitando o uso nos bairros de Aracaju. Com isso uma solução alternativa seria a elaboração de uma proposta de reformulação nas legislações municipais e estaduais, no caso o plano diretor urbano, para implantar a drenagem sustentável, recomendando que os órgãos públicos obriguem os condomínios a implantarem os pavimentos permeáveis nas calçadas e áreas descobertas que não exerçam influência estrutural. Entretanto, é necessário que as políticas públicas tenham disposição para investir no planejamento urbano fazendo com que haja a participação da sociedade. Além dessa opção, pode-se investir na conscientização da nova geração de engenheiros, arquitetos e projetistas podem contribuir no planejamento em espaços mais sustentáveis, tendo em vista o crescimento da população. 


\section{REFERÊNCIAS}

[1] BRASIL. Ministério das Cidades. Lei Nacional de saneamento básico: perspectivas para as políticas e a gestão dos serviços públicos. CORDEIRO, Berenice de Souza (Org.) Brasília, DF: Editora, 20093 v.

[2] BRASIL. LEI № 11.445, DE 5 DE JANEIRO DE 2007. Estabelece diretrizes nacionais para o saneamento básico; altera as Leis nos 6.766, de 19 de dezembro de 1979, 8.036, de 11 de maio de 1990, 8.666, de 21 de junho de 1993, 8.987, de 13 de fevereiro de 1995; revoga a Lei no 6.528, de 11 de maio de 1978; e dá outras providências. Brasília: DOU, 5 jan 2007. Disponível em:<http://www.planalto.gov.br/ccivil 03/ ato2007-2010/2007/lei/111445.htm> Acesso em: 25/09/17.

[3] CANHOLI, A. P. Drenagem Urbana e Controle de Enchentes. 2005 São Paulo - Oficina de Textos.

[4] CEMPRE. Compromisso Empresarial para a Reciclagem. Cempre Review 2013. São Paulo. 43p. 2013.

[5] DIAS, F. S.; ANTUNES, P. T. D. S. C. Estudo Comparativo de Projeto de Drenagem Convencional e Sustentável para Controle de Escoamento Superficial em Ambientes Urbanos. Curso de Engenharia Civil. Rio de Janeiro: Universidade Federal do Rio Janeiro, 2010.

[6] FUNDAÇ̃̃o ESTADUAL DO MEIO AMBIENTE: Orientações básicas para drenagem urbana- Belo Horizonte: FEAM, 2006.

[7] IBGE - Instituto Brasileiro de Geografia e Estatística. Aracaju. 2017. Disponível em: $<$ https://cidades.ibge.gov.br/brasil/se/aracaju/pesquisa/23/27652?detalhes=true $>$ Acesso em: 25 de outubro 2017.

[8] IBGE - Instituto Brasileiro de Geografia e Estatística. Aracaju Dados Gerais. 2017. Disponível em:<https://cidades.ibge.gov.br/painel/painel.php?lang=\&codmun=280030\&search=||infogr\%E1ficos:dados-gerais-do-munic\%EDpio> Acesso em: 24 de outubro 2017.

[9] IBGE - Instituto Brasileiro de Geografia e Estatística. Panorama. 2017. Disponível em: <https://cidades.ibge.gov.br/brasil/se/panorama> Acesso em: 25 de outubro 2017.

[10] IBGE - Instituto Brasileiro de Geografia e Estatística. População. 2017. Disponível em: $<$ https://seriesestatisticas.ibge.gov.br/series.aspx? $\mathrm{no}=10 \& \mathrm{op}=0 \& \mathrm{vcodigo}=\mathrm{CD} 90 \& \mathrm{t}=$ populacao-presenteresidente> Acesso em 25 de outubro 2017.

[11] MONTES, R.M; LEITE, J.F. A drenagem urbana de águas pluviais e seus impactos cenário atual da Bacia do Córrego Vaca - Brava Goiânia-GO, 2009.

[12] População estimada: IBGE, Diretoria de Pesquisas, Coordenação de População e Indicadores Sociais, Estimativas da população residente com data de referência 1 de julho de 2017

[13] TSUTIYA, M.; ALEM SOBRINHO, P. Coleta e Transporte de Esgoto Sanitário. Escola Politécnica da USP. São Paulo. 1999.

[14] TUCCI, C. E. M. ÁGUA NO MEIO URBANO, Universidade Federal do Rio Grande do Sul. Capítulo 14. 1997. Disponível

em:

$<$ http://www.pec.poli.br/sistema/material disciplina/fotos/\%C3\%A1guanomeio\%20urbano.pdf > Acesso em: 23 de outubro 2017.

[15] TUCCI, C. E. M. Gestão de águas pluviais urbanas. Ministério das Cidades, Brasília. 2006.

[16] TUCCI, C. E. M. Hidrologia: ciência e aplicação. Porto Alegre, Edusp / ABRH, 2002. 


\section{Capítulo 3}

\section{Manifestação patólogica de corrosão em estrutura metálica de quadras poliesportivas de escolas públicas estaduais da cidade de Aracaju}

\section{Anna Carla de Jesus Santos \\ Ana Angélica dos Santos Faro}

Resumo: A prática de esporte é uma ferramenta essencial para o desenvolvimento dos estudantes, pois potencializa suas competências técnicas, sociais e comunicativas. 0 ambiente da prática de esporte deve oferecer uma estrutura adequada para garantir segurança e proteção aos usuários. A deterioração dos ambientes públicos é um fator preocupante, a falta de conservação e controle das escolas, contribui para o surgimento de manifestações patológicas. Portanto, deve-se fazer um planejamento com cuidado e investir em uma estrutura de qualidade. 0 presente trabalho tem por objetivo fazer uma análise dos processos de corrosão em estrutura metálica de quadras poliesportivas em escolas públicas estaduais do município de Aracaju/SE. Para tal, este trabalho foi embasado em estudos de caso, onde foram feitas inspeções visuais e registros fotográficos da ocorrência da patologia citada, em 6 quadras poliesportivas escolhidas para investigação. Através da análise de resultados obtidos com a elaboração deste estudo, foram constatadas que as quadras poliesportivas apresentaram diversas formas de corrosão nas estruturas, resultando na interdição de uma delas devido à escassez da manutenção que influenciou no processo avançado de corrosão. Através dos fatos apresentados, é possível perceber a importância de uma manutenção adequada a estrutura metálica, e a negligência por parte dos responsáveis, que deixou chegar a estrutura nesse estado de abandono.

Palavras-chave: Deterioração metálica. Espaço público. Manutenção. 


\section{INTRODUÇÃO}

Os espaços públicos são importantes para os cidadãos, proporciona um local de encontro, um ambiente de acesso livre que contribui para o bem-estar e existência de novas experiências (DIXON, 2014). A quadra poliesportiva é um espaço importante da escola pública, pois é um ambiente que motiva os alunos à prática de esportes proporcionando a formação de habilidades físicas e uma vivência de respeito com o outro.

A construção em aço proporciona melhor aproveitamento dos espaços, apresenta obras enxutas, agilidade na execução com possibilidade de alcançar vãos nunca imaginado, além de revolucionar a modernização arquitetônica nas edificações, porém se faz necessário o cuidado na concepção estrutural para que no futuro não apresente manifestações patológicas.

A manifestação patológica que está presente na estrutura metálica é a corrosão, que na maioria das vezes aparece no processo espontâneo, quando exposto em ambiente inapropriado pode ocasionar alterações em matérias metálicas (LAUDONIO, 2013).

As construções em estrutura metálica deve apresentar um controle importante na realização da sua execução, planejamento e na sua manutenção no decorrer de sua vida útil.

Dessa maneira este trabalho tem o objetivo de analisar as manifestações patológicas de corrosão em estruturas metálicas de quadras poliesportivas de escolas públicas estaduais, localizadas na cidade de Aracaju/SE. A finalidade dessa inspeção nas quadras poliesportivas foi dar o suporte necessário para identificação e caracterização das patologias encontradas, a fim de propor uma solução, bem como verificar se existe um plano de manutenção por parte dos responsáveis por estes espaços.

\section{METODOLOGIA}

0 presente trabalho foi embasado em estudos de caso, onde tem características de metodologia qualitativa e exploratória, onde foram consideradas manifestações patológicas provenientes do processo de corrosão em estruturas metálicas, detectados em quadras poliesportivas em escolas públicas estaduais, localizado no município de Aracaju.

Conforme Gerhardt e Silveira (2009) a metodologia qualitativa tem o objetivo de aprofundar no estudo e não está preocupado em quantificar, e apresenta uma metodologia própria. Já a metodologia exploratória tem a finalidade de buscar semelhanças ao problema abordado, para melhor compreensão e análise, onde pode ser feita por pesquisa bibliográfica e estudo de caso.

\section{1 ÁREA DE ESTUDO}

O município de Aracaju ilustrado na Figura 1, foi fundado no dia 17 de março de 1885, com o propósito de ser a sede administrativa de Sergipe, pois havia a necessidade de ordem econômica para substituir São Cristóvão que era a antiga sede que ficava longe do mar. Essa mudança atendeu à pressão de senhores de engenho, que cobravam a construção de um porto para o escoamento da safra de açúcar (IBGE, 2018).

Aracaju está situada no estado de Sergipe, na região nordeste do país, na Latitude: 10 54 ' 40" S e Longitude: 37ํ 04' 18" W (GEOGRAFOS, 2018). A cidade de Aracaju é uma das primeiras capitais planejadas no Brasil, onde suas ruas foram distribuídas em condição geométrica, sendo comparada a um tabuleiro de xadrez, com o intuito de terminar no Rio Sergipe (NOGUEIRA, 2004). 
Figura 1: Área de estudo (a. Mapa do Brasil, b. Mapa de Sergipe, c. Mapa do município de Aracaju)

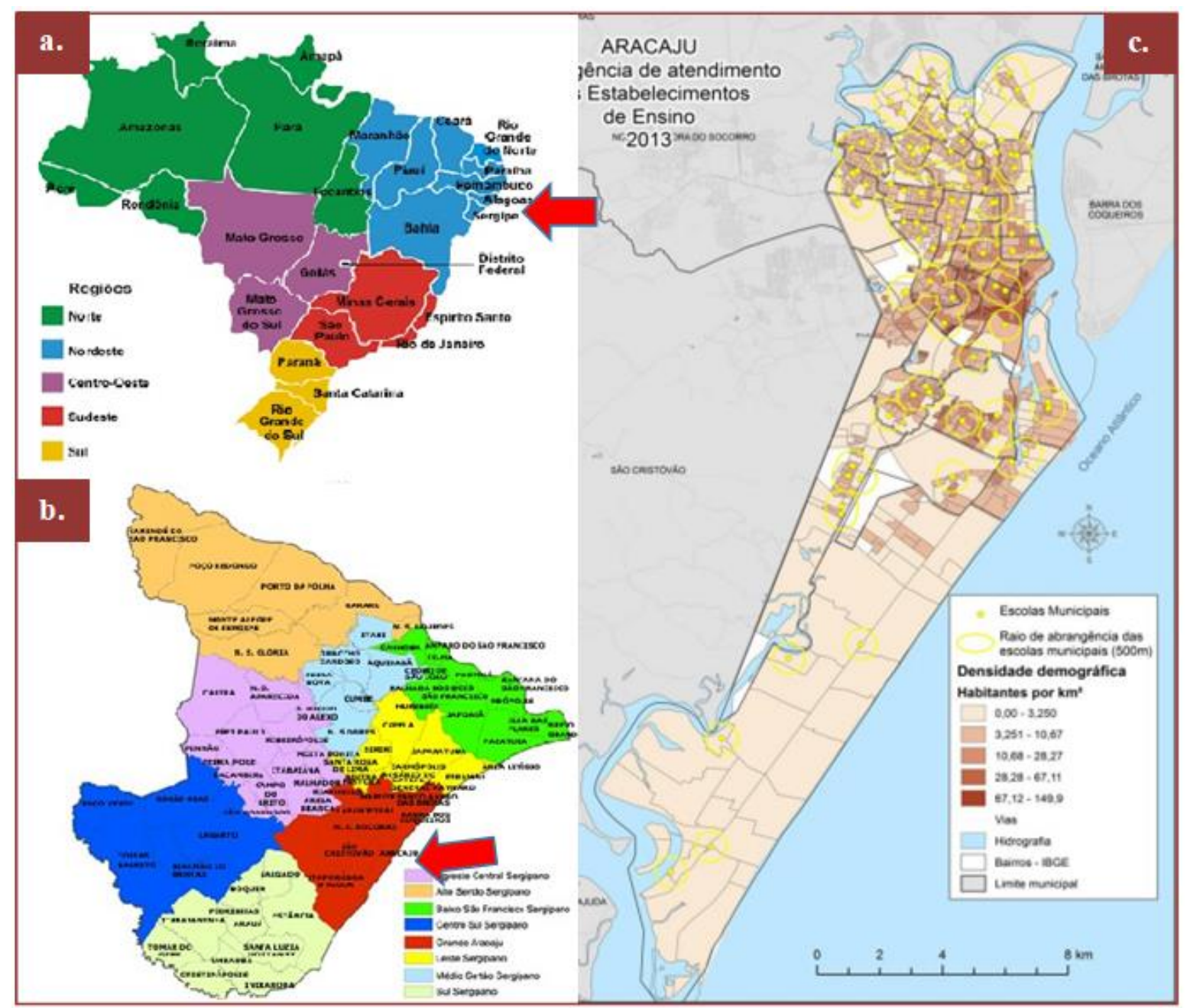

Fonte: (a) Noticia, 2018; (b) Imagens, 2007; (c) Plano, 2018

O estudo de caso foi realizado em seis escolas públicas estaduais, localizadas em bairros distintos do município de Aracaju tendo em vista que a prioridade para seleção da escola para estudo era de possuir quadra poliesportiva construída em estrutura metálica. No quadro 1 aparecem sumarizadas a nomenclatura associada a cada escola visitada e o bairro em que estão inseridas. Os locais escolhidos para serem estudados foram divididos em 6 casos, com o intuito de facilitar a identificação durante as análises. A Figura 2 apresenta o mapeamento das quadras poliesportivas escolhidas para estudo de caso.

Quadro 1: As quadras poliesportivas escolhidas para o estudo de Caso

\begin{tabular}{|c|c|}
\hline Escolas públicas & Bairros \\
\hline A & Getúlio Vargas \\
\hline B & Grageru \\
\hline C & Luzia \\
\hline D & Luzia \\
\hline E & São Conrado \\
\hline F & Farolândia \\
\hline
\end{tabular}

Fonte: Elaborado pela autora, 2018 
Figura 2: Mapeamento das escolas selecionadas

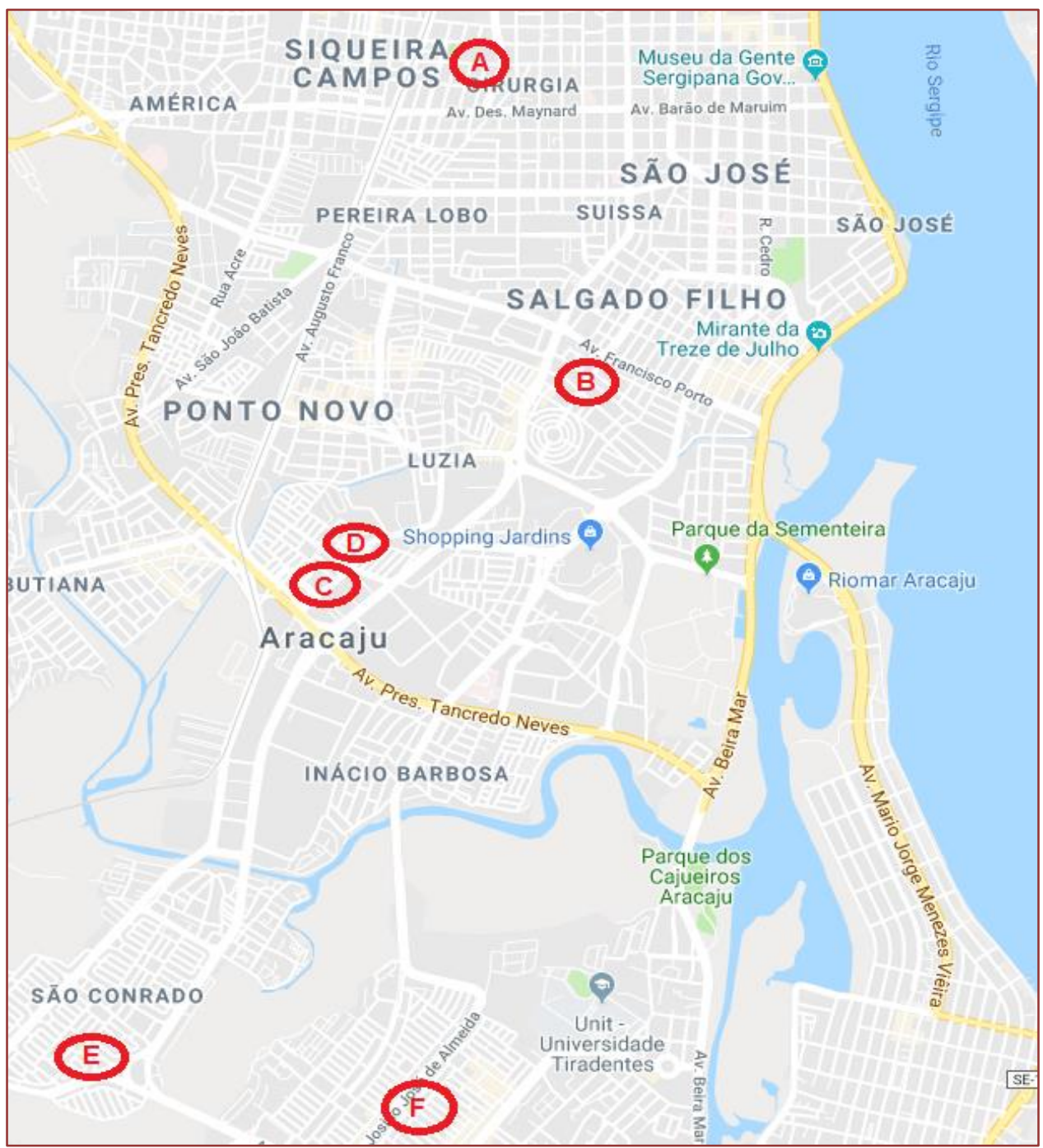

Fonte: Google Maps, 2018

\subsection{COLETA DE DADOS}

Os estudos foram baseados em livros e artigos científicos dispostos em plataformas de busca acadêmica como o Google Acadêmico, Scielo, entre outras, a respeitos de manifestações patológicas, corrosão em estruturas metálicas e metodologia.

Para a coleta de dados foi produzido um roteiro de inspeção para auxiliar na observação das patologias associadas à corrosão das estruturas metálicas das quadras poliesportivas conforme o Apêndice A. 0 estudo de caso foi fundamentado em análises visuais e fotográficas.

As vistorias foram realizadas nas quadras poliesportivas, no dia 13 de abril de 2018, das 8:30h às $17 \mathrm{~h}$. Foi realizada uma inspeção visual e fotográfica das manifestações patológicas encontradas em cada das quadras, e antes do início de cada inspeção, foi entregue ao coordenador da escola ou ao responsável um questionário, sobre a manutenção das quadras poliesportivas, contendo oito questões objetivas e subjetivas, que auxiliou na análise da evolução das patologias encontradas, bem como a frequência de reparo e manutenção da estrutura metálica.

Os registros fotográficos foram realizados de maneira cuidadosa e buscando melhor nitidez, foi utilizada uma câmera semiprofissional da marca Nikon, modelo Coolpix 1820, foram registradas imagens de processos corrosivos que apresentassem maior gravidade e variação de manifestação patológica.

0 acesso a todas as quadras visitadas foi autorizado pelo setor de engenharia da Secretaria de Estado de Educação (SEED). Para este órgão também foi elaborado um questionário, contendo cinco questões 
subjetivas sobre a existência de plano de manutenção e sua frequência. Ambos os questionários foram assinados pelos responsáveis deste órgão.

\subsection{ANÁLISE DOS DADOS}

A apresentação dos dados coletados será demonstrada através de quadros, gráficos, com a utilização do software Microsoft Word e Excel. Utilizando percentual e comparando com o referencial teórico, que foi levantado inicialmente através da pesquisa bibliográfica.

\section{RESULTADOS E DISCUSSÃO}

A prática de esportes é uma forma de proporcionar aos estudantes um bem-estar através de diferentes formas de atividades físicas, e contribuem para o rendimento nos estudos e desenvolvimento no raciocíno lógico e mental (LOPES, 2015).

Os ambientes selecionados para o estudo de caso foram divididos em 6 quadras poliesportivas (Figura 3), em estrutura metálica, localizado no município de Aracaju, com intuito de identificar as corrosões durante as análises mostradas a seguir.

Figura 3: (a. Quadra poliesportiva A, b. Quadra poliesportiva B, c. Quadra poliesportiva C, d. Quadra poliesportiva D, e. Quadra poliesportiva E, f. Quadra poliesportiva F)

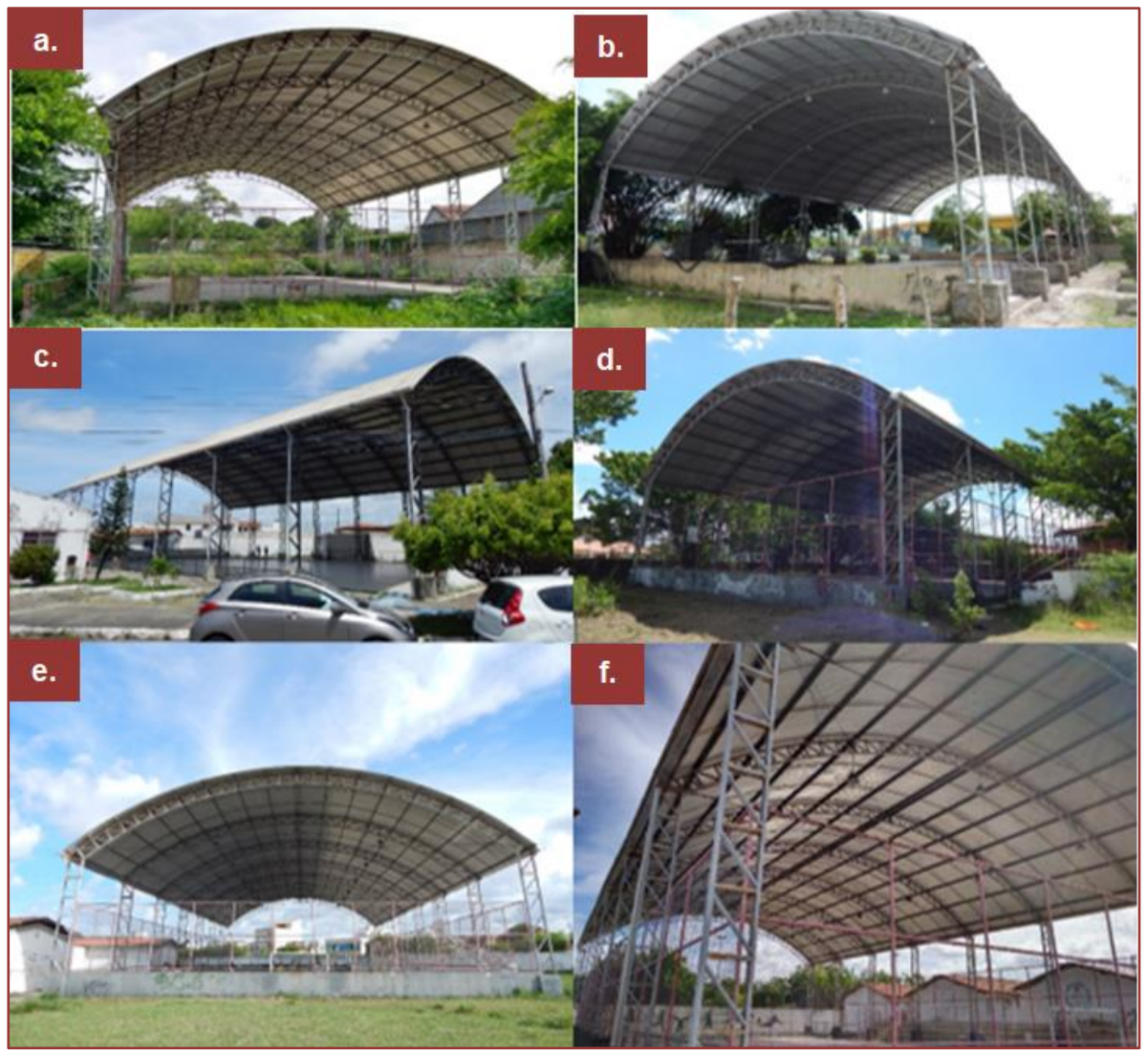

Fonte: Acervo pessoal, 2018 


\subsection{CASO 1 - QUADRA POLIESPORTIVA A}

A escola A foi fundada em 1972, é constituída do ensino fundamental regular, ensino médio regular e ensino médio inovador regular, com 505 matriculados em todos os turnos, localizada no bairro Getúlio Vargas, na zona centro de Aracaju.

A quadra poliesportiva A (Figura 3-a), está sem utilização do espaço desde 2011, por causa da corrosão avançada na sua estrutura metálica, por isso as atividades esportivas estão acontecendo em ambiente improvisado. A coordenação preocupada com a integridade dos alunos, impediu o acesso dos alunos à quadra, mas não foi visto no local, faixas de isolamento ou placas de risco. Porém, foi informado que em algumas semanas um vistoriador do Corpo de Bombeiros iria fazer uma visita ao local.

O responsável pela manutenção da escola informou que durante sua gestão, a quadra não recebeu manutenção e não existe um manual explicativo de manutenção na escola.

Na quadra poliesportiva A foi identificada a corrosão uniforme na superfície dos pilares metálicos e da viga arco metálica. Segundo Santos, Fioriti e Tsutsumoto (2011), este tipo de corrosão ocorre pelo fato da estrutura metálica estar em contato com ambiente atmosférico e por apresentar deficiência na proteção anticorrosiva da peça metálica. As corrosões apresentam diferentes tonalidades da sua oxidação na cor avermelhada no Pilar metálico e na viga metálica, já em outro Pilar metálico apresenta uma tonalidade marrom por não apresentar uma drenagem adequada e, consequentemente, acumulando poeira que pode ter acelerado o processo de corrosão.

Manifestações patológicas de corrosão por pites foram observadas em alguns pilares metálicos. Esses pilares apresentam uma oxidação da corrosão na tonalidade avermelhada que segundo Liubartas et al. (2014), ocorre por causa da exposição da estrutura metálica ao ambiente aquoso ou com presença de salinos.

Em outro pilar metálico, além de apresentar semelhança com outros pilares metálicos (oxidação com tonalidade avermelhada), tem uma característica diferente que foi observada, pois existe uma oxidação com tonalidade esbranquiçada. Segundo Neto e Vidrih (2011), a mancha branca é causada pela presença de um ambiente atmosférico que apresenta alta umidade e se manifesta quando se tem o processo de vaporização d'água, que após a solidificação conduz acúmulo de partículas de produtos químicos na superfície metálica gerando essa corrosão branca.

Na inspeção visual foi possível observar no pilar metálico, a corrosão por lixiviação que mostra uma oxidação avermelhada e acinzentada, e apresenta um estufamento em camadas, devido à corrosão. A corrosão por lixiviação apresenta uma carência na literatura que fundamente suas causas e consequências, e por este motivo não foi detalhada.

Outra manifestação que pode observa durante a inspeção visual foi a corrosão por ranhuras localizada nos pilares metálicos, também apresentou uma oxidação avermelhada nos cantos dos pilares. Segundo Centro (2010), essa corrosão pode ocorre pela exposição do perfil metálico sem proteção anticorrosiva e surgem nos cantos vivos da peça metálica.

No campo de estudo foi encontrada corrosão galvânica em elementos de ligação, localizada na calha de cobertura com viga arco metálico e na ligação de terça metálica com a calha de cobertura. Conforme esclarecido por Centro (2010), essa degradação ocorre particularmente quando existe o contato em telhas galvanizadas ou de alumínio com a peça metálica, na formação de furos nas peças estruturais e fixação das telhas com parafusos galvanizados, gerando o processo de corrosão.

$\mathrm{Na}$ inspeção visual foi encontrada em alguns pilares metálicos, uma corrosão que não foi possível identificar, pelo alto grau de corrosão que culminou na perfuração da camada do perfil metálico. De acordo com Santos, Fioriti e Tsutsumoto (2011), a corrosão em estado avançado pode ocorrer pela falta de drenagem das peças metálicas que não foi projetado, e com isso, gera o acúmulo de água no local, que contribui para o aceleramento da corrosão.

Segundo Brinck, Cândido e Neves (2008), a corrosão quando está avançada ocorre em ligação de perfis metálicos, em frestas, onde o material fica propício e se não for identificada no início, ocorre uma aceleração na corrosão e pode chegar ao estado de colapso. Como podemos observar, os alunos estão sujeitos ao perigo de desabamento da estrutura metálica da quadra A, e por esse motivo a coordenação da escola suspendeu as atividades físicas. 


\subsection{CASO 2 - QUADRA POLIESPORTIVA B}

A escola B foi fundada em 1987, está constituída por ensino fundamental regular, ensino médio regular e ensino médio inovador regular, apresenta 666 matriculados, localizada no bairro Grageru, na zona sul de Aracaju. Na realização da visita de inspeção foi observado que a escola se encontra em reforma, porém a quadra poliesportiva B (Figura 3-b), não vai passar por nenhuma manutenção.

A quadra poliesportiva B está sem utilização por causa da reforma da escola, mas existem atividades esportivas acontecendo normalmente no período letivo. Na visita foi verificado o processo de corrosão avançado, conforme ilustrado nas imagens a seguir. 0 responsável informou que na quadra B nunca foi realizada nenhuma manutenção e que não existe manual explicativo de manutenção.

Na quadra B foi encontrada corrosão do tipo uniforme na ligação do pilar metálico com a viga arco metálica, que esclarecido por Liubartas et al. (2014), essa degradação ocorre quando existe ausência de proteção anticorrosiva na superfície metálica que pode ocasionar a diminuição da massa uniforme do perfil. Pode-se observar na imagem que a instalação de uma lâmpada nessa ligação pode ser o fato do agravamento da corrosão.

Pode-se obeservar que os pilares metálicos apresentam corrosão por pites e outro pilar metálico além de apresentar as mesmas características, também apresenta algumas pichações na peça metálica feita por vândalos, que também podem ter contribuído para a corrosão.

Segundo Gentil (2011), na maioria das vezes podem ocorrer divergências na corrosão por pite com a corrosão alveolar e corrosão por placas, pois elas apresentam características semelhantes confundindo até mesmo os técnicos de inspeção. Para poder identificar melhor a corrosão por pite deve-se observar sua cavidade pelo número de pites por unidade de área, o seu diâmetro e sua profundidade.

Na inspeção visual foram encontrados em outros pilares metálicos, uma corrosão com forma arredondada na sua região e o tamanho vai aumentando em sua extremidade contaminando o perfil metálico.

Os pilares metálicos apresentam a corrosão alveolar, que apresenta uma forma circular, com tonalidade avermelhada-escura. Já outros pilares metálicos apresentam a corrosão alveolar, porém apresentam na extremidade da corrosão um formato diferente que está aumentando, e mostra desbotamento da pintura do perfil metálico.

Os pilares metálicos apresentam corrosão por lixiviação, devido à sua particularidade de apresentar camadas que formam estufamentos no perfil metálico, além de apresentar uma oxidação avermelhada. Segundo Fogaça (2018), essa oxidação avermelhada ocorre quando está na presença de alguma solução aquosa de sulfato, que ao decorrer do tempo vai surgindo na lâmina da peça metálica uma corrosão avermelhada.

Na inspeção visual foi encontrada a corrosão galvânica na ligação do pilar metálico com a calha metálica, no suporte metálico de fixação com a calha metálica, no cabo preso no gancho da viga arco metálica, nos parafusos de fixação da viga arco metálica e nos parafusos no pilar metálico. Segundo esclarecido por Liubartas et al. (2014), essa corrosão manifesta-se através de contato com a fixação de furos e parafusos galvanizados em perfil metálico e também pode apresentar-se em elementos metálicos em contato com telhas galvanizadas ou de alumínio.

Além da corrosão galvânica presente no pilar metálico com a calha metálica é possível observar que a calha está com uma infiltração de água da chuva, que foi um dos fatores que acelerou o processo de corrosão. Segundo Araújo (2015), a corrosão pode manifestar na estagnação de água em uma fresta do perfil metálico e na velocidade em que ocorre o escoamento da água.

Na inspeção visual foram encontradas nos pilares metálicos corrosão em um estado avançado. Segundo Santos e Cabral (2011) indagam que a corrosão chega em um nível avançado quando existe o surgimento de intempéries do meio corrosivo devido ao acréscimo de água que contribui para o aumento da velocidade da corrosão. A corrosão avançada traz perigo, pois pode indicar que a estrutura está entrando em colapso e ainda coloca em risco a vida de quem faz uso da quadra. 


\subsection{CASO 3 - QUADRA POLIESPORTIVA C}

A escola C foi fundada em 1977, e está constituída por ensino fundamental regular e ensino fundamental para educação de jovens e adultos, apresenta 241 matriculados, fica localizada no bairro Luzia, na zona sul de Aracaju.

A quadra poliesportiva C (Figura 3-c) está realizando todas as atividades esportivas normalmente. Na estrutura metálica foi realizada uma manutenção corretiva em 2017, porém, a estrutura já apresenta corrosão. 0 responsável pela manutenção foi o setor de engenharia de SEED e foi constatado que não existe um manual explicativo de manutenção.

Nos pilares metálicos, foram encontradas corrosões alveolares que apresentam formatos arredondados e crateras na região da peça metálica, que é bem semelhante à corrosão alveolar detectada na Quadra B.

A corrosão galvânica foi encontrada na fixação da telha metálica na terça metálica, como mencionado anteriormente, Liubartas et al. (2014) explica que esse ataque ocorre em contato com a fixação de furos e parafusos galvanizados em perfil metálico.

Nos pilares metálicos foram encontradas uma manifestação na ligação de solda da chapa nos pilares, e de acordo com Bó e Sartoni (2012), essa corrosão ocorre em ligações de soda pela a falta de proteção de pintura e também por estar em um ambiente agressivo.

No banzo inferior da viga arco metálico foi encontrada a corrosão por lixiviação, onde apresentar o descascamento na pintura e lâminas de oxidação avermelhada no perfil metálico.

Outra manifestação observada durante a inspeção visual foi a corrosão por pites no pilar metálico, que apresenta pontos pequenos na região da peça metálica, e que ocorre em ambientes expostos às intempéries da atmosfera como chuvas, ventos e etc. Segundo Liubartas et al. (2014), essa corrosão por pites geralmente ocorre em ambientes úmidos ou drenagem deficiente, podendo ocorrer pequenos furos que surgem da infiltração no perfil metálico e provoca uma acomodação de água ocasionando a corrosão.

Na quadra C também foi identificada corrosão uniforme nos pilares metálicos, com um grau alto de corrosão e uma tonalidade de oxidação marrom-avermelhada, que segundo Abreu et al. (2017), ocorre devido à falta de revestimento de proteção adequado para o perfil metálico.

\subsection{CASO 4 - QUADRA POLIESPORTIVA D}

A escola D foi fundada em 1975, é constituída por ensino fundamental regular e ensino médio inovador regular, apresenta 839 matriculados, e fica localizada no bairro Luzia, na zona sul de Aracaju.

A quadra poliesportiva D (Figura 3-d), está em plena utilização, sua estrutura metálica apresenta um alto grau de corrosão. Foi informado pelo gestor que desde o início de sua gestão a quadra nunca passou por uma manutenção, que não existe manual explicativo de manutenção e o responsável pela estrutura é o setor de engenharia de SEED.

Na quadra D foi identificada a corrosão uniforme nos pilares metálicos, onde é possível observar uma grande área do perfil metálico acometido por este tipo de manifestação. Segundo citado anteriormente por Abreu et al. (2017), essa corrosão ocorre pela escassez de um revestimento anticorrosivo na peça metálica.

O pilar metálico apresenta uma corrosão do tipo alveolar, semelhante aos casos anteriores, que tem formatos circulares, porém com uma tonalidade diferente, mais escura. Na lateral desse pilar metálico também foi observado descascamento da pintura de proteção.

A corrosão galvânica se fez presente na ligação da terça metálica com a calha localizado no pilar metálico e na emenda de perfis metálicos no pilar metálico, provavelmente devido a aplicação inadequada de solda ao perfil. Conforme explicado por Araújo (2015), essa corrosão se manifesta quando existem metais diferentes, onde um dos metais apresenta negatividade inferior ocasionando a corrosão.

A corrosão por lixiviação foi observada nos pilares metálicos, onde existe camadas de oxidação avermelhadas e inchamento do perfil metálico.

Na chapa de base do pilar metálico, foi identificada corrosão por placas, que ocorre quando o material está exposto a condições climáticas, chuva e poeira. Segundo esclarecido por Neto e Vidrih (2011), essa corrosão ocorre em contato com área úmidas, quando o perfil é infiltrado pela água, geralmente através de 
uma má execução ou sem um escoamento adequado que fazem surgir a deficiência na superfície da chapa e acelera o processo de corrosão.

Outra manifestação patológica encontrada na quadra D, foram arranhões no pilar metálico, provenientes de vandalismo que podem ter influenciado no aparecimento da manifestação de corrosão. Nos pilares metálicos foram observadas a corrosão em estado avançado que impossibilitou a determinação do tipo de corrosão que iniciou o processo. São características notórias na peça, oxidação avermelhada, crateras, e o inchamento da camada da peça metálica. A corrosão avançada de peças metálicas estruturais deixam o ambiente propício a ocorrer acidentes com os alunos, além da possibilidade de ocorrer um desabamento.

\subsection{CASO 5 - QUADRA POLIESPORTIVA E}

A escola E foi fundada em 1987, está constituída por ensino fundamental regular, ensino médio regular e ensino médio inovador regular, apresenta 858 matriculados, e fica localizada no bairro São Conrado, na zona sul de Aracaju.

Na quadra poliesportiva E (Figura 3-e) está acontecendo todas as atividades físicas e a sua estrutura apresenta mediamente corrosão, porém, não souberam informar quando ocorreu a última manutenção e não apresentaram nenhum manual explicativo de manutenção, e informaram que a responsabilidade por toda manutenção na quadra é do setor da SEED.

Na visita foi detectada a corrosão galvânica na ligação do suporte para calha ligada à viga arco metálica, na ligação do Cabo metálico com um gancho fixado no banzo inferior da Viga arco metálica, e na viga metálica com a terça e com a calha. Este tipo de corrosão ocorre devido ao contato entre metais diferentes. Apresentam uma tonalidade avermelhada, descascamento da pintura, que devido a exposição à chuvas e ventos tiveram o processo de instauração da manifestação acelerado.

A corrosão por frestas foi observada em uma abertura entre as peças metálicas, no banzo inferior localizado na viga arco metálico e na junção de dois perfis metálicos no pilar metálico, que através da falta de solda, e o contato com o ambiente externo manifestou a corrosão.

Na inspeção foi detectada uma corrosão uniforme que se manifestou em grande área do perfil do pilar metálico e a viga arco metálico, proveniente da exposição ao ambiente externo e da falta de proteção anticorrosiva que culminou na aceleração do processo de corrosão.

\subsection{CASO 6 - QUADRA POLIESPORTIVA F}

A escola F foi fundada em 1982, é constituída por ensino fundamental regular e ensino médio regular, apresenta 753 matriculados, fica localizada no bairro Farolândia, na zona sul de Aracaju,

A quadra poliesportiva F (Figura 3-f), está sendo utilizada para a prática das atividades esportivas escolares, porém não só os alunos estão utilizando, foi informado que a comunidade utiliza o espaço quando não está ocupada. Comunicaram também que existe manutenção a cada 6 meses na escola, porém não souberam informar sobre a manutenção da quadra, pois é de responsabilidade do setor de engenharia da SEED.

Na inspeção a quadra F, foram detectadas nos pilares metálicos, a corrosão alveolar com um formato arredondado e oxidação marrom-avermelhada. Já em outro pilar metálico foi observada corrosão alveolar com tonalidade de oxidação marrom-avermelhada, porém com dimensões maiores que nos pilares anteriores.

Outra manifestação foi detectada na chapa de ligação do apoio da viga arco metálica, corrosão por lixiviação, que está localizada próximo aos parafusos e na extremidade da chapa. Esta manifestação ocorre através do inchamento devido ao acúmulo de água da chuva, que forma camadas de oxidação marromavermelhada.

A corrosão identificada na superfície do pilar metálico, apresenta a corrosão uniforme, presente em uma determinada área, exposta ao ambiente provido de corrosão atmosférica e devido a uma falta de proteção anticorrosiva.

Outra manifestação patológica de corrosão que não foi possível identificar está localizada no centro da viga arco metálica. Esta corrosão está em estado avançado e se alastra por grande parte da superfície metálica. 


\subsection{ANÁLISE DAS CORROSÕES MAIS FREQUENTES DAS QUADRAS POLIESPORTIVAS SELECIONADAS}

Após análise de todas informações apresentadas acima, é possível observa como se encontra o ambiente onde ocorre a prática de esporte dos alunos, devido ao estado da estrutura metálica das quadras poliesportivas das escolas públicas estaduais do município de Aracaju.

Como foi observado, em todas as quadras foram detectadas manifestações de corrosão de vários tipos e em diferentes estágios, sendo que a quadra A está interditada desde 2011 e se apresenta em estado de total abandono, com bastante vegetação tomando todo o local, e corrosão avançada apresentando peças metálicas em colapso.

Para que a estrutura metálica não chegue ao estado de degradação deve-se conscientizar sobre a importância da estrutura necessita ser preservada e que exista um controle para evitar a corrosão (LAUDONIO, 2013).

Todas as quadras estão em desacordo com o projeto padrão do Fundo Nacional de Desenvolvimento da Educação (FNDE) definido em 2011, isto porque quando as quadras foram construídas ainda não existia este projeto básico. Foram verificadas nas quadras analisadas as inconformidades do projeto básico do FNDE $^{1}$, que foram a ausência da pintura especificada, modelo estrutural diferente da calha, falta da base de concreto no pé do pilar metálico, e no caso da existência da base não apresentava a altura especificada e fechamento da cobertura, nem telha translúcida ondulada na cobertura e apresentava dimensões maiores. Fatores como tempo da estrutura com mais de 30 anos e a falta de manutenção, podem ser as causas prováveis para o surgimento dessa diversidade de manifestações de corrosão que deixam os espaços públicos escolares e comunitários em estado avançado de deterioração colocando em risco seus usuários.

Para se ter uma visão geral dos tipos de corrosão observados o gráfico abaixo mostra por quadra analisada os tipos de corrosão mais frequentes nas estruturas metálicas (Figura 4).

Figura 4: Gráfico representativo dos tipos de corrosão mais frequentes nas estruturas metálicas das quadras analisadas

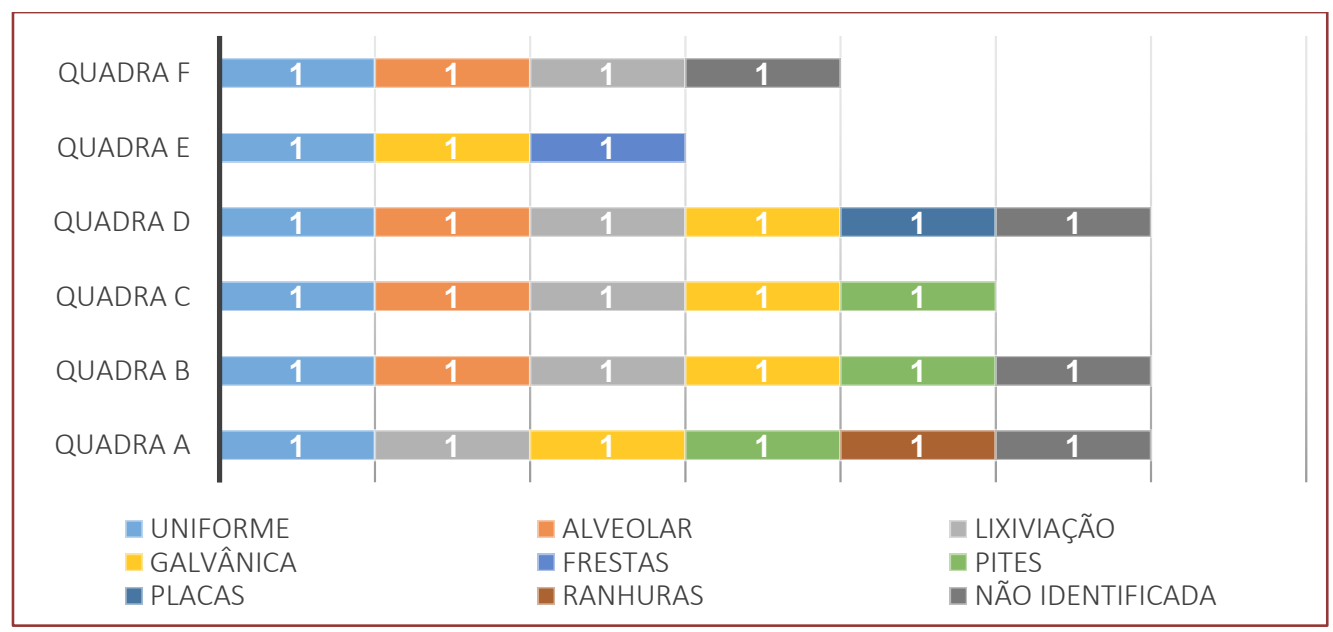

Fonte: Elabora pela autora, 2018

É possível analisar através dos resultados do Gráfico (Figura 3), que todas as quadras poliesportivas selecionadas apresentaram corrosão em sua estrutura metálica, ou seja, a corrosão se faz ainda presente na construção metálica.

Com essa fundamentação pode-se identificar a gravidade do risco que os alunos de rede pública estão enfrentando na escola. As corrosões no geral foram decorrentes de mal concepção de projeto, material com proteção inadequada e a escassez de uma manutenção. Segundo Bó e Sartorti (2012), as obras de estrutura metálica necessitam de uma excelente percepção na elaboração das fases de projetos, uma

1 Projeto básico do FNDE. 2015. Disponível em < http://www.fnde.gov.br/programas/par/eixos-deatuacao/infraestrutura-fisica-escolar/item/5960-cobertura-de-quadra-escolar-pequena $>$. Acessado em 05, maio, 2018. 
logística na fabricação, montagem e manutenção eficaz, para que futuramente não manifestem defeitos na sua utilização. Na maioria das construções, a ausência de execução de qualidade e de materiais inadequados ao ambiente certo, conduz para o surgimento de corrosão.

As anomalias em estruturas metálicas estão propícias às falhas de projetos, erros na fabricação e montagem, por causa de negligência ou inexistência de controle de qualidade ou então da falta de manutenção (SACCHI; SOUZA, 2016).

0 quadro 2 mostra os tipos de corrosão encontrados nas seis quadras poliesportivas das escolas públicas estaduais analisadas e suas prováveis soluções.

Quadro 2: Possíveis soluç̧̃es para as corrosões coletadas

\begin{tabular}{|l|l|}
\multicolumn{1}{c}{$\begin{array}{c}\text { Tipo de } \\
\text { corrosão }\end{array}$} & \multicolumn{1}{c|}{ Solução } \\
\hline $\begin{array}{l}\text { Alveolar, } \\
\text { Placas e Pites }\end{array}$ & $\begin{array}{l}\text { Na peça metálica deve-se efetuar a limpeza no local e se a estrutura não estiver } \\
\text { comprometida, pode-se cobrir o furo aplicando um selante especial. }\end{array}$ \\
\hline Frestas & $\begin{array}{l}\text { Se a corrosão estiver em estágio inicial, pode-se recorrer à limpeza superficial, } \\
\text { secagem do interior da fenda e vedação com um líquido selante e depois aplicar um } \\
\text { revestimento protetor. }\end{array}$ \\
\hline Galvânica & $\begin{array}{l}\text { Uma forma muito utilizada é a proteção catódica, que faz que a peça metálica se } \\
\text { comporte como cátodos de uma pilha eletrolítica com o uso de metais de sacrifício. } \\
\text { Dessa forma, a estrutura funcionará como agente oxidante e receberá corrente } \\
\text { elétrica do meio, não perdendo elétrons para outros metais. }\end{array}$ \\
\hline Lixiviação & $\begin{array}{l}\text { A peça metálica passa por um tratamento térmico, onde a peça metálica passa por } \\
\text { aquecimento e depois resfriamento, que proporciona atingir as propriedades } \\
\text { mecânica desejada do metal. }\end{array}$ \\
\hline Avançada & $\begin{array}{l}\text { Necessita de uma limpeza na peça metálica danificada, removendo-se todas as } \\
\text { impurezas, caso a peça esteja muito degradante, deve ser pintada para a interrupção } \\
\text { da corrosão. }\end{array}$ \\
\hline Uniforme & $\begin{array}{l}\text { Precisa fazer uma limpeza superficial com jato de areia no elemento metálico } \\
\text { deteriorado e depois substituir a pintura antiga por uma pintura anticorrosiva. Caso } \\
\text { o perfil encontre com alto corrosividade deve remove o elemento deteriorado por } \\
\text { um novo de acordo com sua especificação do projeto. }\end{array}$ \\
\hline
\end{tabular}

Fonte: CENTRO, 2010; GENTIL, 2011.

As recomendações adequadas para as quadras poliesportivas, em estrutura metálica devem elaborar o projeto básico da FNDE, que possui um controle de proteção anticorrosiva, uma drenagem adequada e um planejamento das manutenções preventivas. Segundo Costa (2012), é fundamental identificar os métodos preventivos para assegurar a durabilidade e desempenho das estruturas.

As estruturas metálicas necessitam de medidas de proteção para evitar essa manifestação patológica, e de acordo com Nunes (2003), existem medidas de prevenção que podem evitar a corrosão, por exemplo:

- Proteção Catódica: aplicação de corrente externa;

- Passivação: alguns perfis metálicos sofrem oxidação dando surgimento a finas películas de óxidos estáveis, com combate posterior à corrosão;

- Revestimentos metálicos;

- Revestimentos orgânicos: pinturas, óleos, substâncias betuminosas, entre outras;

- Revestimentos inorgânicos;

- Evitar contatos bimetálicos;

- Remoção de oxigênio e água. 
As estruturas metálicas necessitam da existência de um plano de manutenção para que seja um suporte para o profissional responsável e ele possa avaliar a edificação e assegurar a segurança adequada. A manutenção deve ser feita no tempo programado e por um profissional experiente que utilize dos ensaios não destrutivos como uma ferramenta de grande importância, sendo possível avaliar a integridade e o atual estado de uso das edificações em estruturas metálicas (COSTA, 2012).

Durante as inspeções foram realizadas entrevistas, com questionários, entregues aos responsáveis pelas 6 quadras, com intuito de coletar informações de como está sendo gerida a manutenção nas quadras poliesportivas nas escolas públicas estaduais em Aracaju, se existe manual de manutenção explicativo e planejamento para essa manutenção. No gráfico abaixo, podemos observar quantas escolas atendem a esses requisitos. (Figura 5)

Figura 5: Gráfico representativo das quadras poliesportivas selecionadas se existe manutenção, manual explicativo e planejamento.

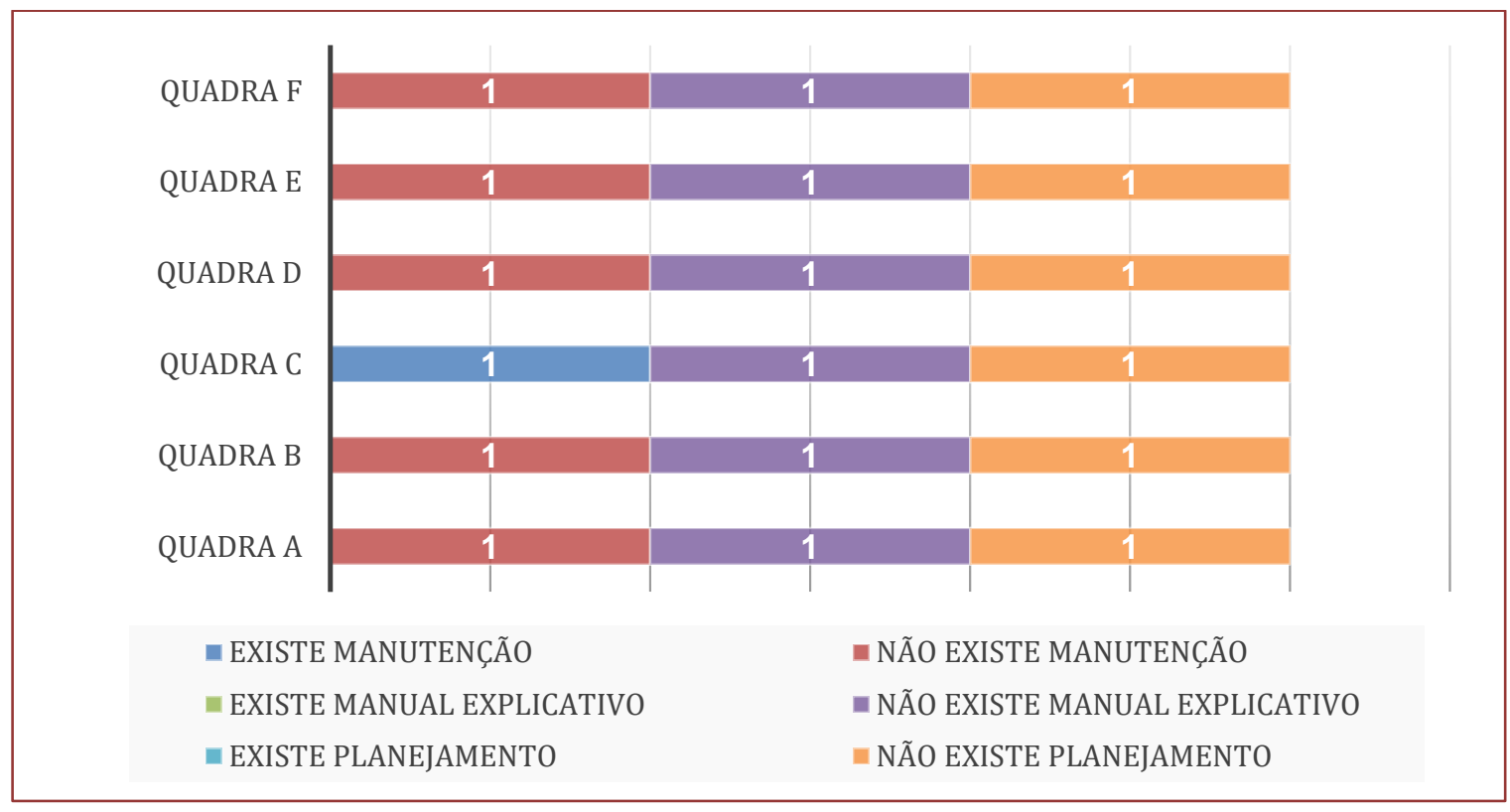

Fonte: Elaborada pela autora, 2018

Como podemos observar no gráfico representativo (Figura 5), das seis quadras somente uma recebe manutenção e nenhuma delas possui manual de manutenção explicativo e um planejamento dos serviços.

Outras informações foram coletadas do questionário, através de perguntas sobre o tipo de manutenção que é feita nas quadras poliesportivas das escolas públicas estaduais e são apresentadas no gráfico. (Figura 6).

Pode-se observar para as respostas dadas que em 50\% das quadras poliesportivas não existem nenhum tipo de manutenção, que 33\% apresentam manutenção corretiva e somente $17 \%$, no caso, uma quadra realiza a preventiva. Conforme Rosa e Pravia (2011), a manutenção não é somente uma resolução de problemas possíveis, tem que ser uma forma objetiva de atividades com desempenho das edificações e um suporte aos usuários para que atendam à sua vida útil projetada. 
Figura 6: Gráfico representativo das manutenções frequentes nas quadras poliesportivas selecionadas.

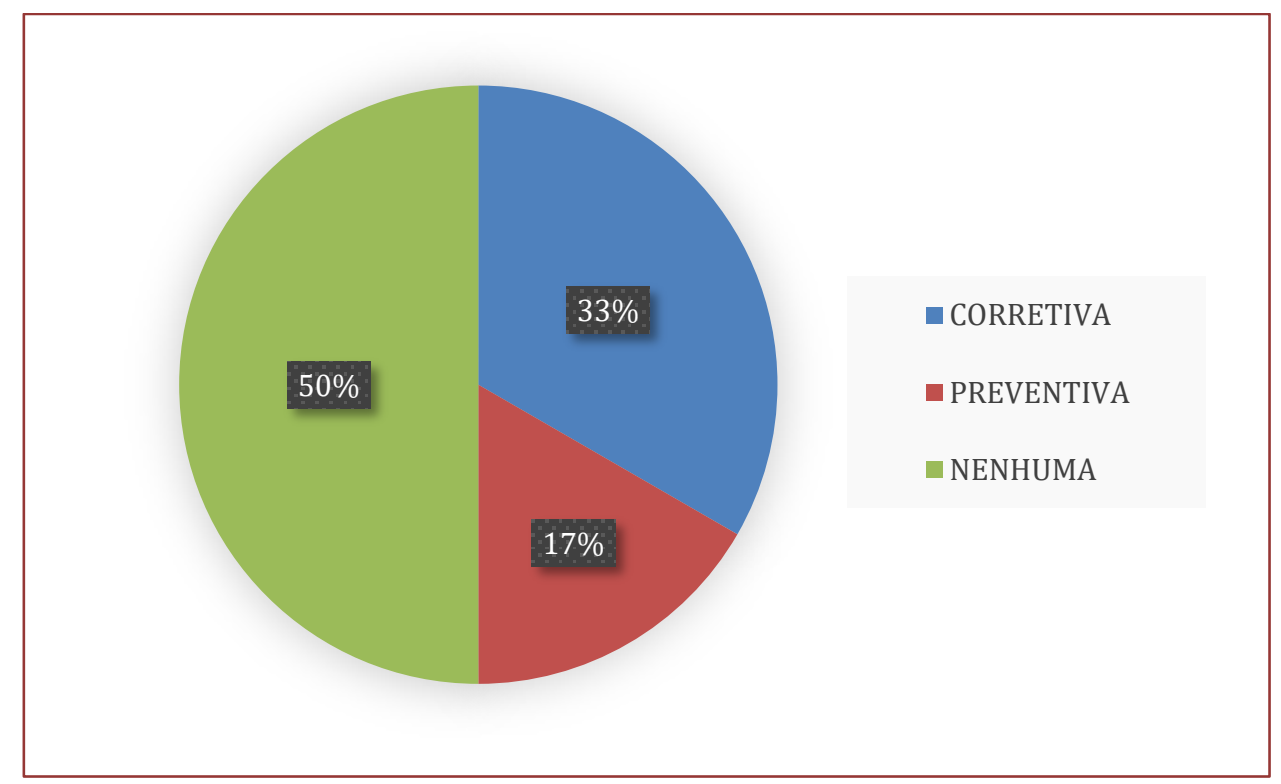

Fonte: Elabora pela autora, 2018

\subsection{RESPONSÁVEIS PELA MANUTENÇÃO DAS QUADRAS POLIESPORTTIVAS}

A manutenção das escolas públicas estaduais é de responsabilidade da Secretaria do Estado da Educação de Sergipe (SEED), onde existe um setor de engenharia responsável por essas quadras poliesportivas.

Em uma visita ao setor de engenharia foi feita uma entrevista com o engenheiro civil Felipe, responsável pelas quadras, que informou que o setor tem a finalidade de fazer o planejamento e fiscalizar os serviços realizados pelas empresas terceirizadas, e que esse serviço das quadras poliesportivas só pode ser realizado através da solicitação do diretor da escola para o setor, e logo após, o pedido é encaminhado ao setor de licitação. 0 único serviço de manutenção realizado pelo setor é o de pintura, sendo solicitada pelo diretor da escola, que também é encaminhada ao setor de licitação. Todas as licitações são feitas pela Companhia Estadual de Habitação e Obras Públicas (CEHOP).

No setor de engenharia não existe um arquivo do histórico de reforma para averiguarmos o que aconteceu com a quadra, desde sua criação. Ele também informou que não existe manual explicativo para as quadras poliesportivas e que no futuro as mesmas terão suas estruturas metálicas substituídas por estruturas de concreto, que exigem menor número de manutenções.

\section{CONCLUSÃO OU CONSIDERAÇÕES FINAIS}

Conclui-se que as quadras poliesportivas selecionadas possuem diferentes formas de corrosão, e apresentam um estado de degradação avançada. De acordo com os responsáveis pelas quadras não possuem a existência de um plano de manutenção periódico e contribuindo, assim, para o surgimento dessas manifestações patológicas.

As corrosões encontradas nas quadras foram devidamente identificadas e algumas caracterizadas, porém, algumas corrosões não têm a existência de muita fundamentação na literatura. Diante das corrosões apresentadas, foram elaboradas possíveis soluções de recuperação para a sua estrutura, com intuito de proporcionar um suporte de estudo.

A manutenção das quadras poliesportivas encontram-se em um estado de abandono, existe uma negligência por parte dos responsáveis que deixaram a estrutura chegar no estado de colapso, colocando em risco os usuários das quadras.

Diante dos fatos apresentados, é possível perceber a importância de uma manutenção adequada que proporcione uma vida útil programada para a estrutura metálica. 0 setor responsável pelas quadras poliesportivas devem se conscientizar e elaborar um plano de manutenção e colocá-lo em prática 
contratando pessoas qualificadas que garantam um serviço de qualidade. Com isso, proporcionando um ambiente seguro para prática de esporte dos alunos.

\section{REFERÊNCIAS}

[1] ABREU R.V.S de et al. "O estudo do processo de corrosão de estruturas metálicas expostas às intempéries ambientais em Manhuaçu-MG". Revista educação, meio ambiente e saúde. 2017.

[2] ARAÚJO. Adriana "Metais na construção civil: corrosão e proteção", Sindicato da construão civil são Paulo, Instituito de pesquisa tecnológica, 2015, disponível < https://pt.slideshare.net/AdrianadeAraujo/metais-na-construo-civil-corroso-e-proteo $>, \quad$ acessado $06 / 06 / 2018$, as $20: 41 \mathrm{~h}$

[3] BO. Tânia Cristina Machado Dal', SARTORTI Artur Lenz. Artigo Técnico "Falhas e Patologias nas Estruturas Metálicas", 2012.

[4] BRINCK.Fabiana Malta, CÂNDIDO.Luiz Cláudio e NEVES.Francisco de Assis das. Artigo técnico, "Estudo do fenômeno de corrosão na ponte marechal hermes no rio são Francisco". 2008

[5] CENTRO (Centro de Estudos de Engenharia Civil da Universidade Federal do Paraná), Artigo técnico, "Corrosão em estruturas metálicas", 2010.2 Acessado http://www.metalica.com.br/pg dinamica/bin/pg dinamica.php?id pag=1341. Acessado em 25, março, 2018.

[6] COSTA. Fabio Gomes da. Artigo técnico "Manutenção das estruturas metalicas com utilização dos ensaios não destrutivos. 2012.

[7] DIXON. Caitlin. "A Importância dos Espaços Públicos: Uma Introdução", 2014. Disponivel em < http://rioonwatch.org.br/?p=10766 >, Acessado em 19, junho, 2018.

[8] FOGAÇA. Jennifer Rocha Vargas. Disponível em < https://alunosonline.uol.com.br/quimica/reacoes-oxirreducao.html >, Acessado em 19, junho, 2018.

[9] GEOGRAFOS, Disponivel em: <http://www.geografos.com.br/cidades-sergipe/aracaju.php>, Acessado em 06, maio, 2018.

[10] GENTIL, Vicente. Corrosão. 6⿳a ed. Rio de Janeiro: LTC Editora, 2011.

[11] GERHARDT. Tatiana Engel e SILVEIRA. Denise Tolfo, 2009) "Metodos de pesquisa ", 2009, Disponivel em http://www.ufrgs.br/cursopgdr/downloadsSerie/derad005.pdf $>$, acessado 04/03/2018, as $8: 45 \mathrm{~h}$.

[12] IBGE, Disponivel em:<https://cidades.ibge.gov.br/brasil/se/aracaju/historico $>$, Acessado em 12, maio, 2018.

[13] IMAGENS, 2007; Disponivel em < http://imagensparacelularblog.blogspot.com/2013/01/mapade-sergipe-e-suas-cidades-colorir.html $>$, Acessado em 05, maio,2018.

[14] LAUDONIO. Fábio. "Corrosão em estruturas metálicas, métodos como a galvanização podem ajudar a combater o problema." Revista Infraestrutura, 2013. Disponivel em < http://www.icz.org.br/upfiles/fckeditor/file/923-

Revista Engenharia Civil Corrosao de Estruturas Junho de 2013.pdf> , Acessado em 08, junho, 2018.

[15] LIUBARTAS, D. et al.,“A sustentabilidade do aço e das estruturas metálicas”, 2014.

[16] LOPES. Valquiria. "Esporte ajuda a melhorar notas e convívio social", 2015. Disponível em < https://www.em.com.br/app/noticia/especiais/educacao/2015/05/14/internas educacao,647407/espo rte-para-melhorar-notas-e-convivio-social.shtml >, Acessado em 09/06/2018, as 16:02h.

[17] NETO Pedro, VIDRIH. Claudio. Artigo técnico " Patologia em construções mistas concreto e aço (estudo de caso). 2011.

[18] NOGUEIRA. Adriana dantas, Tese de Doutorado "Análise sintático-espacial das transformações urbanas de aracaju (1855 - 2003)", 2004.

[19] NOTICIA, 2018; Disponivel em < https://noticiasconcursos.com.br/processo-seletivo-daprefeitura-de-santo-antonio-da-patrulha-rs-2018/mapa-do-brasil-regioes/ >, Acessado em 05, maio,2018. 
[20] NUNES. Valentim M B. “ Electroquímica e corrosão, 2003. Disponível em < http://www.docentes.ipt.pt/valentim/ensino/corrosao.pdf $>$, Acessado em 20, maio, 2018.

[21] PLANO, 2018; Disponivel em < http://aracaju.se.gov.br/userfiles/plano-diretor-vpreliminiarjul2015/CAPITULO-II-ASPECTOS-SOCIO-ECONOMICOS.pdf $>$, Acessado em 14, junho,2018.

[22] ROSA. Guillermo Rovatti e PRAVIA. Zacarias M. Chamberlain, Artigo técnico "Planos de manutenção para empreendimentos em estruturas de aço", na revista Construção Metálica Edição 103, 2011, disponível < https://issuu.com/prodweb/docs/rcm-ed-103> , acessado 07/05/2018, as 10:40h.

[23] SACCHI. Caio César, SOUZA. Alex Sander, artigo técnico "Manifestações patológicas e controle de qualidade na montagem e fabricação de estruturas metálicas”, publicado em 30 de agosto de 2016.

[24] SANTOS. Thais da Silva, FIORITI. Cesar Fabiano, TSUTSUMOTO. Nayra Yumi (2011), artigo técnico, "Avaliação de manifestações patológicas em edificações com estruturas de aço",

[25] SANTOS. Davi Valente e CABRAL. Antônio Eduardo Bezerra. Artigo técnico "Diagnósticos de patologias em estruturas metálicas do theatro josé de alencar", 7̣a Congresso internacional sobre patologia e reabilitação de estruturas. 2011. 


\section{Capítulo 4}

\section{Substituição dos agregados naturais por agregados reciclados em concreto estrutural}

\section{Rafaella Lima Correia \\ Giseli Barbosa de Lima}

Resumo: A realização de uma eficaz gestão e gerenciamento dos resíduos da construção é um desafio ao meio técnico-acadêmico e a administração das grandes cidades. A reciclagem dos Resíduos da Construção e Demolição - RCD tem se tornado uma solução para o gerenciamento dos mesmos, em função do elevado volume de agregados que são utilizados pela construção civil. 0 trabalho tem como objetivo avaliar a possibilidade de substituir de forma total ou parcial o agregado natural por agregado reciclado oriundo de resíduos da construção e demolição no concreto estrutural. Devido ao alto consumo de recursos naturais, a reciclagem de RCD tornar-se uma prática importante minimizando o impacto ambiental causado pelo setor da construção civil. Em diversos estudos publicados quanto à utilização de RCD em concreto estrutural não há uma unanimidade com relação ao seu desempenho. Os principais motivos é a variabilidade presente na composição destes agregados. Controlando esta variabilidade torna-se mais viável garantir que os concretos produzidos com este tipo de agregado obtenham desempenho e durabilidade. As pesquisas deste trabalho foram realizadas no município de Aracaju, Nossa Senhora do Socorro e Barra dos Coqueiros, através de visitas a órgãos ambientais, pesquisas de campo em construtoras e concreteiras, por sua vez os resultados obtidos mostram a falta de conhecimento sobre agregado reciclado, a produção deste no estado e aceitação em utilizar o agregado reciclado, mesmo não existindo normatização brasileira sobre o assunto.

Palavras-chave: Estrutura. Reutilização. Resíduo. 


\section{INTRODUÇÃO}

Atualmente devido ao aumento do desenvolvimento tecnológico no setor de produção quaisquer serviços decorrentes de atividades econômicas geram uma quantidade considerável de resíduos.

Segundo Lovato (2007), o problema ambiental tem sido debatido em diversas áreas do conhecimento, por sua vez diversos setores da sociedade têm tentado melhorar sua forma de produzir a fim de reduzir o impacto provocado por eles.

Os resíduos sólidos merecem destaque, pois representam a maior parcela entre os resíduos gerados, e quando gerenciado de forma errada, ocasiona o surgimento de problemas de caráter sanitário, social e ambiental. Possuir conhecimento sobre os tipos de resíduos e suas origens, considerando a sua taxa de geração, serve como base para o acompanhamento aperfeiçoado dos mesmos (KHATIB, 2005).

Segundo Leite (2001), a geração de resíduos origina-se de várias formas, uma delas é a falta de qualidade dos bens e serviços, ocasionando perda de material, o qual é retirado do canteiro na forma de entulho, provocando o aumento no volume de resíduos. Aos Resíduos da Construção Civil - RCC, unem-se os Resíduos da Construção e Demolição - RCD que podem ser provocados pelo aumento econômico e pela necessidade de manutenção, recuperação e reformas das edificações (CARRIJO, 2005).

A fim de reduzir as problemáticas provocadas pela geração excessiva de resíduos, uma opção, que vem sendo bastante utilizada é a fabricação de concretos e argamassas com agregados reciclados proveniente de RCC.

Conforme Silva et al. (2009), os concretos produzidos com RCC podem apresentar variações em suas propriedades, devido as particularidades. Além disso, a variabilidade presente neste tipo de material e suas possíveis contaminações dificultam a sua utilização, gerando resistência por parte dos construtores.

O objetivo geral da pesquisa é demonstrar a possibilidade da substituição total ou parcial do agregado natural por agregado reciclado gerado por resíduos da construção e demolição na produção do concreto estrutural.

\section{METODOLOGIA}

Metodologia científica é o estudo de métodos utilizados nas ciências, em suas explanações, validade e sua relação com as teorias científicas. Em geral, o método científico é um conjunto de dados iniciais juntamente com um sistema de operações adequado para a formulação de conclusões, de acordo com os objetivos estabelecidos (GERHARD; SILVEIRA, 2009).

A metodologia é um conjunto de procedimentos a serem utilizados pelo indivíduo na obtenção do conhecimento. É a aplicação do método, por intermédio de processos e técnicas, que garantem a legitimidade do saber obtido (GERHARD; SILVEIRA, 2008).

A metodologia aplicada nesse trabalho parte de uma revisão bibliográfica, onde foi possível ter um embasamento teórico para a utilização de agregados reciclados no concreto para fins estruturais. 0 método aplicado foi uma pesquisa quali-quantitativa, com a delimitação da área de estudo ao município de Aracaju e grande Aracaju, aplicando questionários nas obras de médio e grande porte e na empresa responsável pela coleta de resíduos sólidos no município. Segundo Costa (2008), a metodologia do multicritério permite a associação entre os fatores qualitativos e quantitativos, bem como a correta abordagem da subjetividade presente no processo de decisão.

\section{1 ÁREA DE ESTUDO}

A área de estudo estabelecida foi o município de Aracaju/SE que segundo pesquisas do Instituto Brasileiro de Geografia e Estatística - IBGE em 2018 possui uma população de aproximadamente 648.939 habitantes e uma área relativa de $181,857 \mathrm{~km}^{2}$ e os municípios limítrofes de Nossa Senhora do Socorro e Barra dos Coqueiros como representado na figura 1. 
Figura 1 - Mapa do Estado de Sergipe

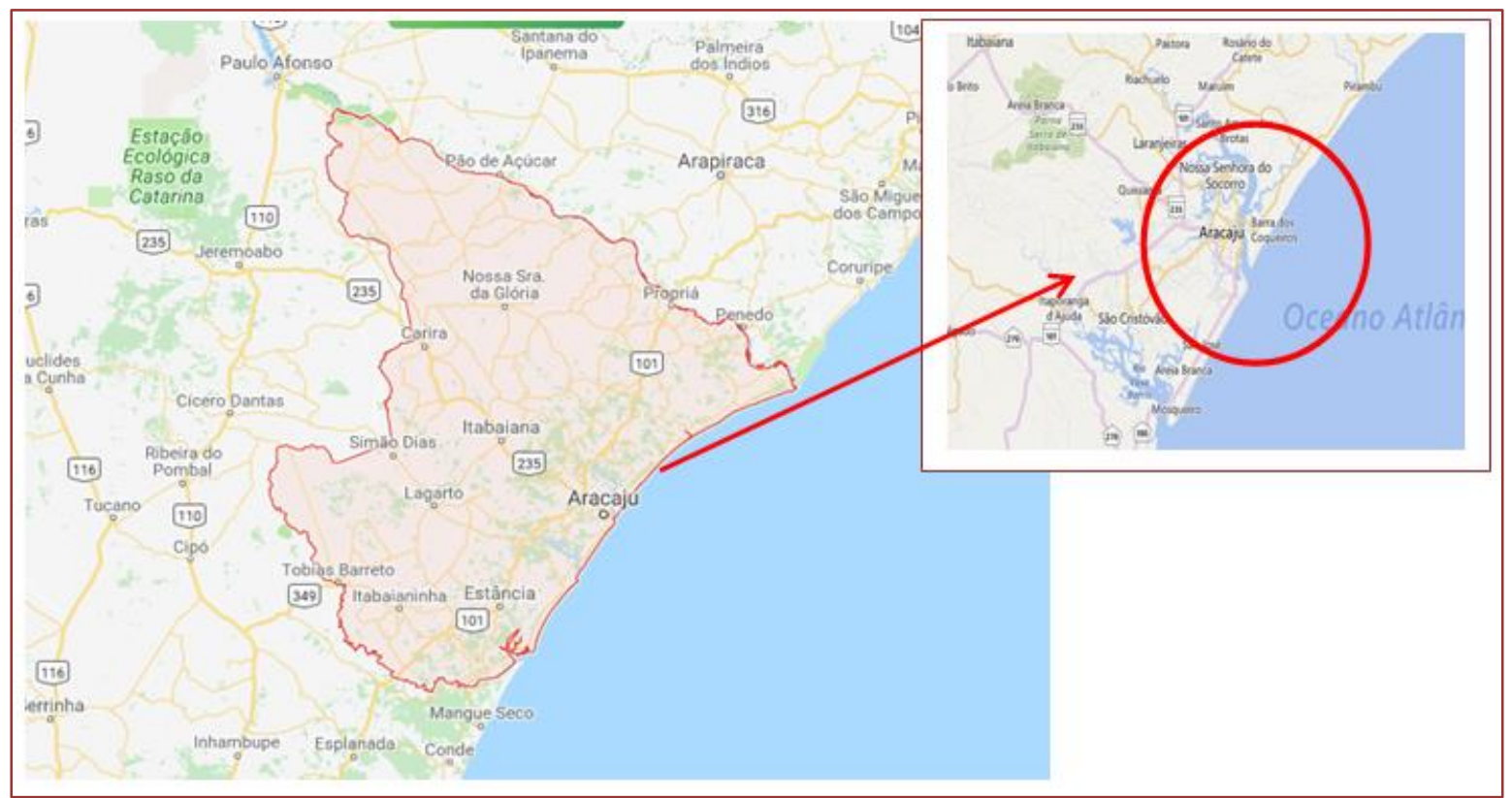

Fonte: Google Maps, 2018.

\subsection{COLETAS DE DADOS}

Por ser uma pesquisa descritiva, tem como objetivo principal, a caracterização dos agregados reciclados para fins estruturais, mostrando a possibilidade da sua utilização e seu custo/benefício.

Em busca de conhecimento e informações no primeiro momento, procurou-se concreteiras no município no intuito de encontrar alguma que produzisse e fornecesse concreto produzido com agregado reciclado de RCD, porém as que obtivemos contato não produzem este tipo de material e nunca obtiveram pedido para fabricação deste tipo de material, logo após no dia 22 de março de 2018 foi realizado uma visita a Administração Estadual do Meio Ambiente - ADEMA a fim de receber orientações sobre as exigências necessárias para que uma obra consiga produzir seu próprio agregado reciclado, a funcionária responsável pelo setor esclareceu sobre o assunto e afirmou que as exigências necessárias são as estabelecidas pelas resoluções do Conselho Nacional do Meio Ambiente - CONAMA № 237 E № 307 fornecendo uma lista da documentação necessária.

A pesquisa foi limitada às obras do município de Aracaju, Barra dos Coqueiros e Nossa Senhora do Socorro. Para este estudo, foram consideradas todas as obras de médio e grande porte, aplicando no total de 15 questionários.

Do dia 14 a 23 de maio de 2018 foram aplicados questionários nas obras de médio e grande porte na área que foi delimitada para realização da pesquisa, cujo objetivo foi coletar informações sobre o uso de agregados reciclados para fins estruturais.

o Terceiro momento seria a aplicação de um questionário no aterro da empresa de coleta de resíduos sólidos no município de Aracaju, cujo objetivo era levantar as informações necessárias sobre a coleta, segregação, tratamento e armazenamento dos RCD's, cuja visita não ocorreu devido a falta de retorno da empresa ao ofício enviado pela Instituição Pio Décimo e inúmeras ligações e e-mails enviados.

A pesquisa bibliográfica foi desenvolvida através da leitura sobre tema desta pesquisa, ou seja, agregados reciclados oriundos de RCD's, que a partir de livros técnicos, Constituição Federal, Decretos, Leis Complementares e Normas nortearam presente estudo e buscou responder o que deve ser feito para que o uso de agregado reciclado realmente faça sua parte do contexto da sociedade, levantando com isso um dos principais problemas que é o impacto ambiental feito pelo descarte irregular.

A pesquisa faz uma análise embasada na situação real do problema abordado, buscando soluções para inserir este tipo de material. Os instrumentos de pesquisas utilizados foram: observação visita a órgãos do município, aplicação de questionários e registros fotográficos. 


\subsection{ANÁLISES DOS DADOS}

Para fazer a verificação sobre o uso de agregados reciclados para fins estruturais, os dados coletados em campo foram passados para planilha eletrônica onde foram analisados através de gráficos para melhor compreensão. Desta forma, a pesquisa, sendo quali-quantitativa, proporciona uma análise das questões observando os principais aspectos. Apresenta-se a seguir os resultados dos dados coletados.

\section{RESULTADOS E DISCUSSÃO}

Esta seção foi dividida em três partes. A primeira apresenta resultados obtidos nas concreteiras, a segunda com as informações geradas através da pesquisa de campo em obras de construtoras consideradas de médio e grande porte e o terceiro momento com as informações obtidas na empresa de coleta de resíduos sólidos do município de Aracaju.

Os resultados abaixo presentes nas figuras a seguir, foram gerados através de um questionário aplicado em sete concreteiras do município, os resultados obtidos não foram muitos satisfatórios devido à resistência de algumas empresas em responder as perguntas elaboradas como mostrado na figura 2, porém as respostas obtidas foram de suma importância para notarmos que as concreteiras aqui existentes não produzem concreto com as características necessárias para este trabalho.

Figura 2 - Gráfico da quantidade de empresas procuradas e quantas responderam ao questionário

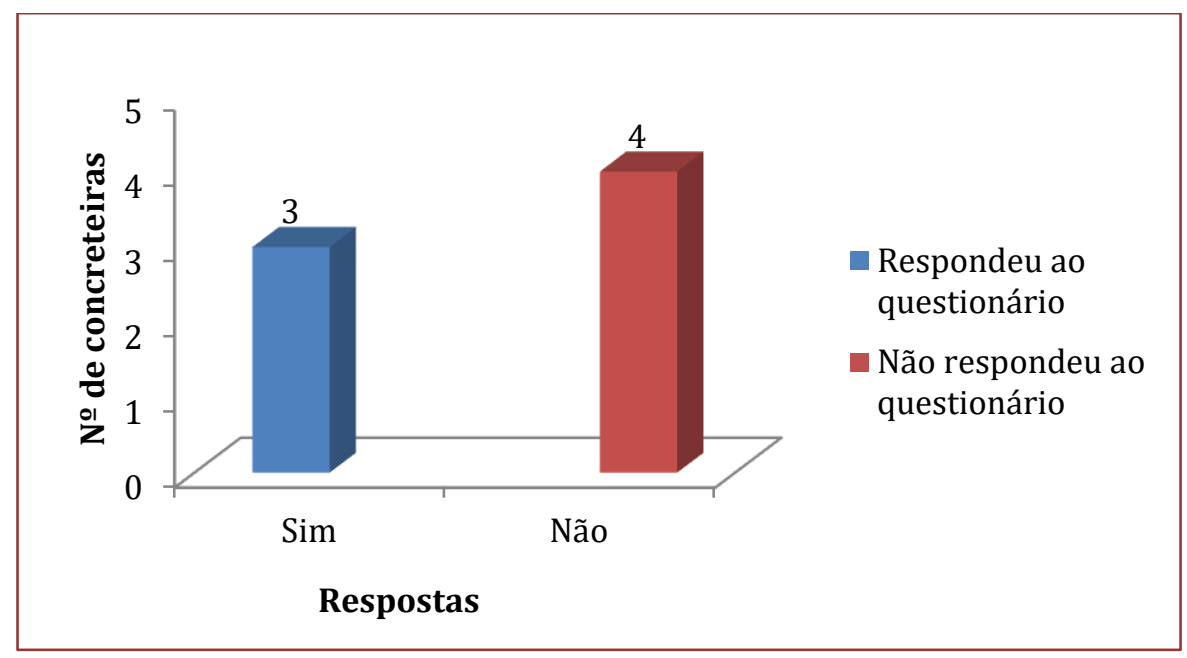

Fonte: Dados da pesquisa, 2018.

Fazendo a análise das respostas percebemos que as empresas procuradas não produzem concreto reciclado por não terem solicitação por meio das construtoras existentes no município, como está representado na figura 3. 
Figura 3 - Gráfico das concreteiras que produzem concreto reciclado

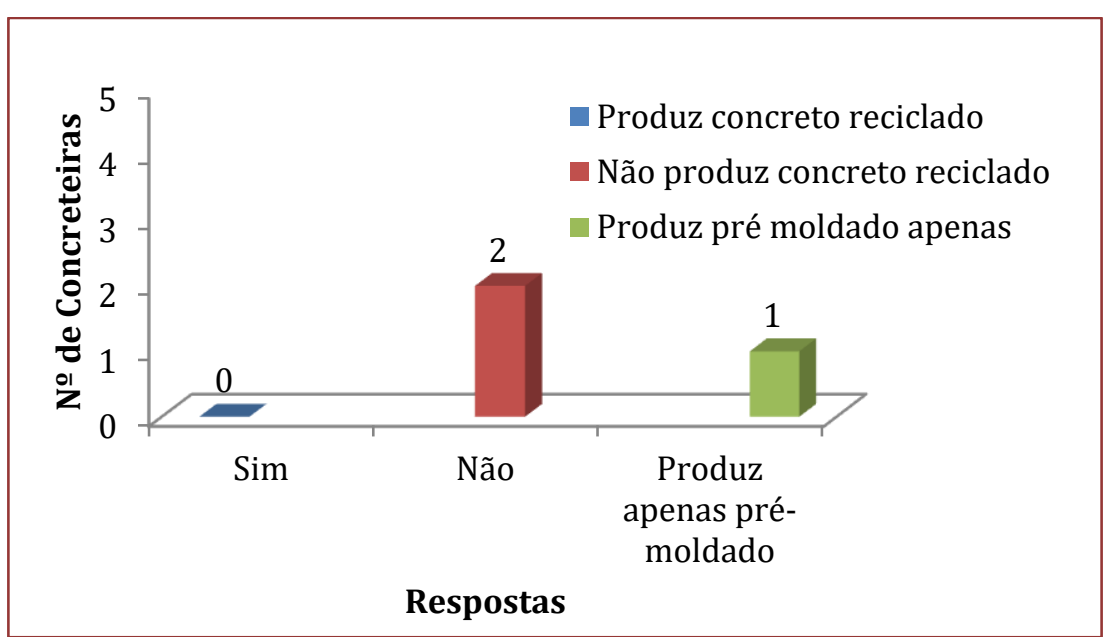

Fonte: Dados da pesquisa, 2018.

Quando questionadas sobre o uso de agregados reciclados as mesmas tiveram a mesma resposta, não fazem o uso de agregado reciclado para a produção de concreto como mostrado na figura 4 e todas afirmaram que o agregado utilizado por ela é oriundo de jazidas como mostrado na figura 5 .

Figura 4 - 0 gráfico representa a solicitação de concreto composto por agregado reciclado

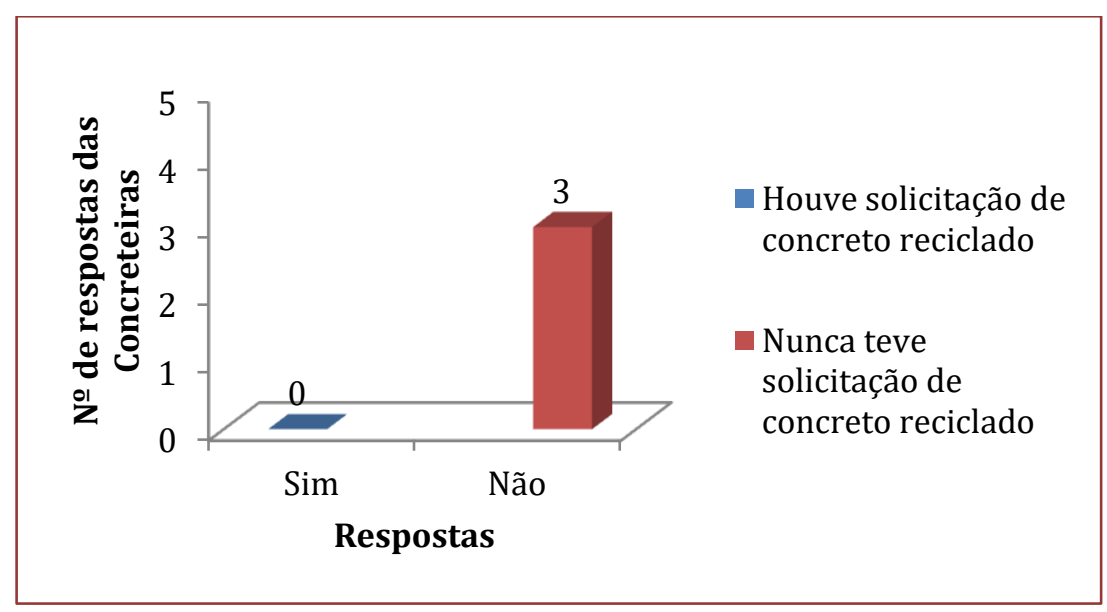

Fonte: Dados da pesquisa, 2018. 
Figura 5 - Gráfico relacionado à origem do material utilizado nas concreteiras

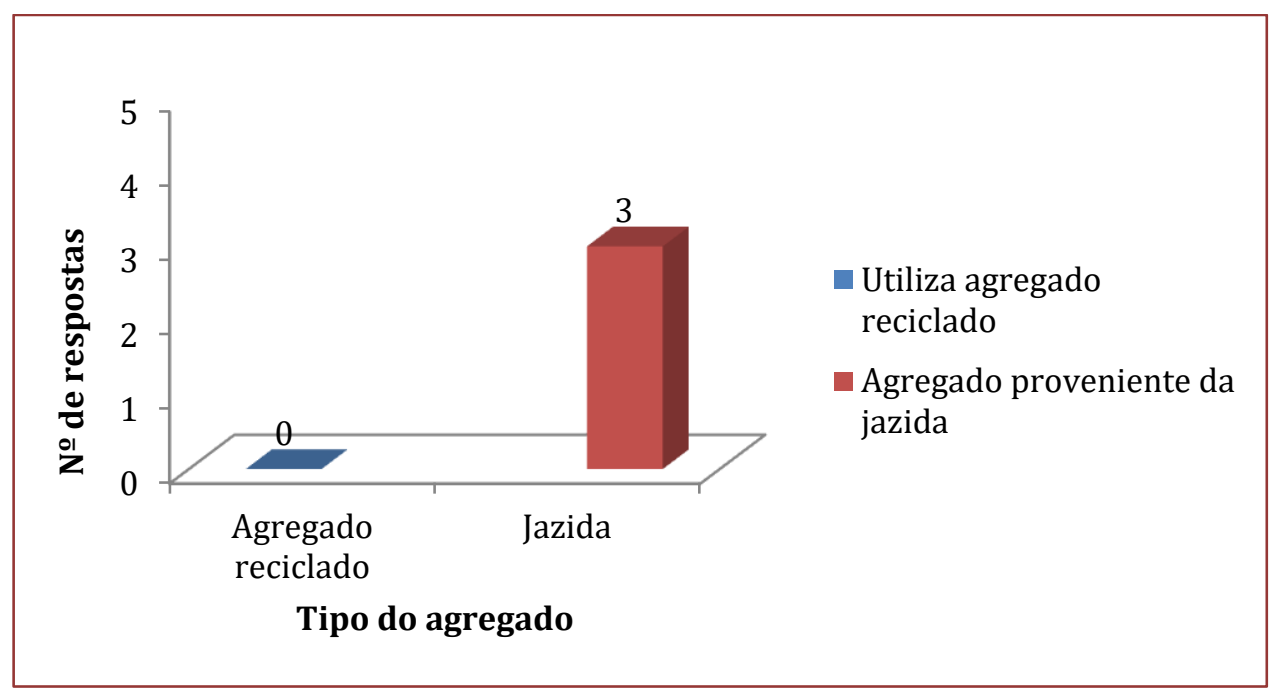

Fonte: Dados da pesquisa, 2018.

Segundo Alves e Quelhas (2004), o setor da construção civil sobressai como o principal usuário dos recursos naturais (areia, brita) e maior produtor de resíduos, sendo considerado um dos maiores causadores de impactos ambientais, isso é perceptível no gráfico acima.

O uso de resíduos contribuiria de forma positiva para a diminuição do uso de insumos da construção civil resultante de 3 processos de britagem de rochas, britas e areia artificial, tornando-se uma importante ferramenta no combate a degradação ambiental (OLIVEIRA; MENDES, 2008).

Na segunda etapa os resultados foram obtidos através de pesquisa aplicada em obras de médio e grande porte, o número de questionários a serem aplicados resultaram de um levantamento do número de obras que estão sendo executadas na área delimitada deste trabalho que correspondem a 50 obras, destas foram retiradas 15 obras que correspondem a 30\% do total em execução.

Apesar da dificuldade de ter acesso as obras o tempo foi otimizado através da aplicação deste questionário através do aplicativo Google formulários onde foram elaboradas perguntas, alternativas de respostas e espaços para respostas subjetivas, facilitando a aplicação do questionário quando havia algum tipo de resistência do engenheiro em responder o questionário físico elaborado.

Os resultados a seguir presentes nas figuras abaixo, foram resultantes das respostas dos responsáveis técnicos pelas obras entrevistadas. A figura 6 demonstra quantas obras foram visitadas e os nomes fictícios que foram determinados a elas. Através do levantamento feito é notado que o maior número de obras se concentra em Aracaju como mostrado na figura 7. 
Figura 6- Gráfico referente ao número de obras visitadas por construtora

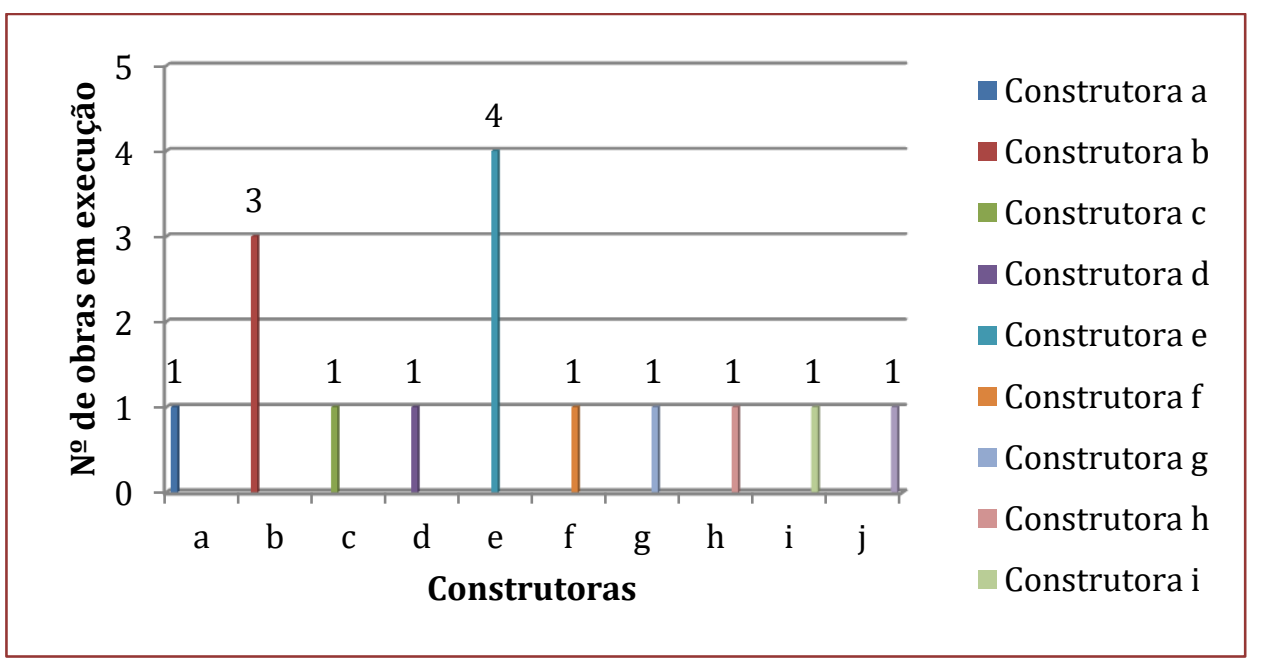

Fonte: Dados da pesquisa, 2018.

Figura 7 - Gráfico demonstrativo de obras visitadas nas áreas delimitadas

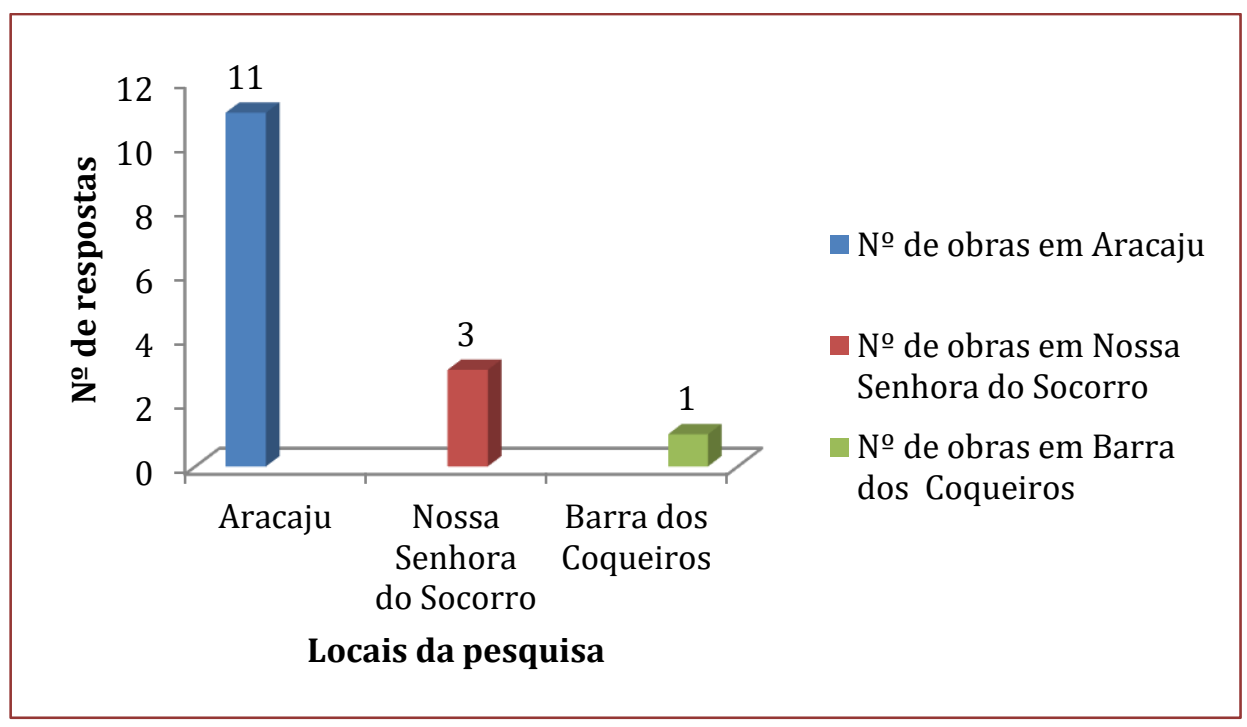

Fonte: Dados da pesquisa, 2018.

Quando questionados sobre a Resolução do CONAMA № 307, a grande maioria afirmou conhecer e seguir as exigências feitas por ela como demonstrado nas figuras 8 e 9 , porém notou-se que ainda possuem obras que não existe o controle de resíduos e engenheiros que não conhecem o que é estabelecido na Resolução, fazendo, portanto o descarte de acordo com as recomendações da construtora em que trabalha de forma irregular e prejudicial ao meio ambiente. 
Figura 8 - Gráfico referente ao conhecimento da Resolução CONAMA № 307

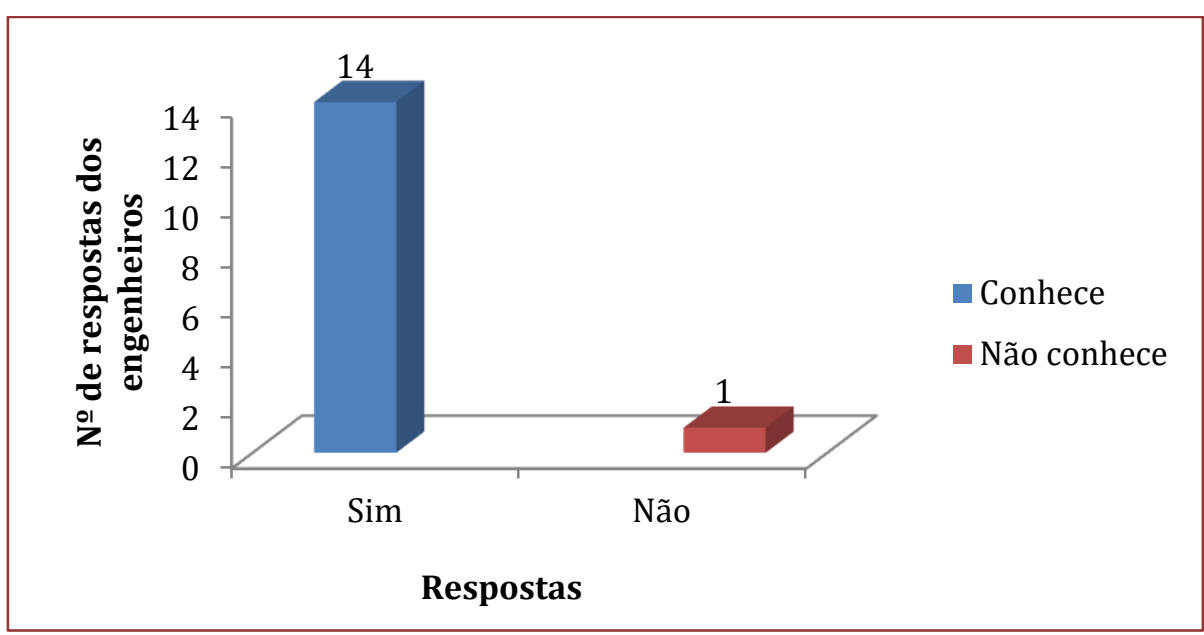

Fonte: Dados da pesquisa, 2018.

Figura 9 - Gráfico de gestão de resíduo no canteiro

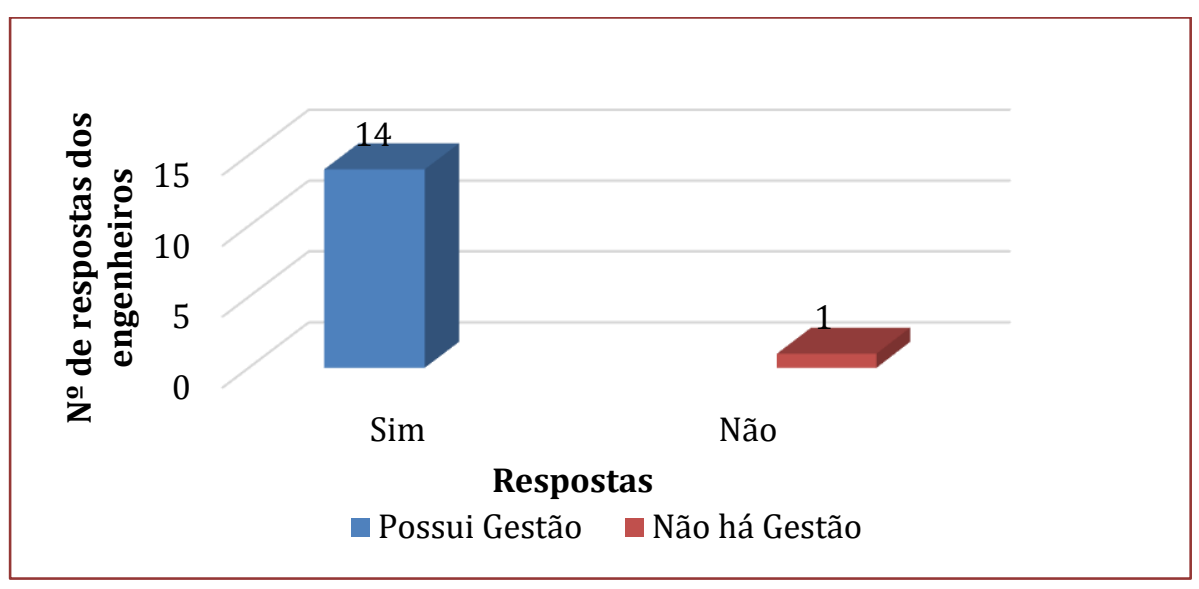

Fonte: Dados da pesquisa, 2018.

Segundo a Resolução do CONAMA № 307 de 2002, os resíduos são classificados em quatro classes (A, B, C e D), com o objetivo de promover a redução, reutilização e a reciclagem, assim como estabelece diretrizes tornando os geradores responsáveis pela a destinação final adequada. Através de dados contidos na pesquisa a maioria das obras promovem a separação de acordo com a classificação e a destinação e é feita através da empresa responsável pela coleta de resíduos no município ou por uma empresa contratada.

Conforme Oliveira e Mendes (2008), a tendência futura em uma construtora consciente, é reconhecer o princípio de quem gera o resíduo é responsável por sua separação, limpeza, armazenamento e destinação final adequada.

Os resultados da produção diária de resíduos nas obras variaram de acordo com o estágio que a obra se encontra, possuindo uma variação de produção de 5 a $10.000 \mathrm{~kg} /$ dia por obra entrevistada como demonstrado na figura 10, onde os valores estão relacionados por cada construtora. 
Figura 10 - Gráfico de geração de resíduos por obra

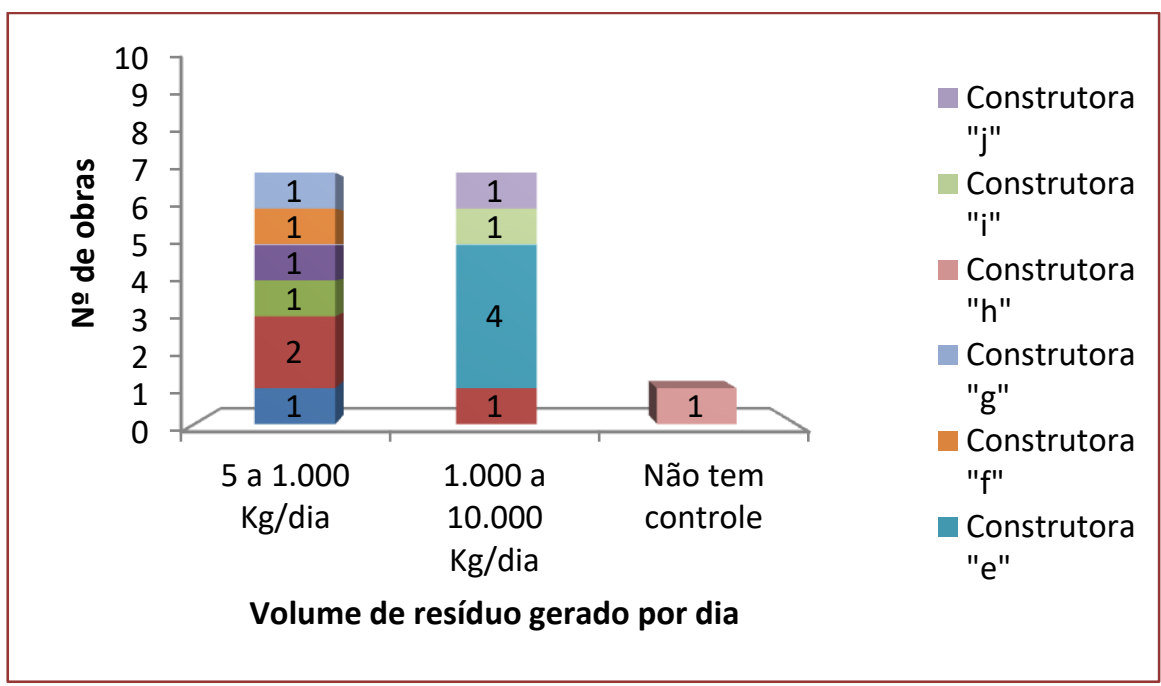

Fonte: Dados da pesquisa, 2018.

Na figura 11 notou-se que há uma aceitação sobre a utilização de agregado reciclado em concreto estrutural, porém $66,7 \%$ não possui conhecimento sobre o uso deste agregado reciclado para fins estruturais por falta de normas regulamentadoras no Brasil relacionadas ao uso de agregados reciclados provenientes de RCC no concreto com função estrutural, possuindo em vigor no Brasil apenas NBR 15116:2004 que trata sobre a utilização apenas em pavimentação e em concreto sem função estrutural como demostrado na figura 12.

A partir da década de 90, foram realizadas na Comunidade Europeia obras com concreto reciclado, este era composto por agregados reciclados de concreto, de alvenaria e por ambos (LEVY 2001), o mesmo cita obras executadas na Holanda, Inglaterra, Bélgica como citadas abaixo:

- 1988 , o $2^{-}$viaduto na Rodovia RW-32, os componentes estruturais foram executados com concreto reciclado.

- 1988 , laje submersa da Hidrovia de Haandrick, possuindo um volume de concreto reciclado igual a $2000 \mathrm{~m}^{3}$.

- $\quad$ Edifício do meio ambiente, em 1996, utilizou concreto usinado com agregados reciclados, com resistência C25 para fundação e C35 nas lajes e pilares.

- Ampliação do Porto de Antuérpia, foi executada com concreto de até $35 \mathrm{MPa}$ composto de agregado reciclado proveniente da demolição das paredes da eclusa de Zandvliet.

Conforme Muller (2006), o Comitê Alemão faz especificações relacionadas ao Concreto Armado, determinando que as propriedades do concreto reciclado sejam semelhantes às propriedades do concreto composto por agregado natural. Por sua vez essa aceitação soa de forma positiva, pois segundo Lima (2000), o processo de reciclagem influencia diretamente no desenvolvimento sustentável através de uma qualificação do processo produtivo do setor da construção civil que utilizam o agregado como insumo. 
Figura 11 - Aceitação de agregado reciclado para fins estruturais

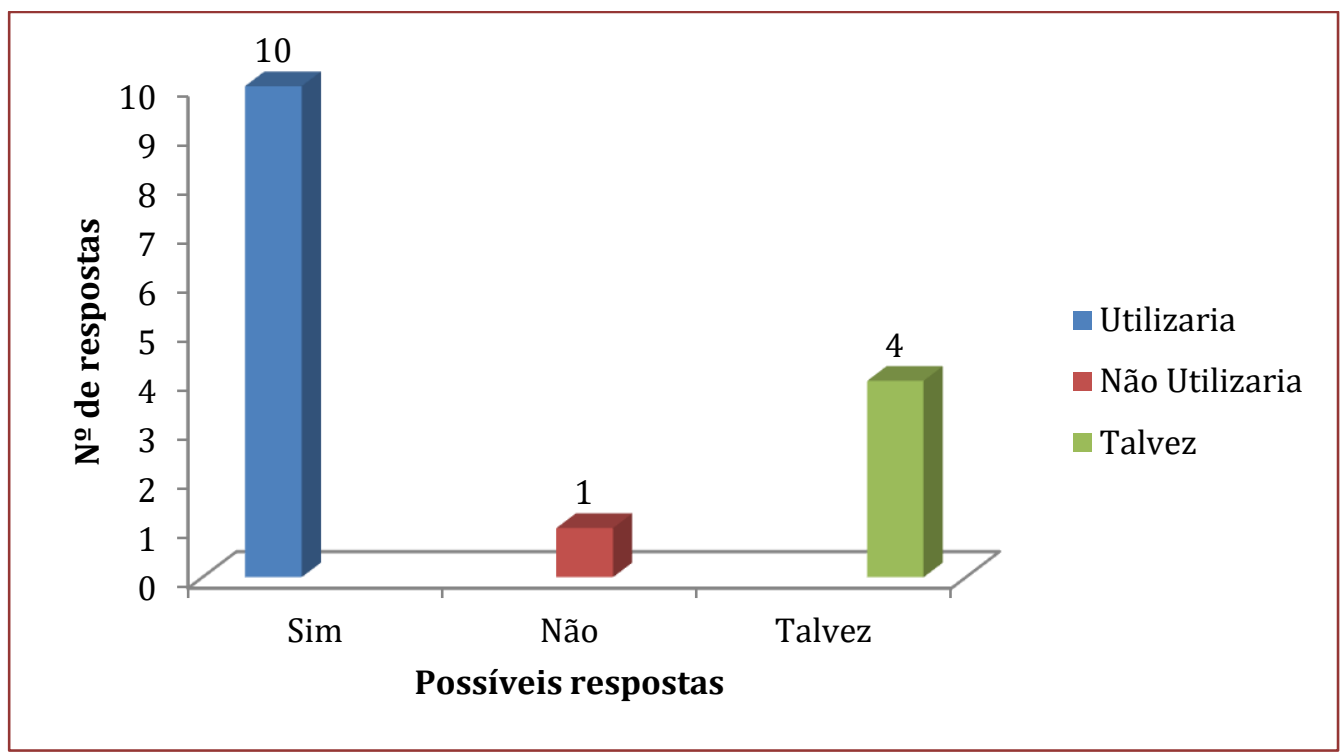

Fonte: Dados da pesquisa, 2018.

A utilização como matéria-prima ou agregado, o entulho deixaria de ser um problema, transformando-se em uma saída para a escassez de materiais granulares capazes de serem utilizados para fins estruturais (OLIVEIRA; MENDES, 2008).

Figura 12 - Gráfico indicador de conhecimento sobre agregado reciclado para fim estrutural

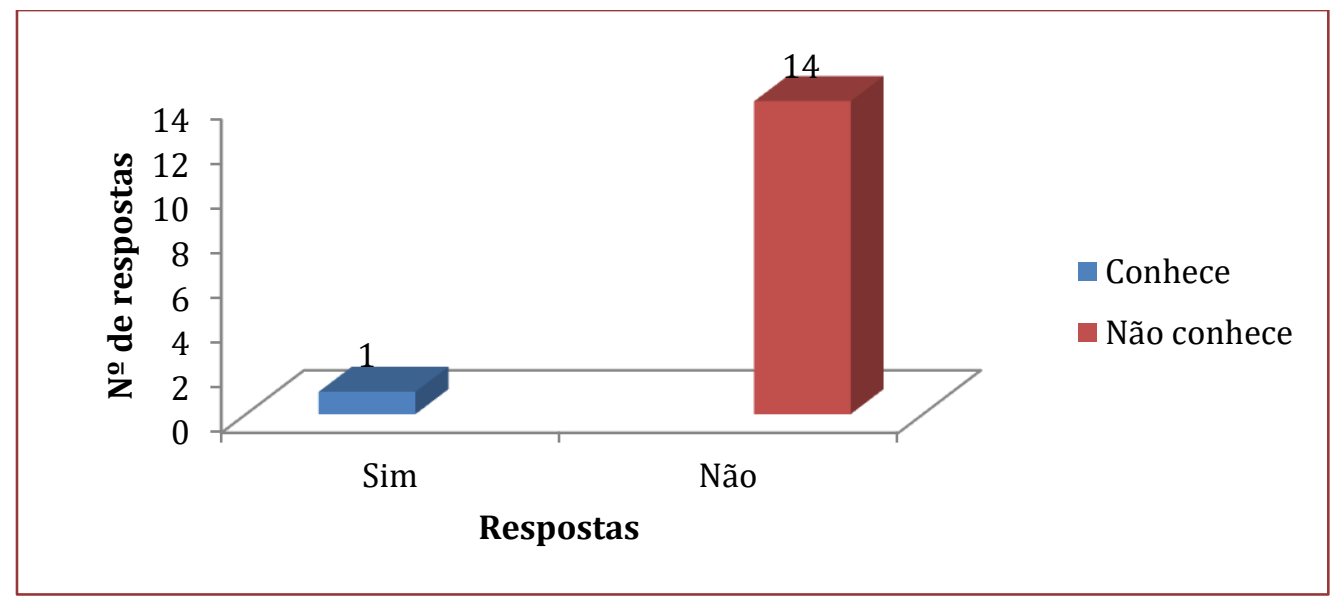

Fonte: Dados da pesquisa, 2018.

A falta de conhecimento sobre este tipo de agregado, sobre seu valor faz com que a sua utilização seja mínima, onde 93,3\% dos entrevistados afirmaram não conhecer o valor do agregado reciclado. Podemos perceber que em algumas obras existentes esse agregado é utilizado na pavimentação, em concreto magro e estas obras são quem fornece o resíduo e produz fora do seu canteiro este tipo de material.

Lauritzen (1998), afirma que o mercado de reciclagem de resíduos da construção e demolição pode ser rentável em países em desenvolvimento, principalmente quando os agregados naturais se tornarem pouco acessíveis devido à escassez.

0 terceiro momento foi à procura pela empresa de coleta de resíduos sólidos do município de Aracaju, porém a mesma não respondeu ao ofício, e-mail, solicitando uma visita ao aterro da empresa onde são produzidos agregados reciclados provenientes de resíduos da construção e demolição. Após semanas 
procurando a mesma percebi que o acesso seria inviável então foi realizado contato via telefone solicitando que algum funcionário responsável pelo setor de vendas da empresa respondesse a um questionário onde conseguiria obter informações sobre produção, uso e fornecimento de agregados reciclados. Obtive a informação que o questionário não poderia ser respondido, mas a funcionária passou a informação que a empresa produz este tipo de agregado para uso próprio, mas que não fornece mais para outras empresas.

\section{CONSIDERAÇõES FINAIS}

Há uma aceitação de mercado através dos resultados obtidos, tornando os agregados reciclados propícios para comercialização, porém existe uma falta de conhecimento sobre o agregado reciclado que por sua vez apresenta um grande potencial para fabricação de concreto estrutural, desde que sejam feitos estudos que viabilizem esta tecnologia, já que no Brasil ainda não há normatização.

Quando analisada as respostas das concreteiras nota-se que existe uma falta de procura para fabricação do produto fazendo com que as mesmas não busquem conhecimento, tornando difícil a compra de concreto reciclado no município de Aracaju.

Referente à produção de agregados reciclados pela empresa de coleta de resíduos do município observase que é possível à comercialização no estado, porém a mesma não divulga e não permite o acesso a sua área de produção.

Fica como sugestão para trabalhos futuros avaliação das propriedades de concretos reciclados com resíduos provenientes no município de Aracaju, através de ensaios em laboratórios executando um comparativo entre os resíduos coletados nas obras.

\section{REFERÊNCIAS}

[1] _.NBR 15116: Agregados reciclados de resíduos sólidos da construção civil - utilização em pavimentos e preparo de concreto sem função estrutural -Requisitos. Rio de Janeiro, 2004f.

[2] CONSELHO NACIONAL DO MEIO AMBIENTE. Brasília, 2002. Resolução CONAMA n 307, de 5 de julho de 2002. Disponível em: <http:// www.mma.gov.br/pot/conama/res/res02/res30702.html> . Acesso em: 04 de março. 2018.

[3] CONSELHO NACIONAL DO MEIO AMBIENTE. Brasília, 1997. Resolução CONAMA no 307, de 19 de dezembro de 1997. Disponível em: <http://www.mma.gov.br/port/conama/res/res97/res23797.html> . Acesso em: 04 de março. 2018.

[4] ALVES, C. E. T.; QUELHAS, O. L. G.. A ecoeficiência e o ecodesign na indústria da construção civil: uma abordagem à prática do desenvolvimento sustentável na gestão de resíduos com uma visão de negócios. Rio de Janeiro: Associação Educacional Dom Bosco, 2004. 10p. Disponível em:. Acesso em: 08 maio. 2018

[5] CARRIJO, P. M. Análise da influência da massa específica de agregados graúdos provenientes de resíduos de construção e demolição no desempenho mecânico do concreto. São Paulo: USP, 2005. Dissertação (Mestrado em Engenharia Civil), Escola Politécnica da USP, Universidade de São Paulo, 2005.

[6] COSTA, Marcela da Silva; RAMOS, Rui Antônio Rodrigues e Silva, Antônio Nelson Rodrigues (2008). Um índice de Mobilidade Urbana Sustentável para cidades brasileiras.

[7] GERHARD, Dra. Tatiana Engel; SILVEIRA, Dra. Denise Tolfo. Métodos de Pesquisa. Porto Alegre: Apostila, 2008. 121 p. Disponível em: <http://www.ufrgs.br>. Acesso em: 15 abr. 2018.

[8] GERHARD, Dra. Tatiana Engel; SILVEIRA, Dra. Denise Tolfo. Métodos de Pesquisa. Porto Alegre: Editora da Ufrgs, 2009. 120 p. Disponível em: <http://www.cesadufs.com.br>. Acesso em: 15 abr. 2018.

[9] IBGE. População. Disponível em: <https://cidades.ibge.gov.br/brasil/se/aracaju/panorama>. Acesso em: 06 dez. 2018.

[10] KHATIB, J. M. Properties of concrete incorporanting fine recycled aggregate. Cement and Concrete Research, [S.1.], n. 35, p. $763-769,2005$. 
[11] LAURITZEN, E.K. The global challenge of recycled concrete. In: DRHIR, R.K; HENDERSON, N.A.; LIMBACHIYA, M. C. (Eds.). Sustainable Construction: Use of Recycled Concrete Aggregate. London: Thomas Telford Pub, 1998b. p. 505-519.

[12] LEITE, M. B. Avaliação de propriedades mecânicas de concretos produzidos com agregados reciclados de resíduos de construção e demolição. 2001. 290p. Tese (Doutorado em Engenharia). Programa de Pós-graduação em Engenharia Civil. Universidade Federal do Rio Grande do Sul, Porto Alegre.

[13] LEVY, S. M. Contribuição ao estudo da durabilidade de concretos produzidos com resíduos de concreto e alvenaria. 2001. 199f. Tese (Doutorado) - Escola Politécnica, Universidade de São Paulo, São Paulo, 2001.

[14] LIMA, J.A.R. Aggretade obtained from C\&D waste recycling. Proposition of specification for use in concrete. In: CIB SYMPOSIUM IN CONSTRUCTION AND ENVIRONMENT: THEORY INTO PRACTICE, 2000, São Paulo, Brazil. Proceedings... [CD-ROM]. São Paulo: CIB, 2000. 6p.

[15] LOVATO, P. S.. Verificação dos parâmetros de controle de agregados reciclados de resíduos da construção e demolição para utilização em concreto. 2007. 182 f. Dissertação (Mestrado) - Curso de Engenharia Civil, Universidade Federal do Rio Grande do Sul, Porto Alegre, 2007.

[16] MÜLLER, A. Closed loop of concrete rubble? In: SEMINÁRIO DE DESENVOLVIMENTO SUSTENTÁVEL E A RECICLAGEM NA CONSTRUÇÃo CIVIL, 7., 2006, São Paulo. Anais... São Paulo: Comitê Técnico CT-206 Meio Ambiente (IBRACON), 2006, CD-ROM. (palestra apresentada durante o evento).

[17] OLIVEIRA, E. G. de; MENDES, Osmar. GERENCIAMENTO DE RESÍDUOS DA CONSTRUÇÃO CIVIL E DEMOLIÇÃO: ESTUDO DE CASO DA RESOLUÇÃO 307 DO CONAMA. 2008. Disponível em: <https://s3.amazonaws.com/academia.edu.documents/>. Acesso em: 13 jun. 2018.

[18] SILVA, C. A. R. "Estudo do agregado reciclado de construção civil em misturas betuminosas para vias urbanas". Diss. Mestrado, Universidade Federal de Ouro Preto, MG (2009).

[19] APUD ${ }^{1}$ DEUTSCHE INSTITUT FUR NORMUNG (DIN). DIN 4226-100: aggregates for mortar and concrete - part 100: recycled aggregates. Germany, 2002. 


\section{Capítulo 5}

\section{Automatização do processo de catalogação das origens de manifestações patológicas, em especial fissuras \\ Lana Laís Pereira da Cruz. \\ Romário de Jesus Santos}

Resumo: Dentre as anomalias patológicas que surgem em uma habitação, as fissuras são as que apresentam maior ocorrência, se apresentando através de quadros persistentes e que em muitos casos recorrentes mesmo após a realização de reparos recentes, indicando que tais ações foram apenas paliativas sem sanar efetivamente as causas deflagradoras. Diante da complexidade dos fenômenos envolvidos no processo que deflagram os sintomas de um problema construtivo, torna-se crucial um estudo minucioso e criterioso a fim de diagnosticar a gênese das anomalias. Com a evolução e avanço da tecnologia, os dispositivos móveis tornaram mais fáceis o acesso às informações e solucionamento de problemas, além de difundir o conhecimento. Tal funcionalidade pode ser agregada para diversas áreas da ciência, inclusive no âmbito da engenharia civil, em especial no diagnóstico de patologias construtivas. 0 referido trabalho se ateve ao desenvolvimento de uma aplicação na área de patologia das construções utilizando técnicas de programação. 0 aplicativo desenvolvido assenta numa ferramenta facilitadora para determinação preliminar de diagnósticos de quadros fissuratórios. A metodologia adotada consistiu basicamente em pesquisa bibliográficas para recolha de dados, tratamento dos mesmos e implementação das informações no Ambiente de Desenvolvimento Integrado (IDE, do inglês Integrated Development Environment) escolhido, Android Studio. Através dos resultados obtidos foi possível concluir que o protótipo desenvolvido se mostrou funcional e dinâmico com os seus usuários, cumprindo assim o papel para o qual foi idealizado. Entretanto, cabe destacar que o aplicativo desenvolvido não substitui as demais etapas do processo de investigação e análise das manifestações patológicas (em especial, fissuras) tais como a realização da busca do histórico da edificação (anamnese) e realização de ensaios adicionais e/ou complementares.

Palavras-chave: Fissuras. Patologia das construções. Aplicativos. 


\section{INTRODUÇÃO}

Segundo Thomaz (2007), dentre as diversas manifestações patológicas que atingem as edificações, as fissuras são um dos problemas mais corriqueiros e de suma importância, uma vez que evidenciam três pontos fundamentais: o aviso prévio de um estado perigoso quanto à estabilidade da estrutura, nível de comprometimento do desempenho da obra ao longo da sua utilização e o constrangimento psicológico despertado nos usuários.

A utilização de dispositivos móveis está cada vez mais em ascensão e têm considerável potencial para difusão de conhecimento, tal funcionalidade pode ser agregada para diversas áreas do conhecimento, inclusive no âmbito da engenharia civil. Tais ferramentas tecnológicas podem facilitar e tornar mais eficientes as tarefas a serem desenvolvidas e podem contribuir consideravelmente no diagnóstico de patologias construtivas.

O público alvo desta ferramenta são principalmente profissionais da área da engenharia e arquitetura, buscando promover uma maior facilitação ao acesso à certa gama de informações, sem que o profissional tenha habilidades e domínio acerca de linguagens e programação de softwares. 0 aplicativo desenvolvido assenta numa ferramenta facilitadora para determinação preliminar de diagnósticos de quadros fissuratórios.

0 referido trabalho teve como objetivo geral, a automatização do processo de catalogação das origens de manifestações patológicas, em especial, fissuras. Como objetivos específicos buscou-se catalogar informações em literaturas consagradas a cerca de configurações típicas de fissuras, identificar os requisitos mínimos exigidos de aplicações móveis, modelar os elementos e componentes do sistema utilizado na aplicação e implementar o protótipo desenvolvido.

\section{METODOLOGIA}

O presente estudo é composto por basicamente quatro etapas que consistem na recolha bibliográfica de forma mais aprofundada sobre fissuras, posteriormente a construção da matriz e fluxogramas do aplicativo e por fim, a determinação do ambiente de desenvolvimento e processo de implementação do aplicativo. Com o intuito de coletar dados para alimentar o software, foi realizado o cruzamento de informações com as principais conFigurações de fissuras em alvenarias, vigas e lajes contidas em literaturas já consagradas.

Para análise e tratamento dos dados, com o intuito de organizá-los e encadeá-los logicamente para serem implantados de fato em um aplicativo, e posteriormente para a efetiva implementação, foram adotadas as etapas de desenvolvimento conforme a sequência da Figura 1:

Figura 1: Etapas de tratamento dos dados e desenvolvimento do aplicativo

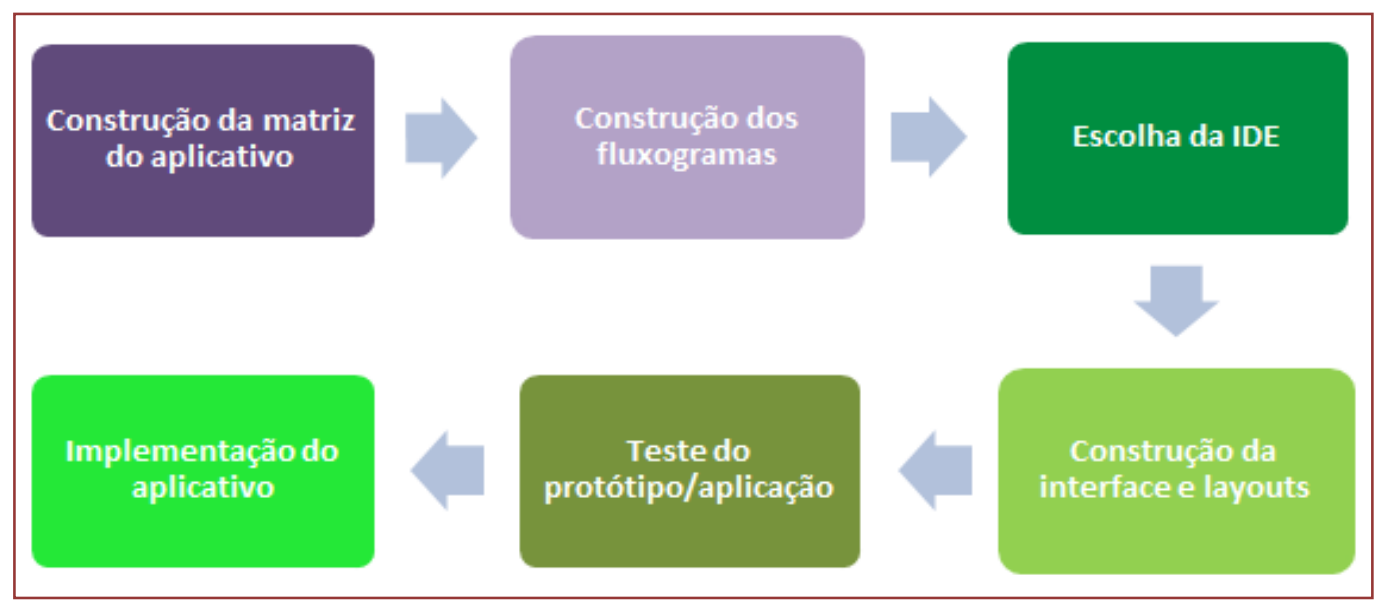


Com o intuito de facilitar a visualização foram produzidas representações operacionais e esquemáticas do algoritmo do aplicativo através de fluxogramas e da construção da matriz/árvore do aplicativo (utilizando o programa AutoCad - ferramenta de desenho gráfico). Posteriormente, a etapa seguinte consistiu na ponderação entre as IDE's (do inglês, Integrated Development Environment) existentes e escolha da mais adequada. Para o desenvolvimento do aplicativo, objeto central deste trabalho, foi utilizado como ambiente de desenvolvimento, o IDE Android Studio.

Através do IDE foi desenvolvida toda a interface do aplicativo, especificamente na aba Design do Android Studio. No próprio ambiente de desenvolvimento foi desenvolvida também a criação de várias telas (layouts), as mesmas foram vinculadas e encadeadas seguindo uma ordem hierárquica e lógica já traçadas nos fluxogramas. O encadeamento dos eventos e layouts, bem como as funções atreladas a cada componente vinculado nos layouts, foram feitas através de códigos na linguagem JAVA e implantadas na aba MainActivity do Android Studio.

Para a validação do funcionamento do aplicativo desenvolvido foi utilizado um emulador instalado chamado Genymotion, que funciona paralelamente e é compatível com o IDE Android Studio, e também um aparelho da plataforma Android conectado ao computador por uma interface USB (do inglês, Universal Serial Bus). Através do funcionamento do aplicativo no emulador e no dispositivo móvel foi possível visualizar o sistema em execução por etapas e por fim, a execução da aplicação concluída.

\section{RESULTADOS E DISCUSSÃO}

\section{Aplicativo FissurApp}

O aplicativo desenvolvido foi intitulado de FissurApp. A funcionalidade central de tal aplicação assenta num conjunto de escolhas feitas ao usuário, embasadas na comparação das conFigurações típicas das fissuras apresentadas pelo aplicativo com as fissuras reais. 0 aplicativo FissurApp não necessita que o dispositivo móvel esteja conectado à Internet, tendo em vista que todo o banco de dados utilizado está contido no próprio aplicativo. De acordo com Ribeiro (2017), a utilização de versões offlines tem sua relevância, uma vez que possibilitam o uso em qualquer ambiente independente da disponibilidade de internet, além disso, a interatividade off-line pode atrair um maior número de utilizadores.

Ao acessar o aplicativo, o usuário é direcionado para a tela inicial (Figura 2) que contêm o slogan (identidade visual do aplicativo), o botão "Ir para referências", o botão "I-Informações" e o botão "Iniciar". Ao clicar no botão "Ir para referências" são trazidas a tela as referências dos dados utilizados no aplicativo. Escolhendo o botão "Informações" é trazido à tela informações básicas da desenvolvedora e do orientador do trabalho. Ao clicar no botão "Início", o usuário é direcionado a uma nova tela (layout) onde é questionado sobre qual é a área onde foi desencadeada a fissura real, concomitantemente é disponibilizado três opções para a escolha do usuário (Figura 3).

Figura 2: Tela inicial do aplicativo FissurApp

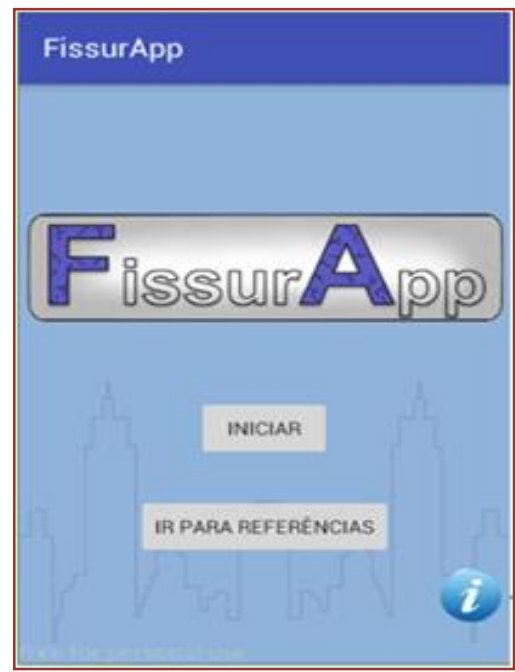


Figura 3: Sucessão de telas ao clicar no botão "Iniciar"

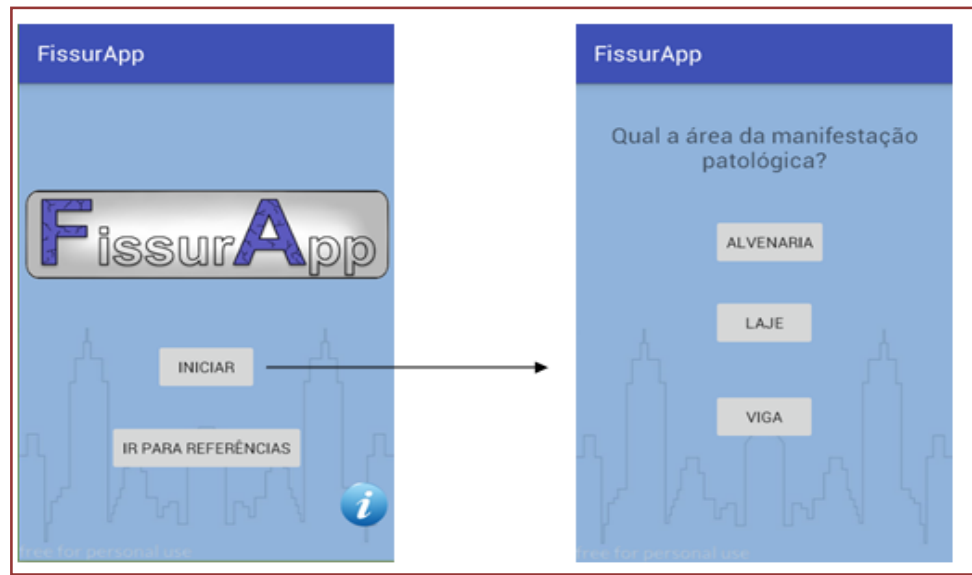

No segundo plano do botão "Início", o usuário ao selecionar qualquer uma das categorias apresentadas é encaminhado para uma tela, onde é questionado ao usuário o posicionamento relativo da fissura (no caso de ser selecionado o botão "Alvenaria" - Figura 4), a face de desenvolvimento da fissura (no caso de ser selecionado o botão "Lajes" - Figura 5), e a conFiguração da fissura (no caso de ser selecionado o botão "Vigas" - Figura 6).

Figura 4: Sucessão de telas ao clicar no botão "Alvenaria"

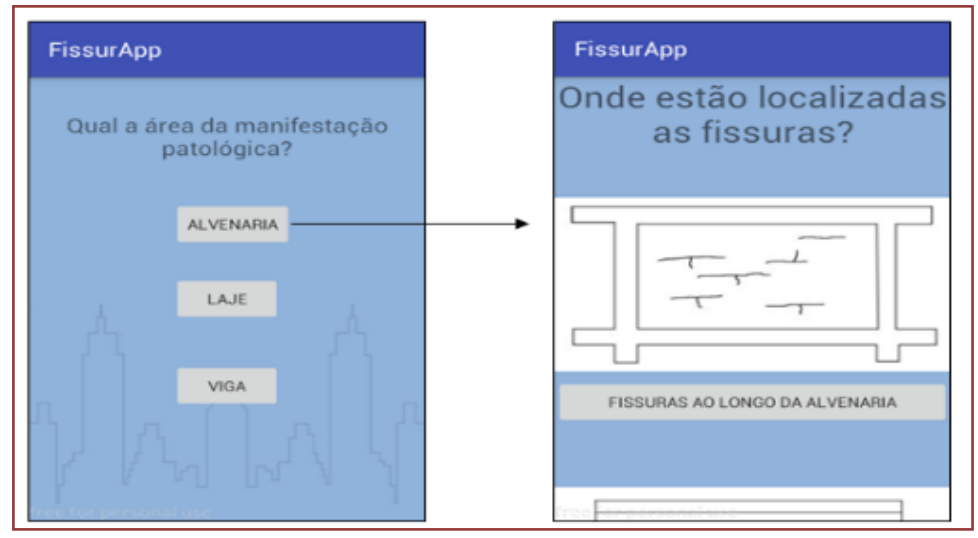

Figura 5: Sucessão de telas ao clicar no botão "Laje"

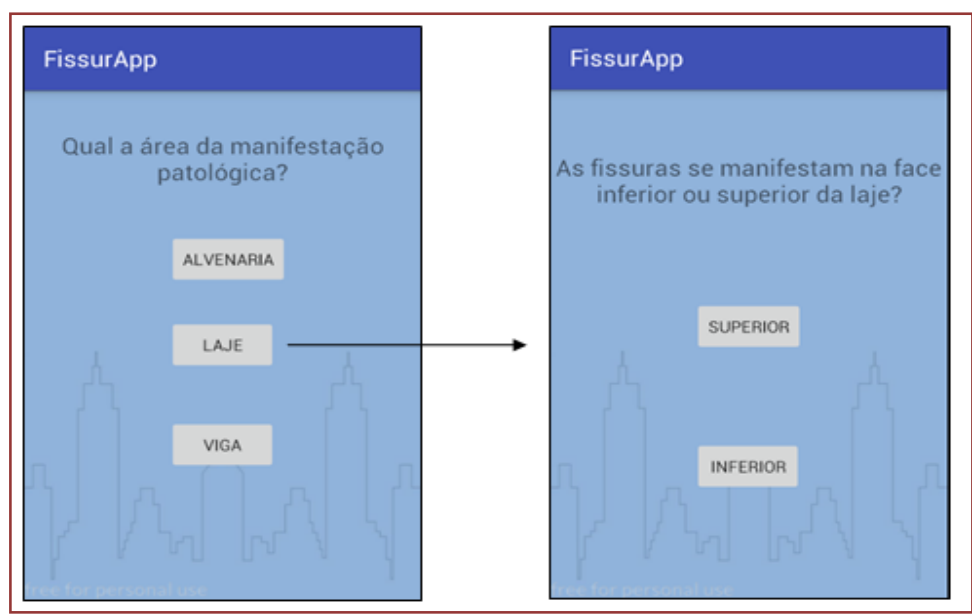


Figura 6: Sucessão de telas ao clicar no botão "Viga"

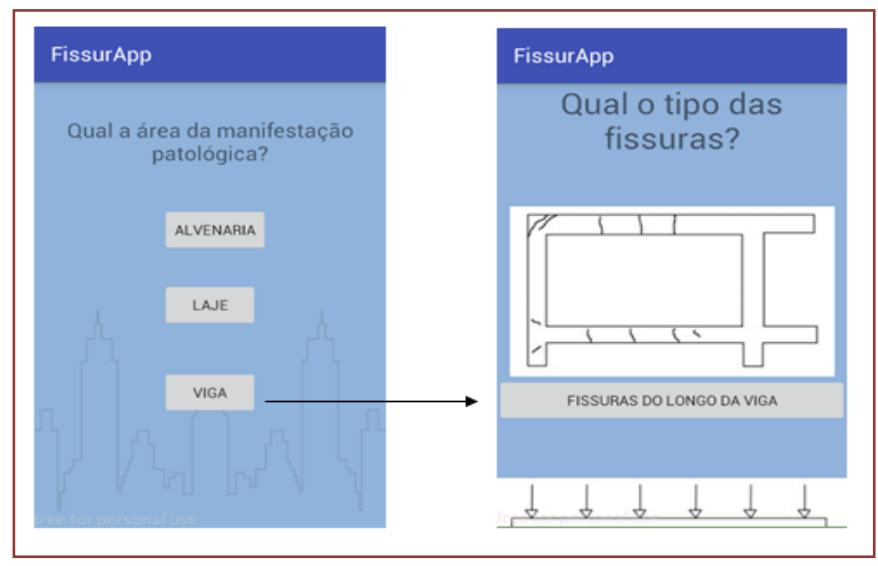

Cabe destacar que a interface do sistema utiliza o Touch do aparelho e conta com menus deslizantes (ScrowViews), onde ao selecionar qualquer ponto da tela e desliza para baixo ou para cima é fornecido mais opções existentes na tela para o usuário, conforme Figura 7. Segundo Duarte Filho (2013), a utilização de aplicativos vinculados ao toque e a disposição automática das informações estão entre algumas das características mais evidenciadas e impactadas no usuário.

Figura 7: Exemplo de um dos menus deslizantes implantado no FissurApp

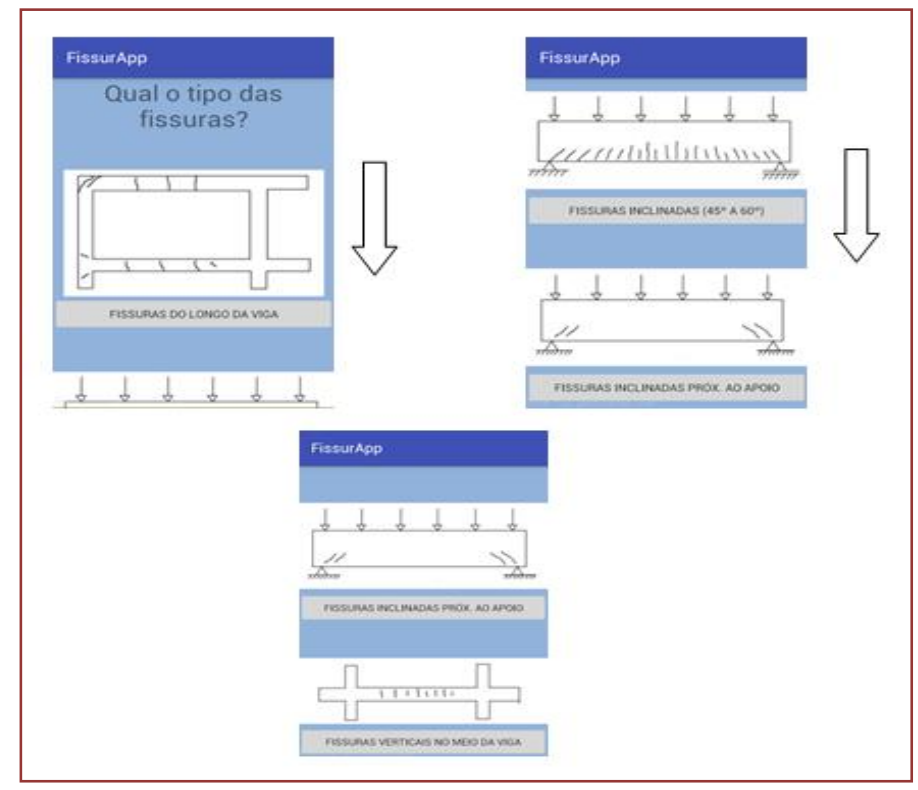

O surgimento de determinadas telas na interface do aplicativo é estritamente vinculada à escolha do usuário de tal forma que dependendo da opção selecionada, o usuário poderá ser direcionado diretamente para a exibição das possíveis causas e origens da fissura em questão (Figura8) ou ser encaminhados para telas com outros questionamentos a fim de afunilar as possibilidades e gerar um diagnóstico com maior acurácia (Figura9). 
Figura 8: Sucessão de telas encaminhando diretamente para possíveis causa e origens da fissura

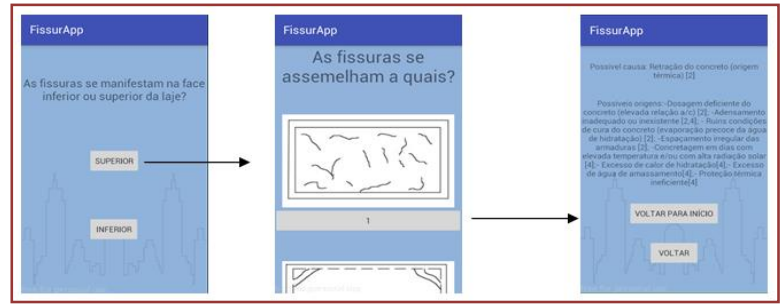

Figura 9: Sucessão de telas encaminhando a questionamentos e posteriormente para possíveis causa e origens da fissura

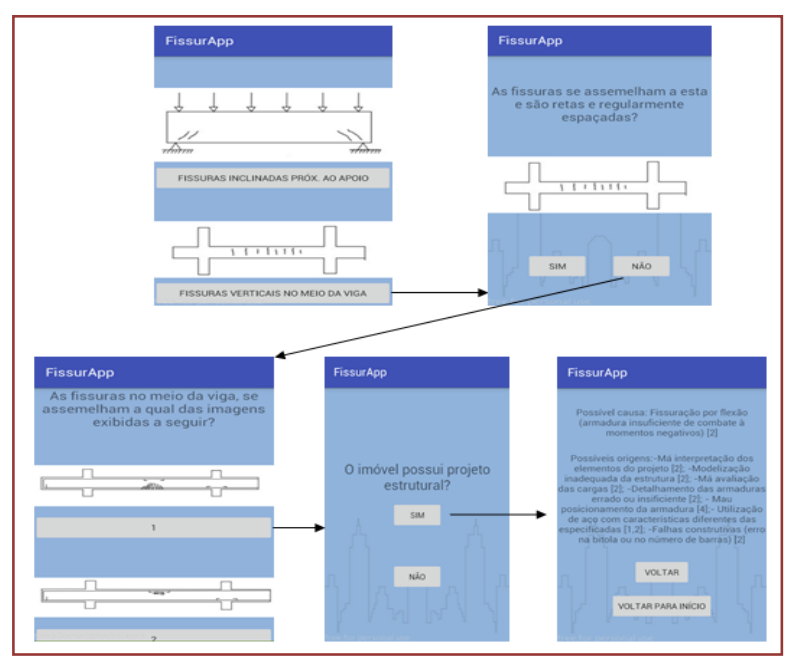

\section{CONCLUSÃO}

Conclui-se que, o protótipo desenvolvido se mostrou funcional e dinâmico, cumprindo assim o papel para o qual foi idealizado. 0 aplicativo proposto fornece informações rápidas, importantes e consistentes acerca de conFigurações típicas de fissuras, fornecendo subsídios básicos e iniciais para a realização de um possível diagnóstico da manifestação patológica. Entretanto, cabe destacar que o aplicativo desenvolvido não substitui as demais etapas do processo de investigação e análise das manifestações patológicas (em especial, fissuras) tais como a realização da busca do histórico da edificação (anamnese) e realização de ensaios adicionais e/ou complementares.

\section{REFERÊNCIAS}

[1] Thomaz, E. Trincas em edifícios : causas, prevenção e recuperação. São Paulo: Pini, 2007

[2] Ribeiro, A.C.R. Construção de aplicativos educacionais: critérios técnicos e interativos. Revista Novas Ideias em Informática Educativa: Volume 13, 2017.

[3] Duarte, N.F. Análise e avaliação funcional de sistemas operacionais móveis : Revista de Sistemas e Computação : Volume 3, 2013. 


\section{Capítulo 6}

\section{Manifestações patológicas no terminal rodoviário Governador Luiz Garcia (Rodoviária Velha)}

\section{Hortência Irys Ribeiro Lúcio}

\section{Luciana Gomes Machado Nascimento}

Resumo: O Crescimento Urbano do Brasil, especificadamente na área de estudo, o Centro Urbano de Aracaju, ocorreu de forma acelerada nas ultimas décadas. 0 desenvolvimento urbano de uma cidade envolve diversas vertentes como econômica, política, habitacional, dentre elas, a construção de grandes edificações, que tem por principal objetivo melhorar a vida da população e acelerar o desenvolvimento das cidades. Um ponto negativo desse desenvolvimento acelerado, é que grande parcela dessas grandes e importantes edificações, após construídas, acabam por não serem preservadas, e continuam em uso apesar de poucas ações para manutenção da estrutura de uma forma geral. 0 Terminal Rodoviário Governador Luiz Garcia que é o ponto focal dessa pesquisa foi construído há mais de cinco décadas e sua situação atual é bastante preocupante em termos de segurança e preservação estrutural. A conclusão deste trabalho apresenta a situação real e visível em que a edificação se encontra, através de um estudo feito através de Levantamento Fotográfico e Mapeamento de Danos que objetiva demonstrar as áreas que possam apresentar maiores e mais graves Manifestações Patológicas.

Palavras-chave: Centro Urbano de Aracaju, Terminal Rodoviário Governador Luiz Garcia, Manifestações Patológicas. 


\section{INTRODUÇÃO}

O Brasil se desenvolveu bastante nas ultimas décadas em todos os seus aspectos. Seu Crescimento Urbano é facilmente perceptível, seja pelo crescimento populacional, econômico, ou por grandes feitos relacionado à Construção Civil, que é a responsável por transformar visivelmente o país e em geral facilita a vida da população, principalmente quando se tratam de grandes obras públicas e para a acessibilidade de todos.

Desta forma ocorreu a concepção e formação do Centro Histórico de Aracaju, formado por diversas vertentes da construção como o Edifício Estado de Sergipe (1970), Hotel Palace (1962), Rua João Pessoa (1978) e o Terminal Rodoviário Governador Luiz Garcia (1962).

Para Carvalho, Trindade e Velloso (2011), quando se trata do caso específico da área do Centro de Aracaju, o Terminal Rodoviário Governador Luiz Garcia, chamado popularmente de "Rodoviária Velha", atua em uma função importante, inclusive por localizar-se juto ao centro da capital do estado, articula os diversos locais dentro da própria cidade e articula a cidade com outros municípios do seu entorno e mesmo os mais distantes. Trata-se de um fixo urbano que acaba por exercer uma função regional de suma importância, pois ajuda a consolidar as atividades de comércio e de serviços situadas no Centro de Aracaju.

Com sua construção, que fez parte de um grande marco histórico para o estado, pois, além de ter utilizado técnicas construtivas inovadoras para a época como a utilização de Concreto Armado, esta edificação seria também a responsável pela facilitação ao acesso de visitantes diários a capital. Passaram-se então 56 anos desde sua inauguração e visivelmente não se pode notar nenhum tipo de ação mais efetiva com relação a sua conservação ou restauração.

Esta pesquisa teve por Objetivo Geral verificar e detalhar a situação atual em que se encontra o Terminal Rodoviário Governador Luiz Garcia, demarcando a ocorrência de possíveis patologias e a frequência com que cada uma delas se repete.

\section{METODOLOGIA}

Abaixo estão descritos os procedimentos utilizados na Metodologia deste trabalho, feito em etapas, inicialmente determina a Área de Estudo onde o trabalho foi realizado e suas devidas características, em seguida especifica como foi realizada a Coleta de Dados para então determinar os Resultados e suas Discussões correspondentes.

\section{1 ÁREA DE ESTUDO}

A Pesquisa de Campo foi realizada no Município de Aracaju, mais precisamente no Terminal Rodoviário Governador Luiz Garcia, de Latitude - Sul, 1054'40" e Longitude - Oeste, 37ㄴ.'18”, que está localizado no centro da cidade. Popularmente conhecida como "Terminal da Rodoviária Velha" foi inaugurada em 1962 e possui uma Arquitetura Modernista que devido à falta de reformas para sua preservação arquitetônica e estrutural vem sofrendo com desgastes. Para o Estudo de Caso foi elaborado um Relatório Fotográfico e um Mapa de Danos, visando demonstrar e comprovar a real situação da edificação em estudo.

\subsection{COLETA DE DADOS}

0 trabalho foi subdividido em quatro etapas, na primeira realizou-se um Levantamento Bibliográfico acerca dos temas Crescimento Urbano no Brasil e em Aracaju, a Importância do Centro Urbano de Aracaju e do Terminal Rodoviário Governador Luiz Garcia, Histórico sobre Construções Modernistas e feitas em Concreto Armado, além de uma Análise de Possíveis Manifestações Patológicas. Este Levantamento Bibliográfico foi realizado através de livros, artigos, dissertações de mestrado, teses de doutorado e sites.

Na segunda etapa que ocorreu ao mesmo tempo em que a primeira, houve uma pesquisa de Coletar de Dados e Informações nos devidos Órgãos (IPHAN, CEHOP e SEINFRA) que possuíssem quaisquer tipos de informações sobre a construção, reformas realizadas, ou demais tipos de informações que pudessem ter relevância.

A terceira etapa foi visitar o local do estudo em questão, analisar e verificar os pontos que apresentassem possíveis Manifestações Patológicas visíveis. 
O quarto e último passo foram a Coleta Direta de Dados, na qual baseada em Planta Baixa do Terminal Rodoviário Governador Luiz Garcia, seguiu-se todo o perímetro da edificação parte Externa e Interna, Primeiro e Segundo Pavimento. Analisou-se a presença de possíveis Patologias Visíveis, buscando principalmente a ocorrência de situações que representassem a real situação do Terminal Rodoviário.

Ao todo foram tiradas várias fotos referentes a Manifestações Patológicas, tanto da área interna da edificação quanto da área externa da edificação. Toda esta Coleta de Dados para o Relatório Fotográfico e para o Mapa de Danos foi realizada no período de 24 e 25 de Maio de 2018.

\subsection{ANÁLISE DE DADOS}

A análise dos dados deu-se pela tabulação dos dados levantados através do Relatório Fotográfico e do Mapa de Danos, foram elaborados figuras em formato de gráficos e tabelas utilizando o programa Excel, da Microsoft, para melhor visualização e interpretação dos resultados, e que auxiliaram na análise através de cruzamentos de todas as variáveis levantadas. Com a realização da pesquisa foi possível obter um diagnóstico das condições em que se encontra o Terminal Rodoviário Governador Luiz Garcia.

\section{RESULTADOS E DISCUSSÃO}

\subsection{MAPA DE DANOS}

Mapas de Danos trata-se de uma representação gráfica e fotográfica, sinóptica, onde se ilustra e discrimina, rigorosa e minuciosamente, todas as manifestações de deteriorações da edificação. Tem por objetivo sintetizar o resultado das investigações sobre as alterações estruturais e funcionais nos materiais, nas técnicas, nos sistemas e nos componentes construtivos. (TINOCO, 2009)

Diversos tipos de Manifestações Patológicas foram observadas e registradas no Mapa de Danos. Localizando diferentes elementos estruturais com seu correspondente dano, compondo dessa forma uma descrição das particularidades patológicas, associadas juntamente com as causas que lhe deram origem.

Foi realizado o Mapa de Danos de toda a edificação, tanto em seu Pavimento Superior como em seu Pavimento Térreo, tanto em sua parte externa como interna. Visando assim determinar o real estado estrutural da edificação do Terminal Rodoviário.

\subsection{MANIFESTAÇõES PATOLÓGICAS NO PAVIMENTO TÉRREO}

A representação da pesquisa realizada em campo sobre as Manifestações Patológicas presentes no Terminal Rodoviário Governador Luiz Garcia no pavimento térreo será realizada através do Mapa de Danos do Pavimento Térreo que foi produzido através de uma vistoria técnica, onde se percorreu toda a parte térrea da edificação, tanto em sua área externa quanto em sua área interna. Onde as manifestações patológicas encontradas foram de diversos tipos, tendo como principais: Infiltração, Abertura não Prevista, Armadura Exposta, Corrosão, Recalque do Solo e Perca da Camada Pictórica. As Figuras 07a e 07b abaixo representam sequencialmente a Legenda do Mapa de Danos e a Planta Baixa do Pavimento Térreo com a representação do Mapa de Danos encontrados na edificação. 
Figura 07: a) Legenda do Mapa de Danos e b) Mapa de Danos Pavimento Térreo

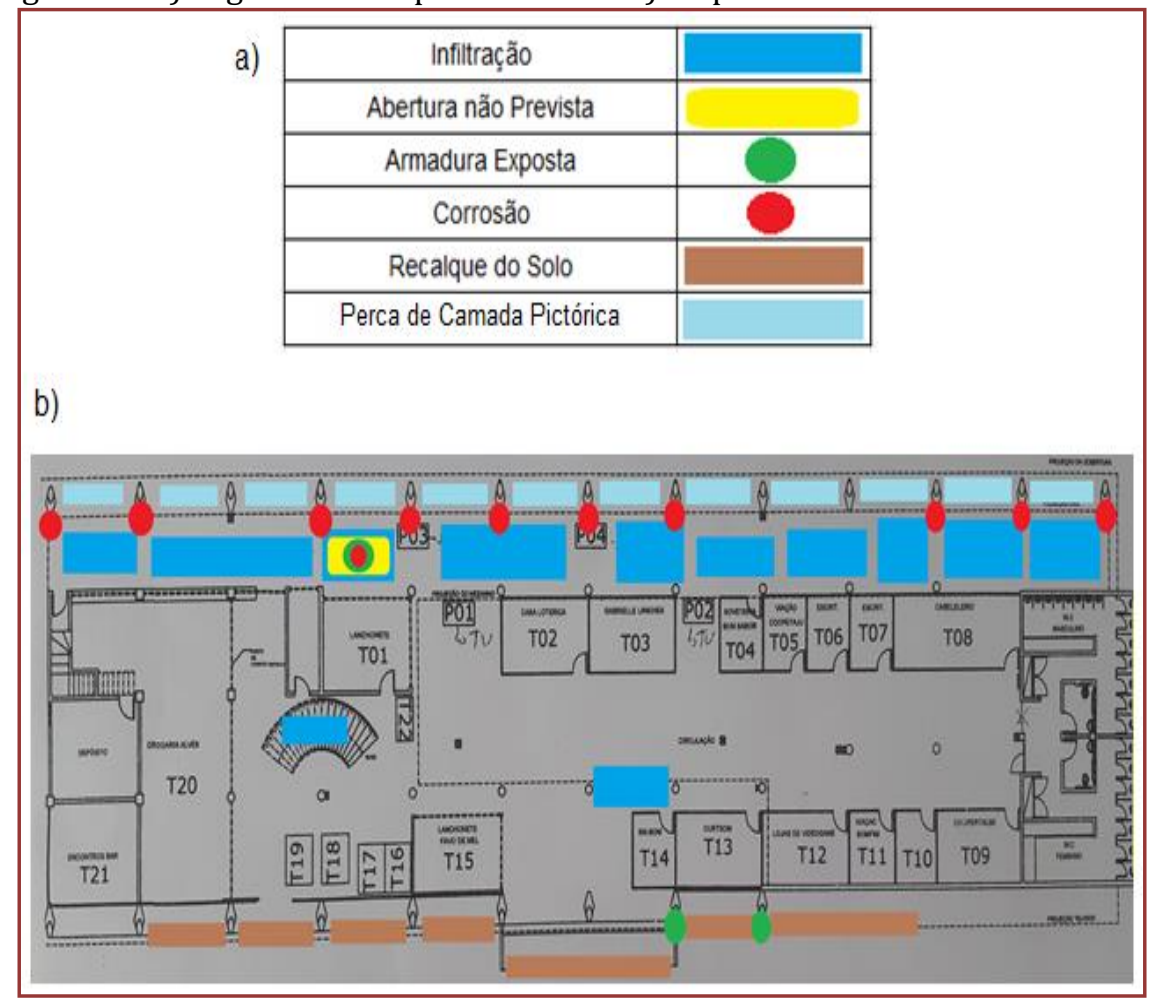

Fonte: Acervo Pessoal (2018)

Para Oliveira (2013), manifestações patológicas, salvo raras exceções, apresentam manifestação de característica externa, a partir da qual se deduz qual a natureza, origem e os mecanismos das manifestações envolvidas, assim como se podem estimar suas prováveis consequências.

A Figura 08 em formato de gráfico demonstra que é possível observar o número de ocorrências de cada Manifestação Patológica encontrada no Terminal Rodoviário Governador Luiz Garcia no pavimento térreo, podemos então subtender quais os maiores influenciadores e causadores de patologias da edificação. Se comparado com a figura anterior é possível saber as áreas mais danificadas patologicamente e quais os seus possíveis causadores.

Figura 08: Frequência das Manifestações Patológicas no Pavimento Térreo

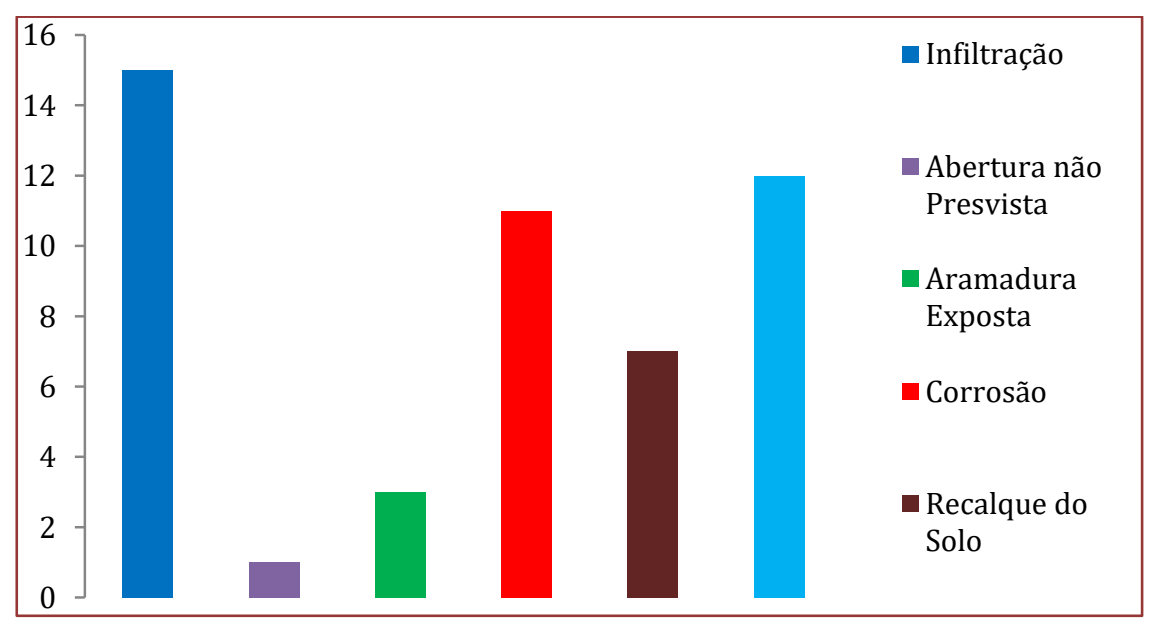

Fonte: Acervo Pessoal (2018) 
Como é possível observar através do Mapa de Danos, Figura 07b, e a Figura 08 de Frequência, a Manifestação Patológica mais frequente encontrada no pavimento térreo do Terminal Rodoviário foi do tipo Infiltração, este tipo de manifestação foi observado em quinze locais e está presente em praticamente toda laje externa do fundo da edificação, o local é destinado para ser ponto de apoio e espera dos usuários de transporte intermunicipal, abrigando diariamente centenas de pessoas. É visível que a estrutura está bastante desgastada, não exercendo assim seu devido papel de proteção e abrigo, pois em dias de fortes chuvas o local se torna inabitável devido a grande quantidade de água que escorre ao longo da laje. Infiltrações também são visíveis na área térrea da escada que dá acesso ao segundo pavimento, na laje ao seu fundo e na laje interna próximo ao T14, como mostra a Figura 09 abaixo.

"Estudos realizados no Brasil constataram que a incidência de problemas causados pela umidade nas edificações, é relativamente alta se comparada com outros tipos de problemas, chegando a até 50\%." (VITÓRIO, 2003)

Para Vitório (2003), 98\% das edificações apresentam problemas devido à infiltração, independente de a água ser totalmente pura, como a água das chuvas, pode interferir na funcionalidade do concreto devido seu acúmulo ao longo do tempo.

Figura 09: a) Área Externa, b) Parte Térreo da Escada, c) Laje ao Fundo da Escada e d) Laje Interna Próximo ao T14

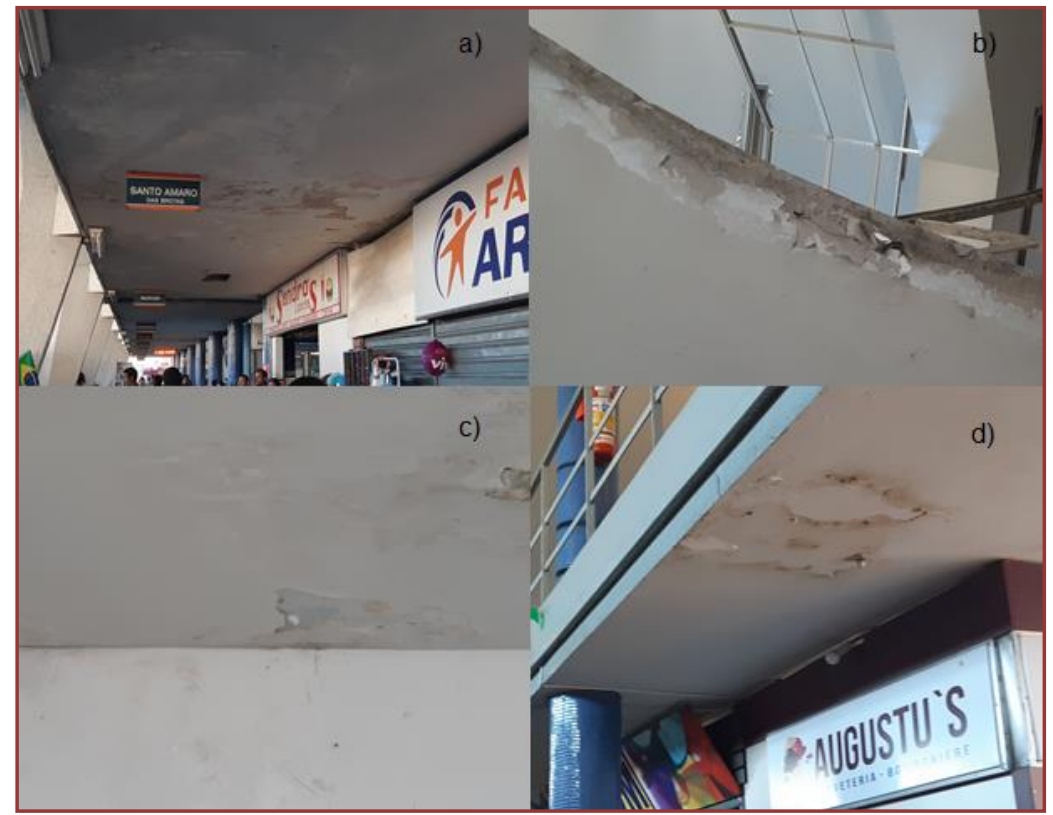

Fonte: Acervo Pessoal (2018)

O segundo tipo de manifestação mais ocorrente, sendo notado em doze locais diferentes, conforme a pesquisa realizada foi a Perca de Camada Pictórica de toda área externa do fundo da edificação, como mostra a Figura 10 abaixo. A cobertura em Aço Galvanizado foi utilizada ao longo de todo terminal para cobrir e proteger as paradas dos ônibus. A mesma se encontra sem nenhum tipo de manutenção, perdendo toda sua proteção que é responsável por proteger a estrutura de possíveis ações corrosivas, não podendo garantir suas qualidades técnicas.

Segundo Dias (2011), para garantir sua maior durabilidade e eficiência, as telhas em aço galvanizado passam por várias etapas de tratamento para garantir a proteção contra a corrosão atmosférica, a depender do uso e da construção para a qual foi especificada. As telhas que são pintadas após sua moldagem recebem uma camada eletrostática que consiste na aplicação de tinta à base de resina poliéster. Dos métodos aplicados no combate à corrosão o mais difundido é a pintura, por sua facilidade de aplicação. 
Figuras 10 e 11: Perca da Camada Pictórica / Vista da Corrosão

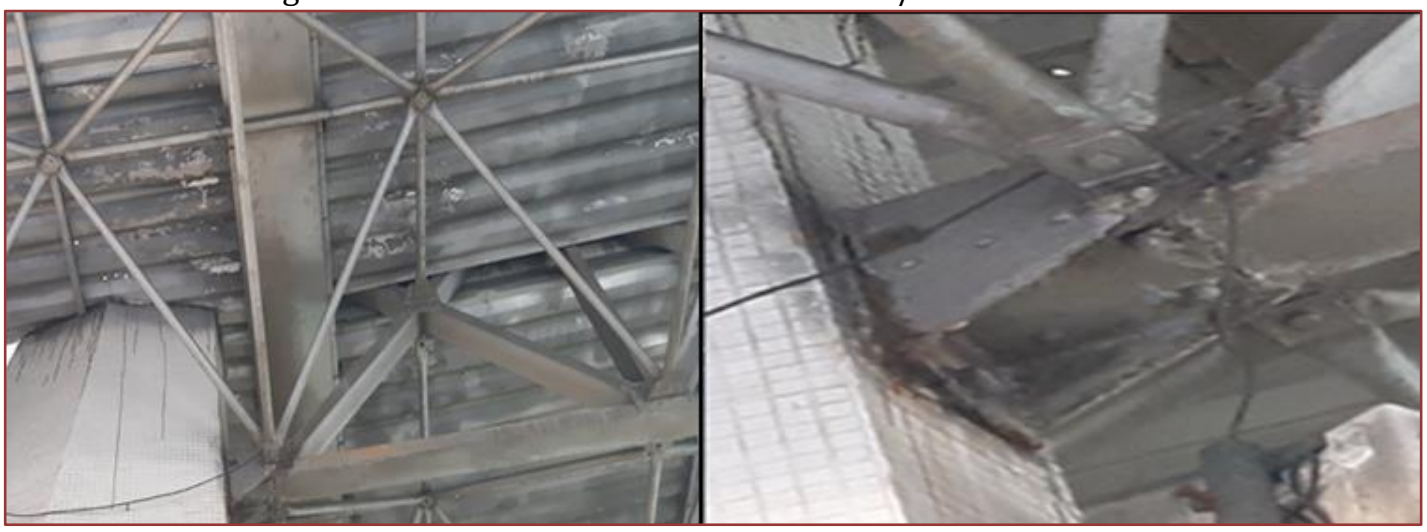

Fonte: Acervo Pessoal (2018)

Outro grave problema de Manifestação Patológica é a Corrosão principalmente de armaduras, a corrosão faz como que o aço perca suas propriedades físicas e químicas, não podendo exercer de forma eficiente seu papel na estrutura. 0 processo foi notado principalmente nos apoios que sustentam a cobertura da área externa do fundo da edificação. Observaram-se onze pontos distintos com a presença de ação corrosiva, como mostra a Figura 11 acima.

Segundo a NBR 6118/2014, o processo de deterioração das armaduras está diretamente relacionado com seu processo corrosivo, destacando-se os mecanismos de despassivação por carbonatação e a despassivação por elevado teor de íons de cloreto.

A Figura 12a e 12b representa o quarto fenômeno patológico mais notado na edificação, Recalque do Solo, o mesmo está visível ao longo de praticamente toda calçada da fachada da edificação, mesmo tendo sido usado cimento e tinta para tentar esconder determinadas patologias, mas existem ao menos sete casos com a presença de recalque. Possivelmente sua fundação passa por um processo de rebaixamento devido ao solo estar adensando.

"Os problemas mais frequentes nas fundações são causados por recalque ou ruptura do solo, por excesso de carga nas estruturas, por erosões no terreno, pela ação de agentes agressivos e pela própria inadequação da solução adotada." (VITÓRIO, 2003)

De acordo com Vitório (2003), esse tipo de patologia pode ser originado por diversos motivos, e nem sempre é fácil diagnosticar e solucionar. 0 solo é um material de grande complexidade, sua natureza pode implicar em uma grande variação de suas características.

Figura 12: a) Recalque do Solo em Pilar e b) Recalque do Solo na Calçada

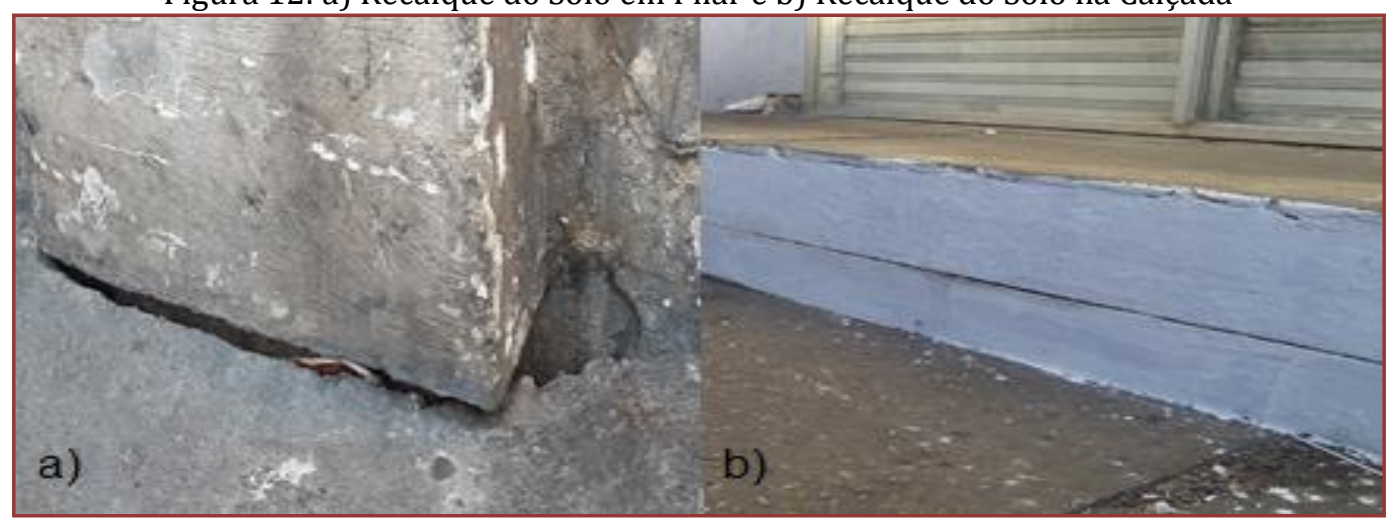

Fonte: Acervo Pessoal (2018) 
Um dos problemas patológicos mais graves para a Construção Civil é a presença de Armadura Exposta, na edificação do Terminal Rodoviário Observou-se dois casos graves de exposição de armadura. Ambos os casos estão localizados na área externa e a armadura já se encontra em estado de corrosão, um deles na fachada e o outro no fundo da edificação. Como mostra a Figura 10a, situado exatamente no apoio do pilar, tanto o revestimento cerâmico quanto o concreto responsável por proteger a armadura já foram desgastados, provavelmente esta situação se agravou devido a grande quantidade de urina humana depositada no local, deixando toda a armadura exposta. Já o da Figura 13, está localizado na laje da área externa, local também com forte presença de infiltração.

Para Monteiro et at (2013), com o tempo, as ações do tempo podem danificar até a estrutura em si. Sem o material que recobre as armaduras, as mesmas acabam ficando expostas a qualquer tipo de intervenção do meio ambiente, podendo prejudicar o seu desempenho num todo. Além disso, aumenta-se também o contato com a água que é o principal transportador dos agentes deletérios de uma edificação. Podendo agravar e acelerar o processo de corrosão da armadura.

Segundo Carmo (2009), a estrutura de concreto armado trata de um material sensível a agressividade do ambiente, principalmente no aspecto da integridade das armaduras que são as mais sensíveis às agressões do meio ambiente quando expostas.

Figura 13: a) Armadura Exposta em Pilar e b) Armadura Exposta em Laje

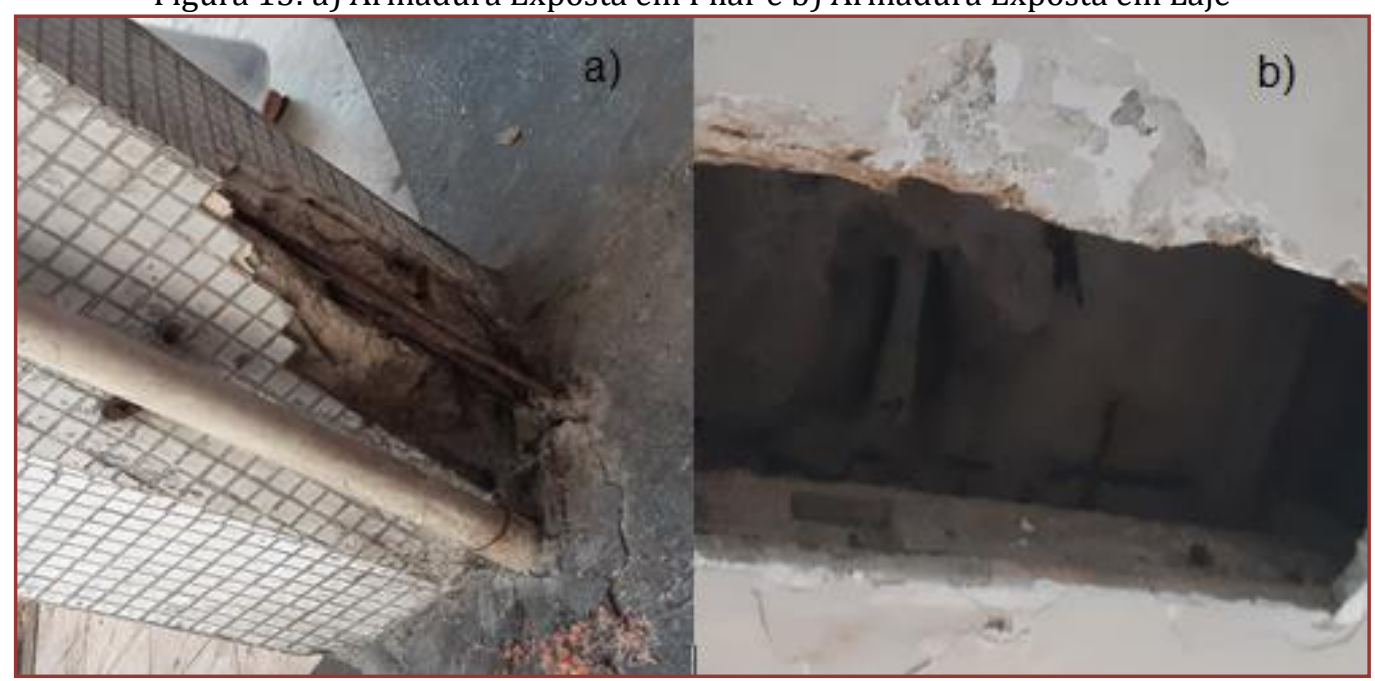

Fonte: Acervo Pessoal (2018)

\subsection{MANIFESTAÇÕES PATOLÓGICAS NO PAVIMENTO SUPERIOR}

Após observar todas as Manifestações Patológicas presentes no Pavimento Térreo, partiu-se então para o Pavimento Superior do Terminal Rodoviário Governador Luiz Garcia, a pesquisa também será representada através de Mapa de Danos da edificação que foi produzido através de uma vistoria técnica, onde se percorreu toda a área interna superior da edificação. As manifestações patológicas encontradas foram de diversos tipos, entre elas: Infiltração, Presença de Vegetação, Corrosão, Lixiviação, Rachadura e Fissura. A Figura 15a e 15b abaixo representam sequencialmente a Legenda do Mapa de Danos e a Planta Baixa do Pavimento Superior com a representação do Mapa de Danos encontrados na edificação.

A área superior da edificação possui um número de ocorrências de manifestação patológica consideravelmente menor que a área térrea, os motivos para determinado fato são vários, dentre eles a área da edificação que também é consideravelmente menor, devido uma grande abertura na laje, que contribui para complementar a arquitetura do local, tornando-a num local amplo e de fácil locomoção, além de proporcionar uma visualização gera, apesar de não possuir características para acessibilidade de deficientes físicos. Do pavimento superior é possível ter uma visão geral de basicamente toda edificação e dos seus arredores, tanto da parte interna através dessa mesma abertura estratégica da laje, quanto dos arredores da edificação, através de grandes e largas janelas presentes no local. 
Figura 15: a) Legenda do Mapa de Danos e b) Mapa de Danos Pavimento Superior

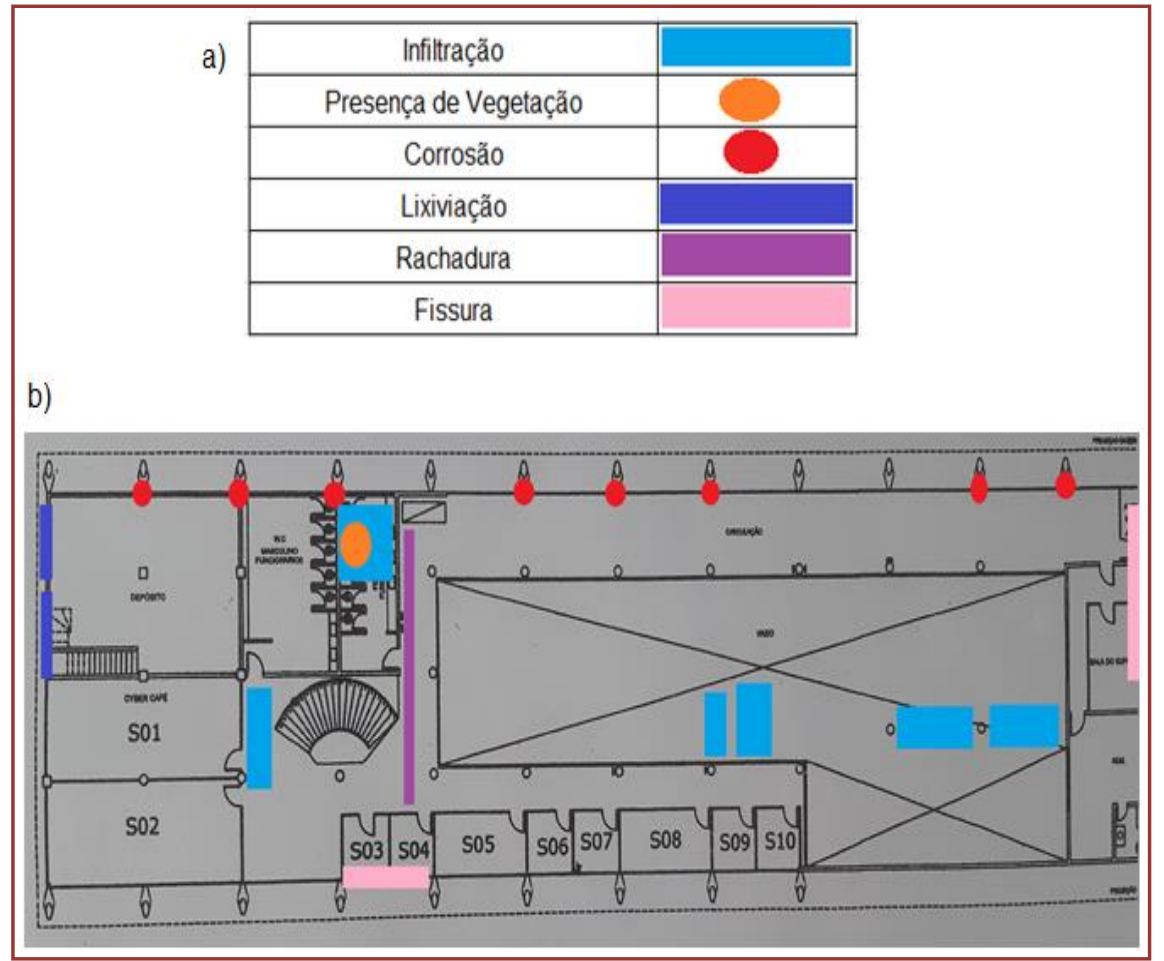

Fonte: Acervo Pessoal (2018)

Conforme Oliveira (2013), devido aos grandes indicativos de manifestações patológicas, que vêm acontecendo nas edificações, esta se buscando cada vez mais, a garantir o controle da qualidade de todo o processo de construção. Desta maneira, a qualidade final da edificação depende da qualidade dos procedimentos, das interações entre as fases da etapa produtiva e da grande retroalimentação de informações, que proporciona a melhoria contínua do produto.

Como demonstra a Figura 16 em formato de gráfico, pode-se observar o número de acontecimento de cada Manifestação Patológica situada no Terminal Rodoviário Governador Luiz Garcia no Pavimento Superior, desta forma, podemos então detectar possíveis áreas da estrutura mais afetadas e quais os prováveis causadores, assim como também uma solução para o devido problema.

Figura 16: Frequência das Manifestações Patológicas no Pavimento Superior

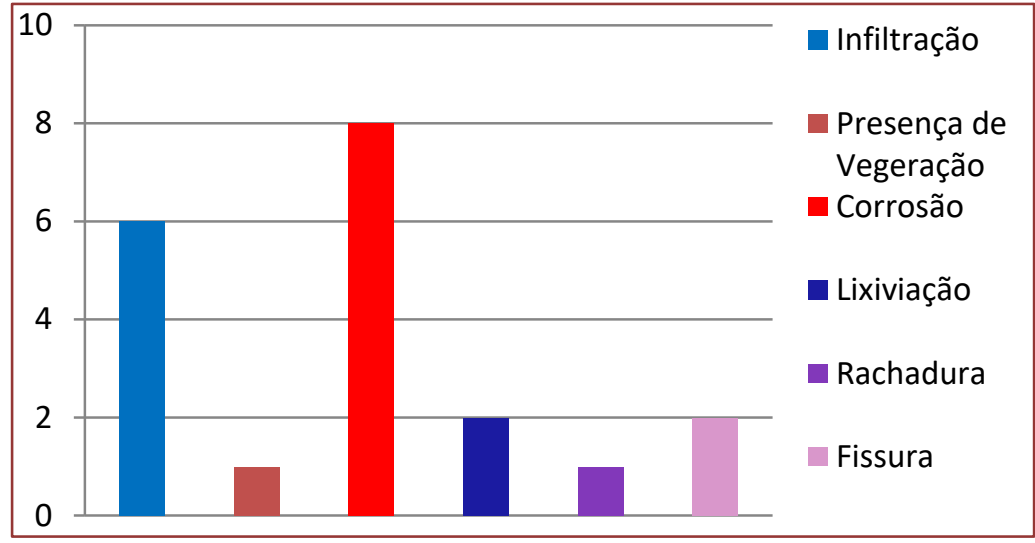

Fonte: Acervo Pessoal (2018) 
Baseando-se no Mapa de Danos (Figura 15b) e na Figura 16 acima em formato de gráfico, as manifestações que aparecem com maior frequência no pavimento superior do Terminal Rodoviário Governador Luiz Garcia, foram do tipo Corrosão, foram observadas oito ocorrências deste tipo de manifestação se faz presente de forma parcialmente generalizada em toda área de cabos e apoios de aço que suporta a cobertura, de aço galvanizado, responsável pela proteção dos ônibus em momentos de parada dos mesmos. De acordo com a Figura 16, a corrosão afeta de forma bastante severa a estrutura comprometendo que ela desempenhe seu papel de suporte corretamente, tornando-se um risco eminente para todos os que frequentam o local diariamente.

Segundo Vitório (2003), a deficiência no cobrimento faz com que a armação seja atingida mais rapidamente por elementos agressivos, acarretando, desta maneira, a sua oxidação. A parte oxidada aumenta o seu volume em cerca de aproximadamente 08 vezes. Um dos causadores mais frequentes da corrosão, é a carbonatação, que transforma o hidróxido de cálcio, com alto $\mathrm{PH}$, em carbonato de cálcio, que tem um PH mais neutro. A existência de umidade na edificação influencia bastante no avanço da carbonatação. Outro fator que também contribui para que o fenômeno se desenvolva com mais rapidez é a quantidade de $\mathrm{CO} 2$ do meio ambiente e sua permeabilidade.

Figura 17: a) Vista Lado Direito do Apoio e b) Vista Lado Esquerdo do Apoio

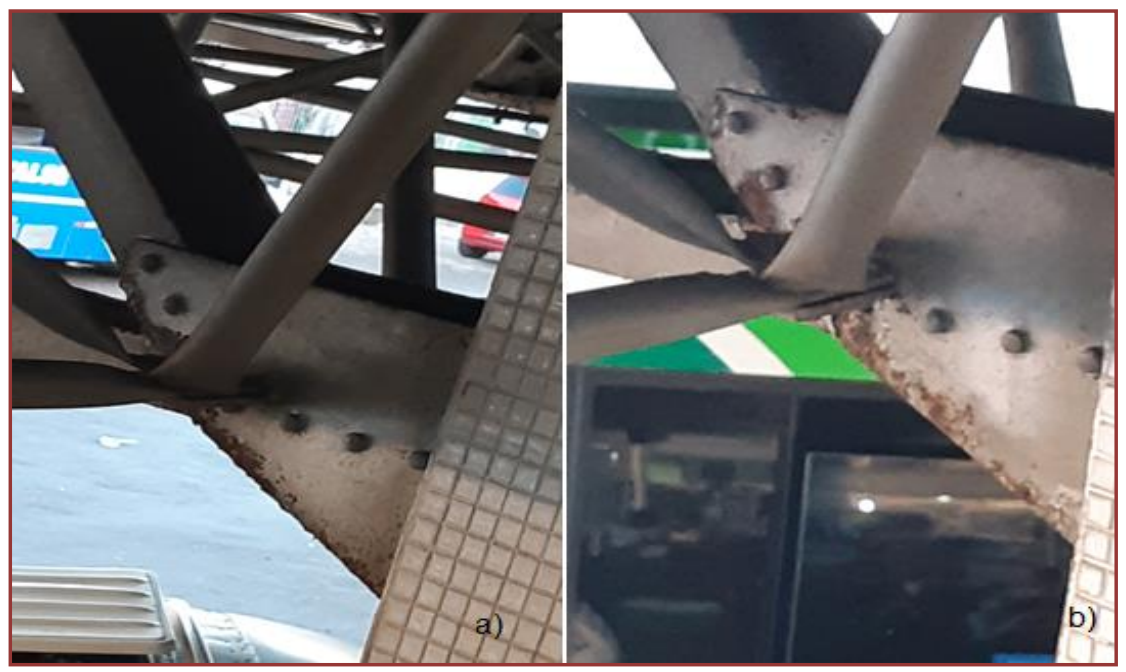

Fonte: Acervo Pessoal (2018)

Após a Corrosão, o tipo de patologia mais identificado no Pavimento Superior foi a Infiltração, sendo detectados em seis pontos. Mais uma vez observaram-se ações de infiltração por diversos pontos da laje de cobertura, muitos deles localizados juntamente aos pilares que dão apoio a estrutura e outros localizados juntamente as luminárias da edificação, o que se deduz que em dias chuvosos a água escoa junto aos pilares e pelas luminárias. 0 risco de um grave acidente é bastante eminente, tanto pelo fato da umidade prejudicar a durabilidade das estruturas de concreto armado e sua funcionalidade, quanto porque ao longo de toda área da edificação existem fiações expostas, podendo ocasionar um incêndio, como mostra a Figura 18 abaixo.

Mesmo sendo uma água totalmente pura, como no caso de águas da chuva, podem agredir o concreto através de ação da infiltração e do acumulo de água na estrutura ao longo do tempo. A presença de umidade na edificação pode ter diversas origens, essencialmente pelas fachadas e cobertas. Entre os diversos tipos de umidade citadas, a umidade por infiltração é a que apresenta maior ocorrência, chegando a aproximadamente $60 \%$. A infiltração de água nas fachadas e coberturas pode ser intensificada a depender da intensidade e direção dos ventos e da chuva. (VITÓRIO, 2003) 
Figura 18: a) Infiltração Vista Próxima e b) Vista de Longe

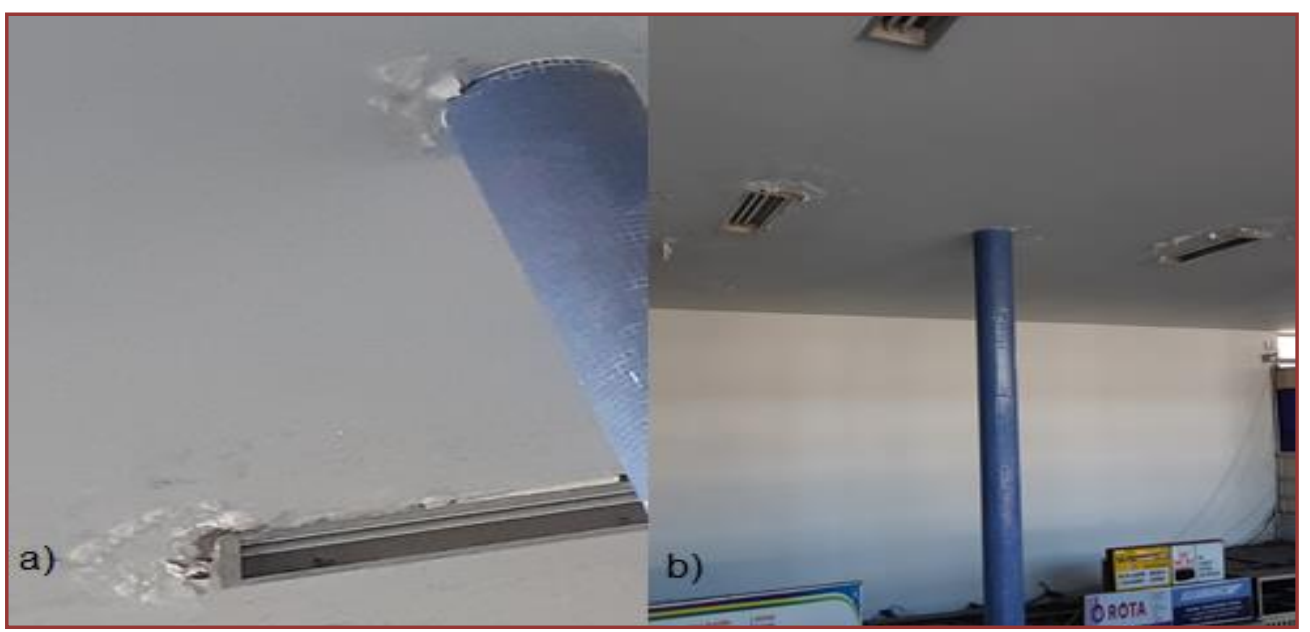

Fonte: Acervo Pessoal (2018)

O terceiro tipo de patologia mais encontrado na área superior da edificação foi a Lixiviação, tendo a ocorrência em dois pontos próximos. Foi observado este tipo de patologia na área lateral externa superior da edificação, a lixiviação é facilmente encontrada e visível devida sua aparência esbranquiçada, que geralmente se destaca e chama a atenção na estrutura. Esta aparência é decorrência da perca de componentes químicos, que acabam interferindo na resistência e na eficiência da estrutura num todo. Como identifica a Figura 19.

De acordo com Helene (1997), a lixiviação corresponde aos mecanismos que aceleram a deterioração do concreto armado, acontece através da ação de águas puras, carbônicas e ácidas que se dissolvem e conduzem os componentes hidratados da pasta de cimento. Sendo composta por uma exterioridade arenosa ou pelo aparecimento de agregados expostos sem o seu componente superficial. Consequentemente se observa também uma redução do $\mathrm{pH}$ do extrato aquoso dos poros superficiais do concreto e de seu componente estrutural com risco de despassivação da armadura.

Em número de ocorrências as Fissuras tiveram o mesmo número de ocorrências da Lixiviação. Foram observadas em locais distintos, como mostra a Figura 20, um deles localizado na laje da fachada, podendo ter surgido devido vários fatores, um desses motivadores pode ser proveniente do recalque do solo que é bastante evidente nesta área, a outra Fissura está localizada na lateral da edificação, possível de ser visualizada pela área externa.

Para Vitório (2003), as causas das fissuras nem sempre são facilmente descobertas, mas seu reconhecimento é de suma importância para a adoção dos procedimentos adequados de correção. Geralmente os casos de fissuração são provocados por tensões de tração e cisalhamento.

Figura 20: Fissura

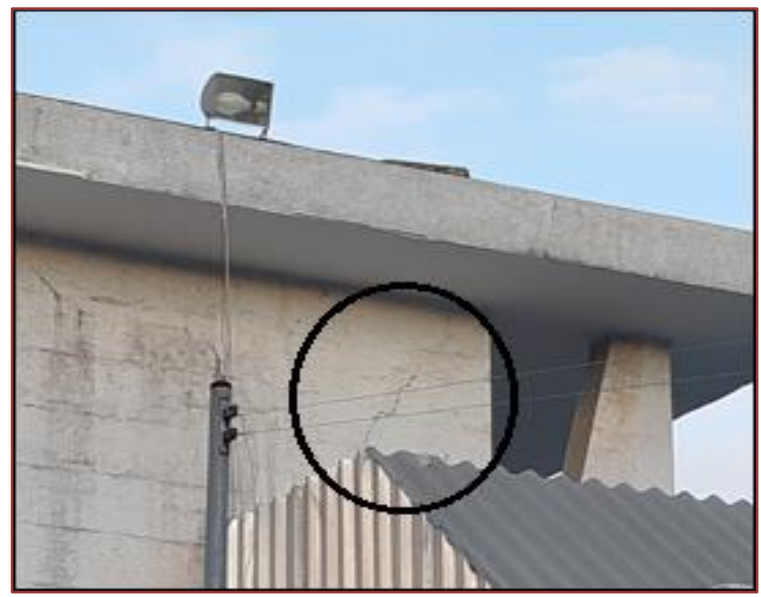

Fonte: Acervo Pessoal (2018) 
Com um único caso detectado, a penúltima Manifestação Patológica da área superior da edificação foi a Rachadura. De fácil percepção, pois a mesma se encontra de forma linear e contínua, atravessa toda a estrutura de um lado a outro. Este tipo de manifestação facilita o acesso de água da chuva na estrutura, podendo aumentar as chances de corrosão e o aparecimento de vegetação na edificação.

Certos defeitos exigem conhecimento global da edificação, Rachadura é uma abertura significativa que pode surgir na superfície de qualquer material sólido, proveniente de grande ruptura de sua massa, e cuja espessura varia de $1,00 \mathrm{~mm}$ até $1,5 \mathrm{~mm}$.

Assim como a Rachadura encontrada, a Presença de Vegetação só foi perceptível em um ponto da edificação. Esta localizada no WC dos Funcionários, A parede encontra-se quebrada, úmida, com encanação á mostra e com Vegetação saindo de sua estrutura. A presença de vegetação numa edificação é bastante preocupante, pois, pode ocasionar diversos tipos de influencias no desempenho estrutural como também o entupimento de suas tubulações.

Para Conceição (2011), a vegetação é um agente biológico que cresce em locais que encontra um substrato adequado ao seu crescimento, podem afetar a qualidade e integridade do produto armazenado. Os danos relacionados que elas causam estão ligados à própria edificação e ao seu redor. A vegetação não intencional se desenvolve devido à junção de matéria orgânica em reentrâncias da edificação, ocasionando danos à estrutura, desagregação no revestimento e fissuras que seguirão um caminho direto para a umidade.

\subsection{PANORAMA GERAL}

Na pesquisa visual realizada no Terminal Rodoviário Governador Luiz Garcia em procura de Manifestações Patológicas puderam-se detectar patologias de diversas origens e causas, qualquer que seja o número de ocorrências de uma determinada patologia não minimiza sua relevância, assim, antes de qualquer ação preventiva que possa ser tomada, deve-se avaliar a edificação num todo, minunciosamente, realizar testes para que se detecte a causa e a gravidade de determinada manifestação, avaliando uma maneira de corrigi-la. No caso do Terminal Rodoviário preocupa-se também com a preservação arquitetônica da estrutura. A Figura 23 em formato de gráfico demonstra um Panorama Geral da edificação.

Segundo Vitório (2003), diversas vezes, além da uma análise visual, faz-se necessário a realização de determinados ensaios designados a fornecer informações sobre as condições de resistência e de ruptura dos componentes da estrutura em questão vistoriada, além de um maior conhecimento sobre o solo de fundação do local.

Diversas vezes, além da avaliação visual, se faz necessário realizar determinados ensaios para fornecer informações direcionadas às condições de resistência e ruptura de componentes da estrutura vistoriada, além de maior conhecimento sobre o solo de fundação.

Figura 23: Panorama Geral

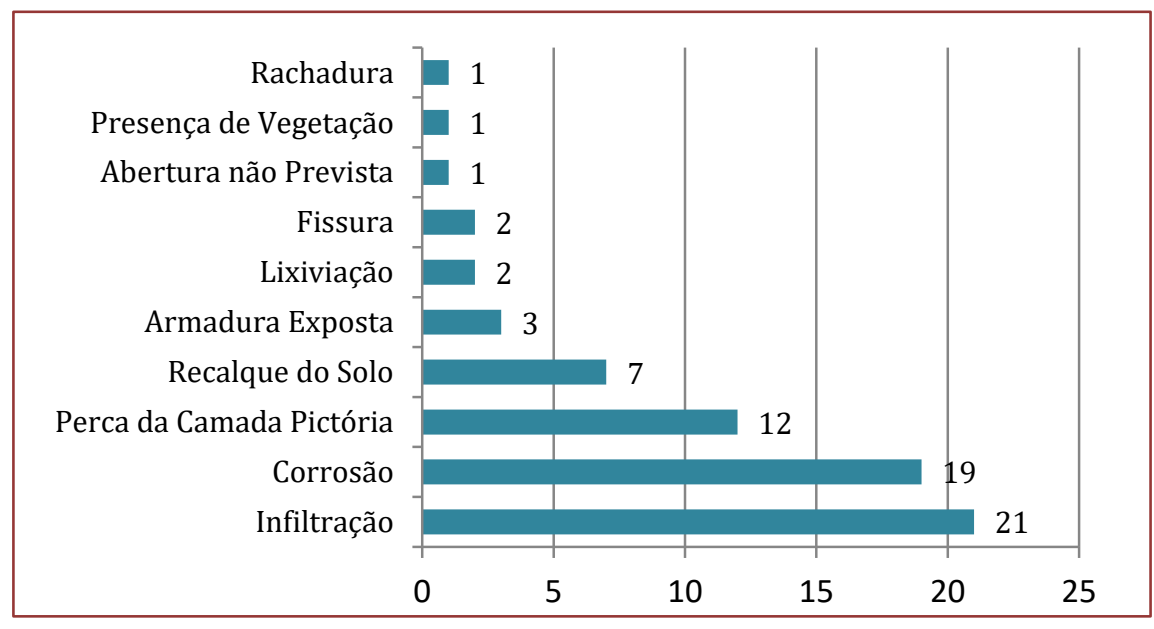

Fonte: Adaptação do Próprio autor, 2018 


\section{CONCLUSÃO}

Conclui-se que a situação atual das edificações situadas no Centro Histórico de Aracaju, bem como em grandes centros brasileiros, é altamente preocupante, demonstrando que o poder público não investe o suficiente em políticas públicas para a preservação e conservação desse tipo de edificação. Os resultados obtidos apontam para numerosas e graves Manifestações Patológicas encontradas no Terminal Rodoviário Governador Luiz Garcia decorrentes de poucos investimentos em sua preservação tanto arquitetônica quanto estrutural.

Toda edificação, independente de sua tipologia estrutural possui um determinado tempo de Vida Útil, e para que seja garantida sua eficiência, atitudes de preservação devem ser realizadas periodicamente. Quando não se tomam atitudes preventivas e conservantes, a estrutura sofre, seja por ações da natureza que surgem inesperadamente ou por ações humanas feitas sem um planejamento adequado.

o Terminal Rodoviário Governador Luiz Garcia necessita ser submetido em caráter de urgência a um processo de reforma e revitalização, desde sua fundação até sua cobertura. Ensaios patológicos devem ser realizados na estrutura num todo para que se tenha a situação exata em que o mesmo se encontra, para posteriormente se realizar os devidos reforços, da fundação, da estrutura, da sua armação, assim como ser feita uma nova cobertura, visando evitar a Infiltração, que é o maior problema da edificação no momento. Ações corretivas precisam ser realizadas, para garantir segurança e confiabilidade à edificação e consequentemente a seus usuários, preservando assim este grande monumento para o centro de Aracaju.

\section{REFERÊNCIAS}

[1] BURGESS, E. W. (2017). O crescimento da cidade: Uma introdução a um projeto de pesquisa. Sociedades Urbanas, Revista de Antropologia e Sociologia, 204.

[2] CAMPOS, L. E. (2006). Técnicas de Recuperação e Reforço Estrutural com Estruturas de Aço. p. 104

[3] CARMO, M. A. (2009). Estudo da Deterioração de Marquises de Concreto Armado nas Cidades de Uberlândia e Bambuí. p. 139.

[4] CARVALHO, D. M., TRINDADE, G. A., \& VELLOSO, T. R. (2011). Centro de Aracaju-SE: fixos e fluxos urbano-regionais. p. 8.

[5] CONCEIÇÃo, C. A. (2011). Avaliação de Manifestações Patológicas em Bases de Unidades Armazenadoras de Grãos da Fronteira Oeste. p. 88.

[6] DIAS, A. D. (2011). Avalição do desempenho térmico de coberturas metálicas utilizadas em edificações estruturadas em aço. p. 110.

[7] DUARTE, F. (2009). Planejamento Urbano. IBPEX.

[8] FONSECA, V., \& BESERRA, A. P. (2014). Crescimento urbano e mobilidade em Aracaju: 2009 a 2012. p. 10 .

[9] GUEDES, J., COSTA, A., ARÊDE, A., \& PAUPÉRIO, E. (2002). Reabilitação e Reforço de Estrutura Patrimônio Nacional. Ezperiência da FEUP, p. 11.

[10] HELENE, P. (1997). A Nova NBR 6118 E A VIDA ÚTIL DAS ESTRUTURAS DE CONCRETO . p. 43.

[11] IBGE. (2018). Instituto Brasileiro de Geografia e Estatística. Acesso em Maio de 2018, disponível em Séries Históricas e estatísticas $<$ https://seriesestatisticas.ibge.gov.br/series.aspx?no=10\&op $=0 \& v$ codigo $=C D 90 \& \mathrm{t}=$ populacao-presenteresidente $\% 20$ Popula $\% C 3 \% A 7 \%$ C3\%A3o\%20estimada:\%20IBGE,\%20Diretoria $\% 20 \mathrm{de} \% 20$ Pesquisas, $\% 2$ 0Coordena\%C3\%A7\%C3\%A30\%20de\%20Popula\%C3\%A7\%C3\%A30\%20e\%20Indicadores\%20Sociai>

[12] IBGE. (2018). Instituto Brasileiro de Geografia e Estatística. Acesso em Maio de 2018, disponível em Pesquisas Cidades $<$ https://cidades.ibge.gov.br/brasil/se/aracaju/pesquisa/23/27652?detalhes=true $>$

[13] MARICATO, E. (2000). Urbanismo na Periferia do Mundo Globalizado. Metrópoles Brasileiras, p. 13. 
[14] MARTINE, G., \& McGRANAHAN, G. (2010). A transição urbana brasileira: trajetória, deficuldades e lições aprendidas. In: R. Baeninger, População e Cidades, subsídios para o planejamento e para as políticas sociais (p. 304). Campinas: UNFPA; NEPO; UNICAMP.

[15] MENEZES, C. R., \& VASCONCELOS, J. F. (2011). O Estado de Sergipe: da urbanização à formação metropolitana. Revista Espaço Acadêmico, 8.

[16] MONTEIRo, L., AMORiM, B., SANTOS, M., FURTAdO, F., LinhARES, P., \& COElHO, F. (2013). Incidência de manifestações patologicas em prédios residenciais em Sobral - CE. p. 7.

[17] OLIVEIRA, D. F. (2013). Levantamento de causas de patologias na Construção Civil. p. 107.

[18] PINHEIRO, R. C., \& SANTOS, C. A. (2013). Evolução Urbana, Cultural e Turismo no Centro Urbano de Aracaju-SE. p. 22.

[19] SILVA, C. H. (2009). Espaço Público Político e Urbanidade. O caso do centro da cidade de Aracaju, p. 181.

[20] SILVA, E. D., \& NOGUEIRA, A. D. (2015). FUNDAMENTAÇÃO TEÓRICA PARA PROTEÇÃO DE EDIFICAÇÕES E/OU CONJUNTOS URBANOS. Estudo do tombamento de edificações dos bairros centrais de Aracaju/SE, p. 20.

[21] SILVA, L. K. (2011). Levantamento de Manifestações Patológicas em Estrutura de Concreto Armado no Estado do Ceará. p. 61.

[22] TINOCO, J. E. (2009). Mapa de Danos. Recomendações Básicas, p. 23.

[23] VITÓRIO, A. (2003). Fundamentos da Patologia das Estruturas nas Perícias de Engenharia. p. 58.

[24] VIANA, ÉRICA (3017). Macrodrenagem Sustentável: Avaliação do Escoamento Superficial Urbano no Município de Aracaju/SE. p. 66. 


\section{Capítulo 7}

Inspeção de espaços públicos urbanos localizados em região litorânea de Aracaju/SE acometidos por manifestações patológicas de corrosão

\section{Claryssa de Oliveira Barros \\ Ana Angélica dos Santos Faro}

Resumo: As áreas litorâneas e costeiras das cidades, geralmente têm característica de concentrar áreas sociais públicas de convívio, em virtude das belas paisagens naturais, no entanto, nessas faixas territoriais, o desgaste das estruturas causado por corrosão é muito grande, o que torna dificultosa a conservação das construções nesses locais. 0 presente trabalho tem por objetivo fazer uma análise dos processos de corrosão, que agem nas edificações dos espaços públicos urbanos, do município de Aracaju, em região litorânea, com influência do ambiente marinho costeiro, bem como a realização de manutenção por órgãos responsáveis para a conservação desses espaços. Para tal, este trabalho foi embasado em estudos de caso, onde foram feitas inspeções visuais e registros fotográficos da ocorrência da patologia citada, em 6 espaços públicos urbanos escolhidos para averiguação. Os resultados obtidos com a elaboração deste estudo mostram que dentre os locais escolhidos para análise, 2 deles se apresentaram conservados, por terem sido inaugurados a pouco tempo ou passado recentemente por reforma de revitalização, outros 2 se encontraram com patologia impregnada na estrutura e os 2 demais, apresentaram as formas de corrosão mais severas e intensas, que acabaram por ocasionar a interdição dos espaços, confirmando, que o ambiente no qual as estruturas estão inseridas somado a falta de manutenibilidade dos espaços públicos, influenciam no processo de corrosão atuantes nos locais analisados.

Palavras-chave: Corrosão. Espaços Públicos Urbanos. Manutenção. 


\section{INTRODUÇÃO}

Diante dessa situação, a existência de um programa apropriado de manutenção preventiva/corretiva, é um meio de garantir a durabilidade e desempenho das edificações, para que se cumpra a vida útil de projeto, e de assegurar a redução de custos com reparos.

Segundo Cascudo (1997), o fato de algumas das principais cidades do Brasil, estarem localizadas na costa do país, torna a ocorrência da corrosão, uma das principais manifestações patológicas. A incidência da grande quantidade de partículas viajantes na atmosfera, provenientes do mar, como é o caso dos íons cloreto, dão embasamento a essa apreensão.

No estado de Sergipe, a presença intensa da névoa salina é bastante preocupante, pois é considerada umas das mais destrutivas e severas do continente, e atua diretamente nas estruturas das edificações inseridas nos territórios costeiros.

No município de Aracaju, em sua região litorânea costeira, é possível encontrar espaços públicos urbanos que apresentam estado físico deplorável, com estrutura danificada e parte estética afetada, decorrente a falta de atenção necessária para a questão de manutenibilidade dos locais.

O objetivo central desse trabalho é analisar os processos corrosivos, atuantes nas edificações do espaço público urbano do município de Aracaju, mais especificamente em região litorânea, com influência do ambiente marinho costeiro. Os objetivos secundários visam mostrar a importância da manutenção das edificações para conservação de espaços públicos urbanos, inspecionar e analisar a integridade física de espaços públicos específicos e averiguar a atuação dos órgãos responsáveis por espaços públicos, quanto a conservação e manutenção destes.

A concretização do trabalho se deu a partir da observação, através de estudo de caso, da ação do processo corrosivo nos espaços públicos urbanos, e da proposição de intervenções e terapias para amenizar e/ou solucionar o problema patológico.

\section{METODOLOGIA}

Aracaju está situada na região nordeste do país, em zona litorânea, e é cortado pelos rios Sergipe e Poxim. Foi uma das primeiras capitais do Brasil que foram planejadas, usando como referência um tabuleiro de xadrez, com o intuito de desembocarem no Rio Sergipe. Os espaços utilizados no estudo, são as edificações dos espaços públicos urbanos localizados à margem do rio Sergipe em um perímetro de aproximadamente 7,9 km de extensão (CASO 1 - Mirante da praia treze de julho; CASO 2 - Espaço de convivência sombreado do calçadão da praia formosa; CASO 3 - Atracadouro da Ivo do Prado; CASO 4 - Ponte do Imperador Dom Pedro II; CASO 5 - Píer da 1 $1^{\text {a }}$ etapa da orla do bairro industrial; CASO 6 - $2^{\circ}$ Etapa da orla do bairro industrial, como apresentado na Figura 1).

A vistoria dos espaços públicos foi realizada "in loco" e embasada em análise visual. Nela foi estabelecida a ocorrência das patologias por meio da observação dos sintomas aparentes. Também foi utilizada como ferramenta de apoio na inspeção dos locais escolhidos, a aplicação de uma lista de verificações, que proporcionou maior dinamismo nos levantamentos das manifestações patológicas e informações em campo.

A elaboração da lista de verificação utilizada, foi baseada na Norma de Inspeção Predial Nacional - IBAPE NACIONAL (2012) e no método GUT - "Gravidade, Urgência e Tendência", que segundo Verzola, Marchiori e Aragon (2014), é um método de gerenciamento de risco criado por Kepner Tregoe, publicada em 1977 com o título "Análise de Problema e Tomada de Decisão". 0 método leva em consideração a gravidade (G), a Urgência (U) e a Tendência (T) dos casos verificados e classifica cada item inspecionado em sua gravidade, urgência e tendência.

Também foi realizado um levantamento histórico evolutivo da situação das edificações, desde a utilização dos espaços públicos urbanos até as suas manutenções, através da anamnese, que somado ao auxílio dos órgãos públicos responsáveis, Defesa Civil Municipal e Estadual; Empresa Municipal de Obras e Urbanização (EMURB); Empresa Municipal de Serviços Urbanos (EMSURB) e Companhia Estadual de Habitação e Obras Públicas (CEHOP), foi possível fazer coletas de informações orais e obter informações formalizadas importantes, das áreas em análise. 
Figura 1 - Espaços públicos analisados: a) Mirante da praia treze de julho; b) Espaço de convivência sombreado do calçadão da praia formosa; c) Atracadouro da Ivo do Prado; d) Ponte do Imperador Dom Pedro II; e) Píer da $1^{\underline{a}}$ etapa da orla do bairro industrial; f) $2^{\circ}$ Etapa da orla do bairro industrial.
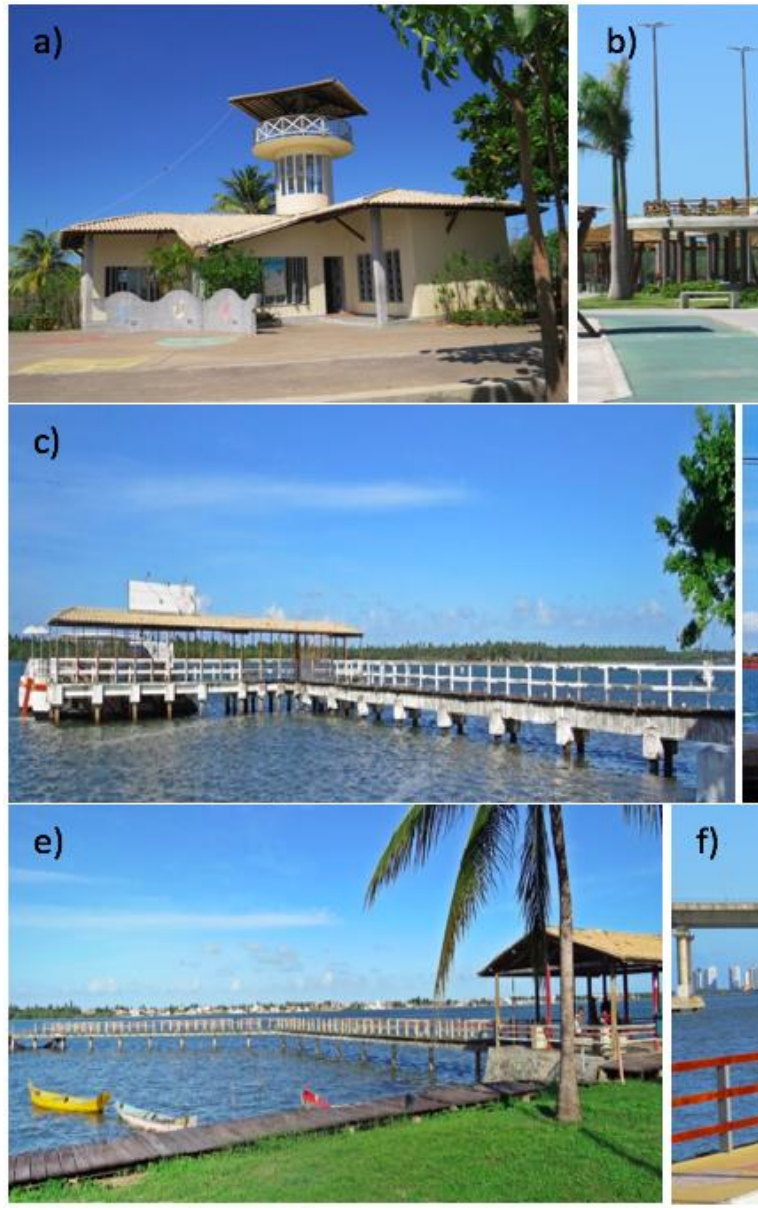

f)
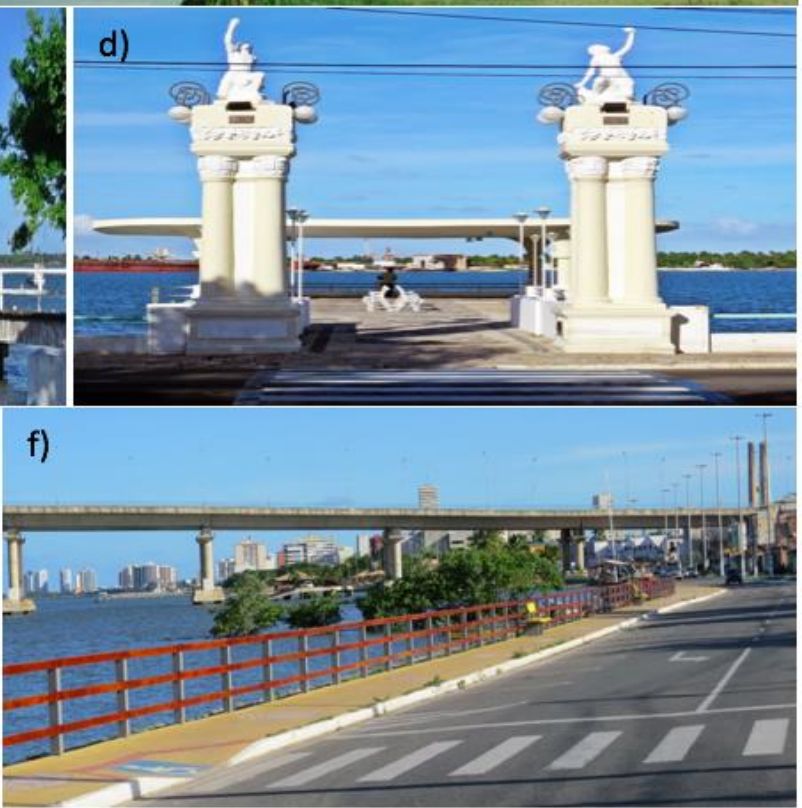

Fonte: Acervo do autor (2017)

\section{RESULTADOS E DISCUSSÃO}

\subsection{CASO 1 - MIRANTE DA PRAIA TREZE DE JULHO}

Situado no Bairro Treze de Julho, o Mirante foi construído em setembro de 1998, e passou a ser um ponto turístico da cidade de Aracaju, pelo fato de possibilitar uma graciosa vista do Rio Sergipe, calçadão da 13 de Julho, manguezal, Praia dos Artistas e Centro Histórico.

Considera-se que ele está localizado em zona de atmosfera marinha, onde nessa região sofre a ação da névoa salina, e recebe um valor relevante de sais, que são motivadores pelas deposições salinas na superfície da estrutura.

A parte estrutural, constituída por concreto armado, não apresenta aparentemente nenhum dano relevante nem proveniente de processo corrosivo. Porém, algumas peças de suas estruturas metálicas apresentam processo corrosivo já instalado.

A escada, parte integrante da estrutura metálica do local, encontra-se atacada pela manifestação da corrosão, visto que seus degraus apresentam superfície com aspecto deteriorado, com volume aumentado, demonstrando o descascamento superficial, decorrente a expansão do material.

Assim como na escada, na base do corrimão também foram apresentadas características de corrosão. A partir de Coelho (2015), essa corrosão pode ser classificada como por esfoliação, por ela possuir característica principal de expansão de volume, e por causar a segregação das camadas do material comprometido pela corrosão, formando aspecto de placas paralelas. 
Pôde ser notado também a ocorrência da corrosão, que com base em Gentil (1996), pode ser indicada como do tipo empolamento por hidrogênio, que ao adentrar o material, expande-se e exerce pressão que resulta na formação de pequenas bolhas, que ficaram aparentes no tubo eixo da escada.

Como afirma Magnan (2011), o emprego de material de pintura incompatível com a situação do ambiente agressivo e ineficiente na proteção contra agentes promotores da corrosão, pode ter motivado a manifestação patológica a se instalar.

Silva (2009) afirma também que, a proteção proferida as superfícies metálicas pela pintura, precisa sofrer manutenção. Alguns dos fatores que causam falhas e deterioração da pintura que age protegendo o metal, são: os danos ocasionados de forma mecânica, a limpeza inadequada antes da aplicação da tinta na superfície e a aplicação feita de maneira incorreta.

Na parte superior do mirante, foram vistas mais atuações de ação corrosiva. Pôde-se ver a atuação da corrosão do tipo em placa na peça base do guarda corpo do mirante, responsável pela fixação da estrutura na laje. Em concordância com o que Coelho (2015) descreve, as características principais de deterioração dessas peças encontradas na peça, foi a formação de sulcos por entre as placas formadas que se desprenderam da superfície do material metálico.

Análises mais aprofundadas da situação patológica de corrosão, devem ser feitas, para se ter uma maior dimensão do quanto as peças metálicas estão comprometidas.

\subsection{CASO 2 - ESPAÇO DE CONVIVÊNCIA SOMBREADO DO CALÇADÃO DA PRAIA FORMOSA}

Localizado no Bairro Treze de Julho, o Calçadão da Praia Formosa foi inaugurado em 15 de julho de 2016, considerado como uma extensão do calçadão da 13 de Julho, possui uma área de 200 mil metros quadrados e atrativos para lazer e prática esportiva.

A edificação está à margem do encontro do rio com o mar, porém não está em contato direto com a superfície de água. 0 espaço público está situado em zona atmosférica marinha.

Apesar de ser uma edificação considerada nova, levando em conta sua data de inauguração para uso dos cidadãos da cidade, já apresenta diversos aspectos de prováveis patologias. Dentre as patologias que salientam aparecer, está o processo de corrosão da armadura, que pode ser evidenciado em várias partes do local analisado.

Embaixo da escada, que dá acesso a parte superior do espaço de convivência sombreado foi verificado que uma parte da armadura da escada ficou exposta, a falta do cobrimento adequado a armadura, provavelmente foi causado pela ausência de espaçadores ou por falha de execução no momento de colocálos, os quais evitariam o contato da armadura com a fôrma de concretagem.

Helene (1986) comenta que ao se utilizar e colocar espaçador ou fixador de formas, deve-se respeitar a distância da camada que será concretada, porque o acomodamento do plástico, em relação ao concreto, acha o dispositivo e forma sob ele espaços vagos, que permitem a entrada de agente agressivos que atuam na armadura.

Essa falha implica na falta do cobrimento de concreto adequado, para proteção da armadura, o que facilita de forma drástica a degradação da sua película passivadora, incitando o início de corrosão, que provavelmente causará, em um pequeno espaço de tempo, a diminuição da seção desta armadura de aço, e consoante Lapa (2008), consequentemente levará ao seu rompimento.

Outro ponto que chama atenção na estrutura é a existência de materiais "embutidos" na laje já concretada, como é o caso do resto de forma de madeira, e de isopor utilizado nas juntas de dilatação nas emendas da laje. Essas falhas também podem ser atribuídas a fase de execução da obra, onde não retiraram corretamente as fôrmas de madeira utilizadas na concretagem e nem fizeram o cobrimento correto das brechas preenchida com o isopor nas emendas de laje.

As peças de madeira e de isopor, que quando expostos a névoa salina, por terem uma resistência menor que a do concreto da edificação, irão se deteriorar, deixando vazios e brechas no concreto. Desse modo, se tornarão a porta de entrada dos agentes agressivos do meio externo, presentes na atmosfera marinha, como afirma Helene (1986), ao dizer que toda ação que leva ao fenômeno de permeabilidade do concreto, intensifica a difusão de fatores agressivos, que prejudica a proteção do aço de armadura.

Além dos restos de fôrma de madeira e de isopor, que facilitam a entrada de agentes externos que atacam a estrutura, ao longo da superfície inferior da laje, do espaço de convivência sombreado, pode-se 
encontrar a ocorrência de vazios no concreto, por meio das "bicheiras", os vazios de concretagem, que segundo Figuerola (2006) são causadas geralmente pelo excesso de agregado graúdo combinado a um concreto fluido, pela concentração de barras no mesmo local que dificulta a vibração e espalhamento do concreto, por concreto com valor de slump baixo utilizado em peça esbelta, pela execução inadequadas de fôrmas, entre outros.

A parte superior da estrutura possui canteiros com jardim, e pôde-se evidenciar a existência de pontos de drenagem na laje, para o escoamento das águas pluviais. Nessa situação, foi verificada a ocorrência de erro de projeto referente a localização de alguns desses pontos de drenagem, visto que os mesmos estão posicionados de maneira que as águas que escoam por esses artifícios, caem sobre a estrutura da rampa, na qual não foi realizado nenhum tipo de preparação para receber o escoamento da água. Observa-se que as águas que escoam na rampa, provocaram uma visível infiltração na peça de concreto armado, o que consequentemente implica no envelhecimento do concreto, levando os compostos internos do concreto à tona em sua superfície.

A consequência dessa ação é o surgimento de manchas brancas na superfície da estrutura, originadas de depósito salino, característica de carbonatação, que consoante Gentil (2003), vai favorecer a velocidade de surgimento corrosão, por causa da diferença do valor de pH e aeração.

Em outro ponto da estrutura de concreto armado, também notoriamente prejudicado pela presença de umidade, existe o risco de uma complicação maior quanto a integridade da estrutura. O local está visivelmente afetado por manchas esbranquiçadas de depósitos salinos, eflorescência, originadas pela umidade presente na laje de cobertura, que possivelmente também poderá acarretar em um início de corrosão. Além desse problema com a umidade, pode-se identificar a presença de resto de forma de madeira bem próximo, o que sugere uma porta de entrada para agentes externos, que podem aumentar o dano causado pela patologia.

Durante a inspeção visual, foram observadas situações, que aparentemente mostram ser um início de deterioração por corrosão em torno do cordão de solda e manchas nos guarda-corpos por ferrugem, tanto nos corrimãos da rampa, quanto nos escada.

Esse tipo de corrosão acontece, conforme Gentil (1996) de forma intergranular nas juntas de solda de metais, geralmente em aço inoxidável, possuindo como principal característica a perda progressiva de suas propriedades mecânicas, caso não receba reparos a tempo, a corrosão pode progredir e mais para frente poderá levar a um acidente por propiciar a ruptura do material, quando forem requisitados por esforços mecânicos. Bertolini (2010), fala que por vezes, os cloretos agem modificando visualmente a superfície de um metal, que no caso observado foi a perda parcial de brilho e acúmulo de camadas de ferrugem, que formam manchas.

Outro problema observado na inspeção feita, foi em relação a escolha do tipo de material utilizado na obra, que deveria ter sido escolhido com base na situação a que as peças seriam submetidas. Podemos ver a ocorrência de uma corrosão do tipo galvânica. A porca e a arruela, por estarem em contato direto com o material da chapa de fixação do guarda corpo de madeira e por ter qualidade inferior de material, é preferencialmente corroída, de forma mais acelerada, pelo metal de qualidade superior. De acordo com Pannoni (2009), essa corrosão se dá quando ambos metais estão na presença de contato elétrico e de um eletrólito, que nesse caso é a atmosfera marinha.

Um ponto verificado, de forma positiva, na parte inferior do espaço de convivência sombreado, foi a proteção dos pilares que foram pintados. A ação de pintar os pilares, conforme Lapa (2008), faz com que a tinta preencha parte dos vazios existentes na superfície do concreto, diminuindo assim a entrada de agentes externos agressivos e consequentemente diminuindo consideravelmente o início de um processo de corrosão, proveniente de carbonatação ou ataque por íons cloreto nessas estruturas, lembrando que as pinturas devem receber manutenção, por terem vida útil reduzida.

\subsection{CASO 3 - ATRACADOURO DA IVO DO PRADO}

Situado na Av. Ivo do Prado, o atracadouro também conhecido como o "Atracadouro da Crase" ou "Atracadouro do Largo do Rádio Amador", que fazia referência a um antigo restaurante, Crase.

Construído em 1978, possuía apenas a parte da estrutura que avança o Rio. No ano de 2000 sofreu uma ampliação, recebendo uma nova parte em posição concorrente a já existente, a qual passou a servir por anos a destinação de embarque/desembarque de catamarãs em passeios turísticos pelo Rio Sergipe. 
Em inspeção feita no local, foi visto que a estrutura está inserida em ambiente com bastante exposição à névoa salina, e recebe a influência direta da variação de maré e de seus respingos, portanto está classificada em um ambiente de agressividade muito forte, de nível IV, conforme ABNT NBR 6118:2014. Consequentemente seu risco de deterioração é considerado muito elevado.

Pôde-se constatar degradação do guarda corpo de concreto armado, por toda a extensão de sua passarela. Diversos pontos mostram a ação da corrosão pela presença da salinidade atmosférica. Por apresentarem fissuração e destacamento de concreto, demonstra um avançado nível da patologia.

0 ataque corrosivo a armadura do concreto está evidente, assim como a degradação do concreto que o reveste. A causa do destacamento do revestimento de concreto da armadura, é explicado por Cascudo (1997), que se dá pelo motivo da armadura aumentar de volume quando ocorre a corrosão no material, com esse aumento tensões são geradas e provocam fissuras, as quais são brechas de entrada de agentes agressivos do meio externo, e leva até o destacamento do concreto de cobertura da armadura. Segundo Lapa (2008), a redução da seção das barras de aço, por conta da corrosão, minimiza a capacidade estrutural da estrutura de concreto do atracadouro.

A redução de seção das barras de aço, chegou a um estado tão crítico, que causou o rompimento de parte do guardo corpo, do lado direto da passarela.

Os pilares de fundação possuem uma parte submersa e outra que sofre ação de variação de maré e seus respingos. A parte dos pilares em contato direto com a água, são propícios a ter saturação do concreto, restringindo a entrada de oxigênio na região de armadura, seu principal agente oxidante, dessa maneira controlando a velocidade de corrosão dessa parte em contato com a água.

A parte influenciada pela variação de maré é a mais prejudicada pelo ataque das águas salobras e ricas em sais, que favorecem a penetração de íons cloreto no concreto nesse trecho. Com o ataque dos íons cloreto favorecido, a corrosão acontece de forma desimpedida, prejudicando a aderência entre o aço e o concreto, causando aumento da armadura, que segundo Cascudo (1997), faz aparecer fissuras, que aumentam a entrada de agente agressivos que se somam ao prejuízo causado na armadura. Assim é gerado por conseguinte, o descolamento de concreto que age como revestimento.

Assim como os pilares de fundação, as vigas e os blocos também sofrem nítida degradação.

Todas peças estruturais recebem influência da atmosfera marinha, algumas são atingidas por respingos de maré e sofrem variação de nível de maré, todos esses fatores as levam a apresentar características de corrosão por elevada concentração de teor de íons cloreto. Recebem também, por estarem situadas em uma área de localização de avenida com grande fluxo de automóveis, a influência de alta concentração de gases, como por exemplo o $\mathrm{CO} 2$, que as conferem características de deterioração por corrosão, incitada pelo processo de carbonatação.

Brasil (2010), explicita que em presença da carbonatação, os concretos com alta taxa de cloretos, podem ter uma parte destes liberados, fato que acaba por intensificar a velocidade da corrosão. Caso esse processo aconteça ao mesmo tempo que a variação de nível de maré, onde ocorre o ciclo de molhagem e secagem da estrutura, a velocidade da corrosão é acelerada consideravelmente.

0 atracadouro, que atualmente apresenta tantos problemas e deteriorações, já serviu de ponto de embarque/desembarque, funcionando normalmente até o dia 8 de Julho de 2016. Porém, o debilitado estado de sua edificação, o fez ser interditado, pela Setesp (Secretaria de Estado do Turismo e do Esporte), após uma fiscalização técnica e elaboração de laudo por parte da CEHOP (Companhia Estadual de Habitação e Obras Públicas), que apurou a ocorrência de problemas na estrutura, confirmando a vistoria prévia pela Setesp, no dia 11 de Julho de 2016.

Em Junho de 2006, o engenheiro Artur Luiz de Melo, da gerência de projetos da Companhia Estadual de Habitação e Obras Públicas - CEHOP, já havia elaborado um parecer técnico, alertando sobre o estágio de acentuada degradação, que o atracadouro apresentava, sugerindo por meio do parecer que fosse elaborado projeto de recuperação da estrutura, com base em investigações mais aprofundadas, evitando que o risco da estrutura evoluísse e que o aumento para a revitalização aumentasse.

Ainda a pedido do Ministério Público Estadual, 5a promotoria de justiça dos direitos do cidadão especializada na fiscalização dos serviços de relevância pública, no dia 11 de Julho de 2016, foi realizado um relatório de vistoria, pela Secretaria Municipal de Defesa Social, Coordenadoria Municipal de Defesa Civil- COMDEC, pelo motivo do estado de conservação e segurança do atracadouro e encaminhado ao responsável pelo espaço público, o Governo do Estado de Sergipe. 
De acordo com as análises feitas no relatório de vistoria de $\mathrm{n}^{\circ} 104 / 2016$ da COMDEC, perante as patologias e avançado estado de deterioração da estrutura, causados por exposição a intempéries, agentes agressivos, e a falta de manutenção, foi orientado que o órgão responsável pela prevenção e segurança do Espaço Público agisse com intervenção imediata, a fim de assegurar a integridade física dos usuários e evitar maiores danos materiais e um possível colapso.

Para a revitalização da estrutura do atracadouro e fazê-lo voltar a suas atividades rotineiras, por se tratar de problemas patológicos que interferem na parte estrutural, seriam necessários a elaboração de projeto específico de recuperação, embasado em análises mais aprofundadas com base em ensaios do teor de cloretos, grau de carbonatação, determinação de capacidade mecânica dos componentes mais afetados, e projetos estruturais de estruturas como a do guardo-corpo desabado, que não tem mais capacidade de recuperação.

Contudo, até o dia 7 de Maio de 2017, data de realização das análises visuais, o atracadouro encontrava-se interditado e com estado de deterioração mais crítico.

\subsection{CASO 4 - PONTE DO IMPERADOR DOM PEDRO II}

Construída no ano de 1860, a Ponte do Imperador Dom Pedro II, tinha a função de receber a comitiva real na cidade de Aracaju. Desde então, a edificação passou por diversas reformas e modificações. Em 1904, foi reformada, deixando de ser de madeira e passando a ser de outros materiais, como metal e vidros vindos da Inglaterra, e passou a possuir um portal medieval de castelo. Em 1920, foi reformada e compôs a fachada, com duas esculturas de índios, acima de dois torreões de alvenaria, como se apresenta nos dias atuais.

Ao adentrar no ambiente interno da ponte e vistoriar a edificação, percebeu-se que aparentemente a edificação está conservada, porém foram vistos alguns indícios patológicos, apesar da curta distância do tempo da última reforma.

No caso dos guarda-corpos e corrimãos, eles apresentam manchas em sua superfície, evidenciadas pela perda parcial do brilho e deposição de camada de ferrugem incrustada. Nem sempre essas manchas são consideradas como corrosão no aço, por serem superficiais e serem causadas, provavelmente, por contaminação de pequenas gotículas de água ou resíduos. Mas, por outro lado, se presume que pode ser indício de início de corrosão por ação de cloretos, que segundo Bertolini (2010), esses cloretos têm característica de transmutar a parte visual da superfície do metal.

Pôde-se verificar, que um dano ocasionado, suspeitando-se pelo formato do destacamento do concreto, por certo tipo de choque mecânico, que retirou parte do concreto que reveste a armadura do patamar da escada e do degrau da escada, que dão acesso ao Rio Sergipe, causando um início de processo corrosivo das armaduras que ficaram expostas e desprotegidas dos agentes externos presentes no ambiente em que se encontram.

Em relação a conservação da estrutura da edificação, foram observados pontos positivos, como a impermeabilização feita nos pilares de fundação e parte inferior do vão central da ponte, que ficam em contato direto com a variação e respingos de maré, e pintura, de algumas parte da estrutura, que mantém o bom estado de conservação e aumentam a durabilidade dos seus materiais.

Lapa (2008), diz que as estruturas de concreto armado, que se localização na linha de variação de maré, expostos a ação do ciclo de molhagem e secagem, são muito mais atacadas, de forma ríspida, do que as partes que ficam submersas. Com isso, a impermeabilização se faz necessária e importante nesse processo.

É notável a ação de vandalismo, na edificação do espaço público urbano analisada, representada na forma de pichação, fato que contribui para a poluição visual e aspecto de desordem, que também acaba contribuindo na degradação e má conservação das estruturas.

A integridade física dos postes de iluminação é visivelmente notada, mostrando a importância da pintura, que segundo Freire(2009), forma uma barreira impenetrável que protege a superfície do aço, exposta, por meio de tintas, esmaltes e vernizes. 


\subsection{CASO 5 - PÍER DA $1^{\circ}$ ETAPA DA ORLA DO BAIRRO INDUSTRIAL}

Inaugurada em 19 de Dezembro de 2003, a primeira etapa da Orla do Bairro Industrial, foi construída com estrutura para atender a comunidade e visitantes. Possui inseridos em sua extensão, restaurantes e lanchonetes com um menu que corteja a nossa culinária; parque infantil, para distração dos pequenos cidadãos; ciclovia e quadra, para prática de esportes; centro de artesanato, que expõe os mais belos trabalhos de artesãos da terra; banca de revistas; disponibiliza estacionamento e possui píer, que serve para contemplar as belezas do Rio Sergipe.

Ao lado do Restaurante do Sapatão, está localizado o píer, que fica sobre o Rio Sergipe. Muito frequentado por turistas, sua beleza acabou sendo ofuscada por riscos aos usuários e problemas estruturais muito notáveis.

Na vistoria realizada no local, foi verificado que a estrutura está inserida em um ambiente que recebe a influência direta da variação e respingos de maré, em parte de sua estrutura, e a outra parte acima do nível da maré recebe a influência degradante da atmosfera costeira.

Ficaram evidentes os riscos aos usuários, ao observar o estado em que se encontram os guarda-corpos da passarela do píer. Os pilaretes de concreto armado, no qual são presas as peças de madeira, possuem armaduras expostas, que ficam à mercê do ataque de agentes externos.

0 processo de corrosão já vem acontecendo, desde antes de sua inauguração. Em registros consultados que datam outubro de 2003, verificou-se que o píer, recebeu os últimos ajustes para a inauguração da $1^{\circ}$ etapa da Orlinha. Nesse mesmo registro, pode-se perceber que o produto do processo corrosivo, já era evidenciado, na forma de manchas de escorrimento com coloração característica, vermelho-marromacastanhada, e a porosidade do concreto dos pilaretes, que como Cascudo (1997) afirma, o fator água/cimento influencia diretamente na qualidade e porosidade do concreto. Quanto menor o fator água/cimento, menor são as chances da difusão de cloretos, dióxido de carbono e oxigênio no concreto.

A patologia, com o passar do tempo, continuou em evidência, por meio das manchas de escorrimento com coloração característica de corrosão, mesmo com a existência de manutenções, a qual foi feita pela EMURB, no ano de 2007.

Á medida que o processo corrosivo procede, por causa do rompimento da película passivadora, Lapa (2008) afirma, que os óxidos expansivos, produtos de corrosão, vão se instalando na superfície da armadura de aço, consequentemente o volume do aço se expande, causando maiores tensões ao seu redor e gerando fissuras, essas que são verdadeiras brechas para entrada de agentes agressivos e a aceleração do processo corrosivo. Foram encontradas fissuras nos pilaretes de concreto, da passarela do píer, na viga da escada que dá acesso ao Rio Sergipe e nos pilares de fundação. As fissuras nessas áreas se tornam mais danosas ainda, por estarem em uma área de influência direta de variação de nível de maré.

Foi evidenciado o estado da viga localizada abaixo do assoalho de madeira da passarela do píer. Nela podese ver a presença de fissuração na direção longitudinal da armadura e processo de corrosão instalado, caracterizado pela mancha de coloração característica.

Foi notado um processo de deterioração bastante agravado em vários pontos de concreto armado, assim como também nas peças de madeiras do guarda-corpos e assoalho, que além de degradadas e destruídas em certos pontos, em outros lugares apresentaram-se remendadas de forma inadequadas.

Atendendo o ofício $\mathrm{n}^{\circ}$ 854/2016, sobre a requisição de vistoria na passarela de Madeira da Orlinha do Bairro Industrial, com referência no Inquérito Civil $n^{\circ} 14.16 .01 .0073$, a pedido do Ministério Público Estadual, 5 a promotoria de justiça dos direitos do cidadão especializada na fiscalização dos serviços de relevância pública, no dia 29 de Maio de 2016, foi realizado um relatório de vistoria, pela Secretaria Municipal de Defesa Social, Coordenadoria Municipal de Defesa Civil- COMDEC, pelo motivo do estado de conservação e segurança do atracadouro e encaminhado ao responsável pelo espaço público, a EMURB.

De acordo com as análises feitas no relatório de vistoria de ${ }^{\circ}$ 65/2016 da COMDEC, a edificação foi interditada, perante a análise das patologias e avançado estado de deterioração da estrutura, causados por exposição a intempéries, agentes agressivos, e a falta de manutenção. Foi orientado que o órgão responsável pela prevenção e segurança do Espaço Público agisse com intervenção imediata, a fim de assegurar a integridade física dos usuários e evitar maiores danos materiais e um possível colapso.

Para que o píer da $1^{\circ}$ etapa da Orla do bairro Industrial possa ser desinterditado e o espaço público liberado para uso, já que os problemas patológicos levaram a danos mais consideráveis a parte estrutural, a estrutura deve passar por análises mais específicas e detalhadas, efetuadas por profissional habilitado 
na área e com conhecimento do caso, além de ter auxílio de equipamentos e ferramentas para realização de ensaios que comprovem a causa das patologias e capacidade mecânica estrutural. Com base nos dados e resultados obtidos deve ser elaborado projetos de execução para a revitalização.

No entanto, até o dia 7 de maio de 2017, data de realização das análises visuais, o píer e sua passarela de madeira ainda encontravam-se interditados e com estado de deterioração ainda mais críticos.

\subsection{CASO 6 - $2^{\circ}$ ETAPA DA ORLA DO BAIRRO INDUSTRIAL}

Inaugurada no dia 18 de março de 2017, a segunda etapa da Orla do Bairro Industrial, possui 400 metros de extensão, e é considerada um prolongamento da primeira etapa da Orla do Bairro Industrial.

Por ter sido inaugurada recentemente essa etapa da Orla do Bairro Industrial, diferentemente da primeira etapa, não demonstra ao longo de sua extensão problemas aparentes relacionados a estrutura nem estética. Os pilaretes de concreto armado, que constituem os guarda-corpos, juntamente com as peças de madeira, encontram-se em um estado de boa conservação estrutural e estética.

Aparentemente, diferente do que foi observado na $1^{\circ}$ etapa da Orlinha, a alta porosidade do concreto não está evidente nos pilaretes, onde o guarda-corpo de madeira está fixado. A pintura íntegra apresentada, conforme Lapa (2008), ajuda na proteção contra prováveis processos de corrosão.

Foi observado um aparente desgaste na superfície, das peças de madeira do guarda-corpo, pintado com verniz . Porém esse fato não implica em maiores prejuízos ao material, caso a repintura seja executada em próximas manutenções preventivas.

\subsection{ANÁLISES E SOLUÇõES}

Com base na análise visual e aplicação da lista de verificação, foi possível perceber, que quase todos os casos observados, possuem anomalias e falhas do tipo endógena, originada na fase de projeto, escolha de materiais e execução, e do tipo Natural, originada por ações da natureza, previsíveis ou imprevisíveis. Com exceção do Caso 4, que no lugar das falhas do tipo endógena, possui do tipo exógena, originada por fatores externos a edificação, causadas por pichação de terceiros, e do Caso 6, por apenas possuir do tipo Natural. Corroborando com Gomes (2016) quando comenta que a maioria das patologias encontradas são provenientes dos erros de projeto, dos materiais de qualidade baixa, da utilização inadequada, da execução errônea do serviço e da péssima execução de serviços, por mão de obra sem qualificação.

Ainda fazendo uso da lista de verificação, a qual foi embasada no método de GUT, que de acordo com Fáveri e Silva (2016), lida com as variáveis de gravidade, urgência e tendência, e é encarregado em dar respaldo as ações a serem tomadas, foi verificado que em relação a gravidade da edificação, os casos 1 e 2, possuem Gravidade da edificação considerada pouco grave, sem riscos aos usuários, com incômodos estéticos, caracterizados pelas manchas e falta de pintura, e reparos de manutenção planejada, necessários para recuperação; Urgência tida como baixa, com indício de incidente futuro, que precisa de intervenção programada, e possui Tendência avaliada como média, com incidente previsto para breve, pois a segurança começa a ser comprometida com a falta de conservação e manutenção do guarda-corpo, intervenção em curto prazo, com prazo para intervenção: 0 mais cedo possível, para evitar maiores prejuízos e evolução das patologias encontradas.

Nos casos 4 e 6, a gravidade da edificações são consideradas sem gravidade, com nenhum risco aos usuários, e as edificações; suas urgências e tendências não têm nenhuma consideração, com incidente imprevisto, com indicação de necessária manutenção programada. Devem receber intervenção, mas sem pressa no prazo de execução.

Já nos casos 3 e 5, em relação a gravidade das edificações, ela é considerada extremamente grave, tendo risco de colapso das estruturas, perda excessiva do desempenho e funcionalidade; suas urgências são consideradas de emergência, com necessidade de intervenções imediatas, e a tendência é dada como total, onde as intervenções das edificações devem ser imediatas, confirmando assim a atitude tomada pelos órgãos que as interditaram.

As soluções para os problemas encontrados, durante a inspeção visual, nos 6 espaços públicos urbanos estudados, devem ter como base análises científicas profundas e técnicas, fundamentadas em ensaios de laboratório e no local, para se definir qual conduta será seguida e qual escolha será feita, como alternativas de intervenção mais apropriada. 
Baseado nas inspeções e análises visuais, feitas nos espaços públicos escolhidos para desenvolvimento deste trabalho, e nos referenciais bibliográficos consultados, pode-se sugerir algumas intervenções para os problemas encontrados nos 6 casos.

No Caso 1, em relação a corrosão encontrada nos degraus e corrimão da escada e na base do guarda corpo superior, do mirante, sugere-se que pode ser dado um tratamento segundo Freire (2009), realizando uma limpeza superficial na estrutura metálica, através de escovamento ou jateamento abrasivo com areia, que remove as escamas de laminação, produtos do processo corrosivo, óxidos e partículas estranhas que possam existir. Depois, remove-se com auxílio de aspirador de pó, ar comprimido seco ou escova limpa, os resíduos provenientes da limpeza da superfície, e logo em seguida faz-se a cobertura com primer e uma camada intermediária de tinta e outra final, a fim de proteger e dar acabamento estético a peça.

Além dos procedimentos de recuperação das peças, no caso da peça base do guarda corpo do mirante, deve-se fazer uma verificação do desempenho dos parafusos de fixação. Caso eles não estejam atendendo as solicitações, devem ser substituídos, a fim de garantir a segurança da estrutura.

No Caso 2, para a armadura exposta, abaixo da escada, deve ser dada a devida atenção e sua área de seção deve ser verificada, de acordo com Souza e Ripper (1998), caso a perda de sua seção tenha atingido 15\% ou mais do valor de sua bitola, deverá ser substituída. Deve também, receber cobrimento adequado, de acordo com a Norma ABNT NB 6118:2014, a fim de garantir sua durabilidade e desempenho.

Em relação ao isopor exposto nas juntas de dilatação e emenda das lajes, o manual da Denver sugere, que se deve regularizar as bordas das emendas das juntas com argamassa de reparo, e após seu tempo de secagem, deve-se aplicar no seu encontro, um selante a base de poliuretano, que atuará na proteção do isopor e é ideal para manter a elasticidade, necessária nas juntas de dilatação, e se ter uma vedação resistente e durável.

Para a situação dos restos de madeira, que se encontram concretadas na laje, devem ser tratadas da mesma maneira que a situação das bicheiras de concretagem, encontradas na parte inferior da laje. Figuerola (2006), apresenta em seu trabalho, através de Paulo Fernando Araújo da Silva, que se deve delimitar a área que será reparada, retirar o concreto localizado na zona de reparo com ponteiro e martelo, até que se obtenha apenas o concreto homogêneo. Após a limpeza, estando lavado e saturado, o local deve ser preenchido em sua totalidade com material compatível com a elasticidade do concreto existente e ter como base o cimento, garantindo assim que a deformação do material de reparo seja semelhante ao existente no local.

Nos locais onde os pontos de drenagem desembocam água na rampa, com finalidade de realizar reparo, deve-se retirar a superfície danificada pela infiltração, reparar com argamassa de reparo e aplicar primer, manta líquida ou resinas impermeabilizantes, para impermeabilizar e proteger o concreto das infiltrações. Outra sugestão para a questão dos pontos de drenagem, seria a mudança de locação destes, para um local mais viável

Para os corrimãos dos guarda-corpos do acesso da rampa e escada, deve ser feita uma limpeza fina da superfície, para retirar as sujidades e deposições encontradas na superfície, e nos pontos de corrosão da solda, averiguar o desempenho a resistência, caso tenha sido afetado, fazer reforço soldando as emendas afetadas.

As porcas e arruelas vistas na parte superior, do espaço de convivência sombreado, devem ser verificadas quanto a seus desempenhos, se estiverem aluídas, elas devem ser substituídas. Caso estejam atendendo a solicitações que lhe são impostas, em relação a fixação da estrutura do guarda corpo de madeira, é só ser feito um isolamento dos metais, ou ser feito o uso de ligas metálicas com especificação semelhante à da chapa de fixação do guarda corpo de madeira. Segundo o CESEC/UFPR - Centro de Estudos de Engenharia Civil da Universidade Federal do Paraná, pode-se evitar a ação desse tipo de corrosão, por meio do uso de isolante entre os materiais metálicos ou fazendo uso de ligas com valores galvânicos aproximados.

No Caso 4, para a situação encontrada nos corrimãos e guarda-corpos, deve-se seguir a mesma orientação que foi dada para ser utilizada nos corrimãos dos guarda-corpos do acesso da rampa e escada do Caso 2, onde foi recomendado fazer uma limpeza na superfície, para livra-la dos resíduos dispostos e da sujeiras.

Para o destacamento do concreto, sofrido no patamar da escada e no degrau da escada que dão acesso ao Rio Sergipe, deve-se retirar a camada do aço prejudicada pela corrosão, limpar e aplicar uma proteção na superfície exposta, por meio de tintas adequadas, e obedecendo a norma ABNT NBR 6118:2014, executar o cobrimento de acordo com as orientações desta. 
No Caso 6, o serviço para reparar o desgaste da superfície do guarda-corpo de madeira, deve ser feita através de retoque de pintura com verniz, para garantir a proteção contra agentes externos e a beleza da peça no local.

Ao analisar, os Casos 3 e 5, os mais complexos em relação a reparos e revitalização, e os que mais recebem influência dos processos de ataque dos agentes agressivos externos, pode-se concluir, juntamente com Lapa (2008), que as resultantes da relação entre os íons cloretos e a carbonatação, aumentaram a agilidade do processo corrosivo nessas estruturas, equiparado a atuação separada dos agentes de ataque.

Marques (2015), afirma que as manchas acastanhadas que surgem na superfície de concreto, eflorescências, desagregação e fissuração, são as evidências visuais que demonstram a ocorrência do processo de corrosão. Mas, nem sempre a visualização dos focos do processo corrosivo é possível. Daí a necessidade da realização de ensaios.

De acordo com Ferreira (2000), são empregados distintos métodos, para se conhecer o teor de cloretos no concreto no concreto, onde habitualmente são separados em duas formas de medição, as medições entre cloretos fixos/livres e cloretos totais/livres.

E para se ter confirmação das áreas afetadas por carbonatação, Lapa (2008) fala, que pode ser realizado por meio de difração de Raio - X, termografia, análise térmica diferencial e observação por microscópio. Porém a constatação mais usual é feita por meio de fenolftaleína ou timolftaleína, que são indicadores de $\mathrm{pH}$.

Após saber os resultados dos ensaios, pode-se tomar decisões, acerca de qual método de reparo será utilizado. Cascudo (1997), sugere algumas metodologias de tratamento, em relação a corrosão de armadura, são elas: reparos feitos no local afetado, reparos feitos de forma generalizada, retirada eletroquímica dos cloretos, controle no processo catódico, eliminação do eletrólito e proteção catódica. Cada uma possui suas vantagens e desvantagens, cabe ao profissional habilitado, com base nos dados obtidos nos ensaios, verificar e escolher qual o melhor método a ser aplicado, para o reparo dos problemas identificados em cada edificação. Vale salientar, que também é viável analisar a questão de custo desses reparos, antes de escolher a melhor intervenção.

\subsection{RESPONSABILIDADES DOS ESPAÇOS PÚBLICOS}

Em visitas realizadas aos órgãos municipais e estaduais, foram coletadas informações importantes para o desenvolvimento do estudo dos espaços públicos urbanos.

Na Defesa Civil Estadual, o engenheiro civil, José Roberto Oliveira Santos, relatou que no período dos anos 60 e 78, a normatização que se seguia para construções em concreto armado, era a norma brasileira NB 1 "Projeto e execução de obras de concreto armado", a qual não se atentava muito a questão de durabilidade do material. No intervalo que compreende o ano de 1978 ao ano de 2003, que foi o ano em que a norma ABNT NBR 6118:2003 foi criada, muitas edificações em Sergipe, sofreram com a falta das práticas de cobrimento mínimo da armadura de aço e qualidade do concreto utilizado e eram construídas com concreto de fck de 15 Mpa de resistência. Essa falta de informações na normatização da época, contribuiu bastante para a degradação de várias edificações construídas naqueles anos, o que inclui a edificação do atracadouro da Av. Ivo do Prado, que teve sua primeira parte construída no ano de 1978.

Na Defesa Civil Municipal, foram fornecidos pelo fiscal de obras e urbanismo, Jorge Valdir de Souza Leite, relatórios técnicos do atracadouro da Av. Ivo do Prado e do Píer da Orla do Bairro Industrial, os quais foram elaborados perante solicitação do MPE - Ministério Público Estadual e enviados a seus respectivos responsáveis, o governo do Estado de Sergipe e a EMURB. Através dos relatórios, pôde-se ter uma noção do estado de conservação dos espaços públicos citados, no ano de 2016.

Também foi realizada visita a CEHOP, onde o engenheiro civil, Artur Luiz de Melo, da gerência de projetos, falou: "O problema da falta de cultura de manutenção no Brasil, se dá principalmente no que se diz em relação a obras públicas.". Por ele também foi fornecido um parecer técnico, referente ao atracadouro da Av. Ivo do Prado, elaborado por ele no ano de 2006, onde foi possível verificar que os problemas patológicos do local se estenderam até o decorrente ano de 2017, de forma desimpedida, sem intervenção.

Em ida a EMURB, foi conversado com o fiscal de obras, o qual comunicou que a EMURB não competia a atribuição de manutenção dos espaços públicos urbanos, informou que a Empresa Municipal de Urbanização, apenas fiscalizava e cobrava laudos de manutenção e conservação de edificações particulares, e que apenas faziam diagnósticos visuais superficiais em edificações públicas, para auxiliar 
na abertura de processos licitatório, os quais eram requeridos a eles, pela EMSURB. 0 fiscal orientou que a EMSURB fosse consultada, para a obtenção de maiores informações.

Na visitação conferida a EMSURB, mais especificadamente, a Diretoria de Espaços Públicos e Abastecimento - DIREPA, o gerente de espaços públicos, Igor Melo de Almeida, relatou que a função daquele setor era a fiscalização do uso dos espaços públicos por particulares, como por exemplo, a ocupação de áreas públicas por comerciantes com estabelecimentos fixos, e o abastecimento do mercado municipal. Foi informado também, que não cabe a eles a manutenção dos espaços públicos urbanos, principalmente em relação a manutenção e conservação de estruturas destes, pois os fiscais atuantes nesse setor, não possuem conhecimentos técnico para tal.

Portanto, com base nos relatos, mesmo com a falta de informação, pode-se presumir a falta de um manual de uso e manutenção dos espaços públicos urbanos, assim como também a inexistência de Programa de Manutenção, com objetivo de protelar o aparecimento de problemas, como comenta Brasil (2013).

0 fato de não possuir manual, nem programa de manutenção, as manifestações patológicas averiguadas nos 6 espaços públicos urbanos estudados, tendem a progredir por não serem administradas, com auxílio das manutenções corretivas. Caso não seja feita nenhuma intervenção, ao longo do tempo as manifestações patológicas encontradas, poderão virar um sério problema para a estrutura do espaço público, que irão requerer maior custo para reparo ou reconstrução.

\section{CONCLUSÃO}

Através dos objetos de estudo escolhidos, foram percebidos diferentes níveis de estados patológicos e de conservação. Alguns espaços públicos urbanos, como a Ponte do Imperador Dom Pedro II e a $2^{\circ}$ etapa da Orla do Bairro Industrial, se apresentaram conservados, por terem passado recentemente por reforma de revitalização, porém ainda assim apresentaram já iniciado algum indício patológico que posteriormente, caso não seja dada manutenção adequada, se tornará em manifestação definitiva do processo corrosivo. Porém, nos demais espaços públicos estudados, o Mirante do calçadão 13 de Julho, o Calçadão da Praia Formosa, considera-se que a corrosão já se encontra impregnada na estrutura e que uma intervenção urgente se faz necessário a fim de evitar maiores problemas estruturais, acidentes e majoração dos prejuízos materiais.

As formas de corrosão mais severas e intensas, foram encontradas no estudo das estruturas dos espaços públicos localizados submersos no Rio Sergipe, no caso 3 - Atracadouro da Av. Ivo do Prado e no caso 5 Píer da $1^{\circ}$ etapa da Orla do Bairro Industrial, onde a influência da variação e respingos de maré se faziam presentes bem como a ausência de manutenção, agravando a situação, o que culminou na degradação acelerada do concreto e da armadura, e consequentemente na interdição dos espaços.

Um fato a ser destacado, é a negligência e o descaso por parte dos órgãos responsáveis pela manutenção e conservação dos espaços públicos no município de Aracaju, EMURB E EMSURB, que não possuem (ou não apresentaram), em visita, plano de manutenção, e por parte do governo, que prefere inaugurar novos espaços públicos, ao invés de revitalizar e manter os já existentes.

As análises e propostas de solução sugeridas para os problemas encontrados demonstram a importância e necessidade do cumprimento das normas, da elaboração do manual de manutenção e uso dos espaços, e implantação de um sistema de planejamento de manutenção permanente, pelos órgãos responsáveis pela administração e conservação dos espaços públicos urbanos da cidade.

Como as análises do estudo de caso foram embasadas na inspeção visual (qualitativa), não foi possível gerar informações quantitativas suficientes para a confecção de relatórios que abordassem o âmbito da recuperação estrutural. Desta forma, recomenda-se que sejam feitas análises mais profundas da incidência e tratamentos das patologias de corrosão encontradas, por conseguinte, dando mais confiabilidade aos serviços futuros que poderão ser executados.

Diante do quadro visualizado neste trabalho, com base nos espaços públicos analisados, também sugerese a promoção de uma campanha regional para conscientização da população sobre a conservação de espaços públicos e educação ambiental. 


\section{REFERÊNCIAS}

[1] ASSOCIAÇÃO BRASILEIRA DE NORMAS TÉCNICAS - ABNT. NBR 6118. Projeto e Execução de Obras de Concreto Armado. Rio de Janeiro: 2014, 238p.

[2] BERTOLINI, L. Materiais de construção: patologia, reabilitação, prevenção - São Paulo: Editora Oficina de textos, 414p., 2010.

[3] BRASIL. Departamento Nacional de Infraestrutura de Transportes. Diretoria Executiva. Instituto de Pesquisas Rodoviárias. Manual de recuperação de pontes e viadutos rodoviários. - Rio de Janeiro, 159p. (IPR. Publ., 744) 2010.

[4] BRASIL. Tribunal de Contas da União. Obras públicas: recomendações básicas

[5] CASCUDO, 0. O controle da corrosão de armaduras em concreto - inspeção e técnicas eletroquímicas. Co-edição, São Paulo: Ed. PINI, Goiânia: Ed. UFG, 1997.

[6] CESEC/UFPR - Centro de Estudos de Engenharia Civil da Universidade Federal do Paraná Corrosão em estruturas metálicas Disponivel em: <http://wwwo.metalica.com.br/corrosao-emestruturas-metalicas> Acesso em 22 maio 2017.

[7] COELHO, P. Diferentes tipos e formas de corrosão. Disponível em <http://www.engquimicasantossp.com.br/2015/06/diferentes-tipos-e-formas-decorrosao.html\#ixzz4iR2TBx00>. Acesso em 10 de Abril de 2017.

[8] FÁVERI, R.; SILVA, A.. Método gut aplicado à gestão de risco de desastres: UMA FERRAMENTA DE AUXÍLIO PARA HIERARQUIZAÇÃO DE RISCOS. REVISTA ORDEM PÚBLICA, v. 9, n. 1, 2016.

[9] FERREIRA, R. M. Avaliação dos ensaios de durabilidade do betão. 2000. 246 f. Dissertação (Mestrado em Engenharia Civil) - Escola de Engenharia, Universidade do Minho, Braga, 2000.

[10] FIGUEROLA, V. Vazios de concretagem: cuidados especiais com a armação e uso de produtos para alterar características do concreto podem evitar a formação das "bicheiras". Techne 109, abr./2006. Disponível em: < http://www.joinville.udesc.br/portal/professores/carmeane/materiais/Vazios_de_ Concretagem_Techne_109.pdf> Acesso em 13 de Maio de 2017.

[11] FREIRE, C. Proteção contra Corrosão. Brasil: Portal Metálica Construção Civil, 2009. Disponível em:<http://wwwo.metalica.com.br/protecao-contra-corrosao>. Acesso em 11 maio 2017.

[12] GENTIL, V. Corrosão. 3ed. Rio de Janeiro: LTC, 1996. GENTIL, V. Corrosão. 4⿳亠丷a ed. Rio de Janeiro: LTC Editora, 2003.

[13] GOMES, A. Patologias na construção civil. São Paulo, 2016. Disponível em: <http://www.unumarquitetura.com/single-post/2016/1/11/PATOLOGIAS-NA-CONSTRUÇÃO-CIVIL>. Acesso em 31 março 2017.

[14] HELENE, P. R. L. Corrosão em armaduras para concreto armado. São Paulo: PINI, 1986.

[15] LAPA, J S. Patologia, recuperação e reparo das estruturas de concreto. Monografia (Especialização em Construção Civil) - Universidade Federal de Minas Gerais. 2008.

[16] MAGNAN, M. C. Pintura na proteção anticorrosiva. Monografia (Curso de Tecnologia em Construção Naval) - CENTRO UNIVERSITÁRIO ESTADUAL DA ZONA OESTE.Rio de Janeiro. 2011.

[17] MARQUES, V. S. Recuperação de estruturas submetidas à corrosão de armaduras: definição das variáveis que interferem no custo. 2015. Monografia. Universidade Federal do Rio Grande do Sul. UFRGS, 2015.

[18] PANNONI, F. D. Manual de construção em aço: projeto e durabilidade. São Paulo: CBCA, 71 p, 2009.

[19] para a contratação e fiscalização de obras públicas /Tribunal de Contas da União. - 3. ed. Brasília : TCU, SecobEdif, 2013.

[20] SILVA. S. D. A Solução para cada Aplicação Informações técnicas sobre tintas líquidas. Desenvolvimento Tecnológico $\mathrm{n} \quad$ 12. Rev. 3. 2009. Disponível em $<$ http://ecatalog.weg.net/files/wegnet/WEG-apostila-curso-dt-12-pintura-industrial-com-tintas-liquidastreinamento-portugues-br.pdf $>$. Acesso em 10 de Abril de 2017.

[21] SOUZA, V. C.; RIPPER, T. Patologia, recuperação e reforço de estruturas de concreto. São Paulo: Pini, 1998. $255 \mathrm{p}$. 
[22] VERZOLA, S.; MARCHIORI, F. F.; ARAGON, J.O. Proposta de lista de verificação para inspeção predial $\mathrm{x}$ urgência das manutenções. In: XV ENCONTRO NACIONAL DE TECNOLOGIA DO AMBIENTE CONSTRUÍDO, ENTAC, $11, \quad 2014.2$ Maceió.Disponível em <http://www.infohab.org.br/entac2014/artigos/paper_300.pdf>. Acesso em 21 de Abril de 2017. 


\section{Capítulo 8}

\section{Métodos investigativos do subsolo para dimensionamento de fundações de edificações de baixo custo}

\section{Jailton Vieira dos Santos Neto}

Resumo: A elaboração de um projeto de fundação deve está associada à análise minuciosa da investigação geotécnica. Essa análise tem como objetivo identificar dentre todas as possiblidades existentes de fundação a mais adequada para o terreno objeto de estudo. No caso específico, foi realizado um estudo comparativo entre duas áreas relativamente próximas com características litológicas destoantes. Com o fornecimento dos dados oferecidos pela empresa Consistent Engenharia, e através de uma pesquisa realizada com profissionais da área, obteve-se informações que subsidiaram a apresentação dos resultados. Em razão do alarmante resultado, percebeu-se que os profissionais, normalmente, negligenciam essa etapa extremamente relevante para fornecimento de informações que serão utilizados na elaboração do projeto de fundação.

Palavras-chave: Investigação geotécnica. Projeto de fundação. Litológicas. 


\section{INTRODUÇÃO}

A idealização de qualquer projeto de Engenharia Civil precisa ser antecedido por um protocolo técnico que deve ser criteriosamente seguido. Quando se planeja iniciar uma construção em um determinado lote/terreno, a equipe multidisciplinar deve solicitar, imediatamente, a realização de uma investigação geotécnica. Com a apresentação dos dados, fruto da sondagem realizada e com a certeza da viabilidade econômica, inicia-se a elaboração do projeto de fundação. As sondagens realizadas na região produzirão resultados transcritos em laudos que serão avaliados por profissionais da área, para que possam analisar as características das camadas do maciço e traçar um pré-projeto de fundação que atenda as peculiaridades do terreno. 0 projetista visitará o local onde se pretende construir, junto com o responsável pela execução das investigações, para que possam ajustar as divergências e observar características do perfil geotécnico que estejam em evidência no local.

É notório que a figura do projetista de fundação é algo indispensável. Ele deve está envolvido com todo o processo de investigação do subsolo e ciente das suas responsabilidades e de que precisa desenvolver um projeto que garanta a estabilidade da estrutura e que possa utilizar a fundação como transmissora de cargas até o maciço, que por sua vez, deverá absorvê-las sem submeter-se ao cisalhamento.

Este trabalho busca alertar os profissionais de Engenharia sobre a importância de uma boa investigação geotécnica e de quanto essa refletirá na elaboração adequada do projeto, evitando gastos desnecessários, escolhas de fundação inadequada e garantindo que ela corresponda aos esforços que serão aplicados.

Através de uma pesquisa bibliográfica e do estudo de um caso real,o objetivo geral é, identificar entre todas as possibilidades apresentadas de métodos investigativos do subsolo, quais as mais adequadas para edificações de menor custo. Em se tratando dos objetivos específicos: apresentar a diversidade de métodos investigativos, enfatizando a técnica mais usual para obras de baixo custo; validar através da pesquisa de campo a heterogeneidade do maciço em se tratando de terrenos próximos; e, realizar um estudo comparativo de custo entre projetos de fundação e investigação distintas.

\section{METODOLOGIA}

Este trabalho baseou-se, primeiramente, em realizar uma pesquisa bibliográfica sobre o tema e, em seguida, uma pesquisa de campo executada por meio de entrevistas, análise de relatórios técnicos, perfis de sondagens e projetos.

\section{1 ÁREAS DE ESTUDO}

Projetada pelo engenheiro Sebastião José Basílio Pirro e elevada à categoria de cidade em 17 de março de 1855, a capital do estado de Sergipe, conforme representado na figura 5, Aracaju, possui uma população estimada, segundo censo do IBGE (2017) de 650.106 habitantes. Segundo divulgado no site da Prefeitura Municipal, o município possui uma extensão territorial de $181,9 \mathrm{~km}^{2}$, subdividido fisicamente em 39 bairros. 0 bairro, em que a pesquisa foi desenvolvida, está localizado à zona oeste da capital sergipana, denominado Jabutiana, representado pelo número 26, Figura 6.

Figura 5: Mapa do Brasil.

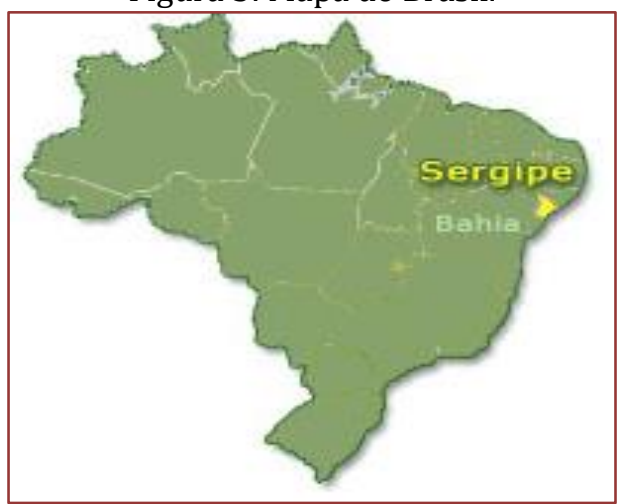

Fonte: IBGE (2017) 
Figura 6: Subdivisão bairros de Aracaju.

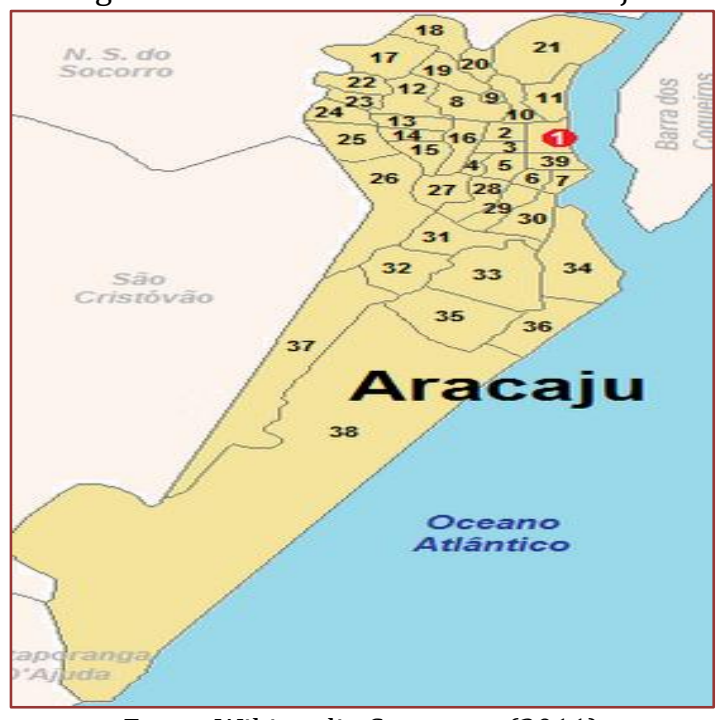

Fonte: Wikimedia Commons (2011)

A presente pesquisa baseou-se no estudo de duas áreas. Uma das áreas de realização do estudo de caso está localizada na Rua Major João Teles, onde funciona atualmente o Colégio Michelangelo. Já a outra área de estudo, localiza-se na rua Antônio Nascimento Rodrigues. As duas áreas estão localizadas no bairro Jabutiana e listam, entre si de, aproximadamente, 620 metros, conforme ilustra figura 7 abaixo.

Figura 7: Mapa de localização das áreas.

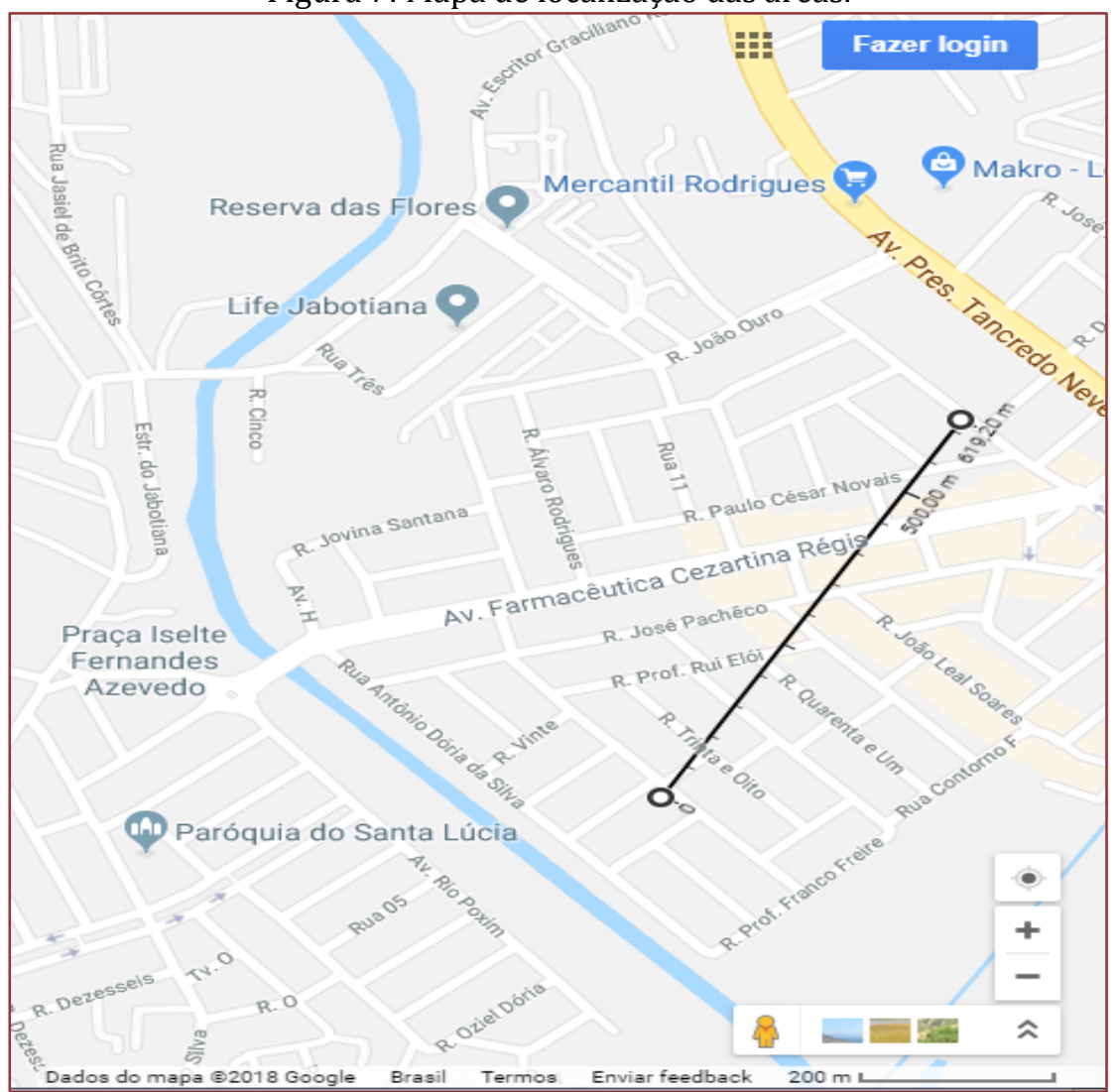

Fonte: Google Maps (2018) 


\subsection{COLETA DE DADOS}

O desenvolvimento desse trabalho se deu através de consulta a referências bibliográficas, dentre elas, ABNT NBR 6502:1995, ABNT NBR 9604:2016 e ABNT NBR 9603:2015, como também as monografias, artigos, teses e livros relacionados ao tema. Foram utilizados também os relatórios técnicos resultantes dos trabalhos de campo investigativos do subsolo.

A aplicação do estudo de caso foi realizada através da coleta de informações geotécnicas, fornecidas pela empresa Consistent Sondagens, que executou procedimentos investigativos do maciço para obtenção de dados solicitados pelos clientes.

\subsection{ANÁLISE E INTERPRETAÇÃO DOS RESULTADOS}

Baseado na disponibilização dos resultados de investigação do subsolo fornecidos pela empresa Consistent Sondagens foram verificados os dados descritos nos perfis e realizada uma interpretação técnica, objetivando a escolha adequada da fundação e subsidiando os profissionais de projeto para o estudo de viabilidade econômica da construção.

A análise dos resultados será baseada nos resultados da investigação do subsolo para as duas áreas estudadas, objetivando definir o tipo de fundação mais adequada.

\section{RESULTADOS E DISCUSSÃO}

\subsection{CARACTERÍSTICAS DAS OBRAS}

A primeira obra objeto de estudo consiste na ampliação da unidade de ensino localizado no bairro Jabutiana. A construção do anexo está atrelada à ampliação do Colégio Michelângelo, composta por três (3) pavimentos, contemplando: salas de aula, administração, banheiros, copa e recreação. A outra área utilizada na análise comparativa está a 620 metros da primeira e consiste na edificação residencial, com $250 \mathrm{~m}^{2}$ de área, contemplando: garagem, salas de estar e jantar, banheiros, cozinha e quartos.

\subsection{SONDAGENS NA ÁREA 1}

De acordo com os relatórios apresentados para o contratante, na área 1 (Construção do anexo Colégio Michelângelo), sete (7) furos foram realizados conforme posicionamento definido pelo solicitante e representado nos croqui abaixo. Observa-se que dos sete locais previamente escolhidos, dois foram deslocados, SP-01 e SP-02, em razão das características identificadas "in loco". Os novos pontos de sondagens passaram a ser denominados de SP-01A e SP-02A. Essa primeira insvestigação do subsolo ocorreu no período de doze (12) a dezesseis (16) de dezembro de dois mil e dezesseis (2016), cuja técnica utilizada foi a sondagem a percussão (SPT) conforme as orientações previstas na ABNT NBR 6484:2001 e de acordo com a Figura 8, representada a seguir.

Figura 8: Projeto de locação dos furos de sondagens.

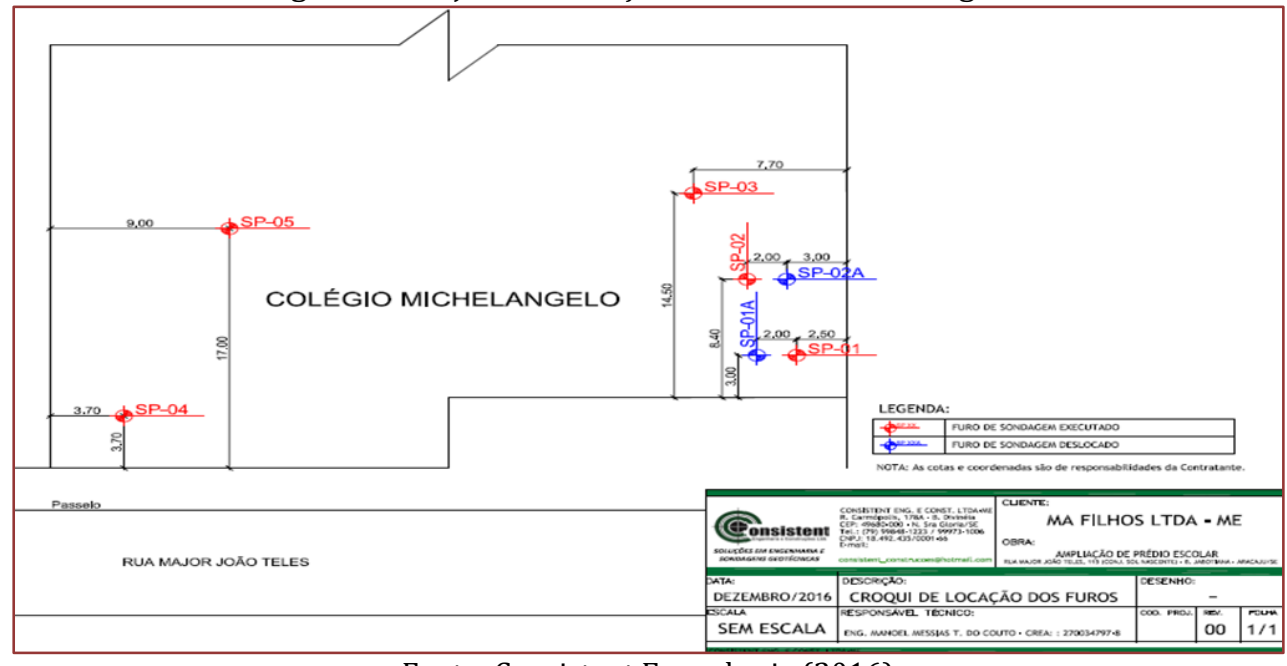

Fonte: Consistent Engenharia (2016) 
Nos perfis apresentados por essas sete sondagens, observou-se uma relativa equidade entre as classificações do material presente no maciço. Apesar da leve variação do nível da água, sendo detectada a 1,27 metros no SP-05 (menor profundidade) e 1,50 metros no SP-01A (maior profundidade), não apresentou mudança, nem impedimento à execução da fundação. Além dessas observações, um ponto de extrema importância e indispensável para realização do projeto de fundação é a resistência à penetração. Nesse caso, os perfis apresentados apontaram uma resistência considerável a uma profundidade em torno de 7,52 metros, conforme apresenta a Figura 9.

Figura 9: Perfil individual de Sondagem a Percussão-SPT.

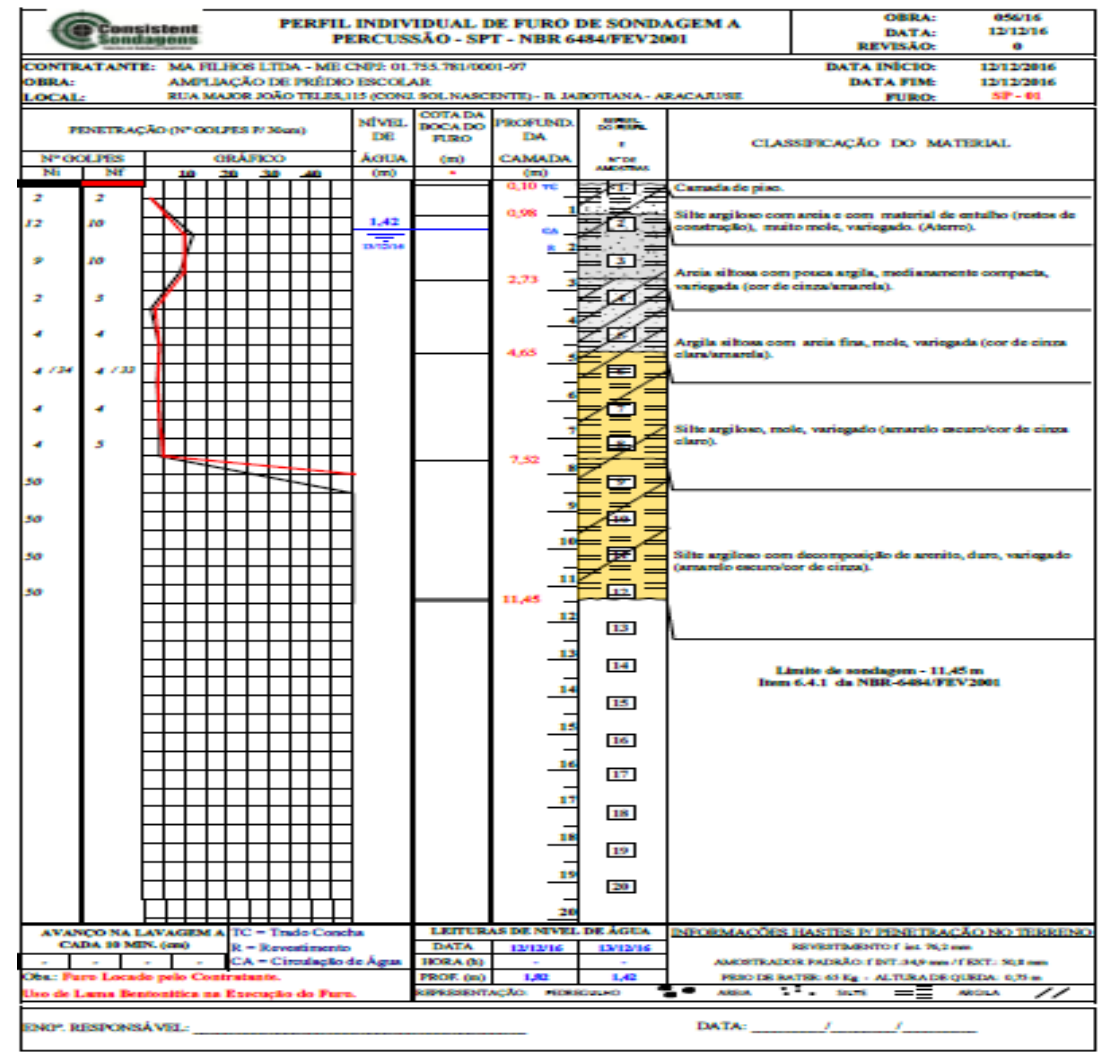

Fonte: Consistent Engenharia (2016)

Com a obtenção de todos os dados descritos em laudos geotécnicos, uma equipe de profissionais de engenharia discutiu, dentre as diversas possibilidades de escolha da fundação, qual seria a mais viável economicamente e qual apresentaria uma execução célere para garantir a finalização da proposta, conforme a necessidade do cliente. Após essa análise aprofundada, optou-se pela execução de fundação profunda do tipo estaca metálica.

Figura 10: Execução de sondagem.

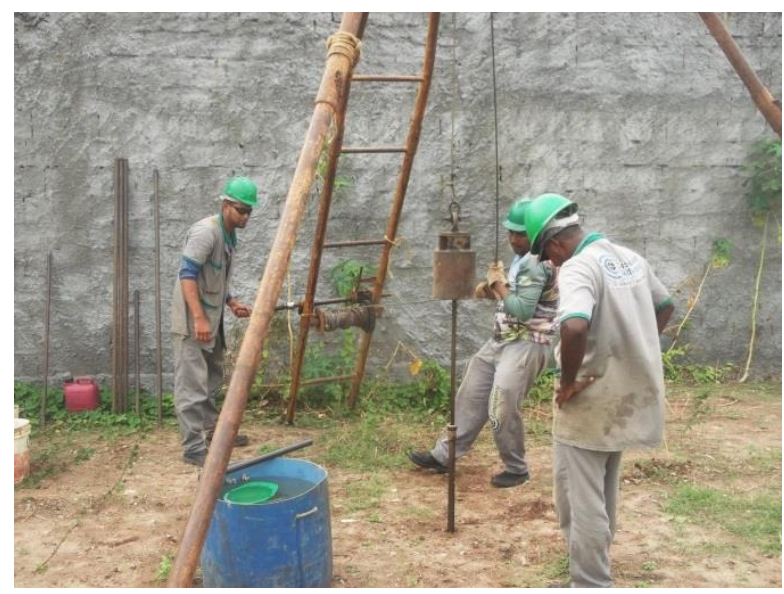

Fonte: Consistent Engennharia (2016). 


\subsection{SONDAGENS NA ÁREA 2}

De acordo com os resultados apresentados ao cliente e registrado em dois perfis de sondagens executados entre os dias oito (8) e nove (9) de agosto de dois mil e dezessete (2017), observou-se que a resistência a penetração das camadas rochosas apresentou dados extremamente baixos, não ultrapassando 4 golpes por $45 \mathrm{~cm}$. Com a realização da sondagem, prospectou um material representativo de cada litologia e o classificou como sendo uma argila orgânica siltosa muito mole. Em decorrência dessa baixa resistência, o contratante solicitou a interrupção do ensaio geotécnico para discutir com o engenheiro contratado para elaboração do projeto a viabilidade na aquisição do imóvel ou se era prudente suspender a negociação de compra e venda da área. A Figura 11 apresenta o perfil de sondagem a percussão (SPT) da área dois (2).

Figura 11: Perfil individual de Sondagem a Percussão-SPT.

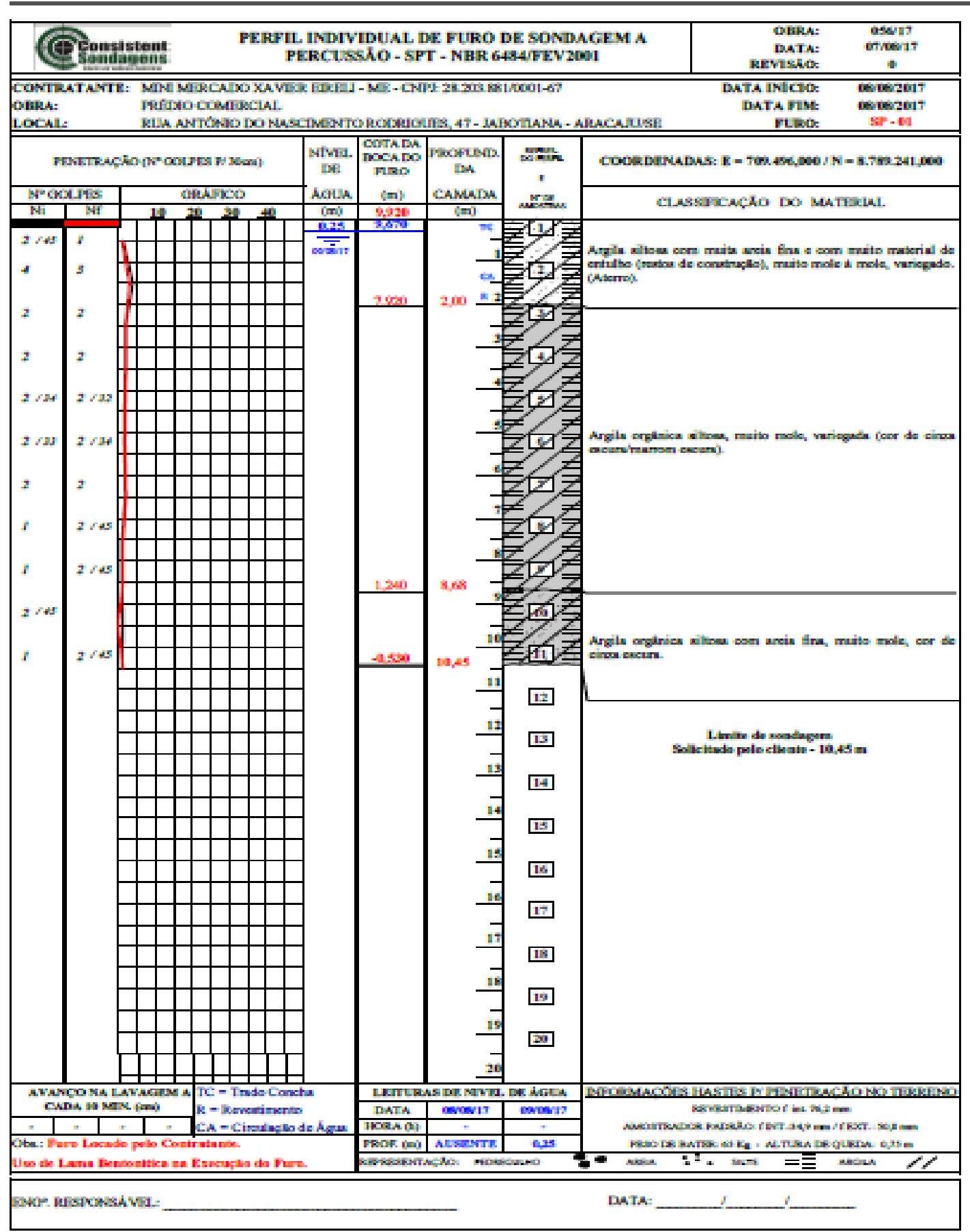

Fonte: Consistent Engenharia (2016) 


\subsection{APRESENTAÇÃO DOS DADOS DA PESQUISA}

Em uma pesquisa realizada no período de 20 a 22 de maio de 2018, com alunos do décimo período de Engenharia Civil da Faculdade Pio Décimo e engenheiros civis com até dez anos de formação, foi aplicado um questionário, sendo subdividido em três perguntas. No total, houve a abordagem a cinquenta e um (51) entrevistados, sendo trinta (30) estudantes concludentes e vinte e um (21) profissionais formados, onde foram realizadas as seguintes indagações:

a) Durante sua vida acadêmica foi ressaltada a importância da investigação geotécnica antes de iniciar qualquer obra de Engenharia Civil?

Do total de 51 entrevistados, 6 responderam que não houve informações que retratasse a importância da investigação geotécnica durante a vida acadêmica, os 45 restantes responderam que durante a graduação foram informados sobre a relevância dessa etapa. A Figura 12 esquematiza os dados obtidos com esta pergunta.

Figura 12: Importância da investigação geotécnica.

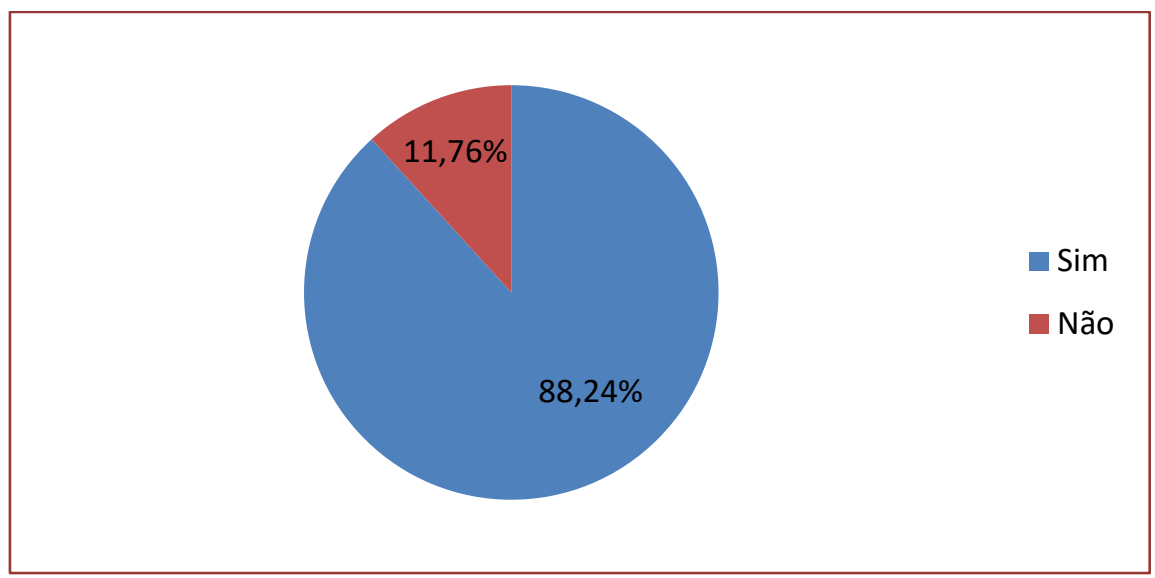

Fonte: Autor (2018)

b) Sendo você o engenheiro civil responsável por uma obra de pequeno porte, haveria necessidade de contratação de uma empresa para investigação do subsolo?

Em um total de 51 entrevistados, 15 responderam que não contratariam uma empresa para investigação do subsolo em se tratando de obras de pequeno porte e os 36 demais disseram que contratariam. A Figura 13 apresenta os resultados obtidos

Figura 13: Há necessidade de realização de ensaio para todas as obras.

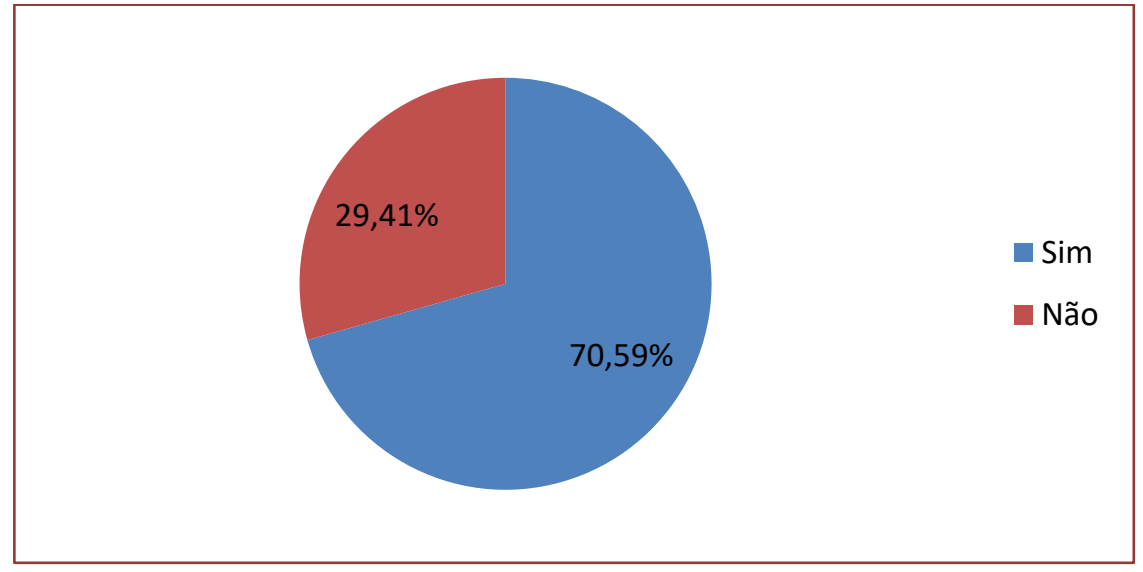


c) Havendo conhecimento das características do subsolo na obra ao lado, em razão de uma sondagem já realizada e se houvesse o fornecimento dos dados da sondagem, você, engenheiro civil, responsável pela elaboração do projeto de fundação, contrataria uma empresa para investigação geotécnica para traçar as características do subsolo da nova área?

Dos 51 entrevistados, 2 optaram por não responder, 23 responderam que não contratariam uma nova empresa e 26 se manifestaram a favor da contratação. As respostas dessa pergunta estão representadas na Figura 14.

Figura 14: Utilização de dados da sondagem da obra ao lado.

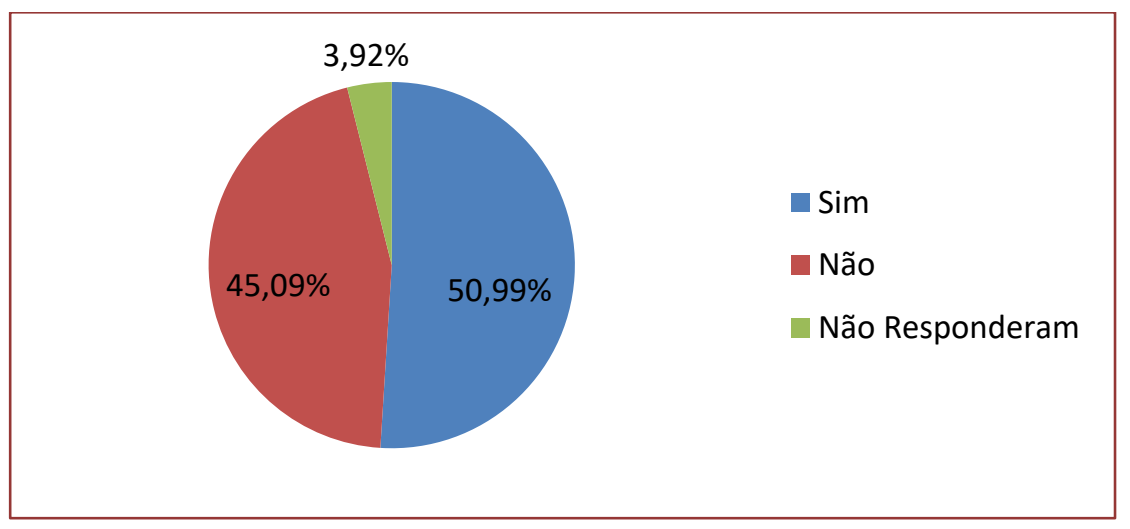

Fonte: Autor (2018)

\subsection{ANÁLISE ORÇAMENTÁRIA DO IMPACTO NO VALOR FINAL DA OBRA}

Diante dos dados apresentados na pesquisa realizada foi questionado o motivo pelo qual quase $50 \%$ dos profissionais suprimem a primeira etapa antes da elaboração do projeto de fundação. A primeira suspeita seria o custo ao valor final do empreendimento. Porém, foi solicitado à empresa o fornecimento de dados referente ao valor cobrado para realização de sondagens em terrenos de pequeno porte localizado no município de Aracaju. Foram fornecidos os dados apresentados no Tabela 1.

Tabela 1: Dados referentes aos valores cobrados em sondagens SPT.

\begin{tabular}{|c|c|c|c|}
\hline \multicolumn{4}{|c|}{ Planilha Orçamentária ( obras até $200 \mathrm{~m}^{2}$ )- SPT } \\
\hline & rio & Mobilização & Valor total $(\mathrm{Vu}+\mathrm{Mo})$ \\
\hline 01 metro/ Furo & $\mathrm{R} \$ 67,00$ & $\mathrm{R} \$ 1.000,00$ & $\mathrm{R} \$ 1.067,00$ \\
\hline 08 metros & $R \$ 536,00$ & $\mathrm{R} \$ 1.000,00$ & $\mathrm{R} \$ 1.536,00$ \\
\hline
\end{tabular}

\subsection{DISCUSSÃO DOS RESULTADOS}

De acordo com Velloso e Lopes (2010), é necessário que haja um envolvimento do responsável pelo projeto de fundação com o processo de investigação do subsolo desde o início. Com todos os dados fornecidos pela empresa responsável pela investigação geotécnica, o projetista deverá comparecer ao local da obra, junto com o responsável pelos dados apresentados, para verificar "in loco", feições geológicasgeotécnicas importantes, assim como identificar erosões, presença de taludes, afloramentos e tantos outros pontos indispensáveis para elaboração do projeto de fundação.

Como constatado nos dados apresentados nesse trabalho, observou-se que, apesar da proximidade entre os terrenos, foi apresentada características distintas, não podendo levar em consideração, exclusivamente, a orientação de alguns profissionais que propõe a utilização da mesma fundação projetada para o terreno vizinho. Sabe-se que suprimindo essa etapa durante o processo de elaboração do projeto de fundação, haveria no primeiro caso (ampliação do Colégio Michelangelo) a escolha de uma fundação que não corresponderia com as características locais, colocando todo o investimento em risco e podendo trazer prejuízos significativos e em muitos casos irreversíveis ao proprietário. Já no segundo caso, onde foi 
sabiamente orientado pelo profissional de engenharia a solicitação da investigação geotécnica antes da compra do imóvel, percebeu-se que as características apresentadas pelas camadas do maciço inviabilizariam a construção, sendo abortada a negociação que vinha sendo realizada. Percebe-se, claramente, uma atitude técnica, baseada nas orientações literárias, já que suprimir essa etapa construtiva é colocar em risco a integridade física de diversas pessoas que usariam o estabelecimento assim como, a garantia da continuidade do exercício profissional.

Conforme representado nos gráficos anteriores, observou-se através do posicionamento dos entrevistados que, segundo a Figura 12, 88,2 \% dos profissionais aprenderam durante a vida acadêmica a relevância da investigação geotécnica para escolha adequada da fundação. Ou seja, trata-se de um procedimento técnico vital em qualquer tipo de obra, sendo indispensável a investigação do subsolo. Definir a fundação exige a análise dos dados e informações de áreas afins: topografia do local, dados de erosão, investigação do subsolo, cargas da estrutura e construções vizinhas. Observa-se que, em razão da relevância desse procedimento, durante a vida acadêmica, diversas disciplinas deverão subsidiar os discentes de informação para garantir que quando estiverem exercendo sua carreira profissional exijam a investigação do subsolo e façam cumprir todas as determinações contidas em norma. (HACHICH,1988),

Já na Figura 13, quando perguntado se haveria necessidade de contratação de uma empresa para realização de uma sondagem em uma obra de baixo custo, $29,4 \%$ dos entrevistados responderam que não contratariam. Essa atitude inadequada dos entrevistados contraria o que prevê boa parte da literatura. Segundo Pinto (2006), a execução da investigação do subsolo refletirá na escolha adequada da fundação e, consequentemente, na estabilidade da estrutura. A interação entre terreno-fundação-estrutura precisa ser sincrônica objetivando evitar patologias na fundação, além de absorver as cargas provenientes da superestrutura transmitindo ao terreno de forma segura. A tomada de decisão inadequada, ao suprimir essa etapa essencial da elaboração do projeto, põe em risco inúmeras estruturas, já que, ocorre o dimensionamento e a escolha adequada da fundação incompatível com a realidade local.

Na Figura 14, observou-se que 45,09\% dos entrevistados afirmaram que não realizariam a sondagem caso houvesse dados fornecidos por uma empresa que realizou o procedimento na obra vizinha. Essa atitude é preocupante. Segundo Grotzinger e Jordan (2013) há três princípios que definem a estratigrafia, sendo denominados princípios de Steno, um deles corresponde ao princípio da continuidade lateral do estrato. Esse princípio em diversos casos não pode ser levado em consideração, já que, conforme verificado nos perfis de sondagens apresentados anteriormente, não há uma equidade na relação estratigráfica local. Essa heterogeneidade observada na comparação de ambos os casos, deixa evidente que não é seguro, ético, tampouco técnico, deixar de exigir a realização da sondagem independente do fornecimento de dados do subsolo por obra vizinha. Afinal, não se pode garantir que as camadas estão dispostas paralelamente e que as características das amostras apresentadas na obra ao lado sejam idênticas as da nova obra.

Foi verificado também o impacto que a realização de uma sondagem causaria no custo final da obra, já que para Velloso e Lopes (2004), o primeiro passo para avaliar as características do subsolo é definir as etapas da investigação, tais como: investigação preliminar; investigação complementar; e, investigação para fase de execução. Talvez o custo elevado fosse um dos entraves que impede os profissionais de não realizarem esse procedimento investigativo. Porém, conforme apresentado no Quadro 1, anteriormente mencionado, a porcentagem representativa da realização da sondagem no custo final da obra seria em torno de $2 \%$. Esse valor é relativamente baixo quando confrontado com o risco que a inexistência dessa etapa executiva poderá trazer a todos os envolvidos.

\section{CONCLUSÃo}

Concluir que, apesar de grande parte da literatura relatar a indispensabilidade do procedimento investigativo do subsolo durante a elaboração de um projeto, ainda há profissionais de engenharia que contrariam essa exigência normativa, desrespeitando diversos estudos na área e colocando em risco o investimento financeiro realizado pelo cliente. Essa omissão na realização dos ensaios resultaria no desenvolvimento de projetos de fundação incompatíveis com a realidade local assim como favoreceria o aparecimento de patologias, podendo gerar danos irreversíveis.

Toda essa problemática foi ratificada no decorrer desse trabalho, quando da apresentação dos dados descritos no estudo de caso que retratou a disparidade observada nas características do solo e suas respectivas resistências, mesmo se tratando de terrenos com uma distância relativamente próxima. 0 objetivo foi desmistificar uma prática bastante usual na construção civil, onde ocorre a construção de 
edificações sem a averiguação das características do subsolo, alertando os profissionais acerca da necessidade irrefutável de realização dessa etapa construtiva para definição adequada do projeto de fundação.

Como tema para trabalhos futuros propõe-se levantar os custos dos diversos tipos de métodos investigativos do subsolo e o seu valor, em percentual, no custo total da obra.

\section{REFERENCIAS}

[1] ASSOCIAÇÃO BRASILEIRA DE NORMAS TÉCNICAS - ABNT NBR 6122: Projeto e execução da fundação. Rio de janeiro, 2010.

[2] ASSOCIAÇÃO BRASILEIRA DE NORMAS TÉCNICAS - ABNT NBR 6502: Solos e Rochas. Rio de Janeiro, 1995.

[3] ASSOCIAÇÃO BRASILEIRA DE NORMAS TÉCNICAS - ABNT NBR 6484: Solo-Sondagens de simples reconhecimento com SPT-Métodos de ensaio. Rio de janeiro, 2001.

[4] ASSOCIAÇ̃̃O BRASILEIRA DE NORMAS TÉCNICAS - ABNT NBR 8036: Programação de sondagens de simples reconhecimento dos solos para fundação de edifício, Rio de Janeiro, 1983.

[5] ASSOCIAÇÃO BRASILEIRA DE NORMAS TÉCNICAS - ABNT NBR 9603: Sondagem a trado. Rio de Janeiro, 2015.

[6] ASSOCIAÇ̃̃O BRASILEIRA DE NORMAS TÉCNICAS- ABNT NBR 9604: Abertura de poços e trincheira de inspeção em solo, com retirada de amostras deformadas e indeformadas. Rio de Janeiro, 2016.

[7] CAPUTO, HOMERO PINTO. Mecânica dos solos e suas aplicações. Vol. 1, Rio de Janeiro: Livros Técnicos e Científicos, 1988.

[8] GROTZINGER, JOHN; JORDAN, TOM. Para entender a Terra. São Paulo: Saraiva, 2013.

[9] HACHICH, WALDEMAR. Fundações: teoria e prática .2. ed. São Paulo: Pini,1998.

[10] HACHIC, WALDEMAR; FALCONI, FREDERICO F.; SAES, JOSÉ LUIZ e outros. Fundações Teoria e Prática. São Paulo: ABMS/ABEF, 1996.

[11] INSTITUTO BRASILEIROS DE GEOGRAFIA E ESTATÍSTICA - IBGE, Dados do município de Aracaju<https://cidades.ibge.gov.br/brasil/se/aracaju/panorama>, acesso em 25/05/2018.

[12] JUNIOR, OSVALDO GOMES DE HOLANDA. Interação solo estrutura para edifícios de concreto armado sobre fundações diretas. São Carlos, 1998.

[13] MAGALHÃES, PAULO HENRIQUE LOURENÇO. Avaliação dos métodos decapacidade de carga e recalque de estacas hélice contínua via provas de carga- DISSERTAÇÃO DE MESTRADO EM GEOTECNIA. UNIVERSIDADE DE BRASÍLIA, 2005.

[14] MILITITSKY, JARBAS; CONSOLI, NILO CESAR; SCHNAID, FERNANDO. Patologia das Fundações. São Paulo: Oficina de Textos, 2008.

[15] MINOZZO, MAIELY; SAVARIS, GUSTAVO; COSTA, GUILHERME ALAN SOUZA; JUNIOR, SÉRGIO ANTÔNIO BRUM. A importância da investigação do subsolo no dimensionamento de fundações. Congresso Técnico Científico da Engenharia e da Agronomia, 2016.

[16] NOGAMI, JOB SHUJI e VILLIBOR, DOUGLAS FADUL. Pavimentação de Baixo custo com solos Lateríticos. São Paulo: Editora Vilibor, 1995.

[17] OLIVEIRA , CINTIA ARAÚJO E AMARO, MARIA RAFAELA GONÇALVES Dimensionamento de tubulão a ar comprimido- UNIVERSIDADE DO VALE DO PARAIBA,2016.

[18] PINTO, CARLOS DE SOUSA. Propriedades dos solos. In: HACHICH, W. et al. Fundações: teoria e prática. 2 ed. São Paulo:1998.

[19] PINTO, CARLOS DE SOUSA. Curso básico de mecânica dos solos. São Paulo: Oficina de textos, 2006.

[20] REBELLO, YOPANAN CONRADO. Guia Prático de Projeto, Execução e

Dimensionamento. São Paulo, 2008. 
[21] VELLOSO, DIRCEU A.; LOPES, FRANCISCO R. Fundações. São Paulo: Oficina de textos, 2004.

[22] VELLOSO, DIRCEU DE ALENCAR E LOPES, FRANCISCO DE REZENDE. Fundações Profundas. Vol. 2. Oficina de textos: Rio de Janeiro, 2012. 


\section{Capítulo 9}

\section{Análise da aplicação da impressão 3D na construção civil}

\section{Joyce Helly da Anunciação Soares \\ Jorge Eduardo Fontes Leite}

Resumo: A evolução da construção civil vem acontecendo em diversos estágios, caracterizados principalmente pelos métodos e equipamentos empregados. Atualmente, os canteiros de obra apresentam alto índice de mecanização com a implantação de tecnologias e automação. Desta forma, a impressão tridimensional de concreto surge como um novo método construtivo com o intuito de sanar problemas de baixa produtividade e elevados custos no setor. 0 processo de fabricação digital por deposição de camadas já é amplamente utilizado em diversos setores brasileiros, conferindo-lhes os mais variados benefícios. No setor construtivo encontra-se em fase de testes e aperfeiçoamento. A partir da aplicação de um questionário a duas empresas que atuam nesse segmento no Brasil, foi possível analisar quanti/qualitativamente as respostas obtidas. Através do método indutivo, concebemos uma ideia geral acerca da aplicabilidade dessa tecnologia, seus benefícios e dificuldades de implantação na indústria da construção civil. Evidenciou-se que dentre os principais entraves estão: o devido controle de características tanto da mistura quanto da máquina a ser utilizada no processo e, o alto investimento inicial necessário para desenvolvimento do produto. Além disso, a aplicação dessa tecnologia tanto na manufatura de pré-fabricados não estruturais, quanto de paredes, proporciona redução de prazos, de desperdício de insumos, custos na mão-de-obra e, maior liberdade geométrica de peças e padronização em massa.

Palavras-chave: Construção Civil. Impressão 3D de Concreto. Métodos Construtivos. 


\section{INTRODUÇÃO}

Atualmente, a maior parte da produção em indústrias é automatizada. No entanto, segundo Porto (2016) o setor construtivo brasileiro ainda é atrasado tecnologicamente, quando comparado a países como China e EUA. Para a execução de grande parte das obras, ainda é necessária a mão-de-obra braçal para os métodos construtivos tradicionais de alvenaria. 0 uso desses métodos de longa data são as principais causas dos impactos ambientais e socioeconômicos gerados por essa indústria.

Nas últimas décadas, estudos sobre inovações tecnológicas na construção civil têm sido conduzidos abordando a produtividade e meio ambiente. A padronização dos processos manufatureiros e o controle de qualidade permitem elevado ganho de eficiência e ótimos resultados

Seguindo este raciocínio, estuda-se a viabilidade da construção de edificações por meio de impressão 3D. Esta tecnologia vem se desenvolvendo desde meados de 1980, a partir da prototipagem rápida. Segundo a The National Research Council, (2014) o processo consiste basicamente na sobreposição de camadas, de um dado material, até se obter o produto final.

Em 1998 surgiu o primeiro método voltado ao setor da construção civil, o "Contour Crafting”. Desde então, outras impressoras de concreto surgiram, e vêm sendo aprimoradas; diante dos fatos, empresas de fora do Brasil já conseguem edificar a partir desse processo, despertando a atenção de empresas brasileiras. Nesse setor, a impressão 3D permite a customização em massa e a produção de formas complexas, aliando redução de custos, prazos e da quantidade de resíduos gerados.

É necessária uma revisão crítica do método de impressão 3D de concreto e do seu desenvolvimento na construção civil brasileira, promovendo assim maior conhecimento à academia e à sociedade acerca desse processo.

Este trabalho tem como objetivo analisar a tecnologia de impressão 3D de concreto, identificando suas aplicações, reconhecendo as principais barreiras para o uso da tecnologia e, avaliando os benefícios que justificam a aplicação dessa inovação no setor da construção civil no Brasil.

\section{METODOLOGIA}

A pesquisa foi desenvolvida inicialmente do tipo bibliográfica, a qual, segundo Lakatos e Marconi, (2003) abrange toda bibliografia já tornada pública em relação ao tema de estudo, oferecendo, ao pesquisador, meios para definir um problema e resolvê-lo, ou para explorar novas áreas. Para complementar o caráter científico foi necessário também o desenvolvimento de um estudo de caso de teor exploratório, por coletar dados sobre o problema pesquisado com a intenção de se obter maior familiaridade com o tema.

o estudo de caso auxilia na percepção dos processos organizacionais do objeto de estudo e suas individualidades. 0 fato de ser de teor exploratório quer dizer que objetiva, por meio de formulação de questões, desenvolver hipóteses, aumentar a familiaridade com o objeto de estudo e fornecer embasamento para futuras pesquisas mais precisas ou esclarecer conceitos (LAKATOS e MARCONI, 2003).

O método de pesquisa utilizado foi o indutivo que, segundo Prodanov e Freitas (2013, p. 28), “[...] no raciocínio indutivo, a generalização deriva de observações de casos da realidade concreta. As constatações particulares levam à elaboração de generalizações".

\section{1 ÁREA DE ESTUDO}

A área de estudo abrange duas Startups que atuam no desenvolvimento de máquinas impressoras de concreto que responderam o questionário que caracteriza os principais aspectos da inovação, relacionando aplicações e benefícios, bem como identificando os principais pontos a serem superados para uma implantação mais sólida da tecnologia no mercado da construção civil brasileira.

As empresas estão localizadas em Brasília/DF e no Rio Grande do Norte mais precisamente na cidade de Macaíba.

A primeira tem como razão social InovaHouse 3D. Seu endereço comercial é na Asa Norte Comércio Local Norte 315 BL D loja 48 - Brasília/DF, 70.297-400, nas coordenadas de latitude 15o 44'38.05” SUL e longitude 470 53' 43.55" OESTE (Figura 1) 
Figura 1 - Localização da InovaHouse 3D - Asa Norte em Brasília/DF.

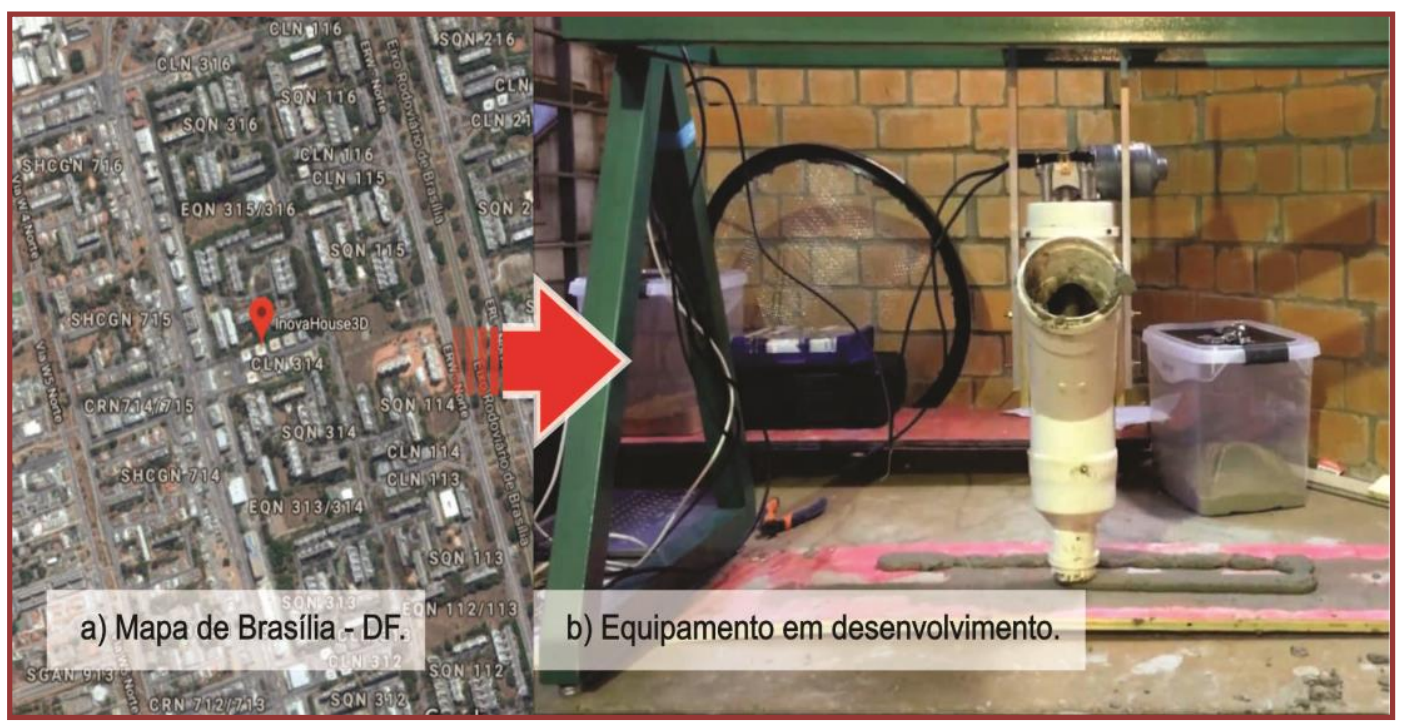

Fonte: Google Maps (Abril/2018) / http://inovahouse3d.com.br/ (2018).

A segunda tem com razão social 3D Home Construction, em desenvolvimento desde 2017, está localizada na Rua Projetada, S/N, Distrito Industrial, 59.280-000, Lote 0278, Setor-04, Quadra 0058, Galpão 5, Macaíba/RN. (Figura 2).

Figura 2 - Localização da cidade Macaíba-RN, localização da 3D Home Construction.

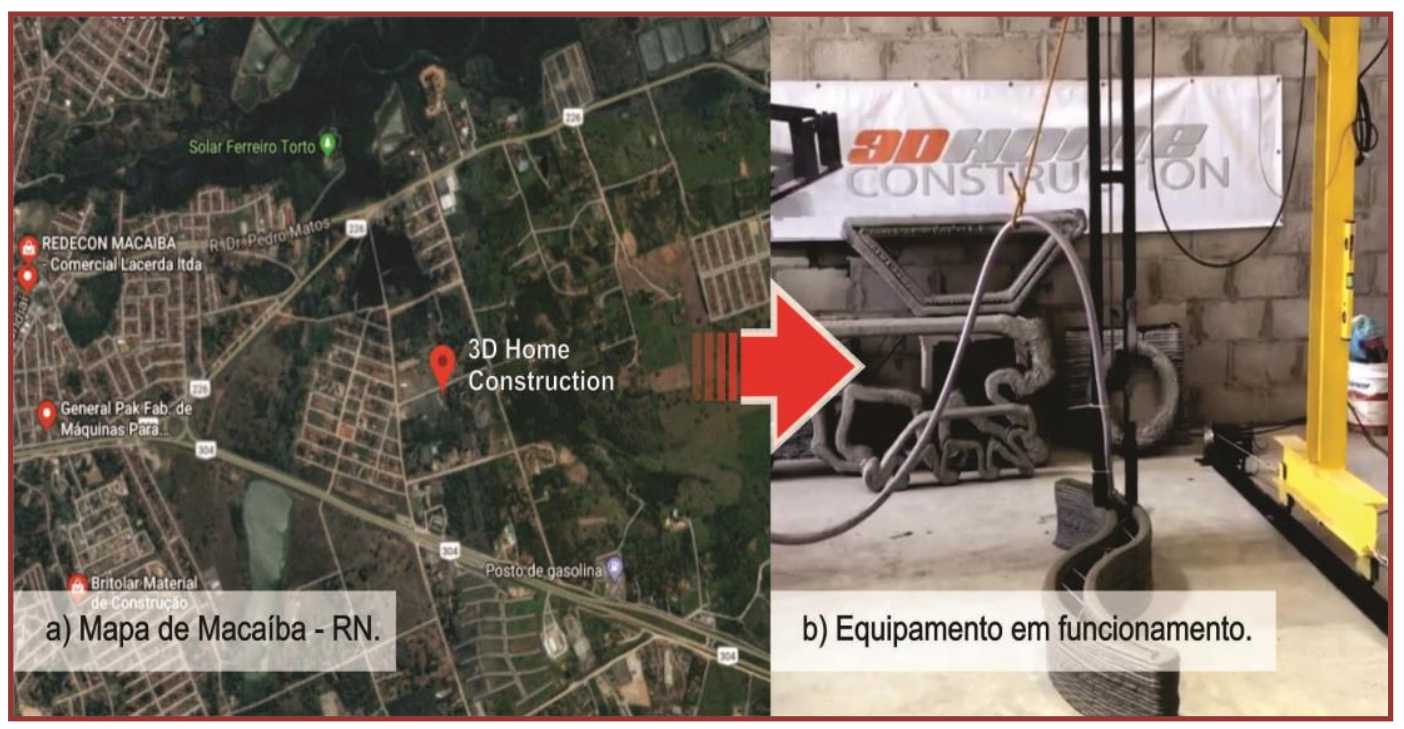

Fonte: Google Maps (Abril/2018) / https://iagofelipe1.wixsite.com/3dhomeconstruction

\subsection{COLETA DE DADOS}

A coleta de dados decorreu por meio de um questionário. 0 mesmo foi elaborado de modo a facilitar o fornecimento de dados imparciais e autênticos. Através dos resultados extraídos foi possível fazer uma correlação com os pontos propostos nos objetivos deste trabalho.

A pesquisa, composta apenas por questões fechadas, foi aplicada em uma amostra que corresponde a aproximadamente $66 \%$ do total de iniciativas que atuam no desenvolvimento e aplicação dessa tecnologia no setor construtivo.

A coleta de dados teve como finalidade revelar as condições de desenvolvimento dessa tecnologia no Brasil de acordo com suas vantagens e entraves de aplicação. 


\subsection{ANÁLISE DE DADOS}

A coleta dos dados possibilitou a análise qualitativa, apoiando-se em técnicas também quantitativas, onde foram obtidos dados descritivos que expressam os sentidos dos fenômenos. Todas as informações reunidas foram analisadas e comparadas, apresentadas através de tabelas e gráficos.

\section{RESULTADOS E DISCUSSÃO}

\subsection{APLICAÇõES DA IMPRESSÃO 3D NA CONSTRUÇÃO CIVIL}

Os resultados apresentados a seguir estão relacionados com as principais aplicações da impressão 3D na construção civil e sua demanda. As questões de 1 a 5 evidenciam os principais tipos de estruturas fabricadas. Percebe-se que $100 \%$ das empresas pesquisadas fazem uso da tecnologia para a construção de paredes. E apenas $50 \%$ utiliza a tecnologia para a manufatura de peças pré-fabricas e pré-moldadas, conforme as (Figuras 3; 4).

Figura 3 - Principais estruturas fabricadas a partir da impressão 3D.

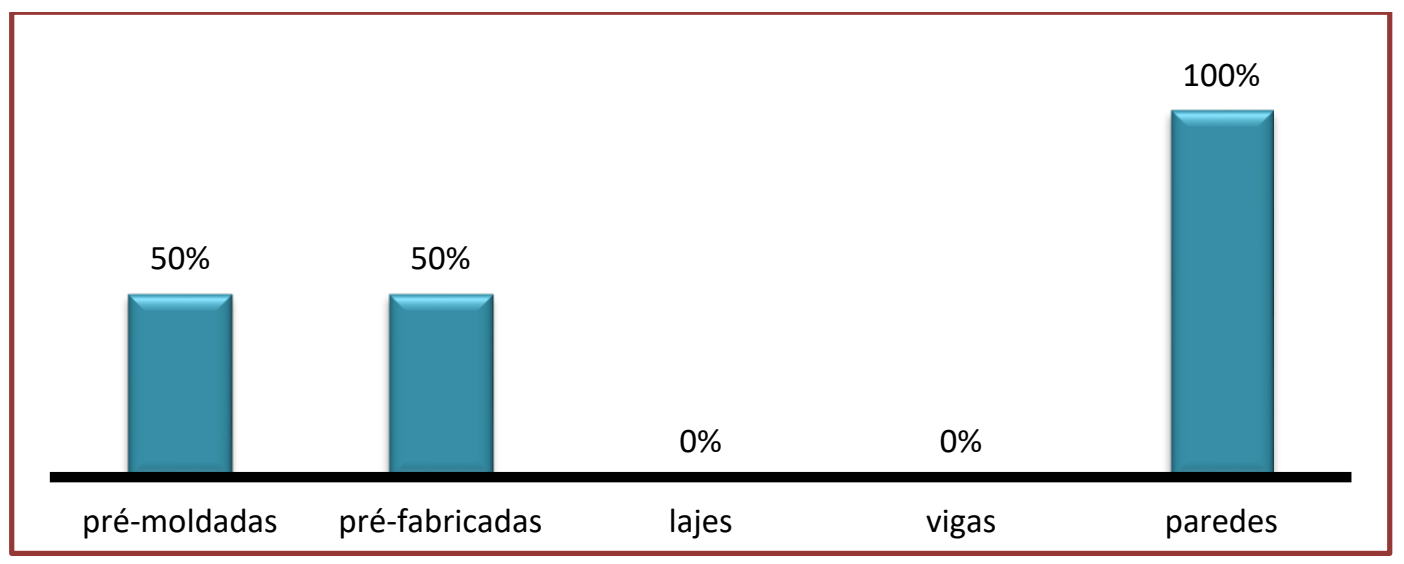

Fonte: Dados levantados na pesquisa de campo pela autora, maio/2018.

Evidencia-se também que não há uso da impressão 3D para a construção de peças estruturais como lajes e vigas dentre as empresas pesquisadas.

Figura 4 - Peças pré-fabricadas pela 3D Home Construction.

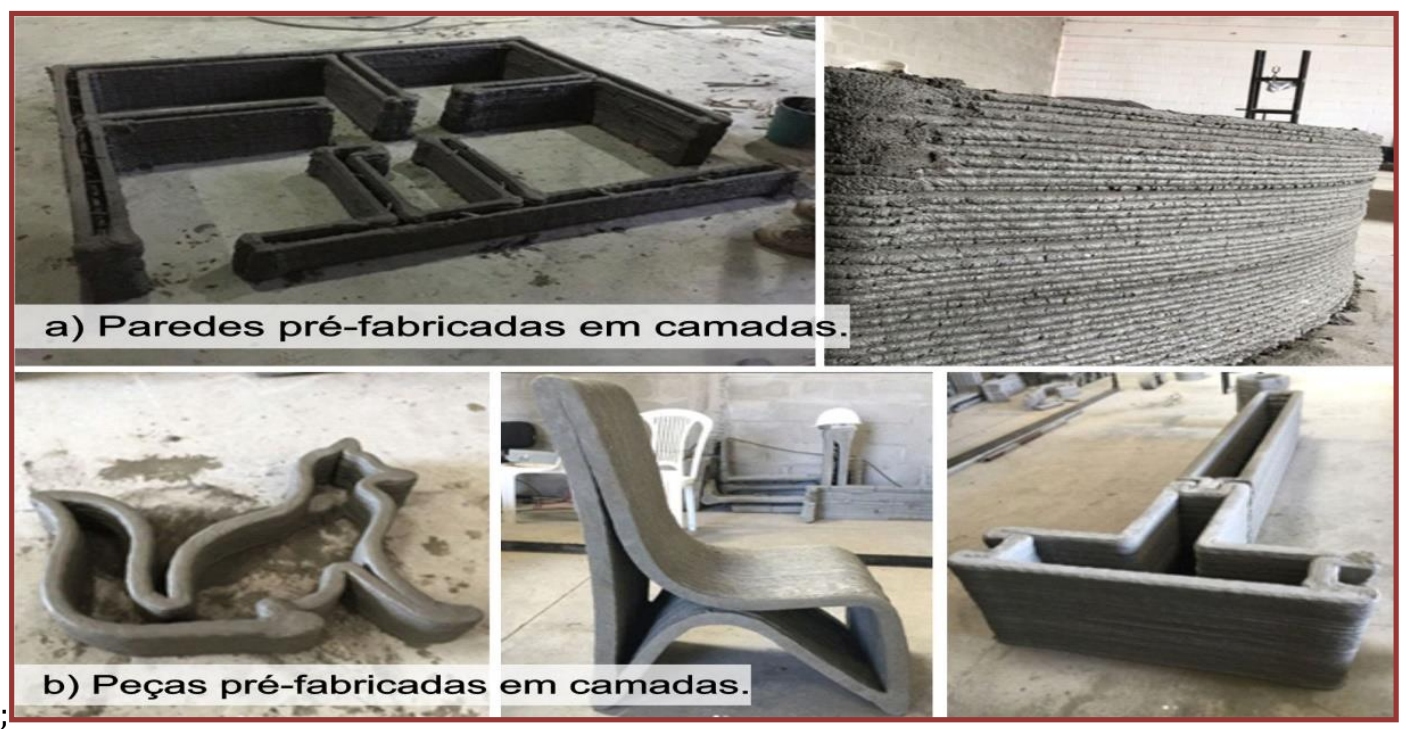

Fonte: Acervo 3D Home Construction, maio/2018. 
No âmbito de produção, a tecnologia é empregada para dois tipos de peças: a) pré-fabricadas fora do canteiro b) produzidas no canteiro. As peças pré-fabricadas podem ser para uso específico ou para módulos e paredes pré-moldadas. No caso das produzidas no canteiro, são comumente aplicadas na construção integral das paredes da edificação, por meio de uma impressora em dimensões que atendam os requisitos para essa fabricação (LOPES, 2016).

Ainda segundo Lopes (2016) as iniciativas fora do Brasil que desenvolveram suas tecnologias para a construção de paredes optaram pelo preenchimento do núcleo por outros materiais que agregam propriedades, conferindo maior estabilidade e resistência. Pode-se produzir um padrão de reforço interno, com espaço para tubulações, conduítes, materiais de isolamento térmico e reforço com barras de aço, como fez a empresa chinesa Winsun em suas peças (Figura 5).

Figura 5 - Paredes estruturais com espaço para tubulações e barras de aço.
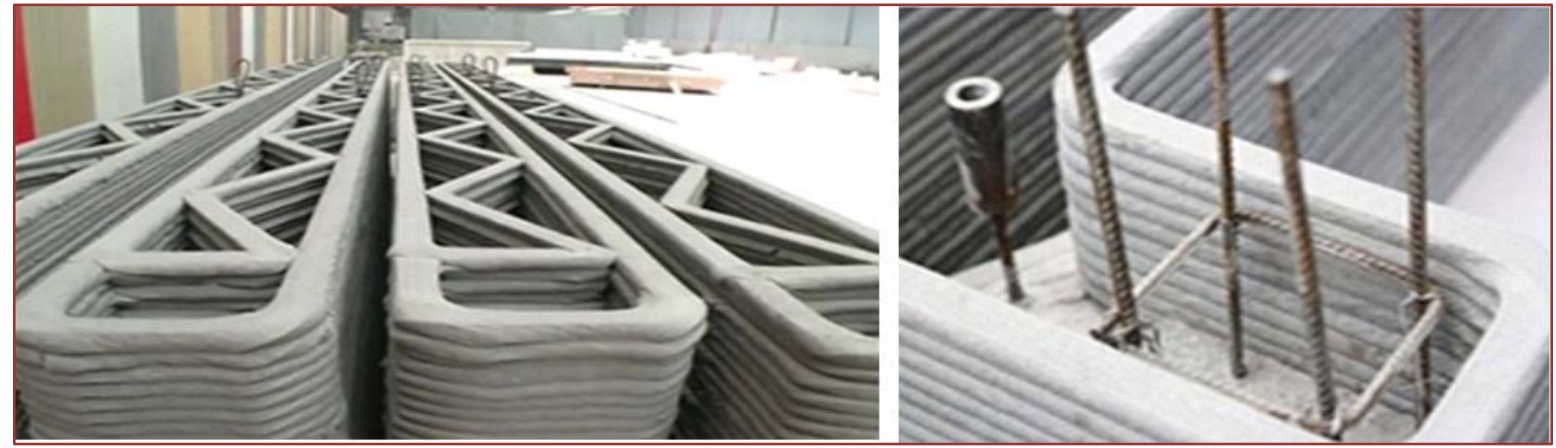

Fonte: http://www.winsun3d.com/En/About/, 2018

Considerando as questões de 6 a 8, que tratam da demanda de impressão 3D por tipo de edificação, observa-se que $50 \%$ das empresas afirma existir demanda tanto para edificações verticais e horizontais, como para obras especiais, ao tempo que 50\% afirma ainda não haver demanda no Brasil para nenhum dos tipos de edificação.

Analisando as respostas referentes às perguntas 9 e 10, sobre a demanda por caracterização da edificação, $100 \%$ das empresas concordam que a principal demanda é voltada para edificações do tipo residencial, portanto 0\% para edificações do tipo comercial, como mostrado no (Quadro 1).

Quadro 1: Demanda por caracterização da edificação.

\begin{tabular}{|c|c|c|}
\hline $\begin{array}{c}\text { Demanda por caracterização da } \\
\text { edificação }\end{array}$ & InovaHouse 3D & 3D Home Construction \\
\hline Comercial & NÃO & NÃO \\
\hline Residencial & SIM & SIM \\
\hline
\end{tabular}

Fonte: Dados levantados na pesquisa de campo pela autora, maio/2018.

Em suas pesquisas Khoshnevis et. al (2000) afirma que a principal e mais importante aplicação da tecnologia de impressão 3D está em âmbito residencial. No entanto, não descarta a fabricação de grandes obras públicas e comerciais. 0 próprio autor apresenta como plano de atuação o desenvolvimento da tecnologia para a construção de hospitais, escolas e prédios públicos, por exemplo. (KHOSHNEVIS, 2004)

\subsection{PRINCIPAIS BARREIRAS PARA O USO DA IMPRESSÃO 3D NA CONSTRUÇÃO CIVIL}

Os resultados desta seção estão relacionados às principais dificuldades enfrentadas para 0 desenvolvimento e difusão das tecnologias de impressão 3D no setor da construção civil. Tais fatos foram abordados nas perguntas de 11 a 24 no questionário aplicado.

A pergunta 11 trata da opinião das empresas em relação ao atual cenário de da tecnologia no país. A análise às respostas revela que 100\% das empresas consideram como mal o nível de difusão da tecnologia com foco no setor construtivo. 
Em 2007 O Programa de Inovação Tecnológica (PIT), promoveu oficinas que identificaram entraves para a implantação de inovações no setor construtivo brasileiro. Os mais visíveis foram: a distância entre a academia e o mercado consumidor, a distância entre a academia e o setor público, e o conservadorismo dos agentes do setor.

Esses entraves caracterizam-se pela dificuldade de relação entre setores, falhas nos mecanismos de difusão do conhecimento gerado pela academia e falta de fomento das empresas às pesquisas e ao desenvolvimento de inovações (ANTAC e CBIC, 2013).

As questões de 13 a 16 relacionam as principais dificuldades encontradas no desenvolvimento das impressoras de cada empresa. As respostas mostram que $100 \%$ das empresas consideram o alto investimento inicial, o controle da dosagem da mistura e o controle das características da máquina como barreiras que enfrentadas no desenvolvimento das suas tecnologias.

Já em relação ao desconhecimento tecnologia de impressão de concreto por parte do público brasileiro (Figura 6), 50\% da amostra considera como entrave para ascensão da tecnologia.

Figura 6 - Dificuldades encontradas no desenvolvimento e aplicação da tecnologia no setor construtivo brasileiro.

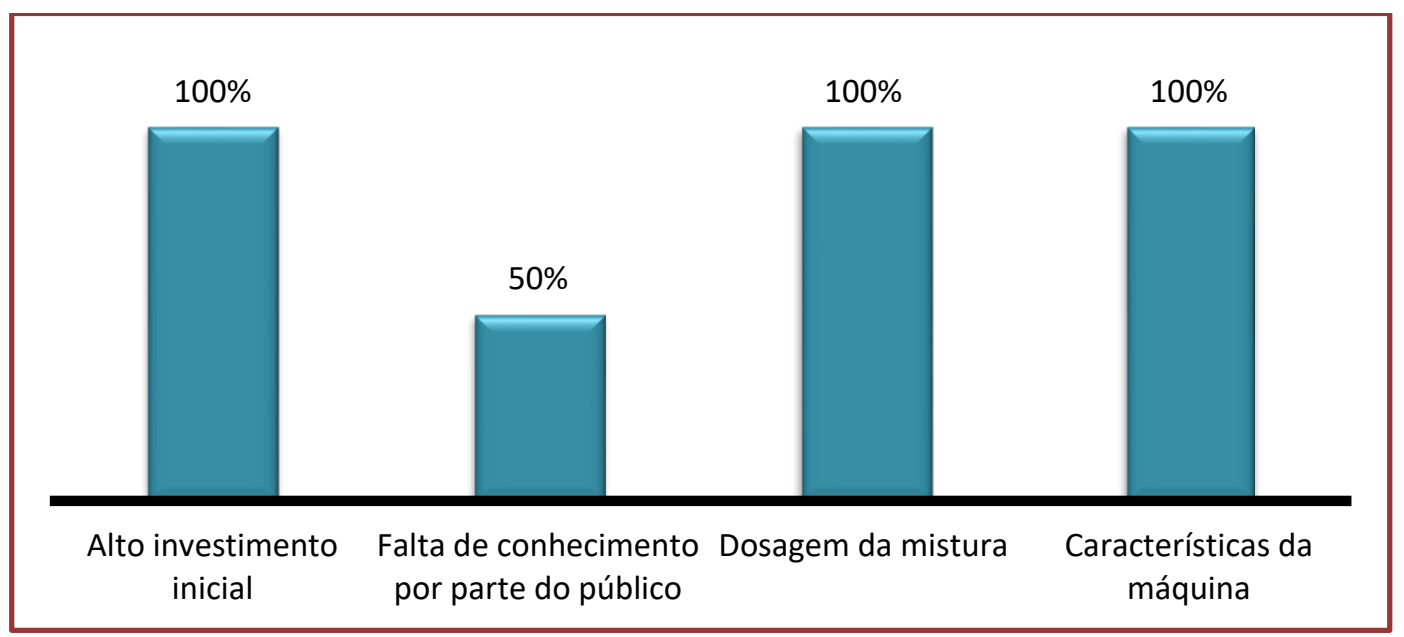

Fonte: Dados levantados na pesquisa de campo pela autora, maio/2018.

Correa (2016), que estuda especificamente o desenvolvimento da tecnologia em uma das empresas questionadas neste trabalho, afirma que mais de $50 \%$ das despesas com o produto é comprometida durante o planejamento e projeto conceitual, os quais envolvem análise de mercado, estudos de viabilidade, exigências do projeto e criação do produto.

Lieyun (2014) conclui em suas pesquisas que dentre os aspectos que mais impedem o desenvolvimento e a consolidação da impressão 3D de concreto estão: os materiais utilizados na impressão e sua devida dosagem, a efetividade, precisão, e dimensões do maquinário, como também o desenvolvimento de um algoritmo para o maquinário que mescle o devido atendimento às necessidades do processo produtivo às características do material. Pois assim, como preconiza Lim et al (2011) a maior dificuldade encontrada por ele está relacionada à introdução do material no maquinário e seu bombeamento até a extrusão.

0 fato de ter sido encontrada uma vasta gama de artigos e pesquisas abordando a dosagem e otimização de misturas para uso na impressão 3D de concreto nos mostra a dificuldade de se chegar a um traço específico, até porque BOS et al (2016) expõe que a depender do tipo de peça a ser fabricada, as características da mistura variam.

Quando perguntado sobre incentivo governamental para o desenvolvimento dos produtos das empresas pesquisadas $50 \%$ da amostra respondeu ter havido incentivo governamental, e 50\% respondeu que não houve.

ANTAC e CBIC (2013) expõem que falta formação de sociedade e parcerias entre a cadeia e o setor público para a implementação de inovações tecnológicas no setor construtivo. É muito reduzida a integração de universidades e empresas em desenvolvimento com entidades de fomento às pesquisas. Além disso, 
faltam parques tecnológicos voltados a esse setor. Esses fatores culminam em um baixo índice de financiamento que é disponibilizado para estes fins.

Uma medida indicada no relatório citado acima para sanar essa deficiência seria o lançamento de editais de pesquisa, promovendo o fomento a projetos de pesquisa. Foi a parti desses editais que uma das empresas pesquisadas recebeu cerca de R\$ 800 mil de incentivo governamental para desenvolver seu projeto. Além disso, a empresa foi selecionada para participar de um programa de aceleração.

Em relação às peças do maquinário, 100\% das empresas utilizaram peças de fornecedores nacionais ou fabricadas pela própria empresa. Os mesmos 100\% afirmam também não terem enfrentado como dificuldade a necessidade de importação de peças (Quadro 2).

Quadro 2: Origem de peças utilizadas no maquinário.

\begin{tabular}{cc|c} 
Peças para o maquinário & InovaHouse 3D & 3D Home Construction \\
Nacionais & SIM & SIM \\
Desenvolvidas pela própria empresa & SIM & SIM \\
\hline
\end{tabular}

Fonte: Dados levantados na pesquisa de campo pela autora, maio/2018.

Em se tratando dos softwares (Quadro 3), 100\% da amostra afirma não haver softwares nacionais que atendam às suas necessidades, assim como 100\% afirma que não houve desenvolvimento de softwares próprios pela empresa, culminando na utilização de softwares exclusivamente internacionais na impressão 3D de concreto.

Quadro 3: Utilização de softwares no processo de impressão.

\begin{tabular}{c|c|c|} 
Softwares utilizados na impressão & InovaHouse 3D & 3D Home Construction \\
Nacionais & NÃO & NÃO \\
Desenvolvidos pela própria empresa & NÃO & NÃO \\
\hline
\end{tabular}

Fonte: Dados levantados na pesquisa de campo pela autora, maio/2018.

Correa (2016) afirma que a quantidade de softwares com interface compatível à impressão de polímeros e ao padrão de arquivo STL é muito maior quando comparada àqueles compatíveis com a modelagem para impressão de concreto e arquivos IFC. Em seu estudo de viabilidade de desenvolvimento do produto são apontados como opções viáveis de softwares tanto de trajeto como de produção da peça: Slicer, Sfact, Skeinforge, Replicator G, RepSnapper e Repetier. Sendo todos eles softwares de origem estrangeira.

Ainda em suas pesquisas, a autora supracitada deixa claro que em todo o projeto de criação da impressora de concreto, buscou-se utilizar materiais de baixo custo e fácil aquisição. Sendo toda a montagem feita pela própria equipe (Figura 7;8).

Figura 7 - Maquinário desenvolvido pela 3D Home Construction.

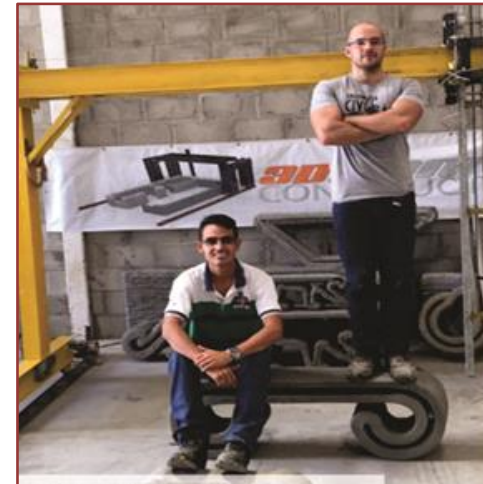

a) Pórtico metálico.

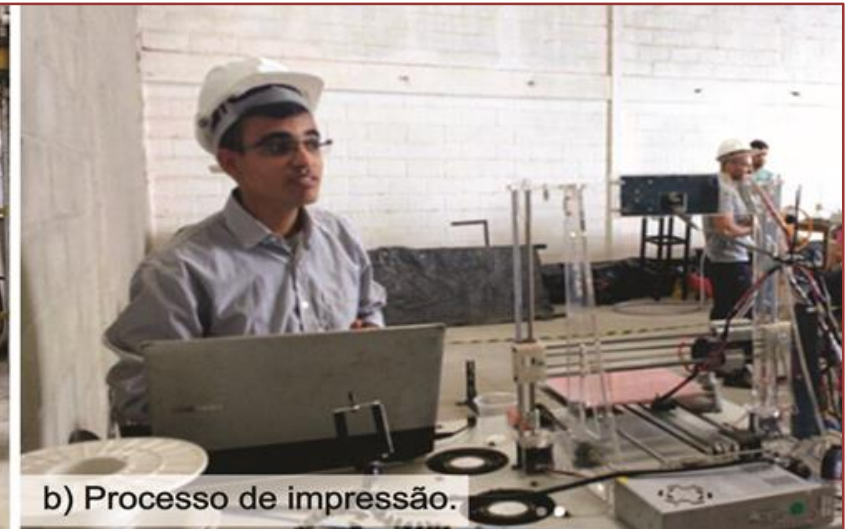

b) Processo de impressão.

Fonte: Acervo 3D Home Construction, maio/2018. 
Figura 8 - Peças do maquinário desenvolvido pela InovaHouse 3D.

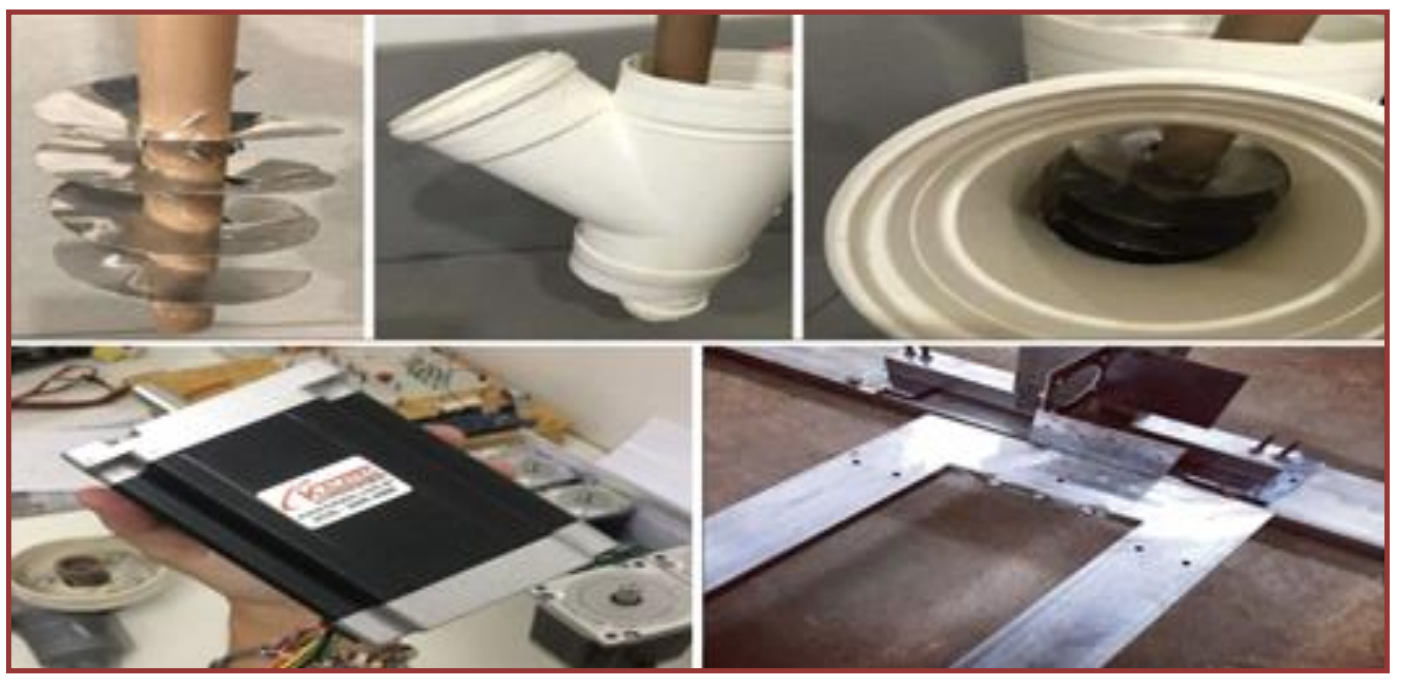

Fonte: Acervo InovaHouse 3D, maio/2018.

As questões 23 e 24 tratam das características da mão-de-obra comparadas a métodos construtivos convencionais. Em relação à qualificação, $100 \%$ das empresas concordam que é maior que a utilizada em métodos construtivos convencionais, já em relação à quantidade, $100 \%$ da amostra afirma ser igual ou menor que a utilizada em métodos convencionais (Figura 9).

Figura 9 - Características em relação à mão-de-obra.

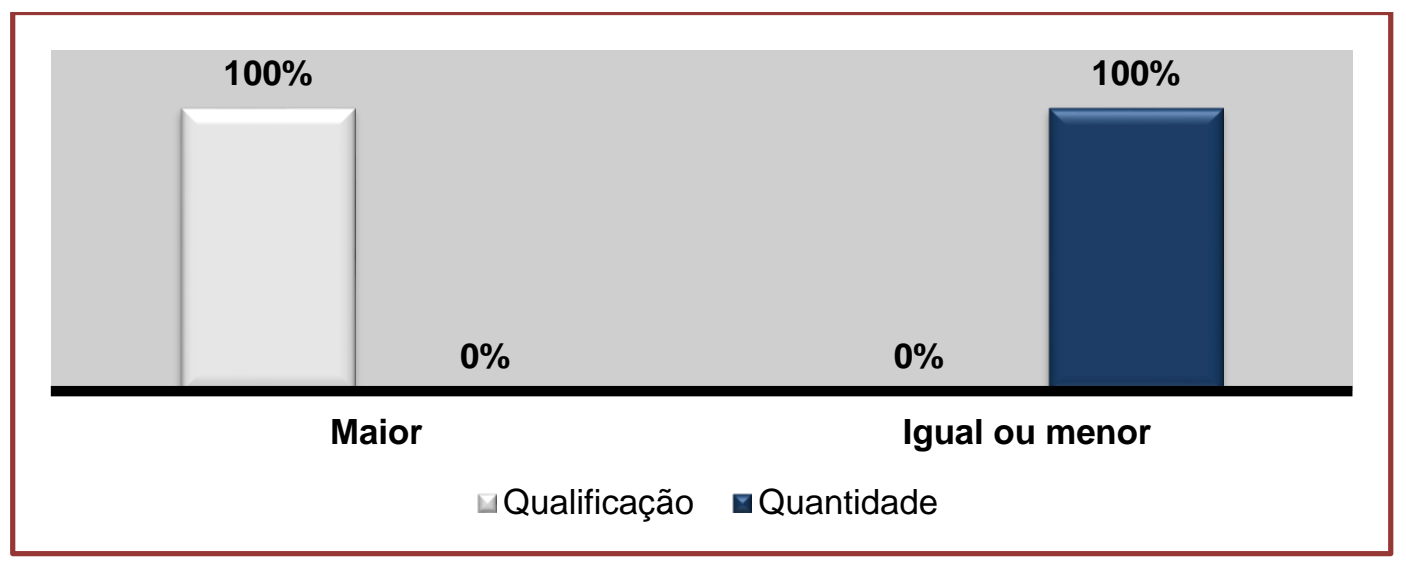

Fonte: Dados levantados na pesquisa de campo pela autora, maio/2018.

O desenvolvimento e a implantação de um novo método construtivo passam por adaptações e entraves iniciais, principalmente devido ao uso de longa data de métodos tradicionais. A implantação da impressão 3D no setor implicará na elevação da complexidade de processos, necessitando de mão-de-obra qualificada para operar o sistema (ANTAC e CBIC, 2013). Correa (2016) afirma que com o uso dessa tecnologia, haverá redução de mão-de-obra de até $50 \%$ quando comparado a métodos convencionais. Lopes (2016) trabalha na perspectiva de que a tecnologia permitirá redução dos custos com mão-de-obra em cerca de 40 a $60 \%$ do custo total da obra, já que reduzirá riscos relacionados à segurança e saúde do trabalhador. 


\subsection{BENEFÍCIOS QUE JUSTIFICAM A APLICAÇÃO DA IMPRESSÃO 3D NA CONSTRUÇÃO CIVIL}

A presente seção está associada aos principais benefícios da aplicação desta tecnologia na construção civil quando comparada aos métodos construtivos convencionais. As questões de 25 a 32 estão relacionadas com esta seção.

As questões 27, 30, 31 e 32 apresentam as vantagens mais relevantes indicadas pelas empresas pesquisadas. Das respostas é possível depreender que 100\% das empresas consideram como principais benefícios de aplicação da impressão 3D na construção civil: produção de residências padronizadas, redução de desperdício de materiais e no prazo da obra e, liberdade geométrica de peças. (Figura 10)

Figura 10 - Principais benefícios da impressão 3D em relação a métodos construtivos convencionais.

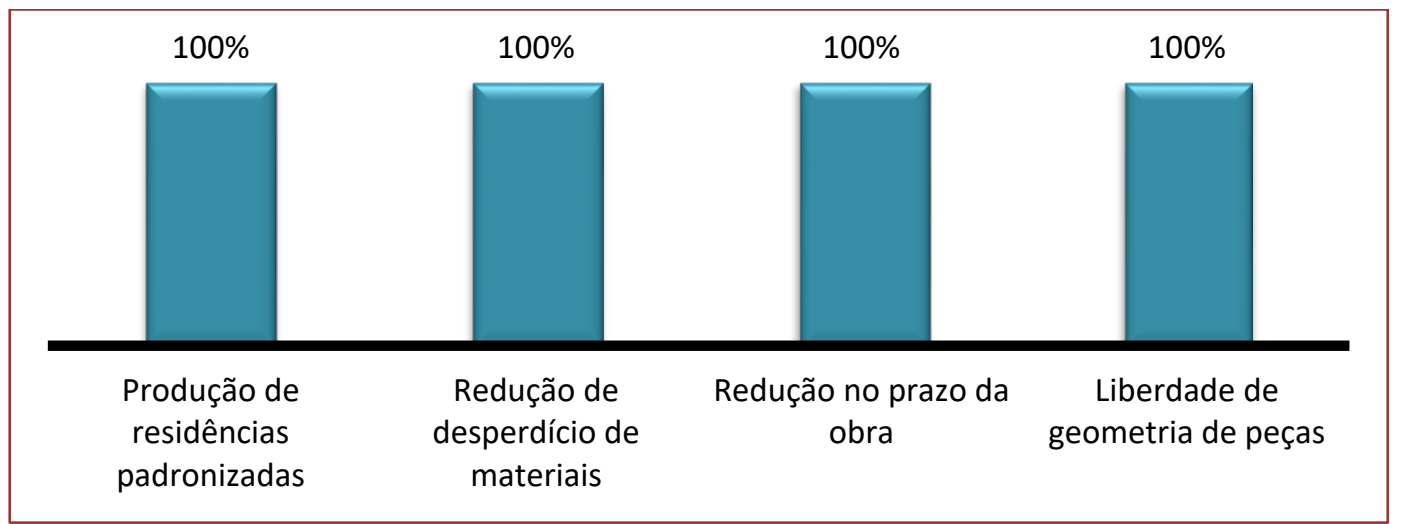

Fonte: Dados levantados na pesquisa de campo pela autora, maio/2018.

Os métodos construtivos convencionais apresentam custo elevado devido à variedade e quantidade de mão-de-obra atuante em um mesmo procedimento. Alguns dos fatores que contribuem para o alto custo do produto final são: alto índice de desperdícios dos materiais de construção e ausência de mão-de-obra qualificada. (SANTOS, 1998). O setor construtivo apresenta um índice de desperdício total de insumos em torno de 30\% do custo total de uma edificação. (PINTO, 1995). Tal fato instiga a busca por novos métodos construtivos que sanem esses problemas.

Quando perguntadas sobre a porcentagem aproximada da redução de desperdício de materiais e redução no prazo da obra foram obtidas as seguintes respostas de acordo com o (Quadro 4).

Quadro 4: Porcentagens de redução.

\begin{tabular}{|c|c|c|c|c|}
\hline & \multicolumn{2}{c}{ InovaHouse 3D } & \multicolumn{2}{c|}{ 3D Home Construction } \\
\cline { 2 - 5 } Fatores & Prazo & Desperdício & Prazo & Desperdício \\
Menor que $25 \%$ & & $\mathrm{X}$ & $\mathrm{X}$ & $\mathrm{X}$ \\
\hline Entre 25 e $50 \%$ & & & & \\
Maior que $50 \%$ & $\mathrm{X}$ & & & \\
\hline
\end{tabular}

Fonte: Dados levantados na pesquisa de campo pela autora, maio/2018.

Yossef e Chen (2015) preconizam em suas pesquisas que a utilização da impressão 3D na construção propicia a produção de peças em massa, utilizando menos mão-de-obra, a uma elevada velocidade de execução, com baixíssima geração de resíduos. Isso proporciona estruturas muito mais baratas devido ao custo geral de produção. Khoshnevis, (2004) reitera os fatos descritos acima com a seguinte (Quadro 5). 
Quadro 5: Economias da impressão 3D em relação à construção convencional.

\begin{tabular}{|c|c|c|}
\hline Economia (\%) & Fatores & Vantagens da utilização \\
\hline $20-25 \%$ & Financiamento & $\begin{array}{l}\text { Baixa duração de projeto e maior controle do } \\
\text { tempo de execução. }\end{array}$ \\
\hline $25-30 \%$ & Materiais & Sem desperdício na construção \\
\hline $45-55 \%$ & Mão-De-Obra & $\begin{array}{l}\text { Bastante reduzida. Trabalho braçal reduzido } \\
\text { por trabalho intelectual. }\end{array}$ \\
\hline
\end{tabular}

Fonte: Khoshnevis (2004).

Com relação aos custos da mistura e da área de edificação construída, as respostas ao último bloco de perguntas desta seção, que correspondem às questões $25,26,28$ e 29 , permitem compreender que $50 \%$ da amostra questionada afirma que o custo por $\mathrm{m}^{3}$ da mistura utilizada no seu processo de impressão de concreto é maior que o custo da mistura utilizada em métodos convencionais, já os demais $50 \%$ afirma que o custo por $\mathrm{m}^{3}$ da sua mistura é menor que o da mistura produzida em métodos convencionais. Em relação ao custo por $\mathrm{m}^{2}$ da edificação construída por impressão 3D, 100\% das empresas afirma ser menor que o custo por $\mathrm{m}^{2}$ de uma edificação construída por métodos convencionais (Figura 11).

Figura 11 - Comparação de custo em relação a métodos construtivos convencionais.

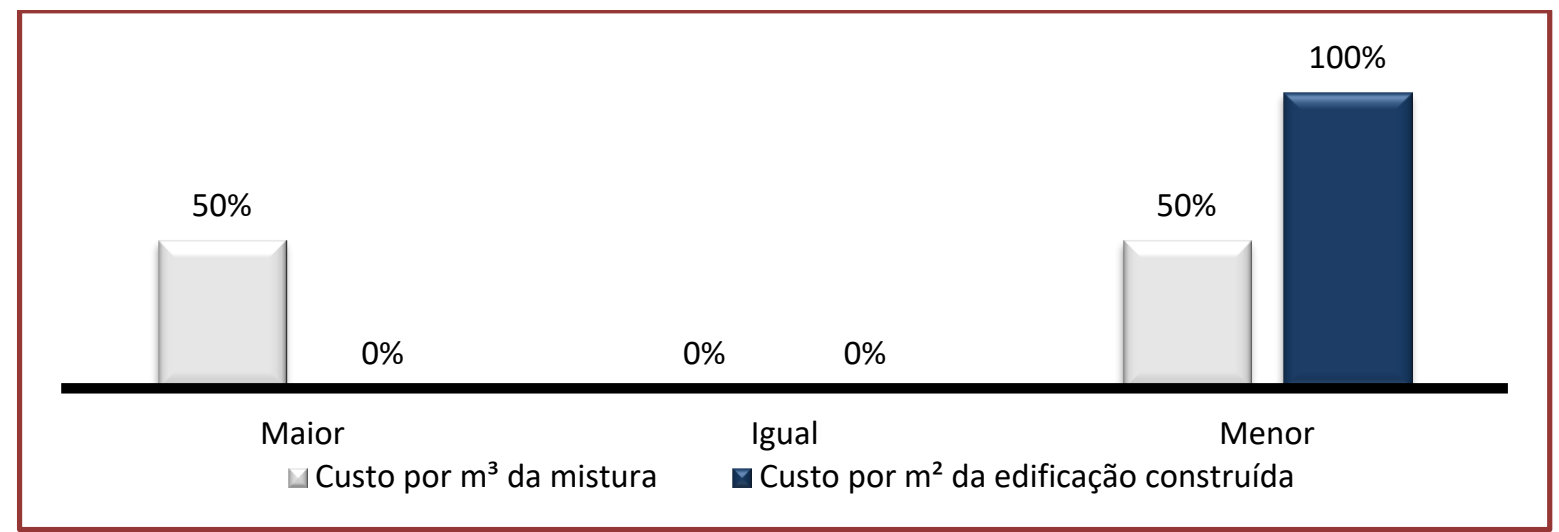

Fonte: Dados levantados na pesquisa de campo pela autora, maio/2018.

Muitos estudos têm sido conduzidos com foco na produção de misturas que façam uso de materiais provenientes da própria construção, possibilitando a redução do custo da mistura. (LOPES, 2016). Liang e Liang (2014) sugerem usar uma boa quantidade de resíduos e materiais reciclados, não deixando no entanto de atender as características necessárias, como resistência e trabalhabilidade, pois é questionável relacionar uma diminuição no custo da mistura com o uso de cimento de alta qualidade. (BOS et al, 2016)

0 custo por metro quadrado da edificação citado neste bloco está relacionado aos elementos horizontais e verticais pré-fabricados ou produzidos in loco, ou seja, relaciona-se com os materiais utilizados, prováveis desperdícios, quantidade e qualidade de mão-de-obra utilizada e prazos. Em uma entrevista concedida, uma das empresas afirmou que a partir de estudos feitos, a previsão é de que o preço do metro quadrado seja $40 \%$ menor em relação a métodos convencionais.

Os dados obtidos a partir do catálogo da empresa Russa ApisCor corrobora com as respostas obtidas apresentando os seguintes resultados obtidos através do seu método de impressão conforme (Quadro 6). 
Quadro 6: Comparação de custos e prazos de métodos construtivos convencionais com o método de impressão da ApiCor.

\begin{tabular}{|c|c|c|}
\hline & Método convencional & Apiscor \\
\hline Logística do material & & 3.7 vezes menos \\
\hline $\begin{array}{l}\text { Material por } 1 \mathrm{~m}^{3} \text { de parede } \\
\text { construída }\end{array}$ & $1 \mathrm{~m}^{3}$ de blocos & $0.267 \mathrm{~m}^{3}$ de mistura impressa \\
\hline $\begin{array}{l}\text { Velocidade de construção, } 1 \mathrm{~m}^{3} \\
\text { de parede construída }\end{array}$ & 3.56 Homem-Hora & $\begin{array}{c}0.85 \text { Máquina-Hora, ou seja, a } \\
\text { velocidade aumenta quase } 6 \text { vezes. }\end{array}$ \\
\hline $\begin{array}{l}\text { Custo com } 1 \mathrm{~m}^{2} \text { de parede } \\
\text { construída }\end{array}$ & $\begin{array}{l}4445 \mathrm{P} \text { (rubles russos) } \approx \\
\mathrm{R} \$ 268,00 \text { (reais) }\end{array}$ & $\begin{array}{c}1556 \text { P (rubles russos) } \approx \mathrm{R} \$ 94,00 \\
\text { (reais), ou seja, redução de } 2.8 \text { vezes no } \\
\text { custo. }\end{array}$ \\
\hline
\end{tabular}

Fonte: ApisCor, Company Presentation (2018).

\section{CONSIDERAÇÕES FINAIS}

O presente trabalho identificou as aplicações e benefícios da impressão 3D na construção civil, assim como os entraves a serem superados para sua implantação.

Os resultados evidenciaram que, $100 \%$ das empresas pesquisadas utilizam a impressão de concreto com foco na construção de paredes, e $50 \%$ na construção de peças pré-fabricadas não estruturais, com maior demanda de origem residencial. Em relação às dificuldades de desenvolvimento $50 \%$ das empresas considerou como entrave o desconhecimento do público brasileiro sobre esta tecnologia. Já em relação aos benefícios, $100 \%$ das empresas afirmou que o uso da impressão de concreto proporciona redução de custos, prazos, mão-de-obra e resíduos.

Portanto, em comparação ao método convencional, a tecnologia de impressão 3D de concreto apresentou algumas vantagens e desvantagens. As vantagens estão associadas à diminuição de $25 \%$ no custo total da obra, $50 \%$ na quantidade de mão-de-obra utilizada, $24 \%$ na velocidade de execução de $1 \mathrm{~m}^{3}$ de parede e $30 \%$ no desperdício de materiais. Outrossim, as desvantagens estão relacionadas à necessidade de mãode-obra com maior qualificação, de aquisição de softwares internacionais para o processo de impressão, ao rígido controle nas características da mistura e da máquina e ao alto investimento inicial necessário para o desenvolvimento do produto.

É importante frisar que desde o início de elaboração do trabalho foram procurados dados acerca do cadastro de Startups com foco no setor construtivo que trabalhassem com impressão 3D de concreto em diversas fontes como: CNAE, SEBRAE, CBIC, Start-Up Brasil, entre outras. No entanto, não foram encontradas informações consistentes para se chegar a dados concretos de amostragem.

Embora tenham um longo caminho a percorrer, as iniciativas em desenvolvimento de impressão 3D de concreto visam contribuir para a modernização da construção civil, aumentando produtividade, racionalização e padronização dos processos, aliados à sustentabilidade. A introdução dessa inovação pode levar o referido setor a um patamar de lucratividade produtiva e imobiliária até então não atingidos.

\section{REFERÊNCIAS}

[1] ASSOCIAÇÃO NACIONAL DE TECNOLOGIA DO AMBIENTE CONSTRUÍDO e CÂMARA BRASILEIRA DA INDÚSTRIA DA CONSTRUÇÃO. Estratégias para a formulação de Política de Ciência, Tecnologia e Inovação para a indústria da Construção Civil. Brasília: ANTAC e CBIC, 2013.

[2] CÂMARA BRASILEIRA DA CONSTRUÇÃO CIVIL. Catálogo de inovação na construção civil. Brasília: CBIC, 2016.

[3] NATIONAL RESEARCH COUNCIL. 3D Printing in Space. Washington, DC: The National Academies Press. 2014. doi: 10.17226/18871.

[4] APISCOR. ApisCor Company Presentation. Disponível em: <http://apiscor.com/files/ApisCor_presentation_en.pdf>. Acesso em: 05 março, 2018.

[5] BOS, F; WOLFS, R.; AHMED, Z.; SALET, T. Additive manufacturing of concrete in construction: potentials and challenges of 3D concrete printing. In: Virtual and Physical Prototyping Journal. 2016. v. 11, iss. 3, p. 209-225. 
[6] Correa, L. T. M. Manufatura Aditiva como Princípio de Solução para Industrialização da Construção Civil. Trabalho de Conclusão de Curso. Brasília: FT/UnB - Universidade de Brasília. Faculdade de Tecnologia, 2016.

[7] KHOSHNEVIS, B.; BUKKAPATNAM, S; KWON, H. Automated construction using contour crafting. Los Angeles, 2000.

[8] KHOSHNEVIS, B.; Houses of the future: Construction by contour crafting building houses for everyone. Los Angeles: University of Southern California, 2004.

[9] LAKATOS, E. M.; MARCONI, M. A. Fundamentos de metodologia científica. 5. ed. São Paulo: Atlas, 2003.

[10] LIANG, F.; LIANG, Y. Study on the status quo and problems of 3D printed buildings in China. In: Global Journal of Human-Social Science, 2014.

[11] LIEYUN, D.; RAN, W.; HAICHAOA, C. Development of a BIM-based automated construction system. In: Creative Construction Conference, 2014. p. 18-23.

[12] LIM, S.; BUSWELL, R.; LE, T.; WACKROW, R.; SIMON, A.; GIBB, A.; THORPE, T. Development of a viable concrete printing process. In: 28th International Symposium on Automation and Robotics in Construction - ISARC. Seoul, South Korea: IAARC, 2011. p. 665-670.

[13] LOPES, G. T. F. Exploração das possibilidades da impressão 3D na construção civil. Dissertação (Mestrado). Porto, Portugal: FEUP, 2016.

[14] PINTO, T. De volta à questão do desperdício. Construção. São Paulo, 1995. n.271, p.34-35.

[15] PORTO, T. M. S. Estudo dos avanços da tecnologia de impressão 3D e da sua aplicação na construção civil. Rio de Janeiro: UFRJ, 2016.

[16] PRODANOV, C. C.; FREITAS, E. C. Metodologia do trabalho científico [recurso eletrônico]: métodos e técnicas da pesquisa e do trabalho acadêmico. 2. ed. Novo Hamburgo: Feevale, 2013.

[17] SANTOS, M. D. F. D. Técnicas construtivas em alvenaria estrutural: contribuição ao uso. Santa Maria: UFSM, 1998.

[18] YOSSEF, M.; CHEN, A. Applicability and Limitations of 3D Printing for Civil Structures. Ames, IA: In: Proceedings of the 2015 Conference on Autonomous and Robotic Construction of Infrastructure, 2015. p. 237-246. 


\section{Capítulo 10}

Análise sobre a implantação de ferramentas de gestão de riscos em obras de edificações nos municípios de Aracaju e São Cristóvão/SE

Marcos Moran Oliveira da Silva

Sandro Iury Valverde Lima da cruz.

Resumo: Dentre tantos setores de trabalho a construção civil é um dos setores mais perigosos, pois o ambiente de trabalho contempla inúmeros fatores de riscos expondo seus trabalhadores diariamente a acidentes diversos, por essa razão, a segurança do trabalho nos canteiros de obras é fundamental para a integridade física, emocional e de saúde desses trabalhadores. Muito usados nas empresas como forma de prevenir os riscos de acidentes e mesmo tendo uma importância indiscutível, o uso dos EPI's e EPC's adequadamente em alguns momentos ainda são rejeitados pelo costume em achar que 0 sinistro não vai acontecer, ferindo assim, as normas que os regulam. Um sistema de antecipação que pode ser aplicado nos canteiros de obras é a gestão de riscos, que oferece ferramentas importantes e muito utilizadas em processos produtivos. Como exemplo de ferramenta, pode-se citar a Análise Preliminar de Perigos (APP). Partindo de tais pressupostos, o objetivo principal do presente trabalho é analisar a gestão de riscos em canteiros de obras nas cidades de Aracaju e São Cristóvão e propor implantação de ferramenta de gestão para demonstrar um melhor monitoramento dos agentes de risco que poderão causar acidentes de trabalho. A metodologia do mesmo se debruçou em uma pesquisa de cunho qualitativo, quantitativo e exploratório que apontou nas obras analisadas os riscos mais iminentes de acidentes de trabalho e para dar consistência ao que foi delineado, uma pesquisa bibliográfica foi necessária. Ao final da pesquisa observou-se que o uso da Análise Preliminar de Perigos (APP) teria uma resposta positiva no controle e diminuição de riscos e acidentes em virtude de nenhuma das empresas pesquisadas fazer uso de ferramentas de gestão.

Palavras-chave: Segurança do trabalho, acidentes de trabalho, gestão de riscos. 


\section{INTRODUÇÃO}

A construção civil é o setor de trabalho mais antigo e vem acompanhando a humanidade ao longo dos anos, evoluindo à medida do crescimento da população e suas necessidades.

Dentre tantos setores de trabalho a construção civil é um dos setores mais perigosos, pois o ambiente de trabalho contempla inúmeros fatores de riscos expondo seus trabalhadores diariamente a acidentes diversos, por essa razão, a segurança do trabalho nos canteiros de obras é fundamental para a integridade física, emocional e de saúde desses trabalhadores.

Os fatores de riscos presentes nos locais de trabalho são considerados como agentes insalubres ou periculosos, que em decorrência da falta de controle podem gerar lesões ou até perdas temporárias ou definitivas para as empresas e a sociedade trabalhadora do nosso país.

A preocupação em minimizar ou até mesmo eliminar esses agentes de riscos vem crescendo a cada ano desde que se observou a necessidade de melhorar as condições de trabalho, prevenindo acidentes e aumentando a produtividade, em função das necessidades de se evitar o absenteísmo, atraso no calendário da obra, custos com novas contratações devido aos afastamentos e outras despesas decorrentes deste infortúnio.

Nesse contexto, as organizações devem ter cuidados básicos essenciais com o controle dos riscos ao qual estão expostos seus trabalhadores, empenhando-se na percepção de riscos que são responsáveis por maior parte dos acidentes em uma obra. A falta de cultura prevencionista, comprometimento da alta gestão e das áreas operacionais dá-se pelo fator segurança x produtividade, onde, os responsáveis pelo processo construtivo veem a segurança como fator impeditivo para o cumprimento de metas.

Muito usados nas empresas como forma de prevenir os riscos de acidentes e mesmo tendo uma importância indiscutível, o uso dos EPI's e EPC's adequadamente em alguns momentos ainda são rejeitados pelo costume em achar que o sinistro não vai acontecer, ferindo assim, as normas que os regulam. Mesmo com o uso contínuo dos equipamentos de proteção individual e coletiva, a antecipação e prevenção de acidentes é uma das maneiras mais adequadas para eliminar ou reduzir os riscos na construção civil.

Um sistema de antecipação que pode ser aplicado nos canteiros de obras é a gestão de riscos, que oferece ferramentas importantes e muito utilizadas em processos produtivos. Como exemplo de ferramenta, a Análise Preliminar de Perigos (APP) é uma técnica dentro da gestão de riscos que poderá ser adotada para realizar uma análise qualitativa desde a fase de concepção até o desenvolvimento de um projeto ou atividade cuja experiência em riscos na sua operação seja deficiente.

Os investimentos em práticas diferenciadas de gestão trazem prevenção, mantendo os rendimentos das empresas de forma positiva, não alterando sua lucratividade.

0 desenvolvimento do presente estudo visa mostrar o cenário atual da construção civil demonstrando os fatores de riscos potenciais que podem trazer prejuízos aos trabalhadores e empregadores, tratando da necessidade de gerenciar os riscos por meio de técnicas e ferramentas de gestão, mostrando as dificuldades para implantação, e os benefícios que essas técnicas podem trazer. Oferecendo ainda como opção para construção civil uma das ferramentas que mais se encaixam no setor, a APP.

0 principal objetivo da pesquisa é analisar a gestão de riscos em canteiros de obras nos municípios de Aracaju e São Cristóvão e propor implantação de ferramenta de gestão para demonstrar um melhor monitoramento dos agentes de risco que poderão causar acidentes de trabalho.

\section{METODOLOGIA}

A metodologia desta pesquisa será distribuída em Caracterização da Área de Estudo, Coleta de dados e Análise de Dados. 
A Metodologia é a explicação minuciosa, detalhada, rigorosa e exata de toda ação desenvolvida no método (caminho) do trabalho de pesquisa. É a explicação do tipo de pesquisa, do instrumental utilizado (questionário, entrevista etc.), do tempo previsto, da equipe de pesquisadores e da divisão do trabalho, das formas de tabulação e tratamento dos dados, enfim, de tudo aquilo que se utilizou no trabalho de pesquisa.

\section{1 ÁREA DE ESTUDO}

Esta pesquisa está direcionada a prevenção de acidentes, dentro da Segurança e Saúde no Trabalho, especificamente na verificação de ocorrência de riscos e consequentemente na análise quanto ao uso de ferramentas de gestão em canteiros de obras situados nas cidades de Aracaju e São Cristóvão, ambos localizados no estado de Sergipe (Figura 3).

Em se tratando de Aracaju, a cidade ocupa uma área de unidade territorial de $181,857 \mathrm{Km}^{2}$ (2016) e conforme dados do último censo do IBGE (2010) conta com uma população de 571.149 habitantes e com uma densidade demográfica de 3.140,65 hab $/ \mathrm{km}^{2}$. Segundo a Lei no 554 de 06 de fevereiro de 1954-Anexo II publicado em 14.12.1954 D.o, o município de Aracaju, limita-se com os municípios de São Cristovão, Nossa Senhora do Socorro e Santo Amaro das Brotas.

Já São Cristóvão, a cidade ocupa uma área de $438,037 \mathrm{Km}^{2}$ e conforme dados do último censo do IBGE (2010) conta com uma população de 78.864 habitantes e com uma densidade demográfica de $180,52 \mathrm{hab} / \mathrm{km}^{2}$.

O primeiro empreendimento do estudo de caso será chamado de obra "A" e está localizado na Avenida Poeta Mário Jorge Menezes Vieira, Bairro Coroa do Meio - Aracaju/SE. A construção possui as seguintes coordenadas em UTM: Latitude (8889261) e Longitude (714552). A obra tem prazo de duração entre oito de janeiro de dois mil e dezoito a oito de junho de dois mil e dezoito e refere-se à reforma e ampliação de um hospital feito em estrutura mista (Concreto e perfis metálicos), fechamento externo em alvenaria de vedação, composto de quatro pavimentos, sendo um térreo e mais três pavimentos. Na ampliação da unidade, as atividades desenvolvidas serão concretagem de lajes, revestimentos (interno e externo), fachada, instalações elétrica e hidráulica, pintura, fôrro de gesso, divisórias dos ambientes em drywall, dentre outras. A área total do terreno é de $1.600 \mathrm{~m}^{2}$ e a área construída é de $2600 \mathrm{~m}^{2}$. A obra conta com efetivo atual de 68 trabalhadores.

O segundo empreendimento chamado de obra "B" está localizado na Avenida Oviêdo Teixeira, Bairro Jardins - Aracaju/SE. A construção possui as seguintes coordenadas em UTM: Latitude (8788786) e Longitude (712226). A obra teve início em primeiro de outubro de dois mil e dezesseis e tem prazo de término para trinta e um de julho de dois mil e dezenove. Refere-se à construção de um edifício residencial composto por uma torre de 15 pavimentos, sendo um pavimento térreo, um playground e 13 pavimentos tipo. A área total do terreno é de $3.641,85 \mathrm{~m}^{2}$ e a área construída é de $14.538,54 \mathrm{~m}^{2}$. A obra conta com efetivo atual de 118 trabalhadores.

O terceiro empreendimento, conhecido como obra "C" está situado a Rua Passos Cabral, Bairro Jardins Aracaju/SE. A construção possui as seguintes coordenadas em UTM: Latitude (8790657) e Longitude (712754). A obra teve início em quinze de fevereiro de dois mil e dezoito e tem término previsto para quinze de fevereiro de dois mil e vinte. Refere-se à construção de Edifício Residencial composto por uma torre de 14 pavimentos, sendo um térreo, um playground e 12 pavimentos tipo. A área total do terreno é de $2.038,38 \mathrm{~m}^{2}$ e a área construída é de $11.057,14 \mathrm{~m}^{2}$. A obra conta com um efetivo atual de 08 trabalhadores devido a sua fase inicial.

O quarto canteiro visitado será chamado de obra "D" e está situado a Av. Capitão Joaquim Martins Fontes, Bairro Farolândia - Aracaju/SE. A obra possui as seguintes coordenadas em UTM: Latitude (8787309) e Longitude (712581). A construção teve início em novembro de dois mil e quinze e a previsão para entrega será em dezembro de dois mil e dezoito.

0 empreendimento é feito em estrutura convencional de concreto armado e alvenaria de vedação. Consiste em uma construção de 02 torres com 17 pavimentos, sendo 01 térreo, 01 superior, 01 playground, 01 com 04 apartamentos e 13 pavimentos tipo com 04 apartamentos por andar, com um total de 108 apartamentos, 54 apartamentos por torre. A obra conta com efetivo atual de 70 trabalhadores.

A quinta obra chamada de obra "E" está situado a Avenida Querino, Bairro Inácio Barbosa - Aracaju/SE. 0 empreendimento possui as seguintes coordenadas em UTM: Latitude (8788308) e Longitude (710036). A construção teve início em março de dois mil e dezesseis e tem término previsto para março de dois mil e 
dezenove. 0 empreendimento é feito em alvenaria estrutural e conta com 5 torres residenciais, composto por 10 pavimentos cada, sendo 8 apartamentos por andar, totalizando 400 apartamentos. A área total do terreno é de 19.700,00 $\mathrm{m}^{2}$ e a área construída (torres + área comum) é de 24.992,56 $\mathrm{m}^{2}$. A obra conta com efetivo atual de 150 trabalhadores.

O sexto empreendimento visitado, conhecido como obra "F" está situado a Rua Estrada da Cabrita, Bairro Santa Lúcia - São Cristovão/SE. A obra possui as seguintes coordenadas em UTM: Latitude (8789888) e Longitude (708042). A construção teve início em primeiro de julho de dois mil e dezesseis e tem término previsto para trinta de setembro de dois mil e dezoito. Refere-se à Empreendimento Residencial multifamiliar constituído de 07 Torres, com térreo e mais seis pavimentos tipo, com 06 apartamentos por pavimento, totalizando 294 unidades residenciais.

A área do terreno é de $16.635 \mathrm{~m}^{2}$, sendo a área total construída com $23.860 \mathrm{~m}^{2}$. A obra é executada em alvenaria estrutural e sapata convencional e conta com efetivo atual de 210 trabalhadores.

O Sétimo empreendimento chamado de Obra "G" está localizado a rua projetada, lote $4 \mathrm{~b}$, entre a estrada da cabrita e a Rua Jasiel de Brito Côrtes, Bairro Santa Lúcia - São Cristovão/SE. A obra possui as seguintes coordenadas em UTM: Latitude (8790699) e Longitude (706134). A construção teve início em primeiro de abril de dois mil e dezessete e tem término previsto para trinta e um de julho de dois mil e dezenove.

Refere-se à construção de Condomínio residencial multifamiliar, elevado em alvenaria estrutural, formado por 08 blocos com 07 pavimentos cada, com 42 unidades por bloco, totalizando 336 unidades habitacionais padrão. A área do Terreno é de $16.734,67 \mathrm{~m}^{2}$ e a área construída é de $20.477,40 \mathrm{~m}^{2}$. A obra conta com efetivo atual de 139 trabalhadores.

Por meio da Figura 1 pode-se visualizar as áreas da pesquisa:

Figura 1: Mapa com a localização das cidades de Aracaju, São Cristóvão e das obras pesquisadas.

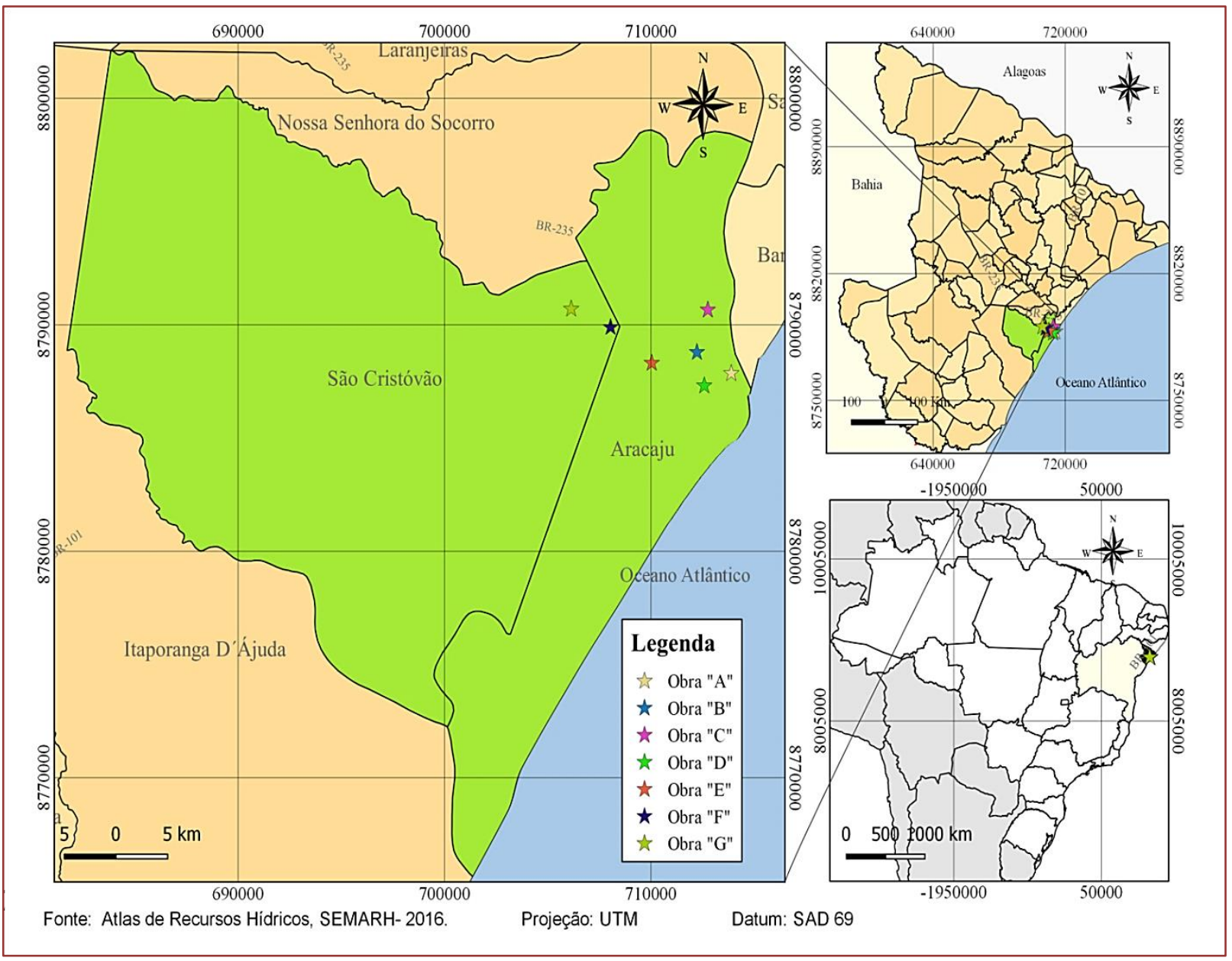




\subsection{COLETA DE DADOS}

Os dados da pesquisa foram coletados por meio de pesquisas bibliográficas em livros, artigos científicos, sites da internet, revistas, normas regulamentadoras, NBR's, visitas a órgãos oficiais como a Superintendência de Recursos Hídricos de Sergipe (SRH) e a Superintendência Regional do Trabalho e Emprego de Sergipe (SRTE-SE), além da aplicação de questionário semiestruturado aplicado por meio de visitas "in loco" aos canteiros de obras localizados no Estado de Sergipe especificamente nas cidades de Aracaju e São Cristóvão. As visitas ocorreram no período de abril a maio de 2018.

A pesquisa foi de natureza qualitativa, quantitativa e exploratória com a finalidade de verificar se as empresas em questão adotam alguma ferramenta de gestão de risco, além de identificar práticas e condições de insegurança visando analisar qual a ferramenta que melhor se adequaria para análise de riscos nos cenários analisados, buscando identificar a técnica de maior eficácia para propor a sua utilização.

Foram realizadas pesquisas ao site da previdência social onde, por meio do anuário estatístico (2015), foram coletados dados referentes a acidentes de trabalho no estado de Sergipe, nas cidades de Aracaju e São Cristóvão relativos aos anos de 2014/2015, tendo em vista que foram os dados mais recentes contemplando a cidade de São Cristóvão, objetivando demonstrar a realidade atual das ocorrências de acidentes de trabalho, comparando assim, com os dados das ocorrências obtidos nas obras.

As visitas feitas a SRH e a SRTE ocorreram no dia 03/05/2018 onde foram coletadas respectivamente as informações necessárias sobre os mapas contendo a área de estudo e sobre as estatísticas de acidentes na construção civil nas cidades de Aracaju/SE e São Cristóvão/SE.

Através do Atlas Digital de Recursos Hídricos e do Software Google Heart Pro, foram coletadas as imagens das cidades de Aracaju e São Cristóvão, ambas, localizadas em pontos do mapa do estado de Sergipe, além das posições das obras visitadas por meio de coordenadas em decimal, projeção UTM, Datum SAD 69, que foram demarcadas nos respectivos mapas com o intuito de detalhar minuciosamente as localizações das obras.

As visitas ao campo foram autorizadas em decorrência do contato entre o elaborador dessa pesquisa e os Engenheiros Civis e/ou de Segurança responsáveis pelas construções. A marcação do dia, data e horário de realização do estudo de campo ocorreu via contato telefônico onde foi liberada a entrada nas obras em questão para exploração dos dados que comporão esse material.

Na visitação aos canteiros foram disponibilizados os programas e documentação de segurança do trabalho, os procedimentos internos de execução de serviços e os projetos das edificações, onde, dados simples foram expostos para melhor composição de informações de cada empreendimento. No decorrer das visitas, vários cenários de risco foram identificados e a partir dessas ocorrências, perguntas eram levantadas sobre o processo construtivo, além de questionamentos direcionados a práticas de gestão de riscos, ambas, registradas para posteriormente serem transcritas e comparadas com itens das normas regulamentadoras no decorrer deste trabalho.

Na obra "A", a visitação ocorreu no dia vinte e seis de abril de dois mil e dezoito das $15 \mathrm{~h}$ ás $17 \mathrm{~h}$, o acompanhamento da visita foi feito com a presença de um técnico de segurança, um Engenheiro civil e um Engenheiro de segurança (orientador deste estudo), todos os profissionais da empresa responsável pela construção do empreendimento forneceram as informações necessárias para enriquecer os dados do trabalho em questão.

Na obra "B", a visita foi realizada no dia três de maio de dois mil e dezoito das $14 \mathrm{~h}$ ás $17 \mathrm{~h}$ e o acompanhamento foi feito pelos Engenheiros civis que também são da área de segurança do trabalho, além da presença do técnico de segurança, este último citado, fez todo o roteiro da visita, mostrando os locais de trabalho e as atividades que estavam sendo executadas, além de apontar os agentes de riscos que estavam presentes em cada atividade.

Nas obras "C, D e E" as visitas foram realizadas no dia quinze de maio de dois mil e dezoito em horários alternados, onde foram disponibilizados os técnicos de segurança de cada obra para acompanhamento. Nas obras " $\mathrm{F}$ e G", as visitas ocorreram no dia dezesseis de maio de dois mil e dezoito também em companhia de um técnico de segurança no período da manhã e em horários distintos.

Além da análise qualitativa por meio das observações "in loco" e baseado na literatura atual de saúde e segurança do trabalho. Utilizou-se processador de texto Microsoft Office (Word-2007) para elaboração de um questionário semiestruturado (APÊNDICE A) para ser preenchido de forma espontânea pelos membros responsáveis pelas ações de segurança das obras, onde, na ocasião, treze perguntas estratégicas 
voltadas à análise de riscos e gestão de segurança dos canteiros visitados foram respondidas pelos mesmos de forma sigilosa, buscando assim, dar maior enriquecimento à pesquisa e por meio das respostas.

As entrevistas foram realizadas com 15 profissionais da área de segurança do trabalho entre técnicos e Engenheiros de Segurança de sete empreendimentos de construtoras diferentes.

Na obra "A", disponibilizaram-se a preencher o questionário dois trabalhadores, sendo 01 (um) Engenheiro de Segurança do Trabalho e 01 (um) Técnico de Segurança.

Na obra "B", a disponibilidade foi um pouco maior devido à quantidade de trabalhadores desse canteiro. Disponibilizaram-se ao preenchimento do questionário quatro trabalhadores sendo 01 (um) Engenheiro de segurança do trabalho, 01 (um) Técnico de Segurança do trabalho e os 02 (dois) Engenheiros Civis que também são Engenheiros de Segurança do Trabalho.

Nas obras "C, D e F", disponibilizaram-se a preencher o questionário dois trabalhadores de cada canteiro, sendo 01 (um) Engenheiro de Segurança do Trabalho e 01 (um) Técnico de Segurança.

Na obra "E" o questionário foi respondido por 01 (um) profissional da área de segurança, o técnico da obra.

Na obra "G", o questionário foi respondido por 01 técnica de segurança do trabalho e por 01 Engenheiro civil que também é Engenheiro de Segurança do trabalho e Perito na área trabalhista.

Para melhor assimilação do conteúdo deste estudo e das ações que foram analisadas e desenvolvidas nas obras, foi solicitado aos responsáveis o registro das visitas por meio de fotografias, no qual foi concedida autorização nas obras “A, B, C, E, F e G", já na obra "D” não foi autorizado o registro de imagens.

Todos os registros fotográficos foram coletados por meio de aparelho celular, onde, serão disponibilizadas as imagens nos resultados dessa pesquisa.

Na pesquisa foram utilizados os seguintes materiais/equipamentos:

- Veículo particular para deslocamento até as áreas de estudo e órgãos oficiais;

- Celular para registro das imagens;

- Prancheta, Caneta e papel para anotação dos dados;

- Computador para armazenamento das informações;

- EPI's (Capacete e botas de couro) para entrada nas obras.

\subsection{ANÁLISE DE DADOS}

Dados voltados às estatísticas de acidentes no Estado de Sergipe e nas cidades de Aracaju e São Cristóvão foram levantados e comparados com os ocorridos nas obras visitadas, assim podendo-se evidenciar que os acidentes típicos ocorrem na maioria das vezes em sua maior totalidade em comparação com os de trajeto e com as doenças do trabalho ou ocupacionais.

As situações de riscos das atividades observadas foram discutidas com os responsáveis pelas obras e serão disponibilizadas no item 4.2 deste trabalho por meio de imagens registradas "in loco" para melhor entendimento da exposição dos operários aos agentes de risco.

Em continuidade ao levantamento dos dados qualitativos e quantitativos aplicou-se questionário semiestruturado (APÊNDICE A), onde na ocasião, questões relacionadas à prática de gestão e sobre o uso de técnicas de gestão de risco foram respondidas pelos entrevistados. Os resultados dos dados colhidos foram consequentemente organizados em tabelas elaboradas, utilizando o editor de planilhas Microsoft Office (Excel - 2007) e ilustrados para melhor entendimento através de gráficos. 


\section{RESULTADOS E DISCUSSÃO}

Os resultados obtidos serão apresentados subdividindo as metodologias aplicadas em: Resultados de pesquisas a órgãos oficiais, Resultados das visitas "in loco" sobre os agentes ambientais de risco identificados nas obras, Resultados do questionário aplicado com os representantes de cada empreendimento e Ferramenta proposta para aplicação nas obras analisadas.

\subsection{RESULTADOS DE PESQUISAS A ÓRGÃOS OFICIAIS}

Por intermédio dos resultados dos questionários realizados com as obras visitadas, podemos verificar no item 3.3 dessa pesquisa um número pequeno nos registros de acidentes de trabalho com CAT, porém, um dado que se mostra evidente e verídico quando comparado com os dados estatísticos da previdência social é a ocorrência em maior proporção dos acidentes do tipo típicos em relação aos acidentes de trajeto e as doenças do trabalho ou ocupacionais.

No ano de 2014, o Estado de Sergipe registrou um total de 3223 acidentes de trabalho, sendo 2511 com CAT registrada e 712 sem CAT registrada. Dos acidentes registrados, foram contabilizados 1855 acidentes típicos - 73,87\% do total das ocorrências, 581 de trajeto - Equivalente a 23,14\% e 75 doenças do trabalho ou ocupacionais $-2,99 \%$ das ocorrências com registro. (AEPS, 2015).

Já no ano de 2015, Sergipe registra um total de 2680 acidentes de trabalho sendo 2166 acidentes com CAT registrada e 514 sem registro. Dos registrados, foram contabilizados 1649 típicos - 76,13\% do total de ocorrências, 488 de trajeto - Equivalente a 22,53\% e apenas 29 doenças do trabalho ou ocupacionais 1,34\% das ocorrências registradas. (AEPS, 2015). Registros expostos na Tabela 1 abaixo:

Tabela 1: Indicadores de acidentes de trabalho ocorridos no Estado de Sergipe (Anos 2014 e 2015).

\begin{tabular}{|c|c|c|c|c|c|c|c|c|c|c|c|c|c|c|}
\hline \multirow{5}{*}{ Local } & \multicolumn{14}{|c|}{ ESTATÍSTICAS DE ACIDENTES DO TRABALHO } \\
\hline & \multicolumn{10}{|c|}{ Com CAT registrada } & \multirow{3}{*}{\multicolumn{2}{|c|}{$\begin{array}{l}\text { Total (com e } \\
\text { sem CAT } \\
\text { registrada) }\end{array}$}} & \multirow{3}{*}{\multicolumn{2}{|c|}{ Óbito }} \\
\hline & \multirow{2}{*}{\multicolumn{2}{|c|}{ Típico }} & \multicolumn{2}{|c|}{ Motivo } & \multirow{2}{*}{\multicolumn{2}{|c|}{$\begin{array}{l}\text { Doença do } \\
\text { trabalho ou } \\
\text { ocupacional }\end{array}$}} & \multirow{2}{*}{\multicolumn{2}{|c|}{ Total }} & \multirow{2}{*}{\multicolumn{2}{|c|}{$\begin{array}{l}\text { Sem CAT } \\
\text { registrada }\end{array}$}} & & & & \\
\hline & & & Tra & jeto & & & & & & & & & & \\
\hline & 2014 & 2015 & 2014 & 2015 & 2014 & 2015 & 2014 & 2015 & 2014 & 2015 & 2014 & 2015 & 2014 & 2015 \\
\hline Sergipe & 1.855 & 1.649 & 581 & 488 & 75 & 29 & 2.511 & 2.166 & 712 & 514 & 3.223 & 2.680 & 19 & 14 \\
\hline
\end{tabular}

No ano de 2014, o Estado de Sergipe com 2511 acidentes registrados tem na cidade de Aracaju um maior número dessas ocorrências 1.547 acidentes, correspondendo a $61,61 \%$ do total das ocorrências de Sergipe. Desses, 1154 são acidentes típicos, 337 são acidentes de trajeto e 56 correspondem à doença do trabalho ou ocupacionais. (AEPS, 2015).

Já na cidade de São Cristóvão os números demonstrados foram de 49 acidentes - 1,95\% dos acidentes ocorridos em Sergipe, com 23 do tipo típico, 24 de trajeto e 2 doenças do trabalho ou ocupacionais. (AEPS, 2015)

Já em 2015, Sergipe apresenta 2166 acidentes de trabalho, Aracaju, mesmo com uma pequena redução em relação ao ano anterior, apresenta ainda 1.306 ocorrências registradas, totalizando 60,30\% dos registros de acidentes de Sergipe. Desses, 1001 são acidentes típicos, 288 são acidentes de trajeto e 17 são referentes a doenças do trabalho ou ocupacionais. (AEPS, 2015).

Em seguida, São Cristóvão demonstra também um numerário menor que o ano anterior totalizando 42 acidentes, 1,94\% dos acidentes registrados em Sergipe. Dessas ocorrências, 24 são acidentes típicos, 16 são de trajeto e 02 são referentes a doenças do trabalho ou ocupacionais. (AEPS, 2015).

A Tabela 2 a seguir traz os números referentes aos anos citados nas cidades de Aracaju e São Cristóvão

Os dados apresentados são apenas com CAT registrada, esses números com certeza são bem maiores conforme a Tabela 2, pois leva em consideração também a quantidade total de acidentes sem registros. Em Aracaju, no ano de 2014 ocorreram 459 acidentes que não foram registrados por meio da CAT e em 2015 o numerário foi de 368 acidentes que deveriam ter sido registrados. Em São Cristóvão, no ano de 2014 
também houve ocorrências que não foram registradas por meio da CAT, totalizando 08 acidentes e no ano de 2015 os números das ocorrências sem registro foram um pouco maiores, 12 acidentes.

Tabela 2: Indicadores de acidentes de trabalho ocorridos nas Cidades de Aracaju e São Cristóvão (Anos 2014 e 2015).

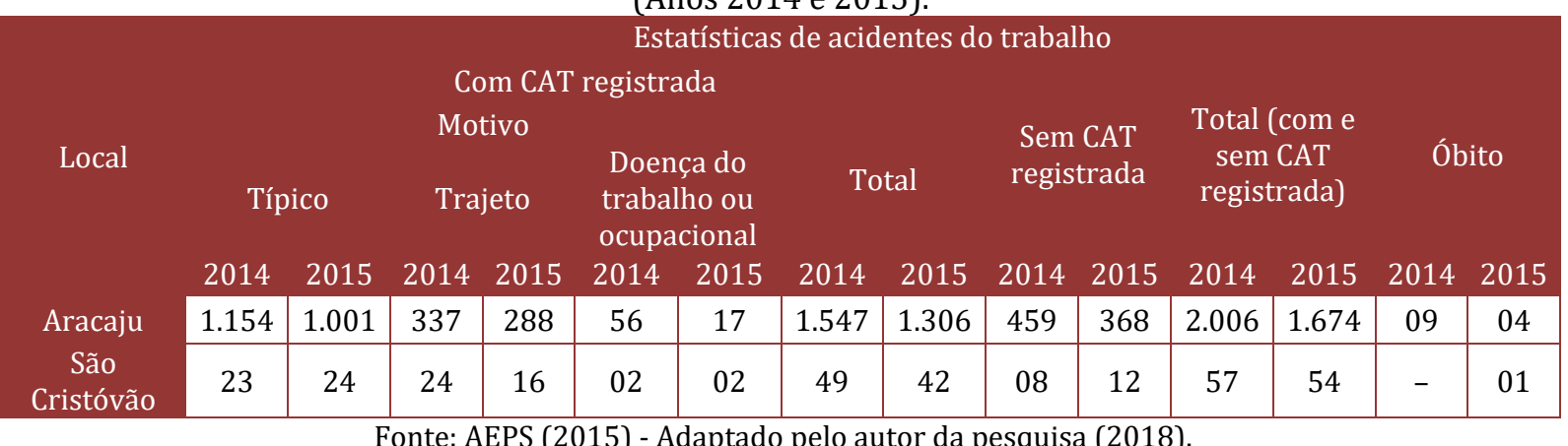

\subsection{RESULTADOS DAS VISITAS "IN LOCO" SOBRE OS AGENTES AMBIENTAIS DE RISCO IDENTIFICADOS NAS OBRAS}

Durante as visitas para coleta de dados nas obras A, B, C, D, E, F e G foi possível identificar por meio da aplicação de questionários e dos registros fotográficos com exceção da obra " $\mathrm{D}$ " devido não ter sido concedido autorização pela empresa visitada. Alguns riscos iminentes foram observados e catalogados a saber: os físicos, químicos, biológicos, ergonômicos e aqueles que podem demandar acidentes.

\section{A - OBRA "A"}

Um fator de suma importância em uma obra é a questão do transporte e movimentação de forma garantida e segura dos materiais a serem utilizados e da mão de obra humana. Medidas preventivas para a circulação de trabalhadores na área, onde estão sendo descarregados materiais são imprescindíveis, uma vez que cada equipamento requer cuidados específicos.

Se faz mister destacar a observação do equipamento verificando se de fato ele atende, às necessidades da obra, bem como aos requisitos de segurança determinados pelas normas técnicas vigentes, sobretudo a NR-18 (2015) que trata especificamente de garantir a saúde e a integridade dos trabalhadores; definir atribuições e responsabilidades às pessoas que administram a obra; fazer previsão dos riscos que derivam do processo de execução de obras; determinar medidas de proteção e prevenção que evitem ações e situações de risco; aplicar técnicas de execução que reduzem ao máximo os riscos de doenças e acidentes.

As imagens abaixo mostram trabalhadores expostos ao içamento de perfil metálico, o que caracteriza o risco de queda como predominante nessa atividade. Pode-se verificar a falta de conhecimento dos trabalhadores o que nos leva acreditar que as medidas administrativas falharam e não houve treinamento adequado, suficiente ou até mesmo eficaz para a situação em questão. Perguntado sobre a aplicação dos treinamentos, o técnico de segurança afirmou que pelo menos duas vezes na semana ministra os DDS, mas que diariamente, percorre o canteiro orientando os operários sobre os riscos. Complementa ainda que essas ocorrências vêm da falta de percepção de risco por parte dos operários e da preocupação direta com a produtividade que muitas vezes acabam deixando a segurança de lado. 
A Figura 2 apresenta trabalhador exposto ao içamento de carga no canteiro da obra "A".

Figura 2: Mostra exposição de trabalhador ao risco de queda de material.

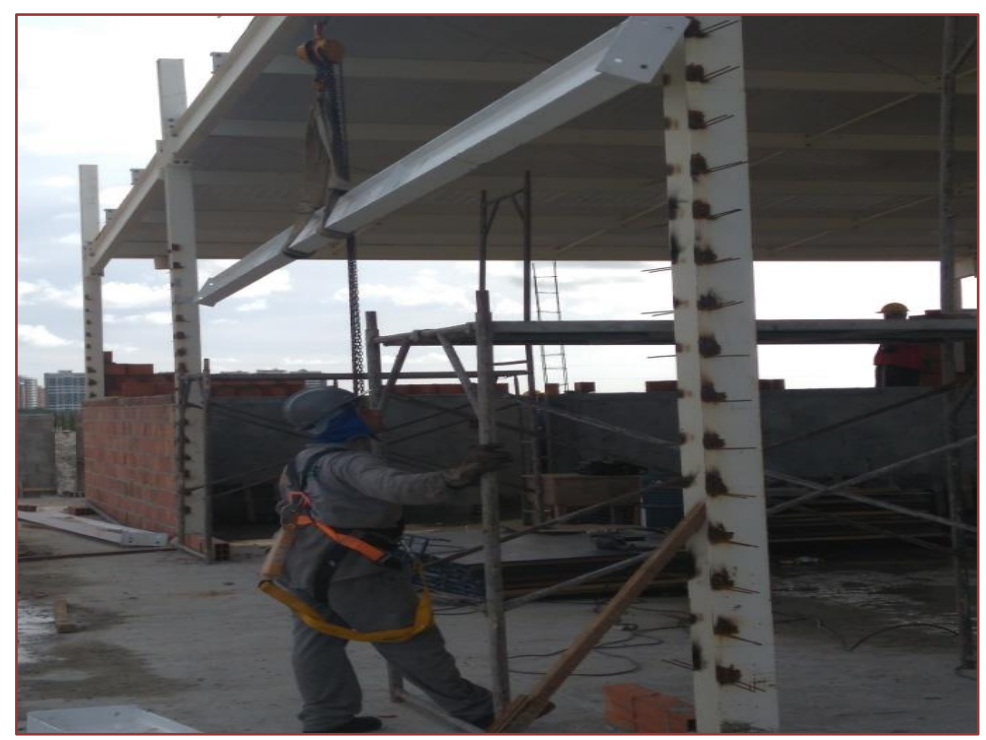

Fonte: Trabalho de campo, 2018

Foi possível identificar ainda na obra "A", o transporte irregular vertical de materiais e equipamentos, o que de acordo com a NR18 (2015), precisa ter um local bastante adequado para tal movimentação, para que garanta todos os meios de proteção necessários ao trabalhador.

De acordo com Vieira (2006) é uma obrigação das empresas cumprir as normas vigentes, sobretudo no tocante a proteção dos trabalhadores em obras que se expõem a riscos constantes, é imprescindível cumprir a legislação, quando se trata de forma correta o trabalhador, a empresa também ganha em qualidade.

Outra situação que ficou perceptível na obra "A" são os riscos elevados de acidentes na utilização incorreta dos andaimes. Estes são estruturas utilizadas na sustentação dos trabalhadores que executam trabalhos em locais de difícil acesso, relacionados à altura. A NR 18 (2015) em seu subitem 18.15 .6 discorre que todo andaime deve atender aos requisitos básicos de segurança dispondo do sistema guarda-corpo e rodapé, sobretudo nas cabeceiras e em toda a extensão onde eles estejam fixados.

A Figura 3 apresenta com bastante ênfase a falta de tais proteções, o que de súbito já se pode perceber o risco de acidente. Andaime sem guarda-corpo e rodapé.

Figura3: Andaime sem guarda-corpo e rodapé.

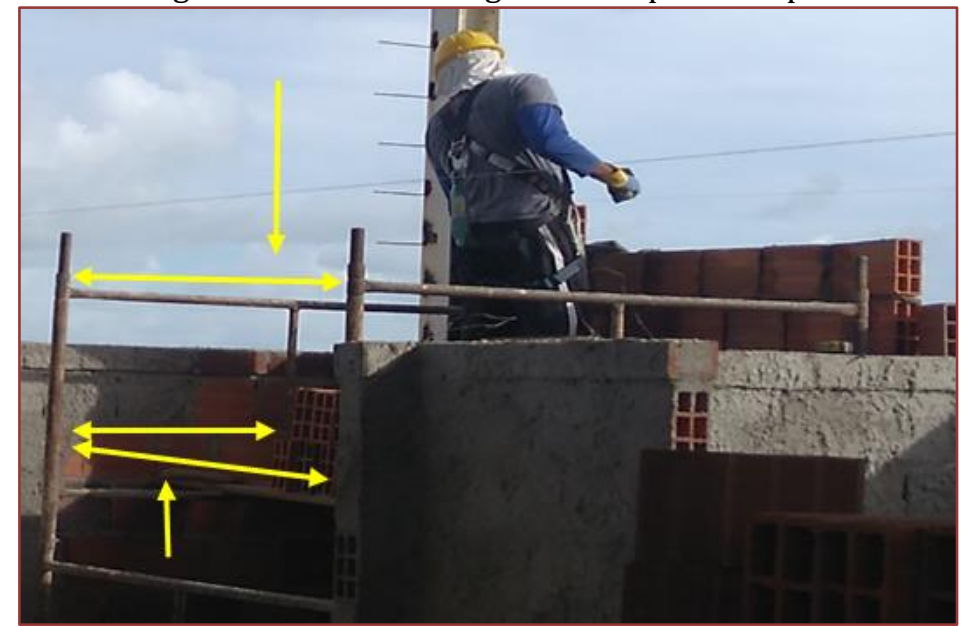

Fonte: Trabalho de campo, 2018. 
Os equipamentos de proteção individual (EPI) são indispensáveis em qualquer trabalho, sobretudo na construção civil, uma vez que os riscos de acidentes são mais propensos em se tratando de uma obra. Deixar de utilizar o EPI pode inclusive levar a acidentes mais sérios ao trabalhador.

Segundo a NR-6 (2017) um dos EPI's que trazem segurança contra os riscos de queda na obra, diz respeito ao cinturão, este deve ser usado corretamente para proteger contra as quedas em trabalho de altura.

Sobre esse EPI a NR 18 (2015, pg. 42) destaca:

18.23.3.1 0 cinto de segurança deve ser dotado de dispositivo trava-quedas e estar ligado a cabo de segurança independente da estrutura do andaime. (Incluído pela Portaria SSST n.․ 63, de 28 de dezembro de 1998).

Durante a observação da obra A, ainda foi possível encontrar trabalhadores sem o uso adequado dos EPI's. Sobre a proteção dos membros superiores a NR-6 (2017) aponta que se faz necessário o uso das luvas, de protetor solar, camisa com mangas, braçadeiras e dedeiras.

Alguns colaboradores estavam a desenvolver o seu trabalho sem o uso de luvas. Estas são extremamente necessárias para a proteção contra agentes que corroem ou cortam, também protegem as mãos contra choques elétricos, e abrasivos.

As luvas são indispensáveis em diversas atividades diárias, devendo o trabalhador ser treinado quanto ao uso, guarda e manutenção. Em caso de desgaste deverá solicitar e empresa substituição imediata. Além da proteção as luvas fornecem conforto aos trabalhadores durante o expediente diário, evitando assim acidentes e possíveis gastos médicos.

Foi encontrada também na obra "A" a postura inadequada dos trabalhadores onde fica claro que a ergonomia não é discutida com os mesmos. A Ergonomia para Iida (2014) é a ciência que estuda como o homem se adapta ao seu trabalho e para tanto ele deve sentir-se confortável e seguro para desenvolver bem suas atividades.

A NR-17 (2007) aborda no tocante a ergonomia que se faz necessário que sejam adequados às características psicofisiológicas dos trabalhadores, a todos os equipamentos que forem utilizados em seus postos de trabalho, e a norma ainda destaca que é importante observar as condições do ambiente de trabalho, corroborando para o bem-estar físico, psicológico e social.

O próximo cenário mostra trabalhador tendo que se agachar para ter acesso ao caixote que contém a massa de cimento. No que tange a norma NR-17 sobre o mobiliário e suas dimensões, incluindo distâncias e altura, determina que no local da atividade devam ser respeitados os alcances dos membros de acordo com as características antropométricas dos trabalhadores. Devendo ter a área de manipulação compatibilizada com a área de visão do trabalhador. (NR-17, 2007).

A Figura 4 mostra a postura inadequada podendo ocorrer lesão na coluna, devido o operário ter que se agachar para pegar o cimento.

Figura 4: Mostra a postura inadequada do trabalhador.

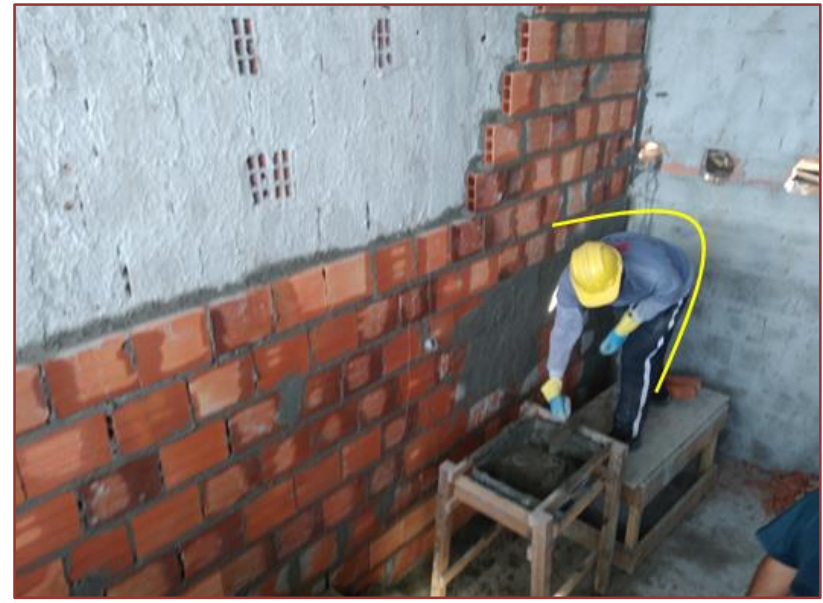

Fonte: Trabalho de campo, 2018. 
A manipulação de substâncias químicas de forma incorreta na obra traz sérios danos à saúde do operário, é importante que ele seja consciente do uso dos equipamentos necessários. Na obra A encontramos a manipulação de duas matérias-primas muito utilizadas na construção civil: o gesso e o cimento. Estes se constituem em grande forma de contaminação ao operário durante sua manipulação.

A NR-9 (2017, pg. 1) apresenta no subitem 9.1.5.2 o que considera agente químico, a saber:

Consideram-se agentes químicos as substâncias, compostos ou produtos que possam penetrar no organismo pela via respiratória, nas formas de poeiras, fumos, névoas, neblinas, gases ou vapores, ou que, pela natureza da atividade de exposição, possam ter contato ou ser absorvidos pelo organismo através da pele ou por ingestão.

Agentes desse tipo segundo Costa (2014), são capazes de gerar fenômenos mutagênicos, carcinogênicos, teratogênicos, organotóxicos e imunotóxico, causando sérios danos à saúde dos profissionais que os manuseiam. A Figura 5 apresenta trabalhador utilizando o cimento sem luvas, passíveis desse modo de contaminação.

Figura 5: Trabalhador manipulando cimento sem uso de luvas.

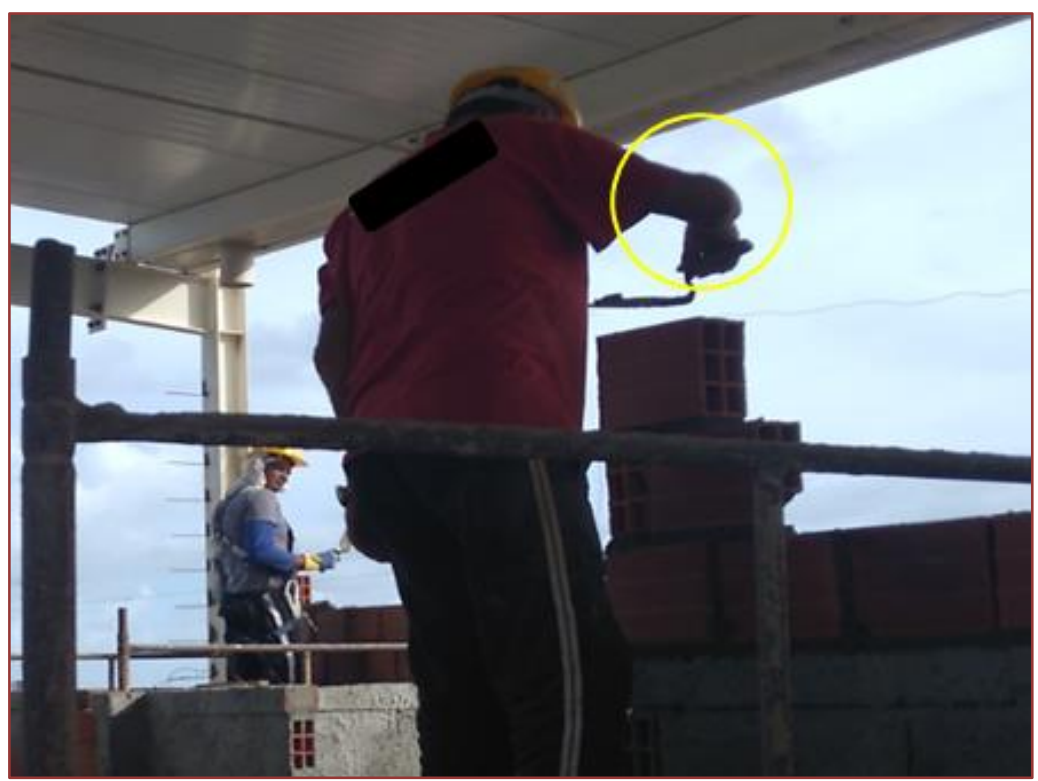

Fonte: Trabalho de campo, 2018.

\section{B - OBRA “B”}

Durante a visita na obra "B", foi possível perceber algumas atividades que expõem os operários a riscos de acidentes. Um deles se refere ao risco físico, este de acordo com a NR-9 (2017) apresenta os agentes físicos como tudo aquilo a que o trabalhador está exposto na obra, ou seja, o barulho (ruídos), vibrações, temperaturas, radiações. Observando os trabalhadores, encontramos alguns trabalhando expostos ao risco físico ruído.

No caso de exposição ao ruído, a NR-15 (2014) destaca no seu anexo n. 1 (limites de tolerância para ruído contínuo ou intermitente), que para atividades com duração até 8hs diária, os níveis de ruído não deverão ultrapassar o limite de 85 Decibéis, lembrando-se da importância do uso obrigatório do EPI.

Em consonância com o que descreve os tipos de riscos ambientais, pode-se destacar a iluminação como um risco ergonômico. A NR-17 (2007) trata especificamente dos riscos ambientais no trabalho e em seu texto descreve com clareza que é obrigatório a uniformidade, com ausência, sobretudo de efeitos não desejáveis como ofuscamento e/ou contraste, e estar em conformidade com a iluminância nos planos de trabalho normatizados pela NBR 5413.

Para a NBR 5413 (1992), por iluminância compreende-se a quantidade de luz que reflete num determinado espaço. Na obra $\mathrm{B}$, à iluminação interna estava de forma precária o que pode ocasionar sérios 
riscos à saúde do trabalhador, sejam esses riscos físicos ou psicológicos, afetando o seu desempenho podendo causar também acidentes de trabalho.

O subitem 2.1 da NBR 6494 apresenta andaimes como superfícies elevadas de suma importância para o trabalho em alturas. Geralmente são muito utilizados na construção civil em serviços que requeiram reforma, pintura, limpeza e manutenção.

Segundo a NR-35 (2016), um ponto importante a ser lembrado aponta para o fato que deve ser considerado trabalho em altura, todo aquele que é praticado acima de dois metros do nível inferior, em local onde exista risco de queda.

A NR-35 (2016) apresenta os mínimos requisitos necessários para o trabalho em altura. Segundo a norma, para essas atividades deve-se levar em consideração todo o planejamento, a questão da organização e a execução, de modo que garanta a saúde de todos os envolvidos no processo.

Para atividades incluídas nesse contexto, o empregador deverá promover a capacitação dos trabalhadores por meio de treinamentos específicos, teórico e prático em NR-35 (Trabalho em altura). Deverá fornecer os epi's obrigatórios para a atividade, como: cinto de segurança tipo paraquedista ligado ao dispositivo trava quedas, este acoplado em linha de vida presa a elemento estrutural resistente. A Figura 6 apresenta na obra "B" trabalho com andaimes suspensos com risco de acidentes por queda em altura e por queda de materiais:

Figura 6: Atividade em andaime suspenso.

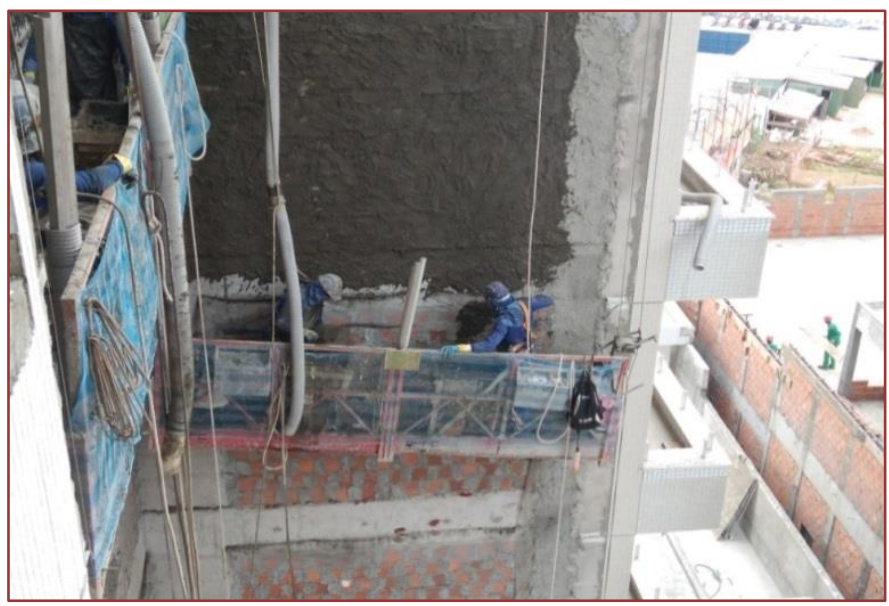

Fonte: Trabalho de campo, 2018.

\section{C - OBRA “C”}

A obra em questão está iniciando suas atividades e encontra-se no processo de fundações. No canteiro, um equipamento chamado hélice contínua está perfurando o solo com um trado helicoidal e injetando o concreto por meio de uma haste central, no qual, procedimentos de segurança também deverão ser adotados para a segurança dos trabalhadores presentes independente do estágio inicial da obra.

Devido ao tamanho do equipamento mostrado na Figura 7 e da movimentação deste no canteiro de obra, o terreno deverá possuir um espaço amplo e ser levemente nivelado para que a máquina perfuratriz se movimente sem trazer risco aos trabalhadores. As áreas por onde há circulação de pessoas deverão estar sinalizadas e protegidas do contato de máquinas com os operários. Fato contrário foi verificado no momento da visita devido a falta da sinalização/isolamento interno, facilitando assim o risco de acidente devido aproximação dos trabalhadores com a máquina. De acordo com a norma "Fica proibido o acesso de pessoas não autorizadas nas áreas de escavação e cravação de estacas” (NR-18, 2015, pg. 9). 
Figura 7: Mostra circulação de trabalhador próximo as máquinas.

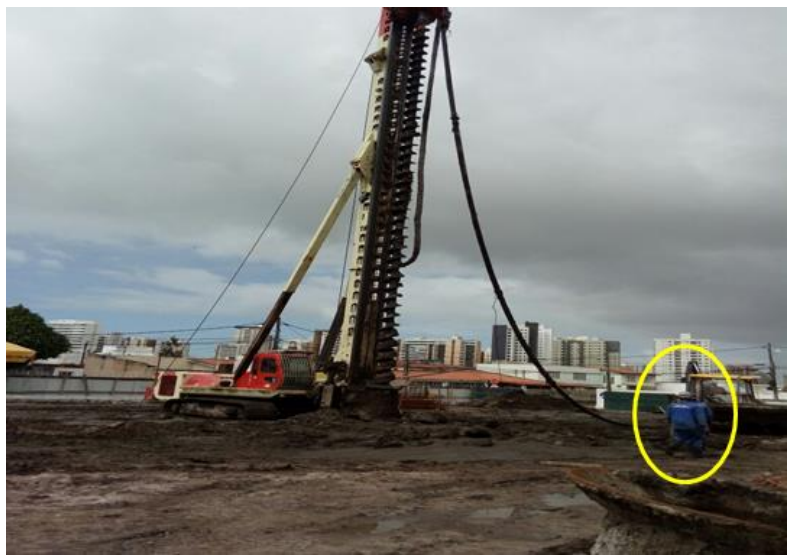

Fonte: Trabalho de campo, 2018.

\section{D - OBRA “E”}

Pode-se observar na Figura 8 que no momento da visita os trabalhadores faziam uso dos Epi's nos serviços de pavimentação na área das garagens do empreendimento. Para execução dessa atividade estava sendo utilizado capacete, bota de couro, máscaras, luvas, protetor auricular e óculos. Os riscos predominantes são o químico, ergonômico e de acidentes. 0 químico, devido ao contato com substâncias químicas inerentes do material trabalhado, ergonômico em decorrência da postura inadequada e de acidentes devido ao trabalho com ferramentas e máquinas.

A NR-6 (2017) menciona no seu texto sobre a obrigatoriedade do fornecimento e fiscalização quanto ao uso dos epi's por parte dos empregadores, além da obrigatoriedade no uso por parte dos empregados.

Foi perguntado ao técnico de segurança da obra se a empresa fornece frequentemente os Epi's adequados ao risco de cada atividade e o profissional do SESMT respondeu que fornece frequentemente, entretanto muitos operários ainda resistem em utilizar.

Figura 8: Uso dos Epi’s em atividade de pavimentação.

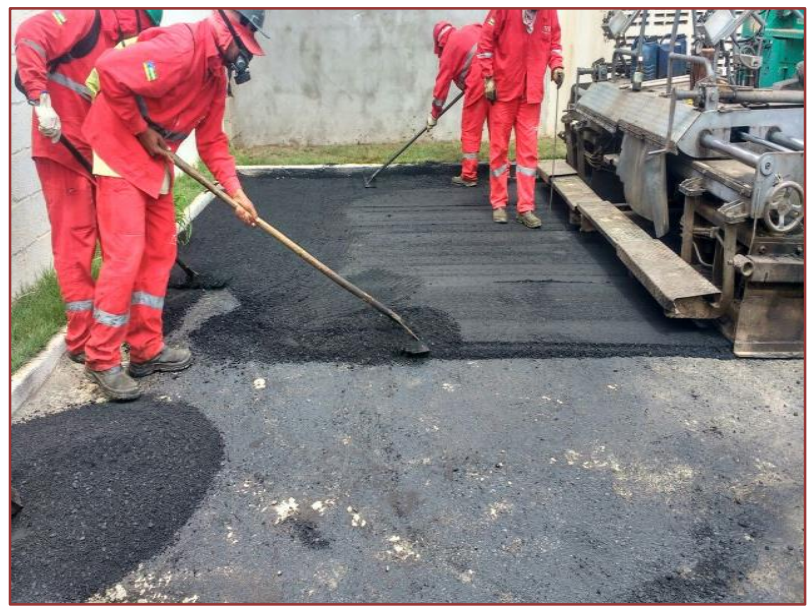

Fonte: Trabalho de campo, 2018. 
Outro setor que foi visitado foi o setor de armação, local onde é executado o corte e a dobra do aço. Para essa atividade de corte, o trabalhador estava colocando seus epi's, que de acordo com ele são: Capacete, bota de couro, luvas de raspa, avental de raspa, máscara total facial e protetor auricular tipo concha. Os riscos predominantes dessa atividade são:

Os físicos: Ruído e vibrações decorrentes da máquina policorte; E o de Acidentes: Decorrente da projeção de material no corpo e visão, cortes em membros devido a armazenamento impróprio e manipulação de ferragens de forma inadequada, além do risco de contato acidental com o disco de corte no movimento de rotação gerado pelo equipamento.

0 ambiente de trabalho se apresentava organizado e devidamente restrito ao acesso de terceiros, além de possuir sinalização adequada quanto aos riscos.

Segundo Silva (2017), os locais para corte e manuseio de aço deverão ser restritos e sinalizados e o local de armazenamento do aço deverá ter sinalização e isolamento adequados. Além disso, deverá ser realizado check-list de inspeção das condições do equipamento e realizar manutenções preventivas, visando assim correção de possíveis falhas.

A principal legislação que rege o uso de máquinas e equipamentos determina que toda empresa adote medidas de proteção nas máquinas e equipamentos visando garantir o bem-estar dos operários. (NR-12, 2018).

Outra atividade observada foram os serviços de pintura na fachada da edificação, serviço bastante perigoso devido ao trabalho em altura como se pode verificar na Figura 9. 0 trabalhador que estava realizando a atividade utilizava um equipamento chamado de cadeira suspensa, mais conhecida por "Cadeirinha". Este serviço requer cuidados, pois o risco predominante é o de queda de altura. Para esta atividade, além de ter que saber manipular este equipamento, o trabalhador deverá ter a saúde avaliada pela empresa para assim ser considerado apto para executar a tarefa, devendo ainda receber os treinamentos necessários e por final, ter a permissão formal da empresa.

De acordo com a NR-35 (2016), as empresas deverão promover a capacitação dos trabalhadores quando da realização de atividades em locais elevados.

Quando perguntado ao técnico de segurança da área se o trabalhador tinha os requisitos necessários para a atividade (treinamentos, avaliação da saúde, autorização da empresa, dentre outros) o mesmo informou que sim, e, que antes de iniciar as atividades é realizado um check-list das condições do local de trabalho, das ancoragens, assim como da cadeira suspensa e de seus componentes. Após toda a checagem só inicia as atividades após a emissão de documento chamado de PT (Permissão de Trabalho), onde todos assinam, atestando as boas condições de trabalho.

Figura 9: Atividade em cadeira suspensa

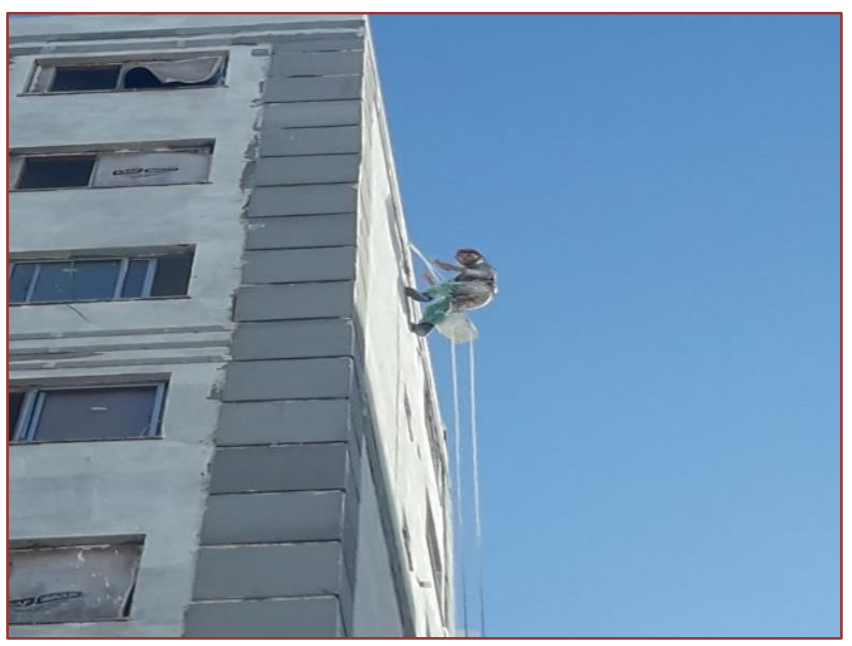

Fonte: Trabalho de campo, 2018. 


\section{E - OBRA "F"}

No empreendimento em destaque vislumbramos atividade realizada sobre andaimes do tipo fachadeiro, onde trabalhadores realizavam reboco na fachada da edificação. Os riscos mais presentes nessa atividade são os químicos - manipulação de cimento e seus agregados e os riscos de acidentes - queda de materiais sobre pessoas e queda com diferença de nível devido ao trabalho em andaime. Todos os operários faziam uso dos epi's necessários tais como: cinto de segurança, dispositivo trava quedas, luvas, capacetes, botas e outros.

Segundo Cruz (2018) os trabalhos em andaimes podem trazer consigo riscos elétricos devido à instalação dos andaimes próximos as redes elétricas e o risco de quedas de altura proveniente de desequilíbrio do trabalhador, desgaste da plataforma de trabalho causando sua ruptura, queda de ferramentas ou material de trabalho, dentre outros.

Outra atividade apreciada nesse canteiro de obras foi o abastecimento das torres por meio de movimentação e transporte de materiais do tipo massa de cimento, blocos e esquadrias. Esses materiais estavam sendo içado por equipamento de guindar, mais conhecido como "guindaste". Nessa atividade, o risco que predomina é a queda de materiais sobre as pessoas podendo ocasionar acidentes graves e até fatal. A área onde estava sendo executada a atividade encontrava-se sinalizada/isolada, evitando assim o acesso e a permanência de pessoas no local.

No transporte vertical de argamassas ou outros materiais, a circulação ou permanência de pessoas deve ser impedida com isolamento ou sinalização. (SILVA, 2017).

0 técnico de segurança da obra informou que essa atividade requer muita atenção tanto do operador, quanto dos trabalhadores que o auxiliam na atividade de subida de material. Informa ainda que a comunicação deve ser constante e que para isso, a obra fornece rádios comunicadores para que todos estejam sempre conectados, evitando assim, erros no processo de abastecimento.

\section{F - OBRA "G"}

Nesta obra também foi evidenciada atividades externas envolvendo içamento de material. A principal norma regulamentadora que trata sobre esse tema é a NR-11 (Transporte, Movimentação, Armazenagem e Manuseio de Materiais), nela está contida procedimentos que deverão ser seguidos para evitar acidentes, destacando itens do tipo qualidade, resistência e conservação dos equipamentos.

Demais itens merecem destaque no contexto dessa norma como: Qualificação dos operadores e inspeção dos equipamentos (sinalização sonora, cabos, cintas e correntes em boas condições, disposição da capacidade de carga máxima permitida em toda e sua estrutura do equipamento, dentre outras).

Quando perguntado sobre check-list e manutenções preventivas nas máquinas e equipamentos, a técnica de segurança do canteiro respondeu que periodicamente, de acordo com os manuais dos equipamentos, a empresa tem uma equipe de manutenção que é solicitada para manter os equipamentos com a preventiva sempre em dia.

De acordo com a NR-11 (2016) deverá ser dada atenção especial aos cabos de aço, roldanas, ganchos e outras partes dos equipamentos, realizando inspeção permanente e realizando manutenções para troca de peças quando estiverem danificadas.

Os serviços internos também foram mostrados pela técnica de segurança e duas atividades estavam sendo realizadas na edificação: A aplicação de gesso corrido em paredes e teto e o reboco de paredes da varanda. Os riscos predominantes eram queda de altura e manipulação de produtos químicos, ambos, necessitando de atenção em relação a procedimentos normativos (NR-6, NR-18 e NR-35). Quando perguntado a técnica de segurança se os trabalhadores recebem orientações sobre esses agentes ela informou que todos os dias realiza os DDS mostrando a importância da prevenção.

Nesse contexto, Oliveira (1998) manifesta que o processo de capacitação do pessoal com treinamentos sobre prevenção de acidentes é importante para se obter segurança, evitando assim as ocorrências indesejáveis. 


\subsection{RESULTADOS DO QUESTIONÁRIO APLICADO}

Nas entrevistas realizadas com os profissionais da área de segurança do trabalho, verificou-se de uma forma geral que boa parte dos entrevistados (10 pessoas), equivalente a $66,67 \%$ dizem ter conhecimento das normas de gestão de risco e apenas 05 pessoas mencionaram não conhecer as referidas normas, cerca de 33,33\% do público. A Figura 26 demonstra os resultados do conhecimento das normas de gestão de risco por obra. Na Obra "A" $50 \%$ dos entrevistados afirmam ter conhecimento das normas de gestão de risco e 50\% não conhecem; Na obra "B", $75 \%$ dos entrevistados informaram conhecer e somente $25 \%$ não conhecem; Nas obras "C e D" $100 \%$ dos entrevistados afirmaram ter conhecimento destas normas de gestão; Já na obra "E" um percentual de 100\% dos entrevistados dizem não ter conhecimento das normas; Nas obras "F e G" metade dos entrevistados 50\% afirmam conhecer e os outros $50 \%$ não conhecem essas referidas normas de gestão de risco.

Sobre o questionamento referente ao conhecimento das ferramentas/técnicas de gestão, somente 03 (três) dos 15 (quinze) entrevistados relatam não ter conhecimento, equivalente a $20 \%$ do público alcançado, e, $80 \%$ afirmam conhecer algumas das técnicas.

Por meio das descrições abaixo pode-se verificar minunciosamente um panorama do conhecimento das técnicas de gestão de riscos pelos entrevistados.

Na obra "A" o técnico de segurança informa não conhece as NBR's voltadas à gestão de riscos, assim como nenhuma das ferramentas citadas no questionário. Já o Engenheiro de Segurança descreve conhecer as NBR's 31000 e 31010 e algumas das ferramentas de gestão apresentadas, apontando a APP, Árvore de Causas, Árvore de Falhas e Hazop. Declara não fazer uso destas técnicas devido à falta de interesse e apoio da alta gestão.

Na obra "B" a situação foi bem diferente devido à quantidade maior de entrevistados, o técnico de segurança disse conhecer as normas de gestão de risco, porém não tem conhecimento das técnicas utilizadas e que nunca trabalhou com elas. Já os Engenheiros Civis, que também são de Segurança do trabalho dividiram seus relatos, 1 (um) afirma não conhecer as normas, porém na pós-graduação ouviu falar das técnicas TIC, What If, APP, AMFE, Árvore de Causas e de Falhas e Hazop.

O outro Engenheiro civil também com especialização na área mencionou conhecer as normas e a ferramenta Árvore de Falhas. O Engenheiro de Segurança do trabalho do canteiro informa conhecer as NBR's de gestão de riscos, além das ferramentas APP, Árvore de Causas e de Falhas e Hazop, ainda na resposta, afirma já ter trabalhado com a técnica da APP.

Na obra "C" tanto o técnico quanto o Engenheiro de Segurança do trabalho dizem ter conhecimento da existência das normas de gestão de risco, assim como complementam o diálogo afirmando já ter utilizado a APP. O primeiro citado declara conhecer a APP e a Árvore de Causas. Já o Engenheiro de Segurança descreve ter conhecimento da APP, Árvore de Causas e de Falhas e Hazop.

Na obra "D" técnico e Engenheiro de segurança garantem conhecer as normas de gestão de risco. Segundo o técnico de segurança, conhece as Árvores de Falhas e Causas. 0 Engenheiro, por sua vez disse conhecer além das árvores de falhas e causas, a APP e Hazop.

Na obra "E" o técnico de segurança disse não conhecer as normas de gestão de risco, mas afirma ter ouvido falar no curso técnico sobre duas das técnicas: A Árvore de Falhas e de causas. Garante o profissional ter interesse em utilizar uma das duas em uma próxima obra.

Na obra " $F$ " os conhecimentos foram divididos tendo o técnico de segurança como não conhecedor das normas de gestão de riscos, entretanto afirma conhecer a técnica árvore de falhas. 0 Engenheiro de segurança, por sua vez, admite ser conhecedor dessas normas além de algumas das técnicas de gestão: APP, Hazop e árvores de falhas e causas.

Na obra "G" o Engenheiro civil e também de segurança confessa conhecer as normas de gestão de riscos e as técnicas das árvores de falhas e causas. Já a técnica de segurança disse não ter conhecimento das normas nem das ferramentas de gestão.

Podemos verificar que dos 15 (quinze) entrevistados, 11 (onze) afirmam conhecer ou já terem ouvido falar da ferramenta árvore de falhas, número equivalente a 73,33\% do público; A segunda ferramenta mais mencionada foi à árvore de causas, sendo citada por 10 (dez) entrevistados, atingindo 66,67\% de conhecedores; A ferramenta APP foi a terceira mais citada por 07 (sete) pessoas, equivalendo a 46,67\%; As demais citadas foram HAZOP por 06 (seis) entrevistados, $40 \%$ do pessoal, TIC e WHAT IF citadas por 
apenas 01 (uma) pessoa, 6,67\% e a AMFE que não foi citada por nenhum dos entrevistados. As informações relatadas acima poderão ser evidenciadas na Figura10.

Figura10: Gráfico sobre o panorama de conhecimento das técnicas de gestão de riscos (Demonstrativo por percentual).

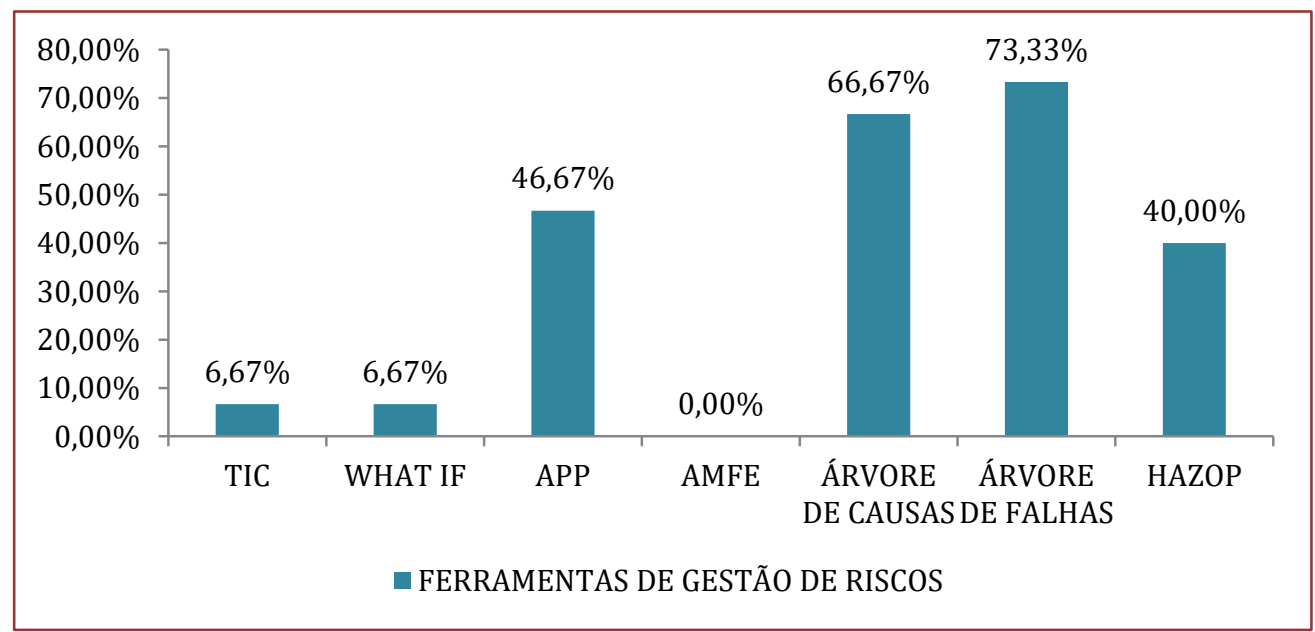

Fonte: Elaborado pelo autor da pesquisa (2018).

Sobre o questionamento de a obra possuir programas/ferramentas de gestão de risco voltados à saúde e segurança do trabalho, verificou-se que todas as 07 (sete) obras relacionadas na pesquisa fazem uso dos programas de saúde e segurança do trabalho (PCMAT, PPRA e PCMSO). De acordo com a legislação vigente em saúde e segurança do trabalho, as empresas deverão seguir as diretrizes contidas nesses programas.

Todos os entrevistados das obras “B, C, D, E e F” foram unânimes em dizer que suas obras seguem o que está sendo estabelecido nos programas. Nas obras "A e G" alguns profissionais responderam que as obras cumprem parcialmente essas diretrizes.

O técnico de segurança da obra "A" informou no questionário que a obra/empresa segue parcialmente essas diretrizes. Segundo ele, especificações básicas de projeto das proteções coletivas constantes no PCMAT não são seguidas à risca, a falta de rodapés em andaimes e em proteções de periferias são exemplos de descumprimento do PCMAT, outro item mencionado foi o PCMSO que não segue as especificações do PPRA em relação a funções e riscos.

Na obra "G" o Engenheiro Civil que também é especialista na área de segurança do trabalho relata que a empresa/obra cumpre parcialmente as diretrizes dos programas, pois, segundo ele, o efetivo para fiscalizar os programas x execução real é insuficiente, deixando assim de executar algumas ações impostas nos programas.

O PCMAT (Programa de Condições e Meio Ambiente de Trabalho na Indústria da Construção) é de acordo com a NR-18 (2015) documento obrigatório nos estabelecimentos que possuírem 20 (vinte) ou mais pessoas e de acordo com os dados constantes nos questionários e já mencionados anteriormente na metodologia desse estudo, todas as obras possuem acima desse numerário.

Já o PPRA, regulamentado pela NR-9, é obrigatório em estabelecimentos que possuam menos ou até 19 (dezenove) trabalhadores e foi observado que nas sete obras do estudo o PPRA não está inserido dentro do PCMAT e sim impresso como documento único, que, de acordo com a NR-18 (2015), isso poderá ser feito desde que o PCMAT contemple as exigências do Programa de Prevenção dos Riscos Ambientais.

O PCMSO, regido pela NR-7 também é obrigatório e foi verificado que as obras visitadas possuem tal documento. De acordo com a NR-7 (2013) os empregadores que admitam trabalhadores como empregados deverão elaborar e implementar o programa visando a promoção e preservação da saúde dos seus trabalhadores.

Sobre o uso de ferramentas/técnicas auxiliares para gestão de riscos, somente a obra "E" informou não utilizar no seu canteiro. Já as demais obras (A, B, C, D, F e G) afirmam utilizar a APP, mas, quando solicitado o documento, os representantes das obras apresentaram formulários bem parecidos que constava 
somente o levantamento dos riscos, as causas, consequências e a proteção adequada, não contendo na documentação as categorias de frequência e severidade, itens indispensáveis para se implantar uma APP no local de trabalho.

Mesmo com 12 (doze) pessoas, ou seja, 80\% do pessoal entrevistado afirmando conhecimento ou já ter ouvido falar nas ferramentas de gestão de riscos, não foi evidenciado em nenhum dos canteiros visitados o uso de nenhuma das técnicas, fato preocupante devido a NR-18 (2015) no seu item 18.37.7.4 determinar que as atividades que envolvam soluções alternativas só poderão ser iniciadas após serem analisadas por meio da Análise Preliminar de Risco - APR, contemplando todas as ações e procedimentos necessários para a execução segura da tarefa.

Ressalta Cruz (2014) que o uso das ferramentas de gestão tem a importante finalidade de evitar o impacto negativo dos riscos sobre pessoas, equipamentos, instalações, meio ambiente, patrimônios ou processos.

Foi levantado um questionamento aos entrevistados sobre o respaldo fornecido pela direção da empresa para a implantação de gestão de segurança na obra e de acordo com as respostas obtidas nos questionários, um total de 9 (nove) entrevistados, cerca de $60 \%$ do público afirmam que a direção da empresa não fornece todo o respaldo necessário para a implantação de gestão de segurança na obra. Somente 06 (seis) pessoas dizem ter o respaldo necessário, ou seja, 40\% das respostas.

Na obra "A" ambos entrevistados afirmaram não receber o respaldo necessário para implantação de gestão de segurança na obra, chegando assim a $100 \%$ do público atingido. Segundo o técnico de segurança a direção dá maior importância à produtividade. Para o Engenheiro de Segurança, o único respaldo fornecido é em relação à aquisição de epi e epc, fator não suficiente para realizar gestão de segurança no canteiro.

Na obra "B" 3 (três) dos entrevistados (o técnico e os dois Engenheiros civis) afirmam receber o respaldo necessário. Já o Engenheiro de segurança argumentou que o respaldo existente é para compra de epi e epc e a liberação das equipes para treinamentos. Assim sendo, contabilizou-se que $75 \%$ dos entrevistados desta obra afirmam receber o respaldo necessário e apenas $25 \%$ diz não receber esse respaldo.

Nas obras "C, E e F" os profissionais do SESMT afirmam não haver respaldo para implantar gestão de segurança. Dentre os motivos relatados, respectivamente: Burocratização, impacto no tempo de execução da obra e falta de suporte técnico. Dessa forma, $100 \%$ dos entrevistados dessas obras confirmam não ter respaldo necessário para implantação de gestão de segurança em suas obras.

Na obra "D", tanto o técnico como o Engenheiro de segurança declaram ter respaldo para implantação de gestão de segurança na obra, totalizando $100 \%$ positivo.

Os entrevistados da obra "G" tiveram opiniões distintas, computando $50 \%$ afirmando ter respaldo e $50 \%$ mencionando a falta desse mesmo respaldo. A técnica de Segurança do trabalho informou a falta de priorização com a segurança no canteiro de obra, já o Engenheiro civil e de segurança afirma receber todo o respaldo necessário da sua diretoria.

Para que haja comprometimento com a segurança nos canteiros de obras, a alta gestão deverá se mostrar presente nesse contexto, não deixando somente essa função a cargo dos empregados, devendo expressar preocupação com a área, para que o pessoal da obra note que a segurança é um ponto positivo da política da empresa. Esta percepção trará motivação para a segurança do trabalho. (CRUZ, 1998).

Na questão de número 9 sobre a ocorrência de acidentes de trabalho, todas as obras pesquisadas informaram controlar as estatísticas dos acidentes de trabalho, e no caso de ocorrências, afirmaram realizar a investigação e consequentemente abertura da CAT.

Segundo Júnior et al (2011), é extremamente necessário implementar na empresa um sistema capaz de identificar, registrar e analisar as causas dos acidentes e quantificar as perdas no canteiro de obra.

Os canteiros onde tiveram ocorrências forneceram as informações necessárias sobre os acidentes de trabalho e após a compilação dos dados podemos verificar que os acidentes típicos ocorrem na sua maioria se comparado aos típicos e as doenças do trabalho ou ocupacionais.

Na obra "A" ocorreram 02 (dois) acidentes do tipo típico, sendo relatado o primeiro acidente por queda de andaime, cuja altura era equivalente a $1,20 \mathrm{mt}$ no momento em que o trabalhador executava alvenaria de vedação; 0 segundo acidente ocorrido foi durante a atividade de abastecimento de material, quando ao lançar um bloco cerâmico o trabalhador acabou acertando a testa de outro trabalhador. 
Na obra "B" ocorreu 01 (um) acidente típico decorrente da falta do uso do epi obrigatório, óculos, onde ao executar o serviço de chapisco com massa, o trabalhador acabou tendo a visão lesionada pela projeção da mistura de cimento e cal.

A obra "E" foi a que mais relatou as ocorrências de acidentes de trabalho, expondo os 05 (cinco) típicos e os 04 (quatro) de trajeto ocorrido com seus trabalhadores. Nos típicos, relatou o técnico de segurança que houve uma queda com diferença de nível, dois acidentes ocasionados por projeção de material na visão e dois acidentes em decorrência do uso inadequado de ferramentas, provocando cortes superficiais. Já os acidentes de trajeto foram dois devido ao uso da bicicleta, uma queda ao sair do ônibus coletivo e um acidente de moto.

A obra "F" registrou 03 (três) acidentes sendo 02 (dois) típicos e 01 (um) de trajeto. Os típicos foram: Uma fratura na mão em decorrência do uso inadequado de furadeira elétrica e o segundo foi um corte na mão devido à manipulação de objeto cortante (faca). 0 de trajeto foi provocado por queda de motocicleta.

As obras C, D e G relataram não ter ocorrido nenhum tipo de acidente de trabalho.

Você sabe qual o maior motivo da ocorrência de acidentes de trabalho na construção civil? Essa foi uma outra pergunta levantada no questionário. A maior parte dos entrevistados, 13 pessoas, equivalente a $86,67 \%$ relatou saber qual o maior motivo para ocorrência de acidentes de trabalho na construção civil. Somente 02 pessoas, $13,33 \%$ do total dizem que gostariam de saber.

Para Cruz (2018) são muitos os fatores da ocorrência de acidentes de trabalho na construção civil, podendo citar: A utilização inadequada ou o não uso dos equipamentos de proteção individual, falta de aptidão do trabalhador para cumprimento de determinadas tarefas, a falta de equipamentos de proteção coletiva, dentre outros. Alguns destes motivos foram relatados pelos profissionais entrevistados conforme abaixo:

De acordo com os representantes da Obra "A" os maiores motivos das ocorrências são:

- A falta de envolvimento efetivo dos gestores;

- A não implementação de ferramentas de prevenção;

- Atitudes inseguras e;

- Condições inseguras.

Segundo Brauer (1994), os acidentes de trabalho são provocados em decorrência das atitudes inseguras, condições inseguras ou pelas duas, tendo o potencial de causar acidentes de trabalho.

Na obra "B" os entrevistados relataram os seguintes motivos:

- Negligência por parte do colaborador em relação às atividades de risco;

- Falta de utilização dos Epi's;

- Falta de análise prévia do risco;

- Falta de envolvimento efetivo dos gestores, pois não bastam somente recursos materiais.

$\mathrm{Na}$ obra "C" o técnico de segurança informou que gostaria de saber qual o maior motivo de acidentes de trabalho, já o Engenheiro de Segurança afirma que a falta de envolvimento e comprometimento das lideranças são os maiores motivos para ele.

Para os profissionais da obra “D”, os maiores motivos são:

- Falta de empenho por parte da direção;

- $\quad$ A falta de prioridade em relação à segurança por parte da alta gestão.

Para o técnico de segurança da obra "E" as informações são as seguintes:

- Falta de uso adequado dos Epi's devido à resistência dos operários em utilizar; 
- Falta de atenção na execução das atividades;

- Preocupação somente com a produtividade.

Na obra "F" foram relatados os seguintes motivos para ocorrência dos acidentes de trabalho:

- Não cumprimento dos procedimentos;

- Falta de segurança por parte do colaborador (Atitudes Inseguras);

- Falta de prioridade por parte da gestão.

Na obra "G" o Engenheiro civil com especialidade em segurança do trabalho relatou que gostaria de saber qual o maior motivo da ocorrência de acidentes de trabalho. Já a técnica de segurança descreveu os seguintes motivos:

- Atitudes fora dos padrões normais de segurança por parte dos operários (Atos Inseguros);

- Condições Inseguras por parte da empresa.

Após explanação acima verifica-se que os maiores motivos para a ocorrência dos acidentes segundo a visão dos entrevistados são: A falta de envolvimento efetivo dos gestores com 33,33\%; Em seguida as Atitudes inseguras com 26,67\% ocupou a segunda opção mais mencionada; Condições inseguras e a Falta de utilização dos Epi's computaram 13,33\% das respostas e ficaram como a terceira opção mais citada; $13,33 \%$ dos entrevistados afirmaram que gostariam de saber quais os maiores motivos das ocorrências. Seis situações tiveram $6,67 \%$ dos registros pelos entrevistados, são elas: A não implementação de ferramentas de prevenção, a Falta de análise prévia do risco, a Falta de empenho por parte da direção, Falta de atenção na execução das atividades, Preocupação somente com a produtividade e Não cumprimento dos procedimentos. A Figura 11 mostra o percentual da visão geral dos entrevistados em relação a ocorrências de acidentes de trabalho na construção civil.

Figura 11: Gráfico com a visão geral dos entrevistados em relação a ocorrências de acidentes de trabalho na construção civil.

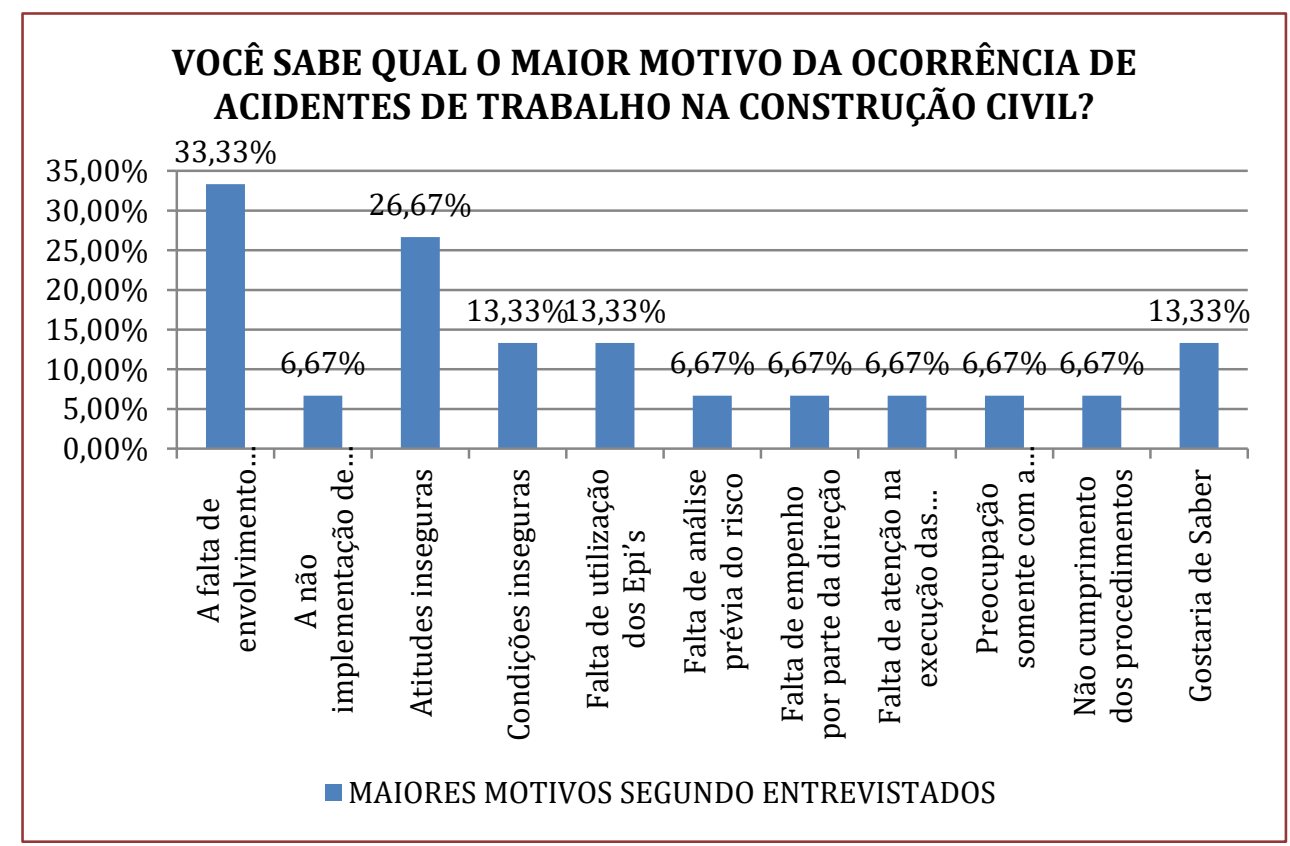

Fonte: Elaborado pelo autor da pesquisa (2018) 
Sobre percepção de riscos, pode-se observar na Figura 12 que a maior parte dos entrevistados relatou que os operários das suas obras têm uma boa percepção de riscos, mais exatos 53,33\% descreveram essa informação, 40\% disseram que os operários não possuem uma boa percepção de riscos, número muito alto em se tratando de conhecer os riscos a que estão expostos e 6,67\% não souberam informar.

De acordo com Meneghetti (2010) as empresas devem procurar conhecer o grau de percepção de riscos dos seus trabalhadores devido aos níveis de formação escolar dessa categoria e da grande rotatividade de pessoal, reafirmando que esse aspecto é importante para a prevenção dos acidentes de trabalho nesse setor.

Na obra "A" foi exposto que os trabalhadores não possuem uma boa percepção de riscos, segundo o Engenheiro de segurança a equipe possui vícios e teve a cultura de prevenção prejudicada devido a atitudes das lideranças do canteiro. Já o Técnico de segurança reafirma a falta de percepção mesmo aplicando os DDS e treinamentos na obra. Com esses dados verifica-se $100 \%$ das respostas referente a falta de percepção de riscos nesse canteiro de obras.

Na obra "B" o técnico informou que os operários possuem uma boa percepção de riscos, pois sabem o que devem e o que não devem fazer devido às instruções que lhe são dadas. Já os Engenheiros Civis, especialistas na área de segurança do trabalho tiveram opiniões diferentes, 01 (um) disse que os operários não possuem uma boa percepção dos riscos e o outro Engenheiro disse que os operários dispõem sim de uma boa percepção, ainda assim não seguem as orientações. Já o Engenheiro de Segurança relata a boa percepção por parte dos operários deste canteiro reiterando que é devido à aplicabilidade de treinamentos, palestras e DDS. Evidencia-se na obra "B" um expressivo percentual de 75\% afirmando que a mão de obra tem sim uma boa percepção dos riscos e $25 \%$ diz que os operários dessa obra não tem uma boa percepção.

Na obra "C" o técnico de segurança foi recém-contratado e não dispõe ainda dessa análise, não sabendo informar. 0 Engenheiro de segurança informa que pelo baixo efetivo e pelo início da obra já identifica uma boa percepção por parte dos presentes ao canteiro. Não souberam informar $50 \%$ e $50 \%$ afirma identificar uma boa percepção dos operários deste canteiro.

0 representante da obra " $\mathrm{D}$ " enfatizou que ministra treinamentos e demonstra na prática aos trabalhadores a forma correta de se proteger, assim afirmando que a equipe tem uma boa percepção dos riscos. 0 Engenheiro de segurança seguiu a mesma linha de resposta e deu como positivo a percepção naquele canteiro, computando assim, 100\% das respostas voltadas a uma boa percepção nesta obra.

Na obra "E" $100 \%$ dos entrevistados diz que os trabalhadores tem uma boa percepção dos riscos. 0 técnico de segurança informa que existe com certeza uma boa percepção dos riscos por parte dos seus trabalhadores devido aos treinamentos contínuos que são ministrados por ele.

O principal motivo da falta de percepção de riscos dos trabalhadores da obra "F" se dá, segundo palavras do técnico de segurança do trabalho, por falta de conhecimento das normas. Já o Engenheiro de segurança garante que as ações inseguras dos operários demonstram a baixa percepção de riscos nesse canteiro. Com essas respostas, vemos $100 \%$ do público afirmando a falta de percepção dos riscos dos trabalhadores desse empreendimento.

Segundo Colombo (2009) é devido à falta de conhecimento por parte dos trabalhadores, pressa para entregar o serviço contratado e ausência ou deficiência nos planejamentos das atividades diárias, que os canteiros de obras tornam-se um lugar com grandes possibilidades de ocorrências de acidentes do trabalho.

Na obra "G" as respostas foram divididas, tendo como boa percepção a resposta da técnica de segurança que vincula as orientações dadas como um bom motivo para a resposta. 0 Engenheiro civil e de segurança disse que apesar de treinamentos e DDS ainda não vê uma boa percepção nesse canteiro devido à existência de operários desatentos e dos riscos de acidentes provocados.

Com as respostas obtidas na obra "G" vê-se que 50\% não vê uma boa percepção de riscos por parte dos trabalhadores daquele canteiro e os demais 50\% afirma que existe sim uma boa percepção, pois, são ministrados treinamentos frequentes e Diálogo Diário de Segurança (DDS) todos os dias com a mão de obra, com o intuito de alertar os trabalhadores dos riscos existentes no ambiente laboral, ressaltando ainda a técnica de segurança da obra, que após essas ações de instruções e treinamentos frequentes os trabalhadores passaram a ter uma maior atenção na execução das atividades diárias assim, por isso, afirma que acredita em uma boa percepção dos trabalhadores da sua obra. 
Figura 12: Gráfico com panorama geral dos entrevistados sobre a percepção de riscos dos operários nas obras.

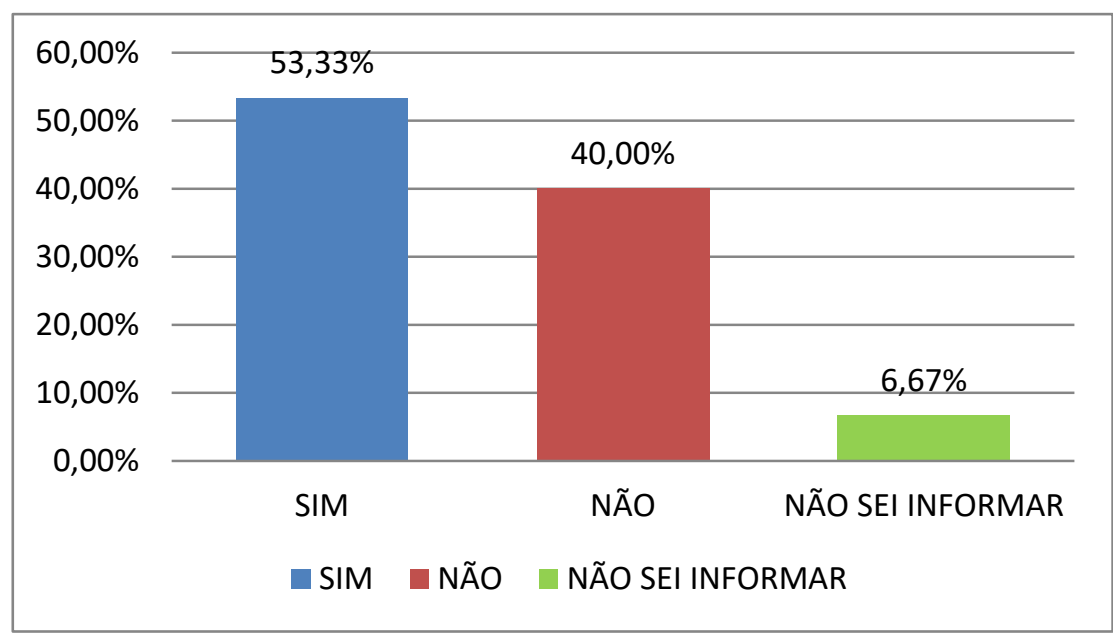

Fonte: Elaborado pelo autor da pesquisa (2018).

Existem diversos tipos de agentes de riscos na área da construção civil que presentes no ambiente de trabalho podem provocar lesões nos trabalhadores devido a sua natureza, concentração ou intensidade e tempo de exposição. (NR-9, 2017).

De acordo com a NR-9 (2017) são considerados riscos ambientais os agentes físicos, químicos e biológicos. Nas obras visitadas, além destes riscos, foram evidenciados e relatados nas respostas dos questionários conforme abaixo a presença dos ergonômicos e de acidentes, que por meio de registros fotográficos no item 3.2 desta pesquisa, podemos visualizar alguns dos mencionados pelos entrevistados quando perguntados quais seriam os riscos mais comuns nas suas obras.

Na obra "A" segundo os entrevistados, os riscos mais presentes são:

- Físicos - Ruídos e vibrações provocados por máquinas e equipamentos;

- Químicos - Contato com poeira e manipulação de cimento, cal, tintas e solventes;

- Ergonômicos - Postura Inadequada e trabalho repetitivo;

- Acidentes - Risco de queda de altura, queda do mesmo nível, queda de materiais sobre pessoas e choque elétrico.

Na obra "B" os riscos relatados pelo técnico e pelo Engenheiro de segurança foram:

- Físicos - Ruídos e vibrações provocados por máquinas e equipamentos;

- Químicos - Contato com poeira e manipulação de cimento, cal, gesso, tintas e solventes;

- Biológicos - Bactérias devido uso de banheiros coletivos;

- Ergonômicos - Postura Inadequada, levantamento de peso e trabalho repetitivo;

- Acidentes - Risco de queda de altura, queda do mesmo nível, queda de materiais sobre pessoas e choque elétrico.

Em decorrência do estágio inicial da obra “C”, os entrevistados relataram os seguintes riscos acompanhados de seus agentes:

- Físicos - Ruídos e vibrações provocados pelo motor das máquinas;

- Químicos - Exposição à Poeira;

- Acidentes - Risco de queda de altura, choque elétrico, lesões (mãos, dedos, pés, etc.) devido à manipulação de ferramentas manuais.

Na obra "D”, os riscos e agentes ambientais foram relatados pelos entrevistados como:

- Físicos - Ruídos;

- Químicos - Manipulação de cimento e argamassa; 
- Biológicos - Devido contato com materiais diversos (areia, entulho, etc.) e devido uso de banheiros coletivos;

- Ergonômicos - Levantamento de peso (sacos de cimento);

- Acidentes - Risco de quedas e choque elétrico.

Na obra "E" o técnico de segurança descreveu os riscos e seus principais agentes presentes na

obra:

- Físicos - Ruído;

- Químicos - Contato com poeira;

- Ergonômicos - Postura Inadequada e levantamento de peso (caixas de cerâmica);

- Acidentes - Risco de quedas.

Na obra "F" foram caracterizados os riscos e seus agentes conforme abaixo:

- Físicos - Ruídos, vibrações e radiação não ionizante;

- Químicos - Poeiras, névoas e contato com cimento;

- Biológicos - Bactérias e Vírus;

- Ergonômicos - Postura inadequada;

- Acidentes - Queda de altura e choque elétrico.

Na obra "G" os riscos relatados pelos entrevistados foram:

- Físicos - Ruídos, Stress térmico, radiação não ionizante e calor;

- Químicos - Uso de aditivos químicos, exposição à poeira, tintas e soldas;

- Biológicos - Bactérias presentes nos banheiros e fungos;

- Ergonômicos - Postura Inadequada, carregamento de peso (cimento, caixas, etc.);

- Acidentes - Risco de queda de altura devido à falta de epc's, queda de andaimes e choque elétrico.

Sobre o questionamento referente ao que pode influenciar na falta ou na aplicabilidade eficaz de gestão de riscos nas obras, foram lançados seis itens na questão de número treze para que os entrevistados demonstrassem sua visão em relação às principais dificuldades encontradas nas empresas.

Com 93,33\% o item "Preocupação dos líderes somente com as metas e produtividade" foi o mais mencionado pelos entrevistados, ao todo 14 (quatorze) pessoas disseram ser essa é a maior dificuldade para implantação e aplicabilidade de gestão de riscos nas empresas.

0 segundo item foi referente às "Questões culturais dos operários" que ficou com $80 \%$ das opiniões, mais especificamente 12 (doze) entrevistados mencionaram esse item em decorrência das várias opiniões destacadas em questão anterior sobre as ações de insegurança, que segundo eles, são causadas na maioria das vezes pelo próprio trabalhador nos canteiros de obras;

0 terceiro item foi a "Falta de apoio/interesse por parte da diretoria/lideranças da empresa", citado por 10 (dez) pessoas, teve $66,67 \%$ das escolhas dos entrevistados. Foi também mencionado anteriormente que um dos maiores motivos dos acidentes de trabalho em obras se dá devido à falta de apoio e interesse por parte das lideranças.

A "falta de flexibilidade em aceitar mudanças de atitude" teve 09 (nove) indicações, sendo o quarto item mais citado pelos entrevistados chegando a $60 \%$ das escolhas.

Em seguida, os dois últimos itens citados foram a "Falta de políticas e procedimentos obrigatórios por parte das empresas" com 05 (cinco) indicações, equivalente a 33,33\% e a "Falta de investimento e interesse por parte das empresas" com 01 (uma) indicação, totalizando somente 6,67\% das indicações.

A seguir, a Figura 13 com o gráfico para melhor ilustrar os números dessa pesquisa: 
Figura 13: Gráfico com a percepção geral dos entrevistados sobre o que pode influenciar na falta ou na aplicabilidade eficaz de gestão de riscos nas obras/empresas.

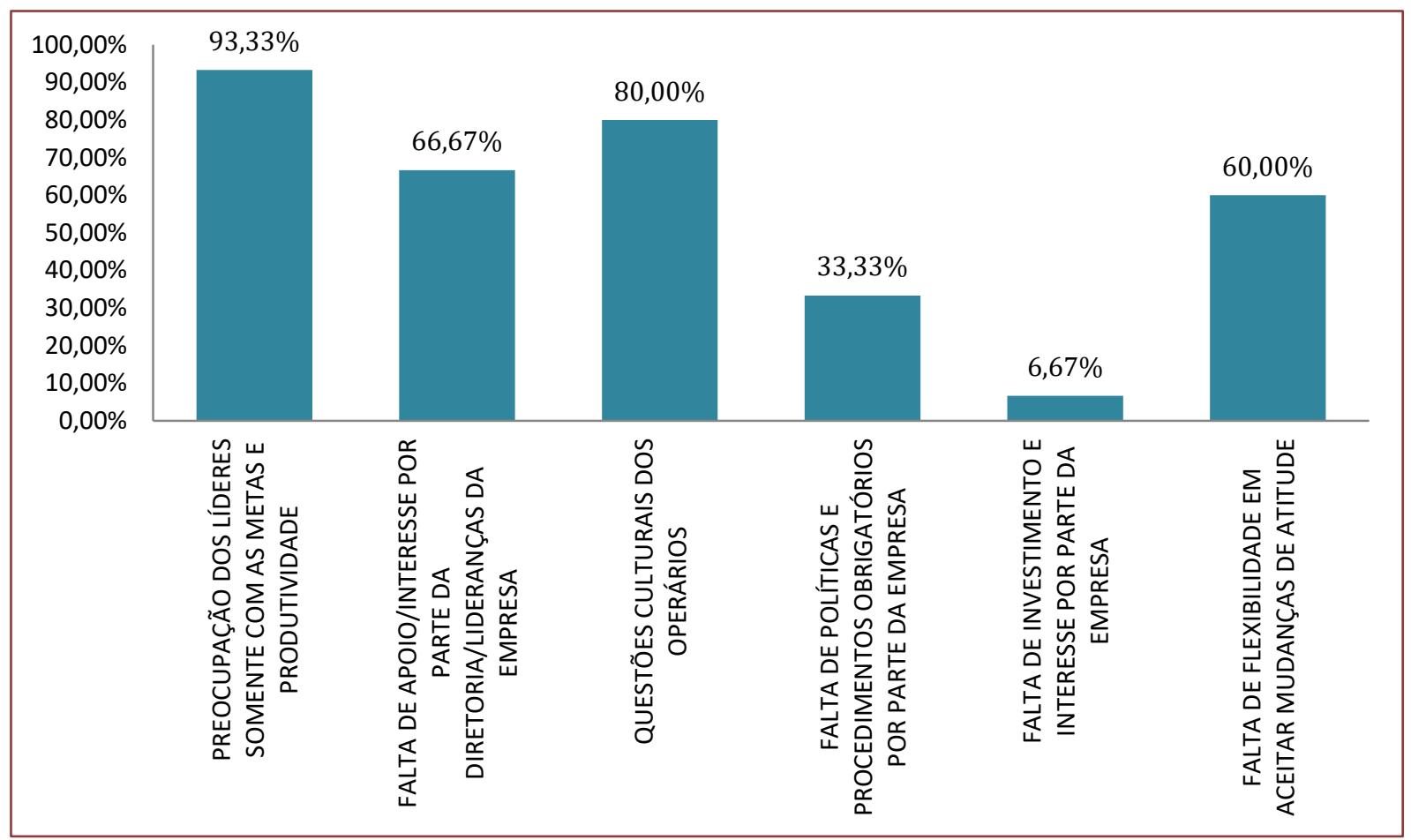

Fonte: Elaborado pelo autor da pesquisa (2018)

\subsection{FERRAMENTA PROPOSTA PARA APLICAÇÃO NAS OBRAS ANALISADAS}

Após analisar os cenários de riscos por meio dos dados obtidos, chegou-se à definição da ferramenta mais adequada para aplicação nas obras pesquisadas.

Com a observação dos cenários de riscos registrados em cada empreendimento tornou-se possível identificar os cenários acidentais e com complementação das informações dos órgãos oficiais dos dados estatísticos de cada canteiro levantado no questionário aplicado, também foi possível definir as categorias de frequência e severidade, assim, com a aplicação da matriz de aceitabilidade, encontrou-se os riscos de cada cenário.

Após realizar análise de todas as ferramentas de gestão de risco possíveis de serem aplicadas nas obras chegou-se à conclusão de que a mais adequada seria a Análise Preliminar de Perigos.

\section{CONCLUSÃO}

Conclui-se que o presente trabalho apresentou em linhas gerais, um panorama da Construção Civil em Sergipe, no tocante aos requisitos necessários para a segurança do trabalho em obras. A pesquisa deu a dimensão da importância da utilização de programas e ferramentas de prevenção de riscos, como também das dificuldades encontradas em algumas obras na implantação desses meios de contenção de acidentes.

As obras pesquisadas, em sua totalidade demonstraram ter problemas com as técnicas de prevenção de riscos, foi possível perceber nas visitas in loco que poucas delas possuem de fato algum tipo de programa. 0 que pode-se encontrar foram tentativas de minimizar os riscos, na tentativa de obedecer minimamente ao menos a legislação obrigatória.

Chegou-se ao método proposto através da pesquisa de campo realizada nas sete obras visitadas in loco para aplicação de questionário desenvolvido a partir da proposta de cada empreendimento, bem como os registros fotográficos foram de grande valia na identificação dos riscos encontrados em cada uma das obras, o que ficou perceptível que ainda precisa-se dar passos mais firmes em relação ao tema abordado. 
Diante da falta de aplicabilidade dessas ferramentas nas obras visitadas, e após explanação básica sobre cada uma das constantes nesse trabalho, aos responsáveis pelas obras acerca da implantação da Análise Preliminar de Perigos (APP), chegou-se à conclusão que o uso da ferramenta proposta teria uma resposta positiva no controle e diminuição de riscos e acidentes.

Por fim sugere-se que para os próximos trabalhos sejam realizados projetos de intervenção aplicando uma das ferramentas em canteiros de obras diferentes.

\section{REFERÊNCIAS}

[1] ALBERTON, Anete. Uma Metodologia para auxiliar no gerenciamento de riscos e na seleção de alternativas de investimentos de segurança. Dissertação (Mestrado em Engenharia de Produção) Programa de Pós-Graduação em Engenharia de Produção, Universidade Federal de Santa Catarina. Florianópolis, 1996. Disponível em: https://repositorio.ufsc.br/xmlui/bitstream/handle/123456789/76462/104023.pdf?sequence=1\&isAllo wed=y>. Acesso em 01/05/2018.

[2] Alencar \& Schmitz (2009) - ALENCAR, A. J., \& SCHMITZ, E.A. Análise de risco em gerência de projetos. 2. ed. Rio de Janeiro, Brasport, 2009.

[3] ALUMINUM COMPANY OF AMERICA (ALCOA). Accidents: Nature, Causes and Results. Pittsburgh, 1978.

[4] AMORIM, E. L. C. de. Ferramentas de Análise de Risco. Apostila do curso de Engenharia Ambiental da Universidade Federal de Alagoas, CTEC, Alagoas: 2010. Disponível em: < http://www.ctec.ufal.br/professor/elca/Apostila\%20de\%20ferramentas $\% 20 \mathrm{de} \% 20$ an\%C3\%A1lise $\% 20$ de\%20risco.doc. >. Acesso em: 09 Abr. 2018.

[5] ARAÚJO, N. M. C. Proposta de Sistema de Gestão da Segurança e Saúde no Trabalho, baseado na OHSAS 18001, para empresas construtoras de edificações verticais. Tese (Doutorado em Engenharia de Produção). Universidade Federal da Paraíba, João Pessoa, 2002. Disponível em: <http://cpnnr18.com.br/uploads/documentos-gerais/tese_versocd.pdf.pdf.>. Acesso em: 13 de Abril de 2018.

[6] ASSOCIAÇÃO BRASILEIRA DE NORMAS TÉCNICAS. ABNT NBR ISO 31000: Gestão de riscos — Princípios e diretrizes. Rio de Janeiro - Rj, 2009. 24 p.

[7] ASSOCIAÇÃO BRASILEIRA DE NORMAS TÉCNICAS. ABNT NBR ISO/IEC 31010: Gestão de riscos — Técnicas para o processo de avaliação de riscos. Rio de Janeiro - Rj, 2012. 96 p.

[8] ASSOCIAÇÃO BRASILEIRA DE NORMAS TÉCNICAS. ABNT NBR 5413: Iluminação de Interiores. Rio de Janeiro - Rj, 1992. 13 p. Disponível em: < http://ftp.demec.ufpr.br/disciplinas/TM802/NBR5413.pdf >. Acesso em: 23 Mai. 2018.

[9] ASSOCIAÇÃO BRASILEIRA DE NORMAS TÉCNICAS. NR 6: EQUIPAMENTOS DE PROTEÇÃO INDIVIDUAL. $\quad$ S.l.: $\quad$ Sem $\quad$ Editora, 2017. 8 p. <http://trabalho.gov.br/images/Documentos/SST/NR/NR6.pdf >. Acesso em: 12 Abr. 2018.

[10] ASSOCIAÇÃO BRASILEIRA DE NORMAS TÉCNICAS. NR 7: - PROGRAMA DE CONTROLE MÉDICO DE SAÚDE OCUPACIONAL. S.l.: Sem Editora, 2013. 16 p. Disponível em: < http://trabalho.gov.br/images/Documentos/SST/NR/NR7.pdf>. Acesso em: 13 mai. 2018.

[11] ASSOCIAÇÃO BRASILEIRA DE NORMAS TÉCNICAS. NR 9: PROGRAMA DE PREVENÇÃO DE RISCOS

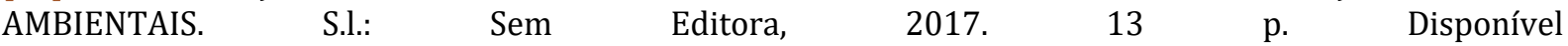
em:<http://trabalho.gov.br/images/Documentos/SST/NR/NR09/NR-09-2016.pdf>. Acesso em: 13 Abr. 2018.

[12] ASSOCIAÇÃO BRASILEIRA DE NORMAS TÉCNICAS. NR 11: TRANSPORTE, MOVIMENTAÇÃO, ARMAZENAGEM E MANUSEIO DE MATERIAIS. S.l.: Sem Editora, 2016. 10 p. Disponível em: <http://trabalho.gov.br/images/Documentos/SST/NR/NR11.pdf>. Acesso em: 14 mai. 2018.

[13] ASSOCIAÇÃO BRASILEIRA DE NORMAS TÉCNICAS. NR 12: SEGURANÇA NO TRABALHO EM MÁQUINAS E EQUIPAMENTOS. S.l.: Sem Editora, 2018. 114 p. Disponível em: <http://www.trabalho.gov.br/images//Documentos/SST/NR/NR12/NR-12.pdf>. Acesso em: 11 Mai. 2018. 
[14] ASSOCIAÇÃO BRASILEIRA DE NORMAS TÉCNICAS. NR 15: ATIVIDADES E OPERAÇÕES INSALUBRES. S.l.: Sem Editora, 2014. 82 p. Disponível em: < http://trabalho.gov.br/images/Documentos/SST/NR/NR15/NR-15.pdf>. Acesso em: 11 Mai. 2018.

[15] ASSOCIAÇÃO BRASILEIRA DE NORMAS TÉCNICAS. NR 17: ERGONOMIA. S.l.: Sem Editora, 2007. 14 p. Disponível em: < http://trabalho.gov.br/images/Documentos/SST/NR/NR17.pdf>. Acesso em: 11 Mai. 2018.

[16] ASSOCIAÇÃO BRASILEIRA DE NORMAS TÉCNICAS. NR 18: CONDIÇÕES E MEIO AMBIENTE DE TRABALHO NA INDÚSTRIA DA CONSTRUÇÃO. S.l.: Sem Editora, 2015. 66 p. Disponível em: $<$ http://trabalho.gov.br/images/Documentos/SST/NR/NR18/NR18atualizada2015.pdf>. Acesso em: 13 Abr. 2018.

[17] ASSOCIAÇÃO BRASILEIRA DE NORMAS TÉCNICAS. NR 35: TRABALHO EM ALTURA. S.l.: Sem Editora, 2016. 12 p. Disponível em: <http://trabalho.gov.br/images/Documentos/SST/NR/NR35/NR-352016.pdf>. Acesso em: 14 Mai. 2018.

[18] BASTOS, A. L. A. FMEA (Failure Mode and Effect Analysis) Como Ferramenta de Prevenção da Qualidade em Produtos e Processos - Uma Avaliação da Aplicação em um Processo Produtivo de Usinagem de Engrenagem. Artigo (Congresso) - XXVI ENEGEP, Fortaleza, Ceará, 2006.

[19] BELLO J. L. P. Metodologia Científica. Universidade Veiga de Almeida - UVA Rio de Janeiro - 2009. Disponível em: http://www.insaeos.org.br/images/phocadownload/Comiss\%C3\%A3o_TCC/Fac_UVA2009.pdf<. Acesso em: 08 de Maio de 2018.

[20] BRASIL. MINISTÉRIO DO TRABALHO, PDET - PROGRAMA DE DISSEMINAÇÃO DAS ESTATÍSTICAS DO TRABALHO. Disponível em: http://pdet.mte.gov.br/index.php/rais > Acesso em: 11 de abr. de 2018.

[21] BRASIL. PORTARIA N. 25, DE 29 DE DEZEMBRO DE $1994 . \quad$ Disponível em< https://www.agencia.cnptia.embrapa.br/Repositorio/Portaria+n.+25+SSST+MTb+29+dezembro+1994+A prova+a+NR+9+sobre+o+Programa+de+Prevencao+e+riscos+ambientais_000gvpl14yq02wx7ha0g934vg rnn5ero.PDF > Acesso em 20 Abr. 2018.

[22] BRASIL. Constituição (1991). Lei $\mathrm{N}^{\circ}$ 8.213, de 24 de Julho de 1991. Disponível em http://www.planalto.gov.br/ccivil_03/leis/L8213cons.htm> Acesso em: 09 de abril de 2018.

[23] BRASIL. Ministério do Trabalho. Secretaria de Segurança e Saúde no Trabalho. Campanha nacional de combate aos acidentes de trabalho (CANCAT). Brasília, 1996.

[24] BRAUER. R. L. safety and Health for engineers. New York: Van Nonstrand Reinhold, 1994.

[25] (BSI), Britsh Standards Instituition. Série da Avaliação da Saúde e da Segurança do Trabalho. OHSAS 18001 (2007). S.l: Editora Não Identificada, 35 p. Disponível em: $<$ https://comum.rcaap.pt/bitstream/10400.26/7319/2/Anexo I OHSAS180012007_pt.pdf>. Acesso em: 16 Abr. 2018.

[26] CALLERI, Carla. Auxílio-doença acidentário: reflexos no contrato de trabalho. São Paulo: LTr., 2007.

[27] CARDELLA, Benedito. Segurança no Trabalho e Prevenção de Acidentes, Uma abordagem Holística: Segurança Integrada à Missão Organizacional com produtividade, Qualidade, Preservação Ambiental e Desenvolvimento de Pessoas. São Paulo: Atlas, 1999. 254 p

[28] CARDELLA, Benedito. Segurança no trabalho e prevenção de acidentes: Uma abordagem holística: segurança integrada à missão organizacional com produtividade, qualidade, preservação ambiental e desenvolvimento de pessoas / Benedito Cardella. - 1 ed. - São Paulo: Atlas, 2013.

[29] CBIC, Agência. Acidentes na construção tiveram queda de 27\% em cinco anos. 2018. Disponível em: <https://cbic.org.br/acidentes-na-construcao-tiveram-queda-de-27-em-cinco-anos/>. Acesso em: 09 maio 2018.

[30] CHELL, E. (1998), Critical Incident Technique, in Qualitative Methods and Analysis in Organizational Research: A Practical Guide. Gillian Simon \& Catherine Cassell, Thousand Oaks, pp. 51-72.

[31] CICCO, Francesco de; FANTAZZINI, Mario Luiz. Tecnologias Consagradas de Gestão de Riscos. 2. ed. São Paulo: Risk Tecnologia, 2003. 200 p. Disponível em: $<$ http://www.auditoriainterna.ufscar.br/arquivos/tecnologias-consagradas-de-gestao-de-riscos/view>. Acesso em: 21 Abr. 2018. 
[32] COLOMBO, Caroline Bitencourt. 0 acidente do trabalho e a responsabilidade civil do empregador. 2009. 84f. Monografia (Curso de Direito) - Universidade Federal de Santa Catarina, Florianópolis, 2009. Disponível em: http://www.egov.ufsc.br/portal/sites/default/files/anexos/33750-44002-1PB.pdf $>$.Acesso em 12 de Abr. de 2018.

[33] COSTA, Analice Trindade. Indicadores de acidentes de trabalho em obras da construção civil no Brasil e na Bahia. 2009. 51f. Monografia (Curso de Engenharia Civil) - Universidade Estadual de Feira de Santana, Feira de Santana, Bahia. Disponível em: http://civil.uefs.br/DOCUMENTOS/ANALICE\%20TRINDADE\%20COSTA.pdf>. Acesso em: 11 de Abr. de 2018.

[34] COSTA, M. A. F. da; COSTA, M. de F. B. da; MELO, N. S. F. de 0., Biossegurança. Livraria Santos Editora Ltda, São Paulo - SP, 2014. ISBN: 85-7288-228-6.

[35] CRUZ, S. M. S. Gestão de segurança e saúde ocupacional nas empresas de construção civil, 113p Dissertação (mestrado) - Universidade Federal de Santa Catarina Florianópolis, 1998. Disponível em: https://repositorio.ufsc.br/bitstream/handle/123456789/77501/142121.pdf?sequence=1.<. Acesso em: 21 de Maio de 2018.

[36] CRUZ, Sandro Iury Valverde Lima da. Gerenciamento de Riscos. Aracaju: Faculdade Pio Décimo, Núcleo de Pós-graduação e Extensão, Curso de Engenharia de Segurança do Trabalho, 2014. 195 slides, color.

[37] CRUZ, Sandro Iury Valverde Lima da. PCMAT - Programa de Condições e Meio Ambiente do Trabalho na Indústria da Construção. Obra: Edifício Jardim Europa Medical Center. Aracaju: ., 2018. 216 p.

[38] De CICCO, F. \& FANTAZZINI, M.L. Introdução à engenharia de segurança de sistemas. FUNDACENTRO São Paulo, 4⿳⺈冂䒑 ed., 1994.

[39] De CICCO, F. \& FANTAZZINI, M.L. Os riscos empresariais e a gerência de riscos. Revista Proteção. Suplemento especial n.1, Novo Hamburgo, n.27, fevereiro/março, 1994.

[40] DE CICCO, F. Manual sobre sistemas de gestão da segurança e saúde no trabalho: volume m. São Paulo: Risk tecnologia, junho, 1999.

[41] DELGADO, Maurício Godinho. Curso de Direito do Trabalho. 9. ed. São Paulo: LTr, 2011.

[42] DINIZ, Jadir Ataíde Júnior. Segurança do Trabalho em obras de Construção Civil dissertação (graduação) Universidade Regional do Noroeste do Estado do Rio Grande do Sul, Rio Grande do Sul, 2002. Disponível em: http://www.projetos.unijui.edu.br/petegc/wp-content/uploads/tccs/tcctitulos/2002/Seguranca_do_Trabalho_em_Obras_de_Construcao_Civil_Santa_Rosa.pdf $>$. Acesso em: 22 de Abr. de 2018.

[43] ESTATíSTICA, IBGE - Instituto Brasileiro de Geografia e. População. 2017. Disponível em: $<$ https://cidades.ibge.gov.br/brasil/se/aracaju/panorama>. Acesso em: 05 de maio de 2018.

[44] Ferreira Aurélio Buarque de Holanda. Dicionário Aurélio da Língua Portuguesa / Aurélio Buarque de Holanda Ferreira; Coordenação Marina Baird Ferreira, Margarida dos Anjos. - 5. Ed. - Curitiba: Positivo, 2010. $2272 \mathrm{p}$.

[45] FERREIRA E. A. M. Metodologia para elaboração do projeto do canteiro de obras de edifício. 1998. 338 f. Tese (Doutorado) - Escola Politécnica, Universidade de São Paulo, 1998. Disponível em: https://docente.ifrn.edu.br/valtencirgomes/disciplinas/projeto-e-implantacao-de-canteiro-deobras/artigo_metodologia-para-implantacao-do-canteiro-de-obra>. Acesso em: 06 de Abr. de 2018.

[46] FLANAGAN, J. C. A técnica do incidente crítico. Arquivo Brasileiros de Psicologia Aplicada, Rio de Janeiro, v. 25, n. 2, p. 99- 141, abr./jun. 1973.

[47] GRANDI, Sônia Lemos Desenvolvimento da Indústria da construção no Brasil: mobilidade e acumulação do capital e força de trabalho. 1985. 121f. Tese (Doutorado em Filosofia, Letras e Ciências Humanas) - Universidade de São Paulo, São Paulo.

[48] Guia para gestão de segurança nos canteiros de obra: orientação para prevenção dos acidentes e para o cumprimento das normas de SST / Coordenação Roberto Sérgio Oliveira Ferreira. - Brasília, DF: CBIC, 2017. 264 p. : il. ; color. Disponível em: >. https://cbic.org.br/wpcontent/uploads/2017/11/Guia_para_gestao_seguranca_nos_canteiros_de_obras_2017.pdf >. Acesso em: 22 de Abr. de 2018. 
[49] KAO, C. S; LAI, W. H; CHUANG, T. F; LEE, J. C. Safety culture factors, group differences, and risk perception in five petrochemical plants. Process Safety Progress, USA, v.27, n.2, p. 145-152, jun.2008.

[50] IIDA, I. Ergonomia Projeto e Produção. São Paulo: Edgard Blucher, 2014.

[51] LIMA JÚNIOR, Jófilo Moreira; VALCÁRCEL, Alberto López; DIAS, Luis Alves. Segurança e Saúde no Trabalho da Construção: experiência brasileira e panorama internacional: (OIT). São Paulo: Editora Não Identificada, $2005 . \quad 74 \quad$ p. $\quad$ Disponível <http://www.fundacentro.gov.br/arquivos/projetos/proesic/Artigos Outros/2005_05_OIT_DOC_TRAB_200.pdf>. Acesso em: 23 Abr. 2018.

[52] MARCHETTI, Ermano. LEGISLAÇÃO DE SEGURANÇA E MEDICINA NO TRABALHO: Manual Prático - FIESP/ CIESP (2003). Disponível em: < http://www.fiesp.com.br/indices-pesquisas-epublicacoes/manual-legislacao-em-seguranca-e-medicina-do-trabalho/>. Acesso em 04 de abril de 2018.

[53] MEDEIROS, José Alysson Dehon Moraes; RODRIGUES, Celso Luiz Pereira. A existência de riscos na indústria da construção civil e sua relação com o saber operário. Paraíba: PPGEP/UFPB, 2009.

[54] MELO JUNIOR, Abelardo da Silva et al. Higiene e Segurança do Trabalho. Rio de Janeiro: Elsevier, 2011. $419 \mathrm{p}$.

[55] MENEGUETTI, A. A. A importância da auditoria comportamental para a prevenção de acidentes na indústria petroquímica. 2010.172f. Dissertação (Mestrado em Sistemas de Gestão)-Centro Tecnológico, Universidade Federal Fluminense, Niterói, 2010. Disponível em: < http://www.bdtd.ndc.uff.br/tde_arquivos/14/TDE-2010-11-04T123445Z-

2679/Publico/Dissertacao\%20\%20\%20Alexander\%20Meneghetti.pdf >. Acesso em 10 de abril de 2018.

[56] MICHEL, Oswaldo. Acidentes do Trabalho e Doenças Ocupacionais. 2. ed. rev., ampl. São Paulo: Ltr, 2001.

[57] MPT. Brasil é quarto lugar no ranking mundial de acidentes de trabalho. 2018. Disponível em: <http://portal.mpt.mp.br/wps/portal/portal_mpt/mpt/sala-imprensa/mpt+noticias/7441f527-ad534a0a-901f-66e40f1a1cae>. Acesso em: 12 abr. 2018.

[58] NASCIMENTO, Ana Maria A. do. ROCHA, Cristiane Gama. SILVA, Marcos Eduardo SILVA, Renata da. CARABETE, Roberto Wagner. A Importância do Uso de Equipamentos de Proteção na Construção Civil. Escola Técnica Estadual Martin Luther King - São Paulo, 2009.

[59] OLIVEIRA, S. G. Proteção jurídica à saúde do trabalhador. São Paulo: LTr, 1998.

[60] PASTORE, José. 0 custo dos acidentes e doenças do trabalho no Brasil. 2011. Disponível em: <http://www.josepastore.com.br/artigos/rt/rt_320.htm>. Acesso em: 09 maio 2018.

[61] RINALDI, A. A importância da comunicação de risco para as organizações. 2007.130f. Dissertação (Mestrado em gestão integrada em saúde do trabalho e meio ambiente) - Centro Universitário SENAC Campus Santo Amaro, São Paulo, 2007.

[62] SAMPAIO, José Carlos de Arruda. PCMAT: Programa de Condições e Meio Ambiente do Trabalho na Indústria da Construção. São Paulo: Pini, SINDUSCON/SP, 1998.

[63] SAURIN T. A.; FORMOSO C. T. Avaliação da aplicação da NR-18 em canteiro de obras. In: ENCONTRO NACIONAL DE ENGENHARIA DE PRODUÇÃO. 20., 2000, Anais... São Paulo. 2000. Disponível em: . Acesso em: 23 mai 2018.

[64] SELVA, Jean Fernando. A ação regressiva do Instituto Nacional do Seguro Social (INSS) em face do empregador nos casos de acidente de trabalho. 2010. 70f. Monografia (Curso de Direito) - Universidade Comunitária da Região de Chapecó, 2010. Disponível em: http://livrozilla.com/doc/1150858/monografiacompleta--para-entrega>. Acesso em 01/05/2018.

[65] SILVA, André Luiz Cabral da. A Segurança do Trabalho Como Uma Ferramenta Para a Melhoria da Qualidade. 2011. Disponível em: http://cascavel.cpd.ufsm.br/tede/tde_busca/arquivo.php?codArquivo=4007. Acesso em 23 de março de 2014.

[66] SILVA, Jodeci Souza da. PCMAT - Programa de Condições e Meio Ambiente do Trabalho na Indústria da Construção. Obra: Duo Residence. Aracaju:., 2017. 68 p. 
[67] SISTEMA DE GESTÃo VOTORANTIM. Manual do Observador. 1.ed. Juiz de Fora: VOTORANTIM METAIS, 2005.

[68] SOCIAL, Previdência. ANUÁRIO ESTATÍSTICO DA PREVIDÊNCIA SOCIAL. 2015. AEPS - 2015. Disponível em: http://www.previdencia.gov.br/wp-content/uploads/2015/08/AEPS-2015-FINAL.pdf >. Acesso em: 08 Abr. 2018.

[69] SOCIAL, Previdência. ANUÁRIO ESTATÍSTICO DA PREVIDÊNCIA SOCIAL. 2016. AEPS - 2016. Disponível em: http://www.previdencia.gov.br/wp-content/uploads/2018/01/AEPS-2016.pdf>. Acesso em: 08 Abr. 2018.

[70] Tesfamariam et al. (2010) - TESFAMARIAM S.; SADIQ R.; NAJJARAN H. Decision Making Under Uncertainty-An Example for Seismic Risk Management. Risk Analysis, vol. 30 (1). p 78-94 2010.

[71] VIEIRA, Sebastião Ivone (coord.) - Manual de saúde e segurança do trabalho: segurança, higiene e medicina do trabalho, volume3 / Sebastião Ivone Vieira. - São Paulo: - LTR, 2006. 
AUTORES 


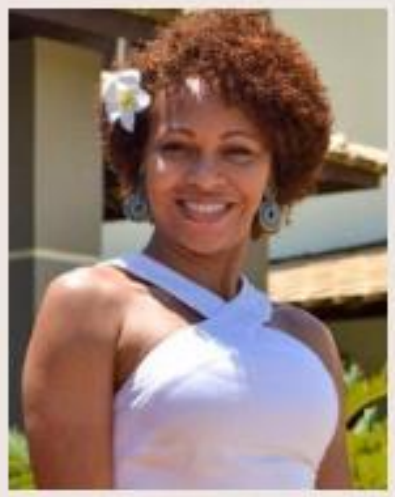

\section{Ana Angélica dos Santos Faro}

Possui curso técnico em química pela Escola Técnica Federal de Sergipe (1996). graduação em Química Licenciatura pela Universidade Federal de Sergipe (2004). mestrado em Engenharia Metalúrgica e de Materiais pela Universidade Federal do Rio de Janeiro/COPPE (2008) e doutorado em Clência e Engenharia de Materiais pela Universidade Federal de Sergipe (2012). Pós-doutorado em Ciência e Engenharia de Materiais pela Universidade Federal de Sergipe (2013). Professora titular e pesquisadora da Faculdade Pio Décimo (2011- atual)

\section{Anna Carla de Jesus Santos}

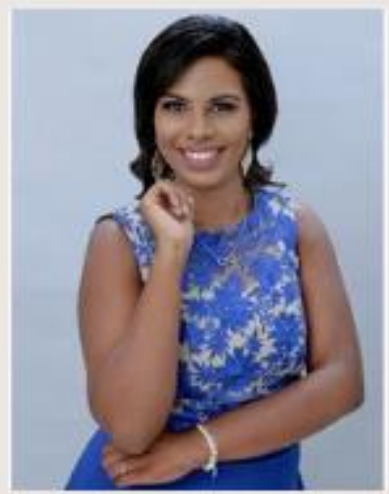

Graduada em Engenharia Civil pela Faculdade Pio Décimo em Aracaju-SE, conclusão no ano de 2018. Técnica em Edificações pelo Instituto Federal de Sergipe IFS, conclusão no ano de 2010. Atuou como profissional técnica na área de projetos da construção civil. Possui experiência de quase 6 anos em projetos da construçấo civil, com ênfase em arquitetura e estrutural de pequeno e médio padrão. Adquiriu conhecimento em estágios nas áreas da construção civil. levantamento cadastral. acompanhamento de obras e projetos em software Eberick. Cype. Revit e Auto CAD. Possui os cursos de Vistorias e Inspeçöes prediais e de Laudo Pericial de engenharia (INBEC).

\section{Neuma Rúbia Figueiredo Santana}

Doutora e Mestre em Desenvolvimento e Meio Ambiente PRODEMA-UFS (2011), especialista em Gestão de Recursos Hidricos-UFBA(2008) e Bióloga (2006). Monitoramento de águas (manguezal, subterrânea e nascentes). relacionados a açōes antrópicas e saúde. Atualmente é integrante do grupo de pesquisa ACQUA-UFS. 


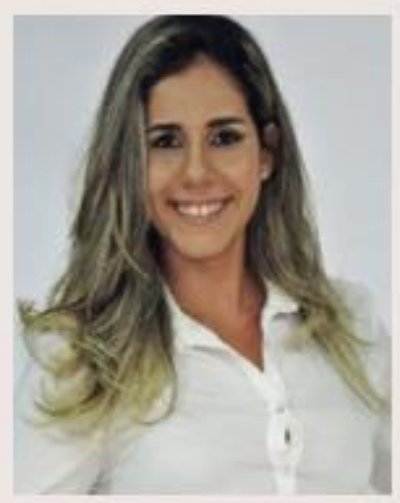

\section{Claryssa de Oliveira Barros}

Graduada em Engenharia Civil pela Faculdade Pio Décimo em Aracaju-SE, conclusão no ano de 2017. Técnica em Edificações pelo Instituto Federal de Sergipe IFS, conclusão no ano de 2013. Atuou como profissional técnica na área da construção civil. Possui experiência de 5 anos em obras. com ênfase no sistema de fabricação e montagem de painéis portantes em concreto armado ( pré-moldados) e obra de alto padräo. Participação efetiva em grupos de prevenção de acidente do trabalho - CIPA. nas empresas, pelas quais passou. Adquíriu conhecimento em estágios nas áreas da construção civil, acompanhamento de obras. levantamento cadastral e atendimento ao público.

\section{Érica de Souza Viana}

Craduada em engenharia civil com experiência em execução e controle de qualidade em serviços de estrutura. alvenaria, instalaçôes, acabamentos cerâmicos, pintura. mármores, entre outros.

\section{Giseli Barbosa de Lima}

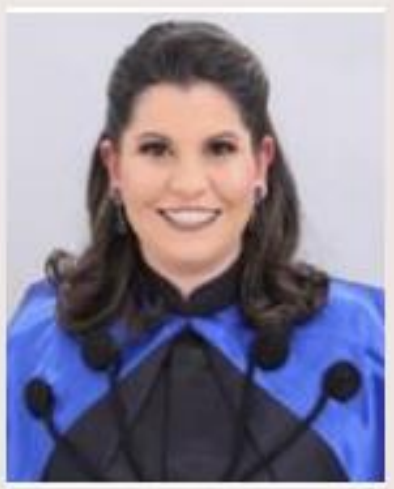

Possui Graduação em Engenharia Civil pela Faculdade Pio Décimo (2013). Especialização em Engenharia de Segurança do Trabalho pela Faculdade Pio Décimo (2015) e Mestrado em Engenharia Civil pela Universidade do Vale do Rio dos Sinos (2017). É Professora da Faculdade Pio Décimo e da UNIRB-Faculdade Serigy no curso de graduação em Engenharia Civil 


\section{Hortência Irys Ribeiro Lúcio}

É graduada em Engenharia Civil pela Faculdade Pio Décimo (2018) e Técnica em Edificações pelo Instituto Federal de Sergipe - IFS (2013). Experiência em levantamentos cadastrais, aprovação de empreendimentos perante os órgãos responsáveis, preparo de contratos, compatibilização de projetos e regularização de imóveis.

\section{Jailton Vieira dos Santos Neto}

Técnico em Edificações-Instituto Federal de Sergipe e graduado em engenharia civil.

\section{Jorge Eduardo Fontes Leite}

Graduado em ADMINISTRAÇÃO (2007), Especialização em Didática e Metodologia do Ensino Superior (2007) pela FACULDADE SÃO LUIS DE FRANÇA (2007) e Especialização em Gestão Acadêmica e Formação Docente (2015) pela FACULDADE PIO DÉCIMO. Atualmente é docente dos Cursos de Pedagogia e Engenharia Civil da FACULDADE PIO DÉCIMO, bem como professor dos cursos de especialização Lato Sensu da referida IES. Atuou como Professor e Administrador - Diretor Comercial do COLÉGIO TÉCNICO HENRIQUE HENNRY, desenvolvendo atividades docentes principalmente relacionadas aos seguintes temas: Metodologia Científica, Tecnologias Assistivas, ABNT, Educação. História, e Diversidade. Atua como Membro do Comitê Editorial da Revista Práxis Pedagógica da FPD 


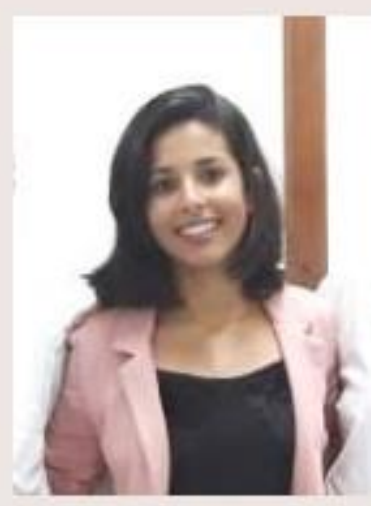

\section{Joyce Helly da Anunciação}

\section{Soares}

Possui graduação em Engenharia Civil pela Faculdade Pio Décimo - Campus I (2018). Mestranda em Desenvolvimento e Meio Ambiente (PRODEMA). Atualmente é do setor administrativo do Instituto de Ensino CP LTDA. Tem experiência na área de Engenharia Civil, com ênfase em Engenharia Civil.

\section{Lana Laís Pereira da Cruz}

Graduada em engenharia civil.

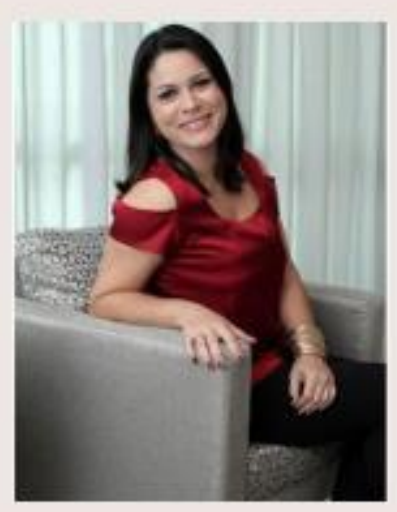

\section{Luciana Gomes Machado Nascimento}

É graduada em Arquitetura e Urbanismo pela Universidade Tiradentes (2001). possui Especialização em Gestão Ambiental pela Faculdade de Negócios de Sergipe FANESE (2006) e Mestrado em Desenvolvimento e Meio Ambiente pelo PRODEMA/UFS - Universidade Federal de Sergipe (2012). Atualmente exerce as funções de Analista Ambiental na Secretaria Municipal do Meio Ambiente e de Professora na graduação dos cursos de Engenharia Cilvil na Faculdade Pio Décimo e Arquitetura e Urbanismo na Faculdade Sergipana - Faser. Dentre as disciplinas que leciona estão: Fundamentos de Arquitetura e Urbanismo. Computaçầo Grăfica. Projeto de Paisagismo. Teoria da Arquitetura e do Urbanismo e Projetos Multifuncionais. 


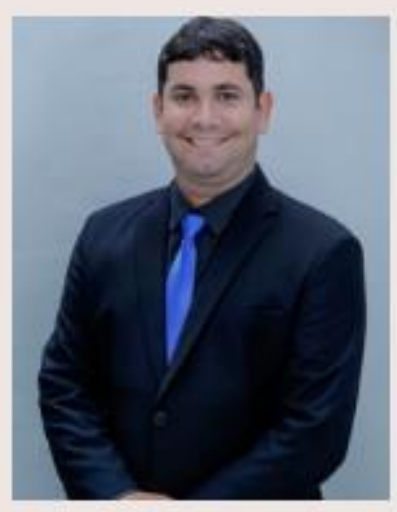

\section{Marcos Moran Oliveira da Silva}

Graduado em Engenharia Civil pela Faculdade Pio Décimo. Aracaju/SE. Possui formação Técnica em Saúde e Segurança do Trabalho pelo SENAI/SE. Atuou como profissional técnico na área da construçăo civil e possui experiência de 12 anos neste setor. Trabalhou em diversos canteiros de obras e edificaçōes verticais do tipo residencial e empresarial. Possui vivência no acompanhamento e execução de obras.

Atualmente atua na área de planejamento e controle de manutenção.

\section{Priscila Conceição de Souza}

Possui formação técnica em Geologia pelo Instituto Federal da Bahia - Campus Salvador/BA (2011) e graduaçăo em Engenharia Civil pela Faculdade Pio Décimo. em Aracaju/SE (2018). Atualmente é Técnica de Exploração de Petróleo Pleno na Petróleo Brasileiro S/A (Petrobras), desde 2012.

\section{Rafaella Lima Correia}

Possui graduação em Engenharia Civil pela Faculdade Pio Décimo - Campus I (2012 - 2018). Técnica em edificaçōes pelo Instituto Federal de Sergipe - Campus Aracaju (2014 2016. 

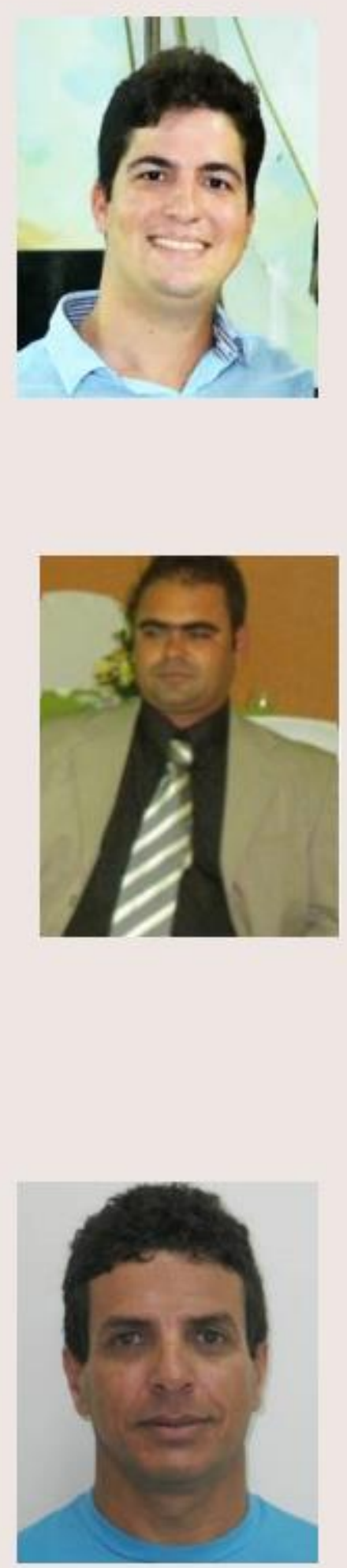

\section{Romário de Jesus Santos}

Possui graduação em Engenharia Civil pela Faculdade Pio Décimo - Campus I (2015) e mestrado em Engenharia de Processos pela Universidade Tiradentes (2018). Atualmente é consultor - VL engenharia e professor titular da Faculdade Pio Décimo - Campus I

\section{Sandro Yuri Valverde Lima da Cruz}

Mestre em Desenvolvimento e Meio Ambiente, UFS: Pós Graduado em Engenharia de Segurança no Trabalho. FPD: Graduado em Engenharia Civil. FPD. Atualmente desempenha a funçäo de Coordenador do Curso de Engenharia Civil da Faculdade Pio Décimo

\section{Silvio Leonardo Valença}

Possui graduação em Engenharia Mecânica pela Universidade Federal da Paraíba (1982), especialização em Engenharia de Segurança do Trabalho, mestrado em Ciência e Engenharia de Materiais pela Universidade Federal de Sergipe (2010) e doutorado em Ciência e Engenharia de Materiais pela Universidade Federal de Sergipe (2014). Atualmente é Engenheiro de Equipamentos Master Petróleo Brasileiro S/A e professor da Faculdade Pio Décimo e Faculdade Estácio/Se. Tem experiência na área de Engenharia Mecânica, com ênfase em Processos de Fabricação, Seleção de Materiais, atuando principalmente nos seguintes temas: resina epóxi, materiais compósitos. gerenciamento de riscos em instalações industriais e Ensaios Mecânicos de Materiais. 


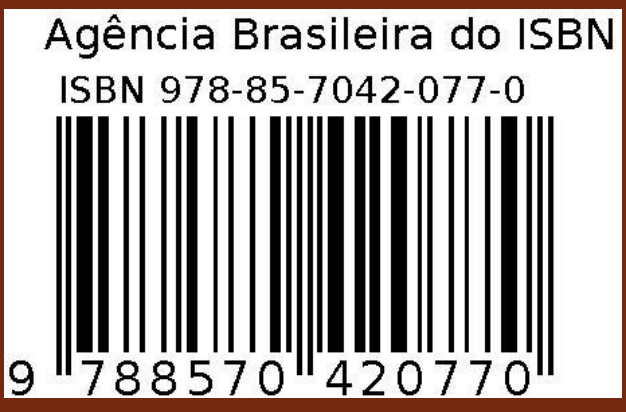

